\title{
FAUUSP

MARIA CELESTE DE FÁTIMA SANCHES

O PROJETO DO INTANGÍVEL NA FORMAÇÃO DE DESIGNERS DE MODA

repensando as estratégias metodológicas para a sintaxe da forma na prática projetual

\section{EL PROYECTO DE LO INTANGIBLE EN LA FORMACIÓN DE DISEÑADORES DE MODA}

repensando las estrategias metodológicas para la sintaxis de la forma en la práctica proyectual 



\section{FAUUSP}

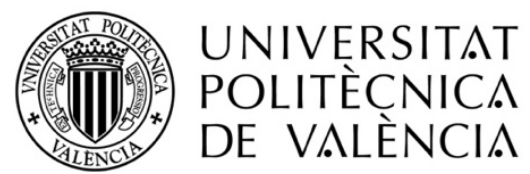

\section{MARIA CELESTE DE FÁTIMA SANCHES}

\section{O PROJETO DO INTANGÍVEL NA FORMAÇÃO DE DESIGNERS DE MODA:}

repensando as estratégias metodológicas para a sintaxe da forma na prática projetual

\section{EL PROYECTO DE LO INTANGIBLE EN LA FORMACIÓN DE DISEÑADORES DE MODA:} repensando las estrategias metodológicas para la sintaxis de la forma en la práctica proyectual

Tese apresentada à Faculdade de Arquitetura e Urbanismo da Universidade de São Paulo e à Universitat Politècnica de València para obtenção do título de Doutor por ambas instituições, conforme Convênio Acadêmico Internacional para Dupla Titulação de Doutorado.

[Tesis presentada en la Faculdade de Arquitetura e Urbanismo da Universidade de São Paulo y en la Universitat Politècnica de València para la obtención del título de Doctor por ambas instituciones, según Convenio Académico Internacional para Doble Titulación de Doctorado].

Orientadores: [directores]

USP: Prof. Dr. Sergio Régis Moreira Martins UPV: Prof. Dr. Bernabé Hernandis Ortuño 
AUTORIZO A REPRODUÇÃO E DIVULGAÇÃO TOTAL OU PARCIAL DESTE TRABALHO, POR QUALQUER MEIO CONVENCIONAL OU ELETRÔNICO, PARA FINS DE ESTUDO E PESQUISA, DESDE QUE CITADA A FONTE.

[AUTORIZO A LA REPRODUCCIÓN Y DIVULGACIÓN TOTAL O PARCIAL DE ESTE TRABAJO, POR CUALQUIER MEDIO CONVENCIONAL O ELECTRÓNICO, PARA FINES DE ESTUDIO E INVESTIGACIÓN, SIEMPRE QUE SEA CITADA LA FUENTE.]

e-mail: tetisanches@hotmail.com

Falta inserir ficha catalográfica aqui 
SANCHES, Maria Celeste de Fátima. O PROJETO DO INTAGÍvEL NA FORMAÇAO DE DESIGNERS DE MODA: repensando as estratégias metodológicas para a sintaxe da forma na prática projetual [EL PROYECTO DE LO INTANGIBLE EN LA FORMACIÓN DE DISEÑADORES DE MODA: repensando las estrategias metodológicas para la sintaxis de la forma en la práctica proyectual]. Tese apresentada à Faculdade de Arquitetura e Urbanismo da Universidade de São Paulo e à Universitat Politècnica de València para obtenção do título de Doutor por ambas as instituições, conforme Convênio Acadêmico Internacional para Dupla Titulação de Doutorado.

Aprovado em:

BANCA EXAMINADORA [TRIBUNAL]

Prof. Dr. Instituição:

Julgamento: Assinatura:

Prof. Dr. Instituição:

Julgamento: Assinatura:

Prof. Dr. Instituição:

Julgamento: Assinatura:

Prof. Dr. Instituição: Assinatura:

Prof. Dr. Instituição: 

Aos meus pais, Odilá e Mauro, responsáveis pelos valores que me trouxeram até aqui. - -

Aos meus alunos, responsáveis pelas descobertas encantadoras que renovam continuamente a minha paixão pela docência. 

Antes de manifestar qualquer gratidão àqueles que contribuíram para que esta pesquisa se concretizasse, gostaria de agradecer a Deus por me conceder a força necessária, por meio do amor que me rodeia, para vencer os obstáculos da trajetória até aqui. Vitórias que atribuem um valor especial à conclusão desta tese. Por isso, meu "MUITO OBRIGADA" a todos que, de algum modo, colaboraram para que isto fosse possível e de modo particular:

aos meus pais e irmãs, pelo acolhimento e amor incondicional;

ao meu companheiro de alma e amado Javier, pela dedicação, parceria, compreensão e amor, você fez muita diferença na caminhada;

aos amigos irmãos, com os quais compartilhei as pedras do caminho, Roger, Ana Luísa e Lília, obrigada por me fazerem acreditar;

à Thassiana Miotto, minha cúmplice de metodologia projetual. As palavras não serão suficientes para lhe agradecer pela amizade, entusiasmo, perspicácia e competência em campo. Seu olhar enriqueceu esta pesquisa e o meu aprendizado;

a todos os alunos que partilharam suas trajetórias comigo, agradeço pelo brilho no olhar, pela espontaneidade e pela inquietação. Meu especial obrigada aos estudantes que participaram diretamente da construção deste estudo, vocês foram a bússola para os meus passos;

às maravilhosas amigas, professoras e colaboradoras, Patrícia de Mello Souza, Lucimar Emídio, Paula Hatadani, Valdirene Nunes, Maria Antônia Romão, Marlene Carlos, Eduarda Veiga, pela generosidade e a multiplicação de olhares nesta investigação.

À Dorotéia (in memoriam), grande amiga e incentivadora, por compartilhar o caminho e me mostrar o encanto dos pequenos passos;

aos meus orientadores, Prof. Dr. Sérgio Regis Moreira Martins (Serginho) e Prof. Dr. Bernabé Hernandis Ortuño (Berna), por confiarem em meu trabalho, pelo aprendizado na construção desta pesquisa e, principalmente, pela generosidade e carinho;

ao Departamento de Design da UEL, à secretária Rose Oliveira, aos professores e amigos valiosos que me acolheram e apoiaram meu crescimento profissional e pessoal. Sou imensamente grata pelo precioso suporte para as ações em campo, pela disponibilidade irrestrita e pela confiança depositada nesta pesquisa;

à FAU-USP e à UPV, pelo tempo e trabalho investidos na efetivação da parceria que amparou o desenvolvimento deste estudo, especialmente aos queridos Javier Martinez, Cristina Lafasse e Ivani Sokoloff pela paciência e amabilidade. 



\section{RESUMO}

SANCHES, Maria Celeste de Fátima. O PROJETO DO INTAGÍvEL NA FORMAÇÃO DE DESIGNERS DE MODA: repensando as estratégias metodológicas para a sintaxe da forma na prática projetual [EL PROYECTO DE LO INTANGIBLE EN LA FORMACIÓN DE DISEÑADORES DE MODA: repensando las estrategias metodológicas para la sintaxis de la forma en la práctica proyectual]. 2016. 268 f. Tese (Doutorado)- Faculdade de Arquitetura e Urbanismo da Universidade de São Paulo / Universitat Politècnica de València

O vestuário de moda cumpre um importante papel na interface entre o ser humano e o seu entorno, participando ativamente da adaptação física ao ambiente e da mediação de expressões individuais e representações sociais. A interação se efetiva por meio da conexão espacial entre o corpo, o artefato e o contexto, na qual a configuração da veste constitui um espaço de vivências sensoriais que fomenta processos de identificação e transferência de significados. Essa atuação comunicativa enfatiza o vínculo entre a composição formal (sintaxe da forma) e o conteúdo expressivo como quesito essencial no planejamento deste tipo de produto. Deste modo, esta pesquisa visou a investigação de estratégias metodológicas para a articulação entre a ordenação configurativa (dimensão sintática) e o conteúdo informacional (dimensão semântica) no projeto de design de moda. Especificamente, aplicou-se a identificar estratégias para decodificação/codificação de referenciais expressivos na composição estético-formal do vestuário de moda, propondo um instrumental destinado a facilitar o direcionamento expressivo e a geração de possibilidades formais nas práticas projetuais de estudantes de Design de Moda. A natureza da pesquisa foi qualitativa e a estratégia usada foi a investigação-ação. Os procedimentos metodológicos incluíram estudos bibliográficos, documentais e intervenções em campo no Curso de Design de Moda da Universidade Estadual de Londrina. A avaliação dos resultados se deu pela triangulação dos dados recolhidos por meio de observação participante, depoimentos individuais e realização de focus group. Deste modo, foi possível a redução e classificação das informações e, posteriormente, $\mathrm{o}$ balizamento com os conceitos teóricos. Para consolidar o instrumental proposto foram implicados conteúdos teóricos e práticos dos campos do design, da moda, da comunicação e da pedagogia, relacionados transversalmente nas abordagens acerca de metodologia do projeto, pensamento sistêmico, pensamento visual e sintaxe da forma. Os resultados procedentes dos processos avaliativos evidenciaram um progresso na capacidade de delimitar e gerar a organização sintática do vestuário de moda, confirmando a hipótese de que a gestão sistêmica da informação, assistida pelo pensamento visual, facilita a síntese de conceitos expressivos e a percepção das estruturas compositivas para a experimentação da sintaxe da forma. Sob o rumo da aprendizagem significativa, da gestão sistêmica do projeto e do pensamento visual, acredita-se ter avançado na busca por melhores práticas educacionais para o desenvolvimento do raciocínio projetual entre estudantes de design de moda, contribuindo para a ampliação do conhecimento a respeito das metodologias de projeto neste campo.

Palavras-chave: design de moda; projeto; ensino; metodologia; sintaxe da forma. 

El vestuario de moda cumple un importante papel en el interfaz entre el ser humano y su entorno, siendo partícipe activo de la adaptación física al medio ambiente y del intercambio de expresiones individuales y representaciones sociales. Esta interacción se hace efectiva mediante la conexión espacial entre el cuerpo, el artefacto y el contexto, en la cual la configuración del vestuario constituye un espacio de vivencias sensoriales que fomenta la existencia de procesos de identificación y transferencia de significados. Esta actuación comunicativa enfatiza el vínculo entre la composición formal (sintaxis de la forma) y el contenido expresivo, como razón de ser en el planeamiento del vestuario de moda. De esta forma, la investigación se ha dirigido al estudio de estrategias metodológicas con objeto de mejorar la articulación entre la ordenación configurativa (dimensión sintáctica) y el contenido de información (dimensión semántica) en el proyecto de diseño de moda. Concretamente se ha centrado en la identificación de estrategias para la codificación y decodificación de referenciales expresivos en la composición estético formal del vestuario de moda, proponiendo instrumentos destinados a facilitar el direccionamiento expresivo y la generación de posibilidades formales, en las prácticas del proyecto de los estudiantes de Diseño de Moda. La investigación ha sido de naturaleza cualitativa. La estrategia usada ha sido de investigación-acción. Los procedimientos metodológicos utilizados han incluido estudios bibliográficos, documentales e intervenciones en campo en el Grado de Diseño de Moda de la Universidade Estadual de Londrina. La evaluación de los resultados se ha realizado mediante la triangulación de datos recogidos en el desarrollo de la observación participante, testimonios individuales y realización de focus group. Con ello, se ha posibilitado la reducción y clasificación de la información y, posteriormente, el señalamiento de referencias con los conceptos teóricos. Al objeto de consolidar el instrumental propuesto, se han utilizado contenidos teóricos y prácticos de los campos del diseño, la moda, la comunicación y la pedagogía. Todos ellos se han adoptado como referencial teórico, de forma conjunta y transversal, para los abordajes que integran la metodología de proyecto, el pensamiento sistémico, el pensamiento visual y la sintaxis de la forma. Los resultados obtenidos en los procesos de evaluación han evidenciado un avance en la capacidad para delimitar y generar la organización sintáctica del vestuario de moda, confirmando la hipótesis de que la gestión sistémica de la información, apoyada por el pensamiento visual, facilita la sintaxis de los conceptos expresivos y la percepción de las estructuras compositivas para la experimentación de la sintaxis de la forma. En el camino del aprendizaje significativo, de la gestión sistémica del proyecto y del pensamiento visual, se confía en haber avanzado en la búsqueda de mejores prácticas educacionales para el desarrollo del razonamiento de proyecto entre estudiantes de diseño de moda, contribuyendo a la ampliación del conocimiento relativo a las metodologías de proyecto en este campo.

Palabras clave: diseño de moda, proyecto, enseñanza, metodología, sintaxis de la forma. 

Fashion clothing plays an important part in the interface between humans and their environment, actively participating in the physical adaptation to the environment and the mediation of individual expressions and social representations. The interaction occurs by the spatial connection between the body, the artifact and the context, in which the configuration of the clothing constitutes a space of sensory experiences that promotes identification processes and transfer of meanings. This communicative action emphasizes the bond between the formal composition (syntax of the form) and the expressive content as an essential issue in the planning of this type of product. Therefore, this research aimed to investigate the methodological strategies for the articulation between the configurative ordination (syntactic dimension) and the informational content (semantic dimension) in the fashion design project. Specifically, it was applied strategies for decoding / encoding expressive references which were identified in the aesthetic and formal composition of fashion clothing, proposing an instrument destined to facilitate the expressive orientation and the generation of formal possibilities in projective practices of Fashion Design students. The nature of this research was qualitative and a research-action strategy was applied. The methodological proceedings included bibliographical studies, documental and field interventions in the Fashion Design course at the State University of Londrina. The results evaluation was realized by means of the triangulation of data collected through participant observation, testimonies and focus group, allowing the reduction and classification of information and subsequently by putting it in accordance with the theoretical concepts. To consolidate the proposed instrument, it was implied theoretical and practical contents of the field of design, fashion, communication and pedagogy. They have been considered as theory references, transversely applied and taken as a whole, with the approaches on design methodology, systemic thinking, visual thinking and syntax of the form. The results from the evaluation processes made evident an improvement in the ability to delimitate and generate the syntactic organization of fashion clothing, confirming the hypothesis that the systemic information management, assisted by visual thinking, facilitates the synthesis of expressive concepts and the perception of compositional structures for the experimentation of the form syntax. Upon the direction of a meaningful learning, of a systemic project and visual thinking management, it is credible to affirm that this has made advances in the search for better educational practices for the development of design thinking amongst fashion design students, therefore making contributions to the expansion of knowledge about the design methodologies in this field.

Keywords: fashion design; project; teaching; methodology; syntax of the form. 

El vestuari de moda compleix un important paper en la interfície entre l'ésser humà i el seu entorn, sent partícip actiu de l'adaptació física al medi ambient i de l'intercanvi d'expressions individuals i representacions socials. Aquesta interacció es fa efectiva mitjançant la connexió espacial entre el cos, l'artefacte i el context, en la qual la configuració del vestuari constitueix un espai de vivències sensorials que fomenta l'existència de processos d'identificació i transferència de significats. Aquesta actuació comunicativa emfatitza el vincle entre la composició formal (sintaxi de la forma) i el contingut expressiu com a raó de ser en el planejament de vestuari de moda. D'aquesta forma, la recerca s'ha dirigit a l'estudi d'estratègies metodològiques per a l'articulació entre l'ordenació configurativa (dimensió sintàctica) i el contingut d'informació (dimensió semàntica) en el projecte de disseny de moda. Més especificament, s'ha centrat en la identificació d'estratègies per a la codificació i descodificació de referencials expressius en la composició estètic formal del vestuari de moda, proposant un instrumental destinat a facilitar l'adreçament expressiu i la generació de possibilitats formals en les pràctiques de projecte dels estudiants de Disseny de Moda. La recerca ha sigut de naturalesa qualitativa. L'estratègia usada ha sigut de la recerca-acció. Els procediments metodològics han inclòs estudis bibliogràfics, documentals i intervencions en camp en el Grau de Disseny de Moda de la Universidade Estadual de Londrina. L'avaluació dels resultats s'ha realitzat mitjançant la triangulació de dades arreplegades en el desenvolupament de l'observació participant, testimoniatges individuals $i$ realització de focus group. Amb açò, s'ha possibilitat la reducció i classificació de la informació i, posteriorment, l'assenyalament de referències amb els conceptes teòrics. A fi de consolidar l'instrumental proposat, s'han utilitzat continguts teòrics i pràctics dels camps del disseny, la moda, la comunicació i la pedagogia. Tots ells s'han adoptat com a referencial teòric, de forma conjunta i transversal, per als abordatges que integren la metodologia de projecte, el pensament sistèmic, el pensament visual i la sintaxi de la forma. Els resultats obtinguts en els processos d'avaluació han evidenciat un avanç en la capacitat per a delimitar i generar l'organització sintàctica del vestuari de moda, confirmant la hipòtesi que la gestió sistèmica de la informació, recolzada pel pensament visual, facilita la sintaxi dels conceptes expressius $i$ la percepció de les estructures compositives per a l'experimentació de la sintaxi de la forma. En el camí de l'aprenentatge significatiu, de la gestió sistèmica del projecte i del pensament visual, es confia a haver-hi avançat en la cerca de millors pràctiques educacionals per al desenvolupament del raonament de projecte entre estudiants de disseny de moda, contribuint a l'ampliació del coneixement relatiu a les metodologies de projecte en aquest camp.

Paraules clau: disseny de moda, projecte, ensenyament, metodologia, sintaxi de la forma. 



\section{LISTA DE FIGURAS}

Figura 1- Estrutura Básica do Curso de Design de Moda da UEL.................................23

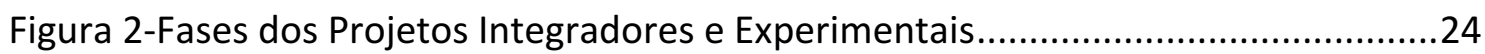

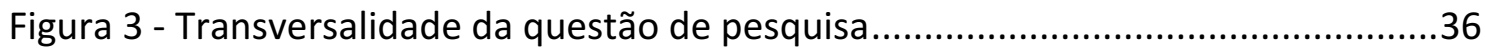

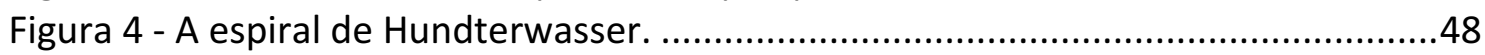

Figura 5 - Exemplo ilustrativo das quatro dimensões semióticas do produto. ..............54

Figura 6 - A rede cíclica de paradigmas e sintagmas produzidos no sistema de moda .57

Figura 7 - Fluxo de informação e síntese na fase de preparação ................................70

Figura 8 - Exemplo do conjunto das relações de sintaxe visual .....................................84

Figura 9 - Anatomia da mensagem visual no vestuário de moda ................................85

Figura 10 - Estrutura esquemática do pensamento projetual ....................................96

Figura 11 - Exemplo de decodificação de referência estética em um painel semântico

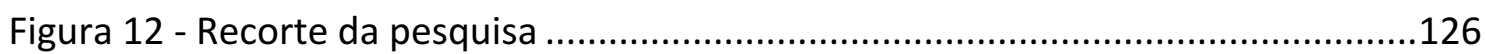

Figura 13 - Representação em quatro fases do ciclo básico da investigação-ação.......129

Figura 14 - Panorama de técnicas e procedimentos da pesquisa ..............................131

Figura 15 - Sobre a existência de uma sequência para as ações elencadas ...................149

Figura 16 - Principais dificuldades apontadas pelos estudantes .................................151

Figura 17 - Dificuldades listadas em ordem de relevância decrescente de 1 a 3.........151

Figura 18 - Convergência dos direcionadores para interação em campo ...................153

Figura 19 - Mapa de conexões dos campos de conhecimento ...................................154

Figura 20 - Fluxo de informações entre os agentes influenciadores do Design de Moda

Figura 21 - Delimitadores da forma a partir das variáveis do contexto ......................159

Figura 22 - Conjunto de Influências atuantes na sintaxe formal/visual. ......................160

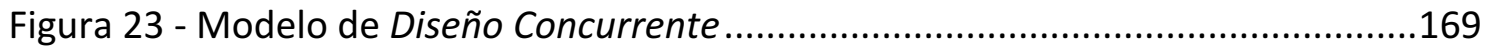

Figura 24 - Processo de desenvolvimento de novos Produtos (em aprendizagem

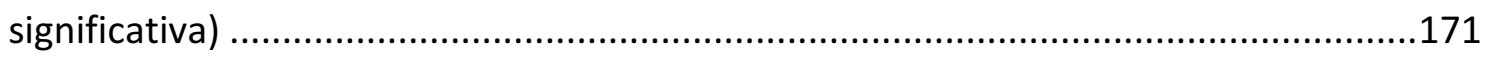

Figura 25 - Exemplo de Mapa de Categorias Expressivas..........................................180

Figura 26 - Diagrama Radial de Exploração Contextual (Diagrama REC) ......................182

Figura 27 - Exemplo ilustrativo de uso do Diagrama REC ...........................................183

Figura 28 - Alunos em interação com o Mapa de Categorias Expressivas ....................187

Figura 29 - Alunas em interação com o Diagrama REC em pré-teste...........................189

Figura 30- Experimentações de sintaxe da forma .....................................................189

Figura 31 - Alunos em interação com Diagrama REC e Mapa de Categorias Expressivas

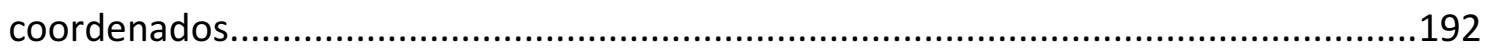

Figura 32 - Estudo do espaço de design sobre representação do corpo......................192

Figura 33 - Conexões das estratégias metodológicas na Interação 3 ...........................193

Figura 34 - Exemplo 1: documentação de projeto- Mapa de Categorias Expressivas e

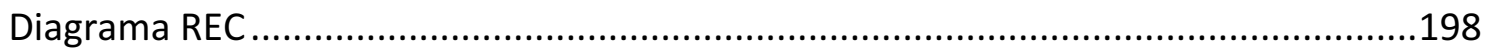

Figura 35 - Exemplo 1: estudos de sintaxe da forma em interação corporal ...............198

Figura 36 - Exemplo 1: protótipo do Acommodare e produto final produzido pela

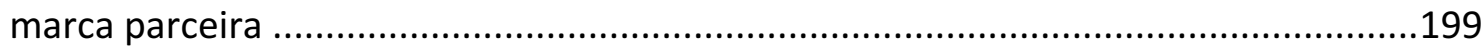

Figura 37-Exemplo 2: documentação de projeto - Mapa de Categorias Expressivas e Diagrama REC. 

Figura 38 - Exemplo 2: estudos do "espaço de design" sobre o corpo e comportamento

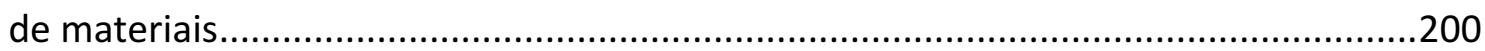
Figura 39 - Exemplo 2: produto final produzido pela marca parceira e protótipo da

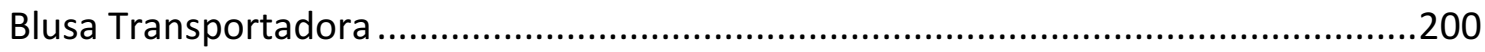

Figura 40 - Exemplo 3: registros do processo de evolução da sintaxe da forma .........200 Figura 41 - Exemplo 3: documentação de projeto - Mapa de Categorias Expressivas e

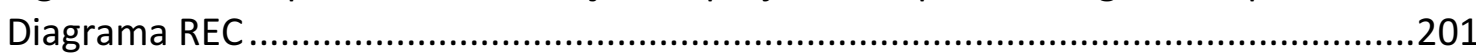

Figura 42 - Exemplo 3: protótipo do Ninho Vestível ...................................................201

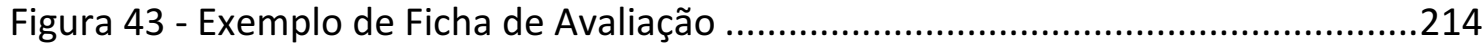

Figura 44 - Índice geral de alcance dos objetivos por grupo ......................................215

Figura 45 - Índice de alcance dos objetivos por cada professor avaliador ....................216

Figura 46 - Formato definitivo das ferramentas propostas em interação ...................226 



\section{LISTA DE QUADROS}

Quadro 1 - Contribuições dos Eixos de Conhecimento no Curso de Design de Moda da UEL.

Quadro 2-Delimitação atual das atividades integradoras .........................................26

Quadro 3 - Preocupações com a ergonomia no consumo (processo de uso) ..................63

Quadro 4-Resumo dos conceitos sobre as unidades visuais ....................................82

Quadro 5 - Percurso do desenvolvimento do raciocínio de composição visual ............136

Quadro 6 - Ferramentas de síntese visual/gráfica na configuração de produtos de

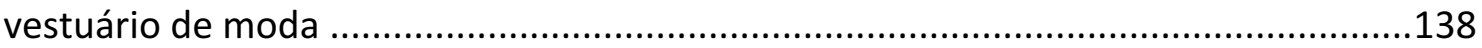

Quadro 7 - Níveis de interação na experiência de uso do vestuário de moda..............141

Quadro 8 - Análise focus group - Grupo 1 (3a série) .............................................145

Quadro 9 - Análise focus group - Grupo 2 (2a série) .................................................146

Quadro 10 - Resultados da análise de conteúdo- principais ações projetuais .............148

Quadro 11 - Conexão entre os focos das ações projetuais e habilidades

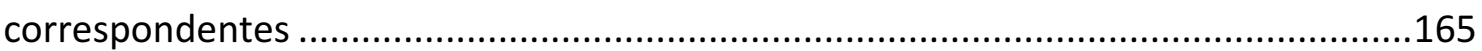

Quadro 12 - Pontos chave do posicionamento didático-pedagógico .........................173

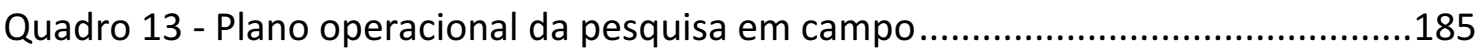

Quadro 14 - Especificação da Primeira Interação em Campo .......................................186

Quadro 15 - Especificação da Segunda Interação em Campo .....................................188

Quadro 16 - Especificação da terceira interação em campo......................................191

Quadro 17 - Síntese das observações em campo ......................................................203

Quadro 18 - Correlações entre dificuldades diagnosticadas e contribuições citadas

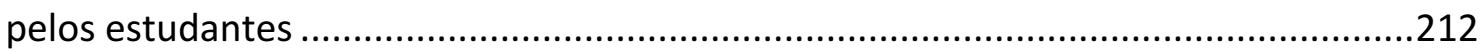

Quadro 19 - Síntese dos resultados do focus group com os pares ............................219 



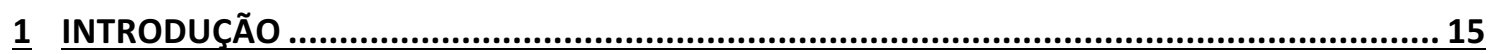

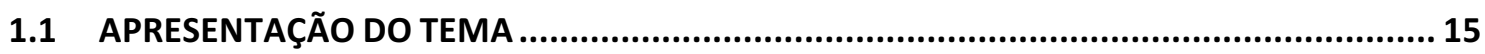

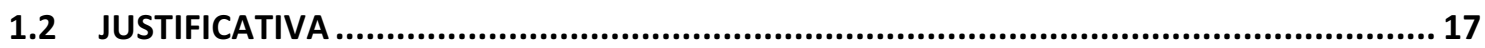

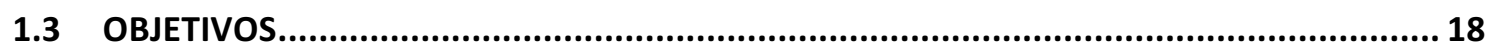

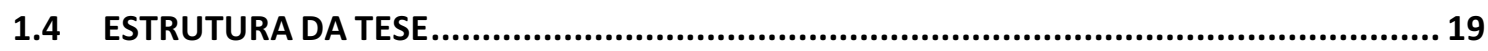

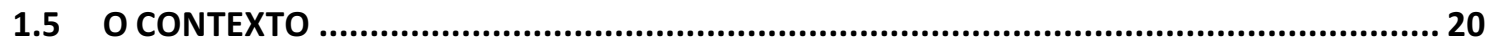

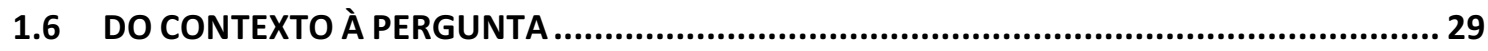

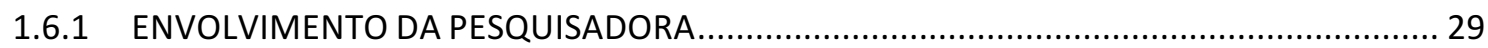

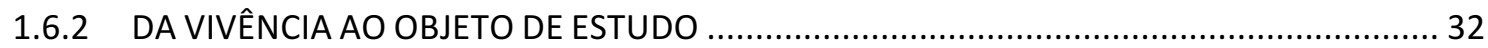

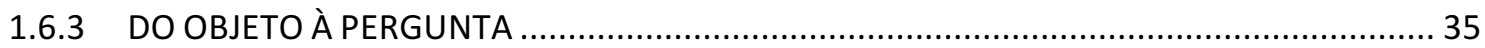

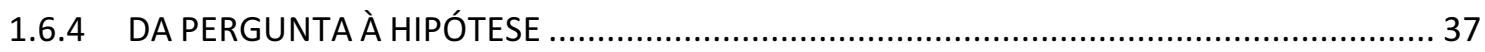

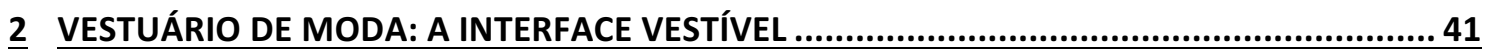

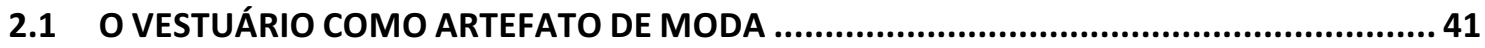

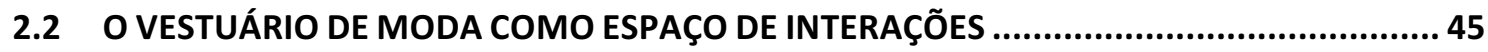

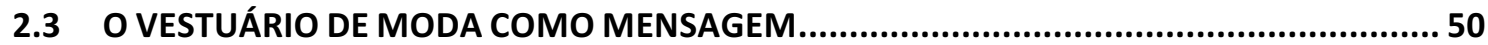

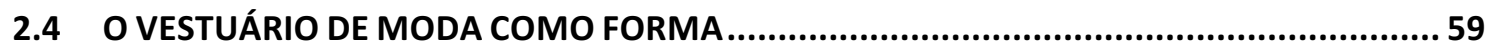

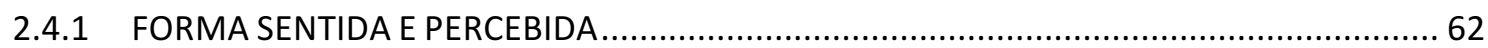

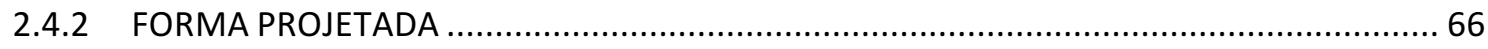

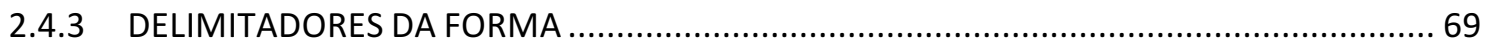

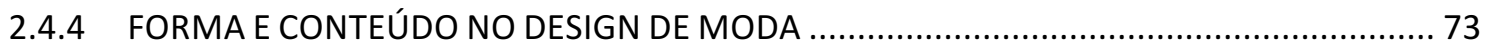

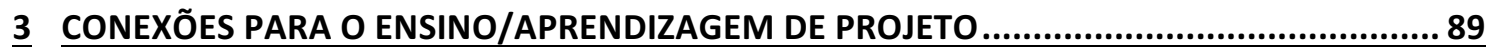

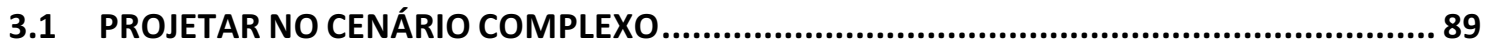

3.2 OS PROCESSOS DO PENSAMENTO PROJETUAL ..............................................................94

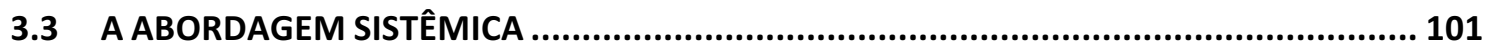

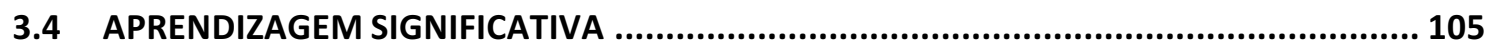

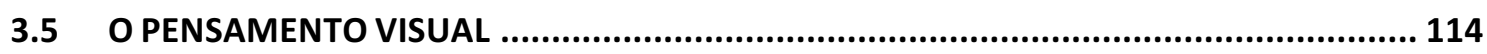

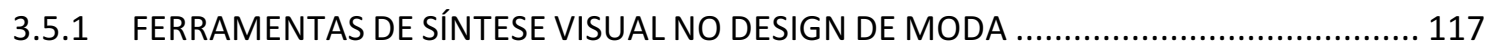

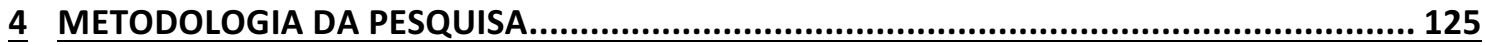

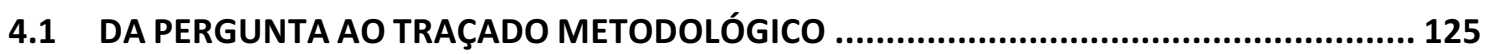

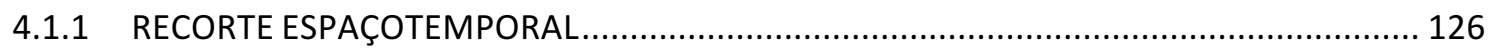

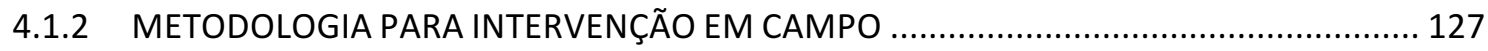

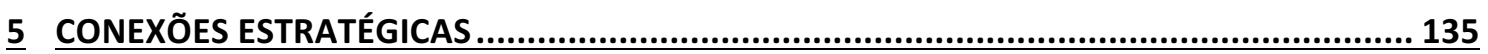

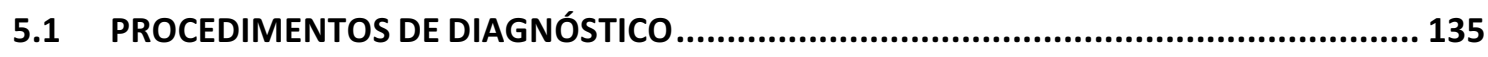

5.1.1 FERRAMENTAS DE SÍNTESE VISUAL/FORMAL NO UNIVERSO ESTUDADO ..................... 135

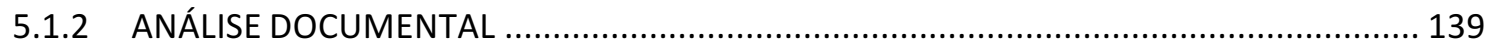

5.1.3 OPINIÃO DOS SUJEITOS PARTICIPANTES

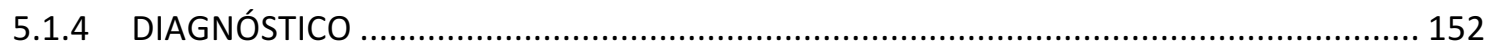

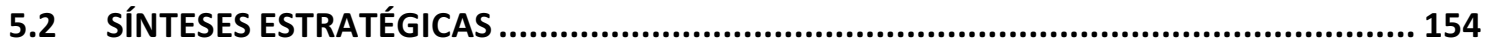

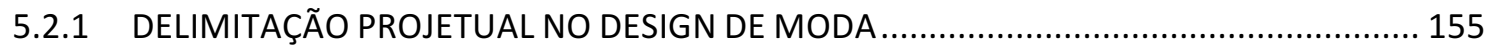

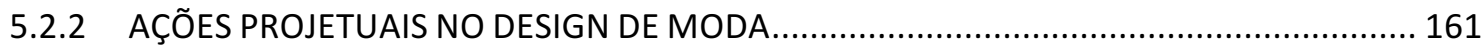

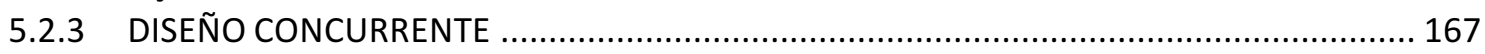





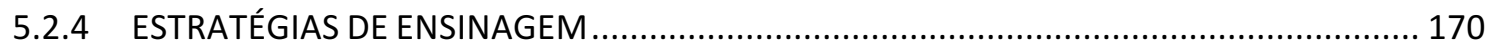

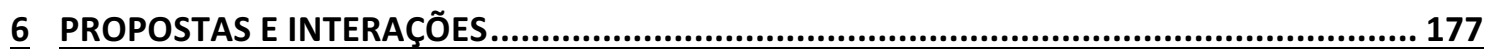

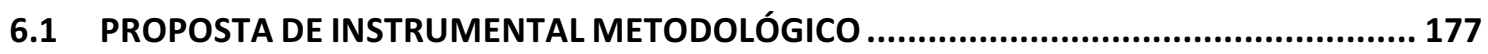

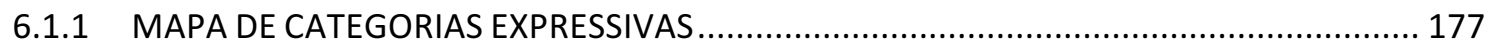

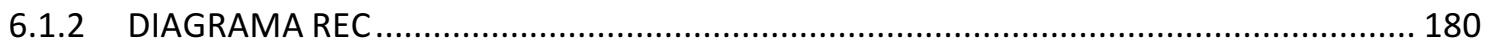

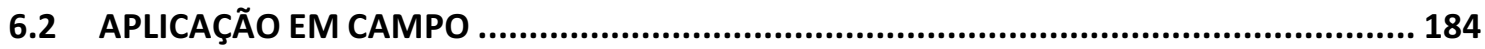

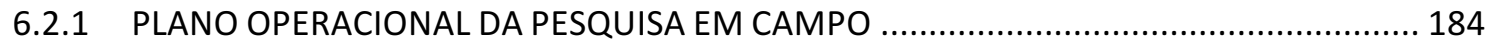

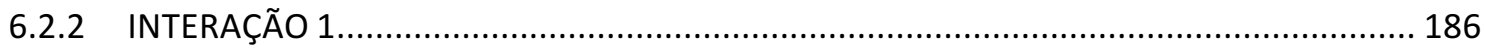

6.2.3 INTERAÇÃO 2

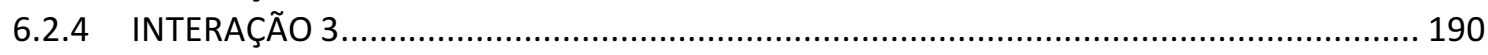

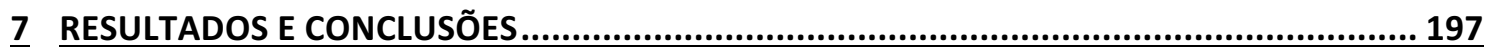

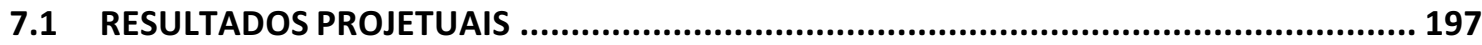

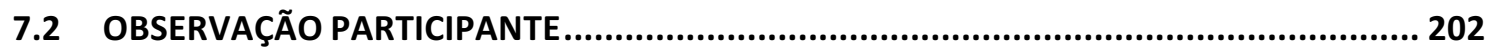

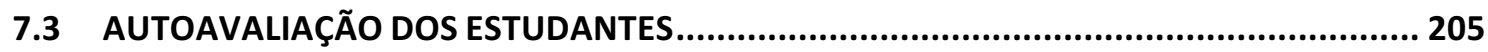

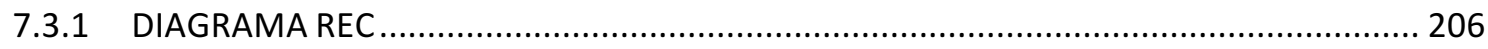

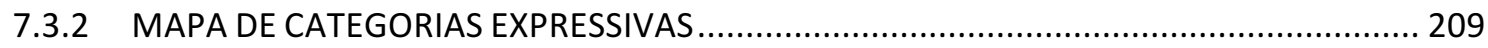

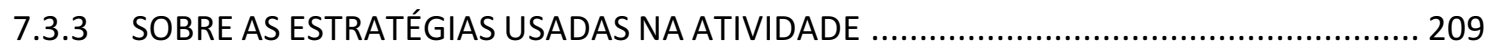

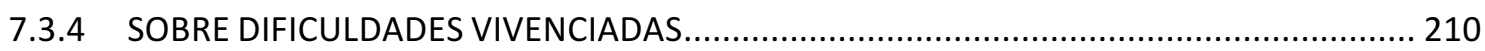

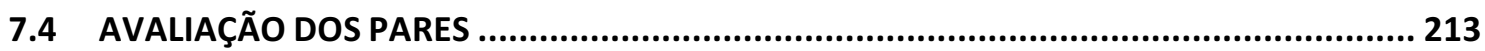

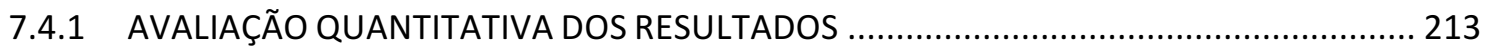

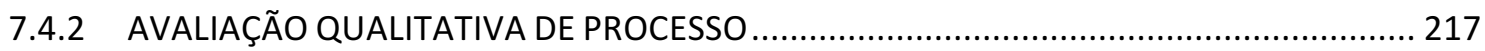

7.5 TRIANGULAÇÃO DOS DADOS E VALIDAÇÃO DO INSTRUMENTAL PROPOSTO ............... 224

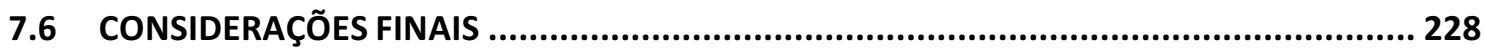

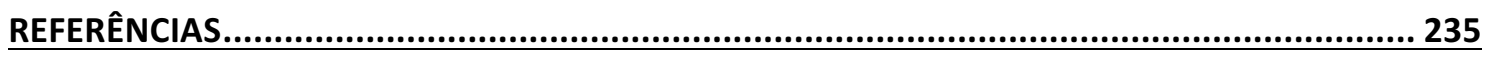

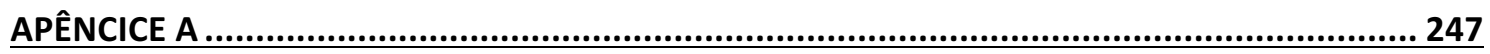

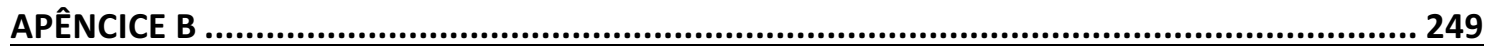

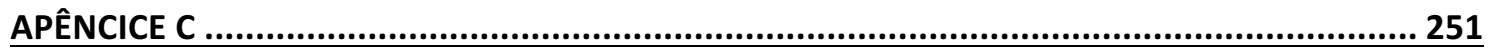



CAPÍTULO 1

-

Sobre indagações e diretrizes 



\section{INTRODUÇÃO}

\subsection{APRESENTAÇÃO DO TEMA}

A atribuição de valor a um artefato depende, principalmente, da avaliação subjetiva do seu desempenho na experiência de uso. O usuário o estimará positivamente à proporção que este artefato instaure sentidos em seu cotidiano, sobretudo quando se examina o vestuário de moda, no qual o valor simbólico, na maioria das vezes, sobrepõese ao seu valor utilitário básico de proteger o corpo.

Na experiência de uso, o vestuário de moda constitui a interface entre corpo e contexto, na qual os vínculos estabelecidos podem ser muito estreitos e imediatos. Em uma relação simbiótica, a veste se incorpora ao sujeito, como segunda pele, e participa das trocas com o entorno, em nível individual e coletivo. Neste rumo, pode-se situar a vestimenta como o primeiro espaço habitado pelo corpo/indivíduo, o qual adentra outros envoltórios espaciais, evidenciando um encadeamento sucessivo de espaços habitados, em que a vestimenta atua como meio de adaptação física, expressão individual e representação social.

Castilho (2004) e Oliveira $(2005 ; 2007 ; 2011)$ enfatizam um processo de significações gerado nestas vinculações. Desta perspectiva, o vestuário de moda é percebido como portador de informações que, atreladas à linguagem corporal, criam um enunciado conexo. Assim, o sujeito se entrelaça a sua segunda pele e, acoplados, interagem em espaços diversificados, onde transitam outros corpos vestidos, constituindo uma malha comunicativa que promove um movimento recíproco de transformação entre "corpo habitante" e "espaço habitado" (SOUZA, 2008; SALTZMAN 2008).

Estas interfaces vestíveis se convertem em um meio de vivências sensoriais que estimulam a produção de sentidos. Logo, a configuração do vestuário de moda compreende um composto material/estético/informacional que é experimentado em múltiplas dimensões e percebido como mensagem não verbal.

Para projetar o vestuário de moda, sob esta perspectiva de interface vestível, é fundamental ter em conta que os delimitadores da sua forma são construídos em um 
sistema de relações em que estão incluídos: possibilidades materiais e tecnológicas; estruturas corpórea e perceptiva humanas; conteúdos expressivos referentes a um determinado contexto sociocultural.

Sob esta linha de raciocínio, esta investigação parte do pressuposto de que a configuração do vestuário de moda é um canal comunicativo e, para que esse canal seja efetivo, é relevante pensar em meios coerentes para organizar os elementos que o compõem. Isso implica em aceitar também o pressuposto de que a combinação ordenada de elementos como formato, cores e texturas pode estabelecer um sistema de signos. Sobre esta plataforma, é pertinente inferir que há um raciocínio de "sintaxe" para relacionar esses elementos em códigos reconhecíveis, dando forma ao conteúdo expressivo.

Por este ângulo, a expressão "projeto do intangível", que intitula esta tese, sintetiza essa concepção de que a forma proporciona o meio sensorial (tangível) para a construção de sentidos, articulando os vínculos subjetivos com o artefato e gerando comunicação, sua derivação intangível, que no caso do vestuário de moda é, reconhecidamente, essencial.

As ponderações acerca da valorização da experiência afetiva e de fatores intangíveis nos novos cenários são pontos cruciais para as diretrizes do design contemporâneo. Estes aspectos são especialmente relevantes quando se discute o desenvolvimento de produtos dotados de conteúdo de moda, nos quais a subjetividade e a renovação são premissas básicas.

Assim sendo, esta pesquisa enfocou como objeto de estudo o instrumental metodológico para auxiliar a sintaxe formal/visual no projeto de vestuário de moda, direcionado ao âmbito educacional. Para tanto, foi conduzida sob uma abordagem qualitativa e multidisciplinar, integrando conteúdos das áreas de comunicação, design e pedagogia. Destes conteúdos, foram assimiladas como principais diretrizes a premissa da gestão sistêmica do processo projetual, os parâmetros construtivistas da aprendizagem significativa e as vantagens das sínteses visuais como estratégia de organização do pensamento.

As percepções de dezesseis anos de prática docente no ensino de metodologia projetual na formação de designers de moda e a disponibilidade de um ambiente propício ao estudo em campo propiciaram uma pesquisa de cunho teórico-empírico, por 
meio de investigação-ação, culminando na proposição de um instrumental metodológico inédito, destinado a facilitar a delimitação projetual e a geração da sintaxe da forma.

\subsection{JUSTIFICATIVA}

As contribuições desta pesquisa alcançam, primeiramente, o ambiente acadêmico do Bacharelado em Design de Moda da Universidade Estadual de Londrina, onde os efeitos práticos da intervenção em campo já demostraram transformações positivas na formação projetual dos estudantes e o instrumental metodológico foi ampliado com a assimilação de novas ferramentas de projeto.

No entanto, os benefícios potenciais podem se estender a outros contextos, aportando contribuições sociais, práticas e teóricas. Nesta direção, a maior colaboração extramuros seria no âmbito da educação superior do Design de Moda.

De acordo com os dados divulgados pelo Ministério da Educação, o Brasil conta com 157 cursos superiores credenciados e ativos com a denominação Design de Moda (MEC, 2015), indicando uma grande atividade educacional dedicada à formação de profissionais para atuar no campo projetual ou em áreas correlacionadas ao planejamento de produtos, serviços e comunicação no campo da moda. Contudo, apesar do grande número de cursos superiores nesta área, é um domínio de conhecimentos muito recente na academia. A concepção de produtos de moda, sob a ótica do design, é ainda mais jovem, haja vista que as Diretrizes Curriculares Nacionais do Curso de Graduação em Design foram aprovadas no ano de 2004. Logo, é pertinente deduzir que existe um amplo universo de formação de profissionais, em que há uma grande probabilidade de existência de lacunas de conhecimento dirigido. Portanto, pesquisas que tratem do ensino/aprendizagem de projeto no âmbito específico da moda podem contribuir com aportes teóricos para a fundamentação da prática docente.

Em relação às contribuições práticas, os resultados da aplicação em campo podem ser propulsores de outros estudos acerca de métodos sistêmicos ou de estratégias para a articulação das dimensões sintática e semântica no projeto do vestuário de moda. 
Igualmente, além das contribuições práticas no campo educacional, a pesquisa pode propiciar implicações no mundo corporativo, por meio dos sujeitos participantes do estudo, uma vez que o instrumental continua em uso no ambiente estudado e os estudantes colaboradores entrarão em estágio de imersão no ano de 2017. Logo, é possível que se amplie o número de futuros profissionais capazes de levar potenciais contribuições deste ambiente às empresas em que vão atuar.

Neste rumo, vale destacar que a heterogeneidade de culturas organizacionais que regem as empresas de moda no Brasil origina cenários extremamente diversificados e, muitas vezes, ainda resistentes à atuação de designer de moda. Por isso, a incorporação do design nestas empresas será facilitada, ou ampliada, se a formação desses profissionais refinar a sua competência para investigar, gerenciar e conectar variáveis, sob métodos sistêmicos e flexíveis, que permitam a síntese de critérios coerentes a cada contexto projetual. Por outra parte, a habilidade para decodificar/codificar referenciais expressivos na sintaxe da forma do artefato é fundamental para a inovação na indústria do vestuário de moda, já que a experiência estético-simbólica é o canal mais forte entre usuários e produtos de moda.

\subsection{OBJETIVOS}

Objetivo Geral: Estudar o instrumental metodológico destinado à articulação das dimensões sintática e semântica na configuração do vestuário de moda, para aplicação no âmbito educacional do Design de Moda.

\section{Objetivos Específicos:}

- investigar estratégias metodológicas para o ensino/aprendizagem de projeto em Design de Moda;

- identificar estratégias de projeto para a decodificação/codificação de referenciais expressivos na composição estético-formal do vestuário de moda;

- propor estratégias metodológicas que auxiliem o processo de síntese de códigos expressivos e impulsionem a geração da sintaxe da forma nas práticas projetuais de estudantes de Design de Moda; 
- avaliar, por meio da ação/observação em campo, a eficácia das estratégias propostas como facilitadoras da sintaxe da forma, no percurso projetual de alunos de Design de Moda da Universidade Estadual de Londrina (UEL).

\subsection{ESTRUTURA DA TESE}

A estrutura da tese foi organizada sob a mesma diretriz de encadeamento que guiou a pesquisa, a qual partiu do conhecimento do universo estudado, seguindo para a construção de bases teóricas, definição de estratégias para interação em campo, registro das ações e desdobramentos em campo, apresentação e discussão dos resultados projetuais e avaliativos, validação e considerações finais.

Sob esta linha de raciocínio, o primeiro capítulo aborda aspectos introdutórios, expondo o contexto em que se insere a pesquisa, com o intuito de esclarecer as motivações, a delimitação do objeto e os objetivos da investigação.

No segundo capítulo foram reunidas as conexões teóricas que fundamentaram as decisões estratégicas para a ação no universo estudado. Nesta direção, a explanação aborda primeiro a contextualização sociocultural, em que a moda emerge como fenômeno cultural, para então focalizar o vestuário neste sistema. Neste rumo, pinçase, entre os diversos modos de interação que envolvem o vestuário de moda, o seu aspecto comunicativo, analisando-o como mediador de mensagens por meio de sua composição formal.

A partir da demarcação de um atributo a ser estudado, foi possível adentrar as conjecturas sobre o projeto deste tipo de artefato. Para tanto, apresenta-se uma visão panorâmica sobre o processo de design no campo da moda, com o intuito de centrar as análises na delimitação projetual e nas variáveis que interferem na sintaxe da forma do vestuário de moda.

Complementando as bases teóricas, o terceiro capítulo reúne a plataforma de fundamentos para abordar a prática projetual no âmbito educacional do Design de Moda. Evocando os preceitos do pensamento sistêmico, agrega os conceitos da aprendizagem significativa e do pensamento visual. 
O quarto capítulo insere a descrição das condutas que orientaram a pesquisa e apresenta os métodos e técnicas utilizados. Com base nos liames teóricos e ações exploratórias, discorre sobre o trajeto que levou à construção do traçado metodológico.

No quinto capítulo foram sintetizadas as conexões geradas na vinculação das bases teóricas e da fase de diagnóstico, as quais possibilitaram a especificação das estratégias pedagógicas e instrumental projetual para intervenção em campo.

Exposta a plataforma de conexões estratégicas, são abordados, no sexto capítulo, a proposição do instrumental metodológico, suas aplicações em campo e os desdobramentos derivados do processo de investigação-ação. Finalmente, no sétimo capítulo, a explanação descreve os resultados projetuais e avaliativos, analisa o processo avaliativo por meio da triangulação de dados e apresenta a validação do instrumental, inferindo as considerações finais.

Antes de expor os fundamentos teóricos que guiaram este estudo, é fundamental que se conheça a dinâmica do ambiente acadêmico em que emergiram as percepções que o desencadearam, haja vista que os questionamentos incipientes da pesquisa surgiram na vivência do contexto e da prática docente. Neste sentido, descreve-se a seguir a síntese do projeto pedagógico do curso de Design de Moda da Universidade Estadual de Londrina (UEL) e o trajeto de questionamentos que levaram ao problema de pesquisa.

\subsection{O CONTEXTO}

O Projeto Pedagógico (PP) do Bacharelado em Design de Moda da Universidade Estadual de Londrina (UEL) foi implantado em 2005, a partir da reformulação do antigo curso de Estilismo em Moda, fundado em 1997, com o propósito de atender à solicitação da comunidade empresarial do grande polo confeccionista de vestuário de moda da região, considerado um dos maiores do país. Em vista da demanda das indústrias, que pleiteava a inserção de "criadores" de produtos, o primeiro curso direcionou seus esforços para a formação de profissionais capazes de planejar e desenvolver produtos de vestuário de moda. Este foco se mantém na proposta atual, porém a estrutura curricular foi completamente reconstruída. Sobre a plataforma do design, enfatiza o 
desenvolvimento do raciocínio projetual como o cerne do conjunto de habilidades e competências que foram definidas para o perfil do egresso.

Elaborada por uma equipe multidisciplinar - incluindo consultores da área de educação e empresários do setor-, que trabalhou por três anos, a reformulação do Projeto Pedagógico (PP) conectou as diretrizes do Ministério da Educação para os Cursos Superiores de Design e as exigências do cenário industrial da moda. Nesta direção, definiu-se que o curso deveria preparar o estudante para a autogestão e para "o aprender a aprender", por meio do ensino interativo. Assim, o atual PP do curso visa a uma formação conduzida com flexibilidade, autonomia e abordagem sistêmica, sob a qual seja estimulada a capacidade de pensamento reflexivo, analítico, sintético e crítico. Para tanto, a organização curricular foi estruturada em cinco eixos de conhecimento, que perpassam as quatro séries do curso: a) Fundamentação; b) Representação e Expressão; c) Gestão do Projeto; d) Sistemas de Produção; e) Configuração do Produto. A função de cada eixo na estrutura formativa pode ser visualizada no Quadro 1.

Quadro 1 - Contribuições dos Eixos de Conhecimento no Curso de Design de Moda da UEL.

\begin{tabular}{|c|c|}
\hline EIXO & CONTRIBUIÇÕES NA FORMAÇÃO \\
\hline FUNDAMENTAÇÃO & $\begin{array}{l}\text { Visão histórica e prospectiva, promovendo a compreensão das } \\
\text { relações usuário- sistema/produto de moda - ambiente. } \\
\text { Desenvolvimento da capacidade de organização e planejamento } \\
\text { na construção do conhecimento. }\end{array}$ \\
\hline EXPRESSÃO E REPRESENTAÇÃO & $\begin{array}{l}\text { Desenvolvimento da capacidade de expressão, para a elaboração } \\
\text { de conceitos e soluções em projetos de moda. }\end{array}$ \\
\hline GESTÃO DO PROJETO & $\begin{array}{l}\text { Gerenciamento do processo criativo, promovendo a efetiva } \\
\text { atividade projetual e a visão sistêmica. }\end{array}$ \\
\hline CONFIGURAÇÃO DO PRODUTO & $\begin{array}{l}\text { Transposição das especificações de projeto para a materialização } \\
\text { de soluções eficazes e inovadoras. }\end{array}$ \\
\hline SISTEMAS DE PRODUÇÃO & $\begin{array}{l}\text { Interação do pensamento projetual com a realidade produtiva, } \\
\text { promovendo a viabilização do projeto. }\end{array}$ \\
\hline
\end{tabular}

Fonte: Sanches e Hatadani (2014)

Cada eixo reúne um conjunto de unidades curriculares (disciplinas), as quais aportam conhecimentos para a construção das competências e habilidades 
imprescindíveis para um Designer de Moda. Nesta estrutura, as atividades pedagógicas de cada série se articulam de forma transversal, em busca de uma formação integrada que propicie o desenvolvimento do raciocínio projetual coeso e autônomo. Com esse intuito, o eixo central de Gestão do Projeto, que, ao contrário dos quatro restantes, inclui apenas uma disciplina por série, tem a função de promover a interação sistêmica entre as disciplinas da série a que corresponde, por meio de Projetos Integradores e Experimentais, até culminar no Trabalho de Conclusão de Curso (TCC) na quarta série.

Concomitantemente, a grande carga horária de Estágio obrigatório do curso, bem como as possibilidades diversificadas para atividades complementares e as parcerias com empresas locais, como campo de estudo para os projetos integradores e experimentais, proporcionam uma boa conexão dos estudantes com o mundo do trabalho, possibilitando a inserção da realidade produtiva/mercadológica nas atividades pedagógicas e, ainda, a relação destas com a atividade projetual.

Assim, o ambiente controlado da academia é permeado pelo fluxo de variantes do contexto externo, instituindo uma interface que vai crescendo no transcorrer do curso até mesclar-se completamente no último ano, quando ocorre o estágio de imersão e os alunos se dedicam, totalmente, ao trabalho em empresas do setor do vestuário. Tais experiências auxiliam a definição do foco dos Trabalhos de Conclusão de Curso (TCC) que, muitas vezes, são extraídos das vivências no campo de estágio. Para melhor apreensão desta organização, Sanches (2010) constrói um diagrama (Figura 1) que ilustra o percurso formativo, enfatizando a gestão do projeto como eixo central e a inserção de parcerias com os âmbitos produtivo e mercadológico. Desta perspectiva, vislumbra-se que os conhecimentos tecno-expressivos, a capacidade criativa e as variáveis do contexto sejam equacionados com maior eficácia na atuação profissional, quando o egresso se integre ao mercado de trabalho. 
Figura 1 - Estrutura Básica do Curso de Design de Moda da UEL

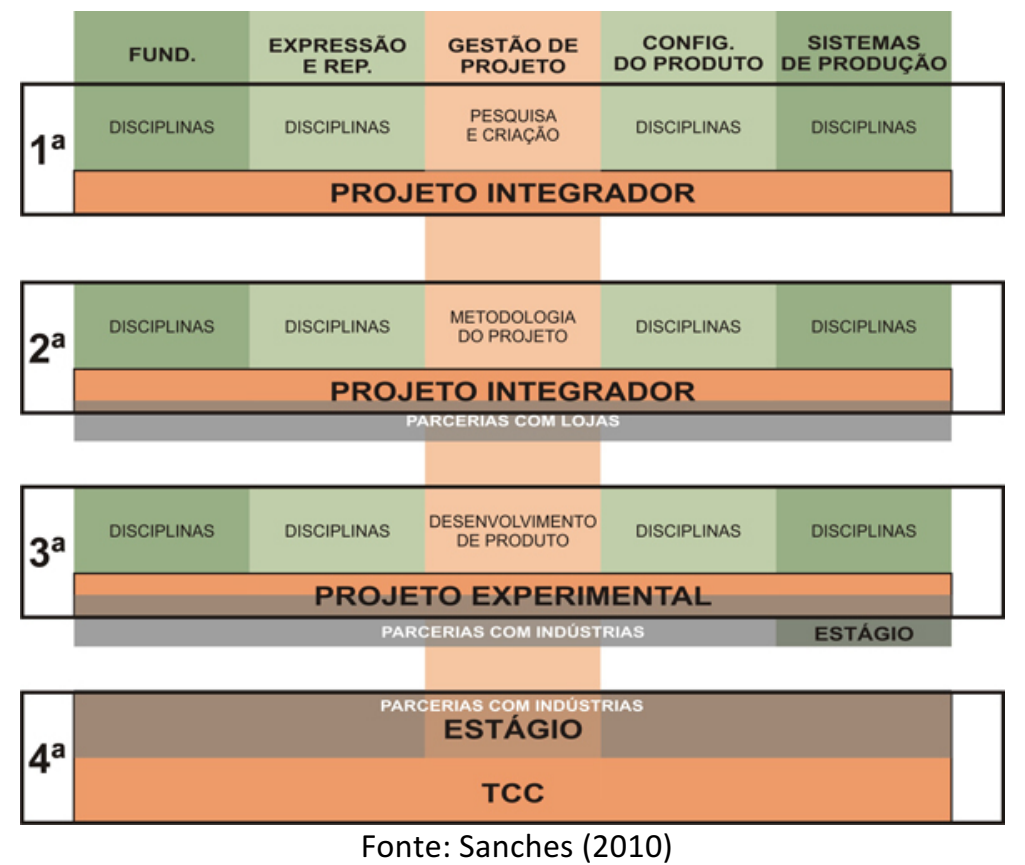

Considerando os objetivos de conteúdos trabalhados em cada série, bem como as habilidades e competências que provêm destes, formulam-se diretrizes básicas para cada atividade interdisciplinar, as quais devem contemplar estes propósitos no decorrer do processo projetual. Além disso, propõe-se que a postura didática deve estimular o estudante a pesquisar e levantar oportunidades, ampliando a capacidade de identificar demandas tangíveis e intangíveis na contextualização do universo projetual.

Para maior entendimento das práticas interdisciplinares no curso, relata-se a estrutura didática de algumas estratégias pedagógicas de interação, começando pelos Projetos Integradores e Experimentais, os quais vinculam todas as unidades curriculares de cada série em prol de um mesmo objetivo. O percurso desses projetos inclui desde a identificação de demandas até a prototipagem e defesa das propostas finais. Assim, para efeito de organização, esta atividade é construída em quatro grandes fases, que auxiliam a administração do cronograma e a organização da interação das disciplinas inseridas em cada fase do projeto. É essencial enfatizar, de acordo com Sanches (2010), que estas etapas não ocorrem de forma linear e isolada, mas sim de modo cíclico, no qual é comum retomar as fases já transpostas ou administrá-las, simultaneamente, até mesmo porque estas não presumem uma sequência de procedimentos técnicos prédeterminados, apenas indicam os focos de ação em relação ao processo geral e auxiliam 
os estudantes e professores no gerenciamento do tempo, em conformidade com o calendário institucional (Figura 2).

Figura 2 - Fases dos Projetos Integradores e Experimentais

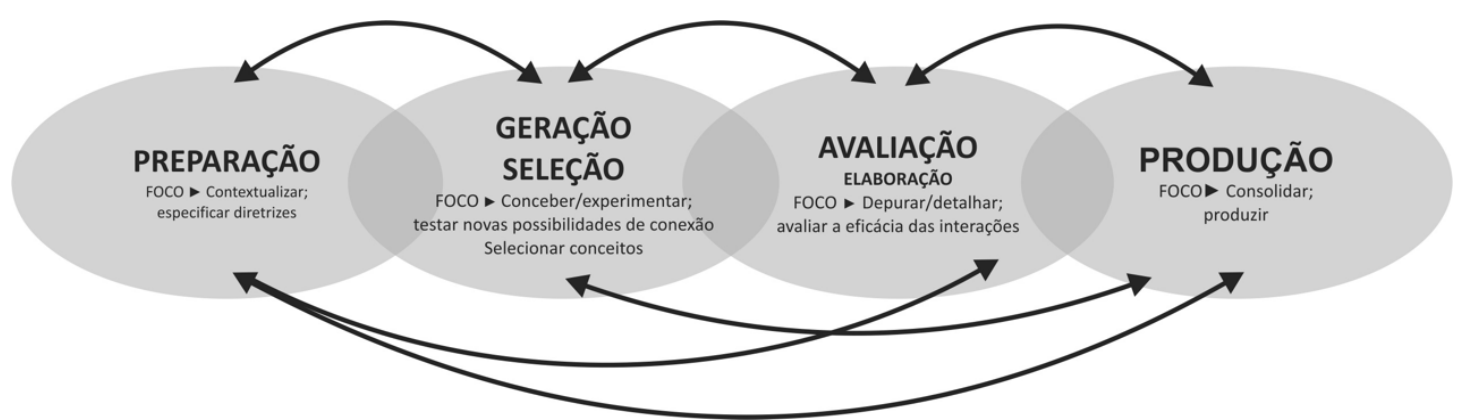

Fonte: Sanches e Hatadani (2014 adaptado de SANCHES, 2010)

Sabe-se que é preciso ter cautela para que modelos ilustrativos não sejam interpretados como um roteiro de procedimentos preestabelecidos, por isso, ressaltase que a Figura 2 visa apenas esclarecer o leitor, já que o processo de design não poderia ser definido por um esquema horizontalizado, como descreve Sanches (2010). Considerando tal ressalva, destaca-se, a seguir, o fluxo das principais informações e procedimentos envolvidos nas atividades projetuais do curso.

A) Preparação: compreender o contexto em que se insere o projeto é fundamental, por isso as ações de investigação são auxiliadas pelas unidades curriculares, que estudam fatores sociais, mercadológicos e tecnológicos, sempre em interação com a disciplina de gestão de projeto em cada série.

B) Geração e avaliação: a etapa de geração e avaliação de possibilidades de solução envolve, principalmente, as disciplinas do eixo de configuração de produto, sobrepostas às disciplinas do eixo de Sistemas de Produção, já que o ciclo geração _ avaliação _ seleção envolve experimentações concretas e se repete mais de uma vez, associando os conhecimentos tecno-produtivos aos expressivos.

C) Produção: se concentram as ações em direção à consolidação efetiva do projeto, quando os conhecimentos de sistemas produtivos são canalizados à confecção de protótipos de teste e peça piloto, bem como as habilidades de representação e expressão para a documentação final do projeto. 
Nesta direção, os Projetos Integrador e Experimental envolvem situações projetuais que variam a cada ano, provenientes dos objetivos pedagógicos, das escolhas dos estudantes e das parcerias externas. Contudo, o nível de complexidade é ampliado a cada série e parte da análise da plataforma de conhecimentos que os eixos devem compartilhar em uma mesma série. Assim, na primeira série, o foco é a linguagem e a exploração das ferramentas da criatividade, utilizando como contexto o universo pessoal. A segunda série introduz a conexão com o mercado, a partir do estudo de público-alvo e conceito de marca para, enfim, na terceira série, interagir profundamente com o contexto social e mercadológico, já que nesta fase o projeto é realizado em parceria com uma indústria, transportando o estudante para um cenário de muitas limitações e variáveis, no qual o raciocínio projetual se amplia para a concepção de sistemas de produtos e serviços.

Ressalta-se que as disciplinas do eixo de Gestão do Projeto são responsáveis pelo acompanhamento das interações, auxiliando o aluno em cada etapa e garantindo que o planejamento seja cumprido - ou adaptado - durante o trajeto até o resultado final. Essa posição não estabelece uma relação hierárquica (nem das disciplinas, tampouco entre os professores), visando apenas à mediação do planejamento coletivo por série e coerência da condução do processo projetual.

Sob este direcionamento, estas disciplinas transformam-se em um "espaço de reflexão em torno do fazer" (COELHO, 2006, p. 40), em que os estudantes são estimulados a decidirem sobre as ferramentas metodológicas que usarão em cada fase do projeto, dependendo do foco de ação da fase em questão e do conhecimento prévio já exercitado. Todavia, existem momentos de assessoramento com os professores para análise da coerência das escolhas individuais. Destaca-se que os procedimentos peculiares a cada etapa são orientados pelo professor da área específica. Para tanto, a documentação contínua do trajeto é essencial, por conseguinte, cada aluno produz uma série de registros que facilitam a sistematização da conduta projetual, assim como a comunicação e a interação entre os eixos de conhecimento do curso.

Uma das principais formas de registro para comunicação é a Ficha-síntese, um documento criado neste curso para resumir as delimitações do projeto, de forma organizada, e facilitar a interação entre as disciplinas envolvidas no processo. 
Cabe destacar que, embora o intercâmbio das unidades curriculares esteja assegurado pelos Projetos Integradores e Experimentais, a estrutura curricular interativa e o amadurecimento de posturas didáticas mais colaborativas estimularam os docentes a adotarem condutas flexíveis e a atuarem de modo mais interligado, o que impulsiona, cada vez mais, a realização de atividades interdisciplinares.

No decorrer de uma década, as constatações identificadas nas práticas em sala de aula e nas discussões das reuniões pedagógicas, realizadas para feedback e planejamento das atividades do curso, em geral e de cada série, ocasionaram a evolução das ações integradoras. Com base nestas verificações, foram necessários ajustes como, por exemplo, a redução do número dos Projetos Integradores e Experimentais em cada série, para dar espaço a práticas interdisciplinares menores e mais curtas (práticas preparatórias), as quais possibilitaram a interação de ações didáticas específicas que preparam o estudante para uma gestão mais autônoma de tais projetos e do Trabalho de Conclusão de Curso (TCC). As atividades preparatórias são continuamente introduzidas no primeiro semestre, antes dos projetos maiores que ocorrem no segundo semestre, sendo coordenadas pelo docente da disciplina do eixo de Gestão do Projeto ou por qualquer outro docente, independentemente do eixo ao qual pertença.

O enfoque dos projetos principais também evoluiu, somando-se à delimitação original uma demarcação por segmentos de usuários, de acordo com os perfis corpóreos, estudados nas disciplinas que tratam de modelagem e usabilidade, e comportamentos de consumo explorados em cada série, conforme apresentado no Quadro 2.

Quadro 2 - Delimitação atual das atividades integradoras

\begin{tabular}{|c|c|c|c|c|}
\hline SÉRIE & $1^{\underline{a}}$ & $2^{\underline{a}}$ & $3^{a}$ & $4^{a}$ \\
\hline $\begin{array}{l}\text { DISCIPLINA DO } \\
\text { EIXO GESTÃO } \\
\text { DO PROJETO }\end{array}$ & $\begin{array}{l}\text { PESQUISA E } \\
\text { CRIAÇÃOO }\end{array}$ & $\begin{array}{l}\text { METODOLOGIA DO } \\
\text { PROJETO }\end{array}$ & $\begin{array}{l}\text { DESENVOLVIMENTO } \\
\text { DE PRODUTO }\end{array}$ & $\begin{array}{l}\text { TRABALHO DE } \\
\text { CONCLUSÃO DE } \\
\text { CURSO }\end{array}$ \\
\hline $\begin{array}{l}\text { OBJETIVOS DA } \\
\text { DISCIPLINA }\end{array}$ & $\begin{array}{l}\text { Desenvolver a } \\
\text { percepção do novo, } \\
\text { viabilizando a } \\
\text { aquisição das } \\
\text { habilidades criativas, } \\
\text { através de técnicas e } \\
\text { exercícios que } \\
\text { estimulem a } \\
\text { expressão. }\end{array}$ & $\begin{array}{l}\text { Conhecer e exercitar } \\
\text { as etapas do projeto } \\
\text { de design, por meio } \\
\text { de ferramentas de } \\
\text { gestão projetual, } \\
\text { promovendo a visão } \\
\text { sistêmica. }\end{array}$ & $\begin{array}{l}\text { Aplicar o } \\
\text { pensamento } \\
\text { projetual com } \\
\text { direcionamento } \\
\text { mercadológico/indus } \\
\text { trial e conceitos de } \\
\text { sustentabilidade, no } \\
\text { desenvolvimento de } \\
\text { sistemas (artefatos, } \\
\text { processos e serviços } \\
\text { de moda) }\end{array}$ & $\begin{array}{l}\text { Canalizar as } \\
\text { vivências } \\
\text { acadêmicas de modo } \\
\text { autônomo e } \\
\text { abrangente para a } \\
\text { integração ao } \\
\text { mercado de } \\
\text { trabalho, } \\
\text { equacionando visão } \\
\text { sistêmica, prática } \\
\text { fundamentada e } \\
\text { capacidade de }\end{array}$ \\
\hline
\end{tabular}




\begin{tabular}{|c|c|c|c|c|}
\hline & & & & $\begin{array}{l}\text { síntese para a gestão } \\
\text { da pesquisa na } \\
\text { concepção de } \\
\text { produtos (e/ou } \\
\text { processos/serviços) } \\
\text { inovadores e } \\
\text { factíveis. }\end{array}$ \\
\hline $\begin{array}{l}\text { SEGMENTO } \\
\text { ABORDADO }\end{array}$ & $\begin{array}{l}\text { UNIVERSO PESSOAL } \\
\text { DO ESTUDANTE } \\
\text { (FEMININO) }\end{array}$ & $\begin{array}{l}\text { INFANTIL } \\
\text { (MASCULINO E } \\
\text { FEMININO) }\end{array}$ & MASCULINO & LIVRE \\
\hline $\begin{array}{l}\text { COMPETÊNCIAS } \\
\text { ALMEJADAS }\end{array}$ & $\begin{array}{l}\text { Construção de } \\
\text { repertório básico, } \\
\text { associando os } \\
\text { conhecimentos e } \\
\text { conteúdos } \\
\text { abordados sobre as } \\
\text { técnicas de } \\
\text { criatividade à prática } \\
\text { projetual. }\end{array}$ & $\begin{array}{l}\text { Construção de } \\
\text { repertório } \\
\text { intermediário, } \\
\text { associando, à prática } \\
\text { projetual, os } \\
\text { conhecimentos } \\
\text { adquiridos na } \\
\text { primeira série com } \\
\text { conteúdos sobre } \\
\text { público-alvo e } \\
\text { conceito de marca. }\end{array}$ & $\begin{array}{l}\text { Ampliação do } \\
\text { repertório anterior, } \\
\text { interatuando com } \\
\text { cenários produtivos } \\
\text { e mercadológicos, } \\
\text { para promover a } \\
\text { associação dos } \\
\text { conhecimentos de } \\
\text { gestão e } \\
\text { sustentabilidade à } \\
\text { prática projetual. }\end{array}$ & $\begin{array}{l}\text { Capacidade de } \\
\text { realizar um projeto } \\
\text { de alta } \\
\text { complexidade, } \\
\text { gerindo, de modo } \\
\text { autônomo, a } \\
\text { interação entre a } \\
\text { investigação } \\
\text { científica, a prática } \\
\text { projetual e a } \\
\text { produção material. }\end{array}$ \\
\hline
\end{tabular}

Fonte: elaborado pela autora adaptado de Sanches e Hatadani (2014)

Os projetos vivenciados ao longo dos anos indicaram que o cumprimento desta integração transversal só ocorreria de maneira satisfatória se houvesse a flexibilização de certas práticas pedagógicas institucionalizadas, a exemplo do horário de aulas. Isto porque, ao contrário dos currículos estruturados em grade fixa (nos quais cada disciplina tem hora e local permanente em todas as semanas do semestre letivo), a integração conduz a ações inovadoras de ensino, exigindo a reorganização continuada do tempo e das atividades programadas, além da verificação constante do desempenho e das dificuldades dos estudantes. Desta forma, é habitual que os professores alterem o planejamento e o percurso do projeto, no intuito de redesenhar o caminho da aprendizagem e da interação. Tal apontamento é corroborado por Fazenda (2008a, p.8), ao afirmar que "nas questões da interdisciplinaridade, é possível planejar e imaginar, porém é impossível prever o que será produzido e em que quantidade ou intensidade".

Por este motivo, a partir de 2014 o horário de aulas do curso de Design de Moda da Universidade Estadual de Londrina (UEL) deixou de ser definido por semestres e passou a ser determinado semanalmente, de acordo com as necessidades identificadas em sala. Desde então, muitas aulas têm sido ministradas por mais de um professor ao mesmo tempo, o que intensifica a prática integradora e favorece a interdisciplinaridade, pois, como afirma Fazenda (2002, p. 51): “A interdisciplinaridade caracteriza-se pela 
intensidade das trocas entre os especialistas e pelo grau de integração real das disciplinas no interior de um mesmo projeto de pesquisa".

Como se pode averiguar, a viabilização de práticas interdisciplinares envolve um planejamento eficiente, um acompanhamento constante e muita disponibilidade para novas adequações do percurso. No caso do curso em questão, o projeto pedagógico já foi concebido com esta intenção integradora, mas ainda existem muitas arestas a aparar, principalmente, em relação ao processo avaliativo integrado. Contudo, as supervisões de estágio confirmam que os alunos deste curso, ao adentrarem o contexto de uma indústria, demonstram uma visão ampliada em relação à gestão do design, atuando de forma ágil e participativa nos diversos processos que acontecem na indústria de moda.

Pelo exposto, é possível afirmar que o curso de Design de Moda da UEL vem, sistematicamente, procurando aprimorar a proposta do Projeto Pedagógico (PP), ainda que enfrente inúmeros desafios. No entanto, é essencial ressaltar que, apesar das dificuldades, o curso tem conseguido direcionar as ações pedagógicas para a interação entre teoria e prática e a transversalidade de saberes, condições essenciais para o ensino do design. Da mesma forma, a atmosfera de interação continuada, que compõe este ambiente acadêmico, oferece um campo favorável às investigações acerca do processo projetual.

Assim, a presente pesquisa foi envolvida por um contexto em que se pretende a construção transversal do raciocínio projetual, na qual as unidades curriculares de cada eixo de conhecimento compartilham a responsabilidade sobre este objetivo. Neste ambiente, ainda que a competência expressiva e a habilidade em articular a sintaxe visual no processo projetual sejam construídas na mesma transversalidade, no decorrer da formação, o curso conta com unidades curriculares que tratam, especificamente, dos seus fundamentos: Metodologia Visual, Composição e Laboratório de Expressão. Essas unidades estão alocadas no eixo de Configuração do Produto e, muitas vezes, os docentes responsáveis costumam entrar em sala em conjunto com os professores do eixo de Gestão do Projeto, visando à criação de um ambiente favorável aos ciclos de geração, síntese e análise de possibilidades formais.

Levando em conta a importância do contexto em situações de ensino e de aprendizagem, as características aqui expostas foram fundamentais para o 
direcionamento metodológico da pesquisa, já que o ambiente estudado contava com rotinas interativas e condutas flexíveis, as quais apontavam um posicionamento colaborativo na construção do conhecimento. Da mesma forma, a grande proximidade da pesquisadora com a evolução desta realidade propiciou a visão panorâmica do percurso acadêmico, o que favoreceu uma apreciação do raciocínio projetual em formação contínua. Consequentemente, as inferências não se resumiram ao escopo de uma única unidade curricular ou à formação de uma habilidade isolada. Para compreender essa trajetória, os próximos tópicos deste capítulo descrevem o conjunto de fatores que conduziram as decisões sobre o traçado metodológico do estudo.

\subsection{DO CONTEXTO À PERGUNTA}

Com o propósito de esclarecer as origens desta pesquisa, são expostas a seguir as confluências entre as demandas do contexto e a trajetória pessoal. Considerando que o primeiro passo em uma direção investigativa, geralmente, é ocasionado por motivações individuais, assumem-se tais ensejos como justificativa para mesclar, no próximo tópico, a redação em primeira pessoa.

\subsubsection{ENVOLVIMENTO DA PESQUISADORA}

No ambiente descrito anteriormente, participei diretamente da autoria do novo projeto pedagógico do curso, desenvolvi a prática docente e edifiquei um percurso de pesquisa na área de metodologias de projeto. Do decorrer desta trajetória, a reflexão sobre o âmbito do ensino/aprendizagem imbricou-se, permanentemente, à minha pesquisa, pois me interessava, especialmente, o instrumental metodológico para facilitar a prática projetual entre os discentes.

Neste sentido, a investigação para o mestrado se destinou à organização de diretrizes metodológicas para o desenvolvimento de produtos de vestuário de moda no âmbito acadêmico, estudando tal processo sob a ótica do design. Para isso, a pesquisa envolveu relacionar as ações práticas do desenvolvimento de produtos ao projeto de design, identificando as etapas-chave deste processo e as variáveis relevantes para a síntese de uma solução. Na época, já se acreditava em uma abordagem metodológica 
flexível, na qual o estudante pudesse ter autonomia para lidar com as ações projetuais ou, ainda, para decidir sobre as estratégias metodológicas que usaria. Todavia, a proposta não se estendeu ao aprofundamento em técnicas ou métodos específicos. A intenção era, em primeira instância, a identificação de diretrizes para organizar um trajeto projetual, já que o Design de Moda era curso muito recente na academia e a maioria dos referenciais teóricos do Design não tratava particularmente desta área. 0 estudo das ferramentas específicas, no entanto, continuou sendo um foco de inquietação nos últimos anos.

É habitual, quando se atua no âmbito educacional da metodologia do design, acreditar que professores de projeto têm a função de auxiliar os estudantes, por meio de métodos e técnicas, a conduzirem seus raciocínios às boas soluções projetuais. Nessa linha de raciocínio, um tanto reducionista, ao se quebrar a casca simplista para desvendar as camadas subjacentes, pode-se refletir que da coerência dessa condução dependem não só o sucesso dos resultados, mas principalmente a eficácia das decisões que levarão a tais resultados. E, ainda, que a construção de parâmetros para essa coerência está vinculada ao ambiente pedagógico e às interações que estudantes e professores compartilham durante o percurso formativo. Por isso, as inquietações que originaram as indagações deste estudo nasceram no âmbito da prática docente, sob as influências do contexto vivenciado e, certamente, moldadas por essa visão processual do ensino/aprendizagem de projeto.

A longa experiência docente nas áreas da composição visual e das metodologias do design, no curso de Design de Moda da Universidade Estadual de Londrina (UEL), aguçou algumas inquietações que derivavam da integração destas duas áreas. Estas observações indicavam carências recorrentes no processo de transposição da delimitação projetual ${ }^{1}$ para a geração da composição estético-formal dos artefatos projetados. Isso estimulou um olhar minucioso sobre o instrumental metodológico destinado a facilitar a sintaxe visual e, por conseguinte, a expressão semântica em projetos de Design de Moda. Nesta direção, as investigações incipientes que

\footnotetext{
${ }^{1}$ A expressão delimitação projetual foi adotada para designar a fase projetual destinada à investigação de contexto, identificação do problema, definição de objetivos e conceito. Essa fase recebe diversas denominações entre os estudiosos do proceso de design (especificação projetual, pré-concepção, problematização, programa, etc.), contudo foi decidido manter a nomenclatura usada no ambiente educacional estudado.
} 
culminaram na presente pesquisa demonstraram um campo vasto e fértil para a exploração de conteúdos semânticos na configuração estético-formal do vestuário de moda. No entanto, a mesma vivência também constatou a dificuldade em adequar o instrumental metodológico, no que concerne à síntese e à transposição de atributos formais/visuais aos artefatos projetados, como será explicado no próximo tópico.

Logo, uma indagação surgiu: as estratégias para direcionar o planejamento da dimensão sintático-semântica dos artefatos projetados precisam ser aprimoradas?

Contudo, para confirmar se a problemática sentida era realmente significativa e passível de racionalização, foi necessário assumir uma postura crítica que elucidou pontos primordiais: a) a carência não era pessoal (de um aluno ou minha como professora), visto que foi registrada sistematicamente através de anos de observação em vários grupos de alunos e, também, era citada repetidamente por outros professores de projeto nas reuniões de planejamento em colegiado; b) a dificuldade acerca das estratégias metodológicas se referia à conexão entre a delimitação projetual e a sintaxe formal/visual do artefato, indicando uma abordagem processual que sugeria um aporte relevante para o ensino/aprendizagem de projeto; c) a receptividade e o retorno espontâneo dos alunos, acerca de algumas estratégias diferenciadas inseridas, em sala de aula, sinalizaram um caminho de abordagem que parecia merecer maior exploração; d) a experiência em outras escolas, em aulas de especialização lato sensu, mostrou que alunos graduados em contextos acadêmicos distintos partilhavam das mesmas inquietações.

Cabe enfatizar, dado o papel exercido pelo vestuário de moda no âmbito da expressão individual e das representações sociais, que a preocupação com a função estético-simbólica do artefato projetado é uma premissa básica para quem se dispõe a lecionar projeto de design no campo da moda. O processo de ensino/aprendizagem, neste universo, costuma canalizar muitas ações didáticas em prol da edificação da competência expressiva dos estudantes, com o objetivo de prepará-los para articular códigos comunicativos na configuração destas interfaces vestíveis. Nesta linha de raciocínio, uma proposta de investigação destinada a facilitar esta articulação no trajeto projetual já se apresentava, implicitamente, em um indício de contribuição. Em contrapartida, a formação e experiência profissional, que integram o design gráfico e o 
design de moda, poderiam trazer uma abordagem transversal a partir do olhar multifocal.

A trajetória descrita convergiu em questões incipientes que forneceram subsídios para o início do doutoramento em 2012 na Universidade de São Paulo. Como o propósito era estudar o instrumental metodológico no ensino/aprendizagem de projeto, diretamente no universo acadêmico do Design de Moda, a investigação de doutoramento tomou a forma de projeto de pesquisa, denominado Incubadora de Novas Ideias: laboratório de estudo de metodologias para a sintaxe visual, alocado no departamento de Design da Universidade Estadual de Londrina e coordenado por mim.

\subsubsection{DA VIVÊNCIA AO OBJETO DE ESTUDO}

Embora o foco do estudo tenha sido formalmente reconhecido por exigência da pesquisa de doutoramento, convém ressaltar que a investigação sorveu observações amadurecidas no decorrer de dezesseis anos de docência.

Também é importante compreender que tais percepções foram construídas a partir de três posições distintas de observação: como professora diretamente responsável pela gestão metodológica de projetos, na disciplina Metodologia do Projeto (2a série do curso de graduação- Eixo de Gestão do Projeto); como professora colaboradora na prática projetual, mas não responsável pela gestão metodológica de projetos, na disciplina Metodologia Visual (1a série do curso de graduação - Eixo de Configuração do Produto); como professora responsável pela construção de base teórico-prática para compreensão da comunicação imagética, independente de práticas projetuais, na disciplina Comunicação Visual na Moda - Especialização lato sensu em moda: produto e comunicação. Desta forma, foi possível alternar os pontos de vista e construir um olhar multifocal que permitiu a sobreposição e, posteriormente, a interação de percepções a respeito da gestão do trajeto projetual, do papel da linguagem não verbal no projeto de Design de Moda e, ainda, das possibilidades de aplicação de ferramentas de síntese visual.

As observações embrionárias identificaram pontos críticos que se relacionavam, principalmente, à fase inicial da geração de ideias, desencadeando o fluxo de 
questionamentos incipientes que levaram ao foco investigativo, conforme exposto a seguir:

A) Parecia haver entraves para impulsionar a experimentação formal em tridimensionalidade. *Por que isso ocorre? Faltam ferramentas para auxiliar a geração da forma?

B) Apesar de existir uma delimitação que incluía objetivos ergonômicos e produtivos, nas primeiras tentativas de configuração, muitas vezes, havia uma inclinação à reprodução de tendências de moda, mostrando um descolamento dos quesitos tecnológicos e questionamentos ergonômicos preestabelecidos. * Não se mantém um olhar panorâmico sobre as relações existentes entre as variáveis? *Existem falhas na delimitação projetual? * Os alunos refletem sobre as conexões existentes entre as variáveis que elencam nas suas delimitações projetuais?

C) Logo, iniciar a geração de alternativas de configuração ou assumir critérios para selecioná-las era motivo de angústia. Perguntas como: "Professora, por onde eu começo?", ou comentários dos docentes sobre o "travamento para impulsionar a geração de ideias em tridimensionalidade" ilustravam, frequentemente, essa situação. *O que poderia impulsionar a sintaxe da forma com mais naturalidade?

D) Vários alunos expressavam dificuldade em aproveitar as ferramentas de síntese imagética. Comentários como: "Não sei bem como tirar as formas da imagem para o tridimensional" ou "Tenho que usar exatamente as cores que estão aqui? Acho que a imagem está me engessando" ilustraram, repetidamente, o problema. *As ferramentas de síntese expressiva adotadas - painéis de síntese imagética - não estão cumprindo o seu papel? *É possível otimizar o uso dessas ferramentas para auxiliar a composição tridimensional?

E) A experiência em especializações lato sensu, dentro e fora da UEL, em disciplinas de planejamento de produto e composição visual, mostrou dois pontos importantes: por um lado, os alunos formados em moda por outras escolas também comentavam sobre as deficiências em explorar os painéis imagéticos, embora acreditassem no poder da imagem como canal expressivo; por outro 
lado, alguns exercícios de construção de imagem, que envolviam a análise de enunciados simbólicos a partir da estimulação sensorial, apresentaram ótimos resultados de síntese expressiva, até mesmo para os alunos que vinham de graduações nas quais não desenvolveram habilidades de representação gráfica.

*Pode-se ampliar o aproveitamento das ferramentas de síntese imagética?

Para esclarecer em que consiste a afirmação sobre a geração em tridimensionalidade, é essencial assinalar que, no contexto estudado, a modelagem tridimensional é uma importante ferramenta de estimulação criativa e se agrega ao projeto nas primeiras etapas, contribuindo para a síntese de diretrizes de experimentação do espaço em integração ao corpo.

Também é fundamental destacar que as dificuldades citadas não se referiam à capacidade de gerar composições imagéticas e, muito menos, desqualificavam tais ferramentas. Pelo contrário, justamente por acreditar no valor da síntese por meio do pensamento visual, questionava-se como otimizá-lo. Os questionamentos enfocavam o processo de transposição da imagem para configuração e não a habilidade isolada de construir sínteses imagéticas, algo que os alunos do curso estudado já faziam muito bem. Para reforçar, como já comentado, algumas estratégias diferenciadas, inseridas em sala de aula, sinalizaram novas possibilidades de aplicação do pensamento visual.

Com base nas referidas reflexões, dois processos se destacaram como pontos cruciais: a delimitação projetual e a transposição de códigos $^{2}$ visuais expressivos para a experimentação formal. Porém, é essencial resgatar que, apesar de tais processos aludirem à prática projetual do design, era imprescindível tomá-los como objetos de estudo inseridos em ambiente educacional e assumir que os questionamentos elencados pertenciam, simultaneamente, ao campo das metodologias do design e ao âmbito do ensino/aprendizagem.

Por conseguinte, como em qualquer ambiente educacional, as relações humanas e estruturais do contexto poderiam ter influência sobre tais questões. Nesta direção, é pertinente pensar que as dificuldades poderiam sofrer a influência da interação entre

${ }^{2}$ O termo código é interpretado como conjunto de sinais (signos) que se articulam sob alguma organização para expressar uma informação (verbal e não verbal). 
aluno e professor, ou derivarem do direcionamento escolhido para a construção do Projeto Pedagógico (PP). No entanto, alguns fatores contribuíram para a decisão de centrar esforços apenas no ensino/aprendizagem de metodologia projetual: a) o interesse pessoal era contribuir no aprimoramento do instrumental para o ensino de projeto e não estudar um possível fenômeno organizacional que, certamente, seria mais bem conduzido por um psicólogo ou um pedagogo; b) a demanda também acometia espaços e grupos de sujeitos externos ao contexto da Universidade Estadual de Londrina (UEL); c) o olhar da investigadora, em posição tríplice, evidenciou uma contribuição em potencial para o campo das metodologias do design; d) a ótima repercussão institucional do Projeto Pedagógico do curso e os resultados positivos da avaliação anual aferida pelos discentes sugeriam uma estrutura pedagógica aparentemente saudável.

Assim, a problemática de estudo foi concentrada na Disciplina de Metodologia de Projeto, uma vez que esta está diretamente vinculada à gestão do processo das práticas projetuais (eixo de Gestão do Projeto) e representa o momento, no percurso formativo, em que os estudantes diversificam as estratégias para conduzirem o projeto (práticas projetuais preparatórias).

Com base nas constatações anteriores, foi possível vislumbrar o direcionamento da pesquisa de doutoramento, a qual se debruçou sobre o ensino de projeto no curso de Design de Moda, focando como objeto de estudo o instrumental metodológico para a sintaxe formal/visual no projeto de vestuário de moda. A esta altura, ponderando objeto, questionamentos incipientes e perfil da pesquisadora, percebeu-se um caminho qualitativo e propositivo para a abordagem da pesquisa.

\subsubsection{DO OBJETO À PERGUNTA}

O delineamento do objeto demonstrou que a questão da pesquisa se formaria na transversalidade de três campos de conhecimento, da pedagogia, do design e da comunicação (Figura 3). A partir de cada campo geral, afunilou-se, respectivamente, para o ensino/aprendizagem de projeto, a metodologia projetual do design e a comunicação não verbal visual. 
Figura 3 - Transversalidade da questão de pesquisa

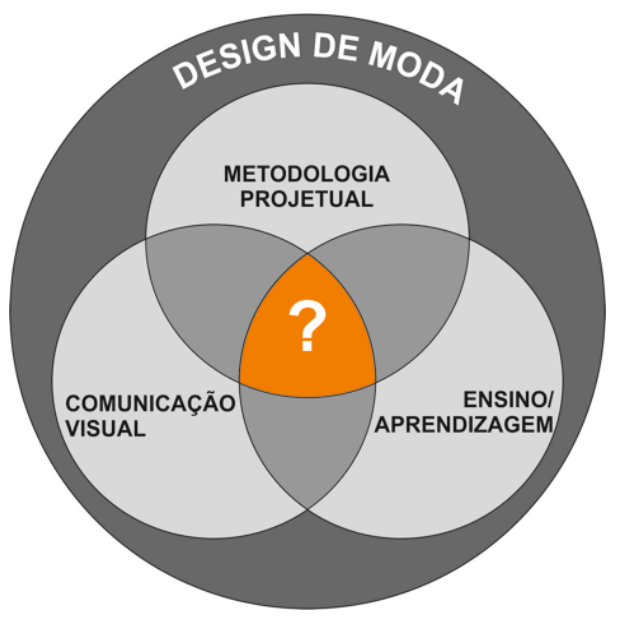

Fonte: elaborado pela autora (2012)

Sobre esta estrutura, foi demarcada uma indagação preliminar: como aprimorar, no âmbito educacional do Design de Moda, as estratégias metodológicas para o direcionamento sintático-semântico na geração da forma do vestuário de moda?

A edificação das bases teóricas partiu da pergunta preliminar, que direcionou a revisão de literatura, estabelecendo um quadro teórico do qual se extraíram os pontos para a definição da questão problema definitiva. Ao agregar as bases teóricas aos questionamentos incipientes sobre a delimitação projetual e a transposição de códigos visuais para a sintaxe formal, tornou-se claro que a pesquisa se moveria em direção a uma proposta de estratégias metodológicas para facilitar a sintaxe da forma, apoiandose nos parâmetros das pedagogias construtivistas, da gestão sistêmica do design e do pensamento visual.

Concordando com Flick (2004), admitiu-se que as questões de uma pesquisa qualitativa são aperfeiçoadas ao longo do caminho do projeto e a questão preliminar, após a investigação bibliográfica, foi polida e reformulada da seguinte forma:

Pergunta problema: Como integrar, no âmbito do ensino de projeto no design de moda, estratégias que associem a gestão sistêmica e o pensamento visual, para auxiliar o direcionamento e geração da sintaxe visual/formal dos artefatos projetados? 


\subsubsection{DA PERGUNTA À HIPÓTESE}

Submetendo a questão principal a um olhar retrospectivo sobre a fundamentação teórica, foram explicitados alguns pontos que levaram à definição de pressupostos para a ação em campo: a) a consciência da relação sintaxe-semântica é primordial para a efetividade das estratégias entre os alunos; b) a sintaxe da forma depende da gestão integrada dos objetivos projetuais; c) a gestão da informação é fundamental para a gestão integrada dos objetivos; d) a síntese por meio de estratégias gráfico-visuais, já utilizada para direcionamentos estéticos, poderia se estender à fase de delimitação projetual (gestão de informações).

Com a cautela ${ }^{3}$ recomendada pelos autores que instruem sobre pesquisa qualitativa, delimitou-se uma hipótese diretriz, vinculando-se as observações anteriores da prática docente e as contribuições teóricas. O propósito da formulação dessa diretriz, descrita a seguir, foi delinear indicadores relativos ao modo de tratar a situação investigada e aos modos de agir e observar em campo. Como o intuito primordial desta pesquisa é contribuir na transformação positiva do ambiente estudado, a hipótese priorizou, entre as várias consequências que se poderiam prever para a referida associação, aquela que poderia promover a melhoria da transição entre as fases de delimitação projetual, síntese visual e experimentações formais, como explicado no tópico das questões incipientes.

\section{Hipótese: A associação da gestão sistêmica das informações ao pensamento visual promove a convergência entre os objetivos projetuais e a síntese de códigos expressivos, facilitando a percepção de estruturas compositivas para a experimentação formal.}

\footnotetext{
${ }^{3}$ É evidente, na bibliografia que discute a pesquisa qualitativa, a prudência (ou até restrições) ao falar sobre a formulação de hipóteses, que comumente é relacionada com a abordagem positivista e rotulada como determinista. É evidente que, sob uma perspectiva experimental, na qual se isola um fenômeno e se controlam as variáveis para comprovar as relações de causalidade expressas na hipótese, é difícil perceber compatibilidade com as ciências sociais/humanas. Entretanto, autores como André (2005), Tripp (2005) e Thiollent (1996), tratando de pesquisa etnográfica em educação e investigação-ação, recomendam o uso de hipóteses de forma flexível. Assim, o pesquisador não segue hipóteses rígidas, fica atento às evidências em campo que conduzam a novas perspectivas de análise. "As hipóteses (ou diretrizes) qualitativas orientam, em particular, a busca de informação pertinente e as argumentações necessárias para aumentar (ou diminuir) o grau de certeza que podemos atribuir a elas." (THIOLLENT, 1996, p.34)
} 
$\mathrm{Na}$ intenção de proporcionar a percepção da linha de raciocínios que guiou o percurso investigativo até a verificação da hipótese, a seguir são apresentadas as bases teóricas que propiciaram a definição de estratégias pedagógicas e projetuais para a proposição de ferramentas inovadoras e a aplicação em campo. 


\section{CAPÍTULO 2}

Conexões teóricas sobre o vestuário de moda 


\section{VESTUÁRIO DE MODA: A INTERFACE VESTÍVEL}

Para estender a percepção sobre os conhecimentos que envolveriam o estudo do objeto, indicar interseções conceituais e clarificar os limites do problema de pesquisa, o repertório teórico acumulado pela experiência precisou de organização e exploração de novas conexões. Neste sentido, uma revisão de literatura exploratória edificou os fundamentos teóricos para a formulação da questão-problema definitiva.

Em relação à fundamentação, é importante prevenir que esta pesquisa nunca se fixou em discutir limites entre o campo da moda e do design, visto que o ponto de interesse é justamente a convergência entre eles. Assim, foi tomado que se a essência do design é projetar interfaces ${ }^{4}$ - tangíveis ou intangíveis - entre o contexto e os indivíduos, e a da moda é expressar os códigos que dinamizam este contexto, é pertinente deduzir que as interfaces projetadas pelo design podem ser também artefatos de moda. Assim, os códigos culturais, representados nas manifestações da moda, se transformam em elementos para a configuração dos artefatos de design.

Logo, sob a premissa de que o cerne do design de $\operatorname{moda}^{5}$ é projetar artefatos vestíveis, que constituem interfaces entre as pessoas e o entorno, a plataforma teórica foi impulsionada pela ideia de que o processo projetual emerge das solicitações do contexto e finaliza submergindo, outra vez, na mesma realidade que o definiu, transformando-a e, possivelmente, influenciando novas solicitações.

\subsection{O VESTUÁRIO COMO ARTEFATO DE MODA}

Estudar o desenvolvimento de produtos de moda pode, à primeira vista, parecer um propósito demasiadamente aberto, já que a efemeridade, a mudança periódica e a valorização da novidade têm permeado diversas esferas de artefatos. Por isso, em face à diversidade de objetos que se enquadrariam na classificação de "produtos de moda", é premente definir um foco para análise, explicando, primeiramente, o uso do termo

\footnotetext{
${ }^{4}$ O termo é usado na pesquisa como a realidade/meio no qual ocorre uma interação.

${ }^{5}$ Cabe observar que no universo pedagógico estudado a expressão utilizada para referir-se ao campo da gestão do projeto de artefatos de vestuário de moda foi convencionada como "design de moda", por isso adotou-se a mesma nomenclatura no decorrer do relatório.
} 
moda na presente investigação. A tarefa não é fácil, uma vez que, o vocábulo pode gerar inúmeras interpretações, dependendo do contexto pesquisado.

Mesmo diante da heterogeneidade de conceitos, Svendsen (2010) sintetiza que, de maneira geral, se percebe duas categorias de compreensão sobre o que é moda: uma que a vincula, especificamente, ao vestuário e outra que a interpreta como um mecanismo, uma lógica ou uma ideologia geral que, entre outras coisas, se aplica ao vestuário. Embora, em suas análises, o autor se concentre em exemplos da moda de vestuário, deixa claro que a entende como algo que vai além das roupas, destacando teóricos ${ }^{6}$ que situam a moda no terreno dos fenômenos histórico-sociais. Nesta direção, discute moda de forma ampla, a partir das relações com o corpo, a arte, a linguagem e o consumo, investigando o papel plural desta nas representações sociais e, por conseguinte, na formação das identidades.

Barnard (2003) também argumenta que não há um conjunto de parâmetros rígidos que possa caracterizar uma delimitação precisa das manifestações da moda, ponderando ainda sobre a ambivalência de conceitos sobre os termos "moda" e "indumentária", os quais são usados ora como sinônimos, ora como representantes da distinção entre moda e não moda. Logo, por um lado, a moda indicaria o mecanismo social que se move continuamente, dotando as representações culturais (em especial o vestuário) de uma essência cambiante e, por outro lado, a indumentária definiria a manutenção da estabilidade de certas estruturas sociais, por meio de ornamentações corporais que reafirmam a tradição. Quanto ao foco de análise, este autor afirma que, através da moda, um grupo é capaz de se identificar e se constituir como grupo cultural, conduzindo as apreciações a respeito da moda sob o viés da comunicação.

Na mesma linha de abordagem, destaca-se Barthes (2009), que considera o vestuário como parte integrante do conjunto de instrumentos por meio dos quais o homem interfere no ambiente natural, agregando-se à cultura material e atuando na troca de informações simbólicas entre indivíduos e grupos sociais. Castilho (2004) também percebe a moda como linguagem, um sistema de signos, no qual o discurso do corpo se integra ao da moda, por meio da vestimenta, construindo representações

\footnotetext{
${ }^{6}$ Com o intuito de discutir o que a filosofia e a sociologia dizem sobre a moda, o autor analisa, entre outras, as teorias de Adam Smith, Kant, Simmel, Lipovetsky, Barthes e Benjamin.
} 
sociais que geram uma teia de significações culturais e influenciam o conceito de individualidade e de identidade.

Dirigindo a análise pela trilha da hipermodernidade ${ }^{7}$, Lipovetsky (1989) apresenta os mecanismos geradores das transformações do pensamento e de comportamentos sociais, identificando três fases históricas de organização do sistema de moda, das quais se comenta apenas a que se refere ao momento atual, uma vez que se pretende contextualizar o sistema de moda vigorante para, mais adiante, ponderá-lo na gestão do projeto de design.

A partir do estudo dessa evolução das estruturas de ordem do sistema, o filósofo chega ao conceito de moda na hipermodernidade, definindo-o por uma dinâmica de interações sociais que constituem uma forma específica de mudança na vida coletiva, que não se restringe unicamente ao vestuário, embora ele seja seu maior testemunho. Tais alterações são extremamente efêmeras e marcadas pela pluralidade das combinatórias pessoais, evidenciando uma fluidez na variação sistemática das expressões e representações dos indivíduos nos contextos sociais em que transitam. A direção proposta por este autor leva a uma ótica inovadora entre as teorias sobre a moda, pois contrapõe o conceito tão disseminado sobre a difusão verticalizada do gosto, na qual as mudanças de vestuário seriam regidas por um jogo de diferenciação e imitação entre as classes sociais dominantes e as dominadas.

Sobre este conceito, Caldas (2004) é cauteloso, afirmando que não considera completamente suprimido o "paradoxo de diferenciação-imitação", quando se investiga os sinais que indicam as novas alterações sociais, as quais levarão a novas modas $^{8}$ : as tendências. Porém, o autor reconhece que esses sinais não obedecem mais a uma hierarquia e tampouco a difusão desta se concentra em uma só fonte, concluindo que "o mercado, a sociedade, a cultura somos nós, cada um de nós" (CALDAS, 2004, p.207).

Os direcionamentos aqui enfatizados não têm o propósito de abarcar a extensa gama de enfoques das explicações sobre o fenômeno da moda, o intuito é destacar perspectivas que reforçam a diversificação de conceitos e, principalmente, conduzir a

\footnotetext{
${ }^{7}$ O autor denomina desta forma o período que sucede a modernidade, chamado por outros teóricos de pós-modernidade.

${ }^{8}$ Compreendida como fenômeno de mudança nos padrões vigentes em qualquer esfera (CALDAS, 2004, p.43).
} 
síntese das interações teóricas que guiaram a abordagem do termo na presente pesquisa. Por conseguinte, neste estudo, moda é entendida como um mecanismo multidimensional que influencia e reflete as variações de comportamentos de grupos sociais que partilham um determinado tempo e espaço ${ }^{9}$, originando modos de expressão e representação coletivas que se imbricam com as identidades dos indivíduos ali vinculados. Entretanto, como já sugerido em Lipovetsky (1989) e corroborado por De Carli (2010), o contexto pós-moderno - ou hipermoderno - exalta a autonomia e a liberdade individual para combinar estas formas de representação.

Considerando que esta investigação visa à proposição de estratégias metodológicas para a concepção de artefatos cuja aplicação se destina a um âmbito acadêmico que forma designers para a indústria do vestuário, o prisma da abordagem se afunilará aos produtos de vestuário que se inserem neste mecanismo multidimensional, aqui denominado vestuário de moda, ou seja, artefatos vestíveis altamente orientados para o mercado, com obsolescência programada e que devem contemplar, além da função de abrigo e proteção, os valores simbólicos dos códigos estéticos vigentes.

A partir desta delimitação, é fundamental esclarecer dois conceitos que se relacionam, diretamente, com as variações do vestuário de moda, o de ciclo de moda e de processo de moda. De acordo com Conti (2008), o ciclo se refere ao lapso de tempo, dividido por fases, que variam entre a introdução de uma nova moda e a sua substituição por uma moda sucessiva. Em relação ao processo, o autor define como um "conjunto de influências, interações, trocas, adaptações e sistematização entre pessoas, organizações e instituições que animam o ciclo do início ao fim." (CONTI, 2008, p. 225). Sob tais considerações, ressalta-se que os artefatos considerados nesta explanação estão sujeitos aos ciclos da moda e se concretizam por meio deste processo que envolve a integração de códigos culturais, economia, tecnologia e produção, em um determinado ambiente físico e social.

Após este olhar panorâmico sobre a conjuntura que envolve o vestuário de moda e esclarecidos os conceitos que poderiam suscitar interpretações diversas, este estudo

\footnotetext{
${ }^{9}$ A partir das indicações de Limonad (1999), que pondera os estudos de H. Lefebvre (The Production of Space), o termo espaço é compreendido como o meio e, ao mesmo tempo, resultado das interações (ações e relações) sociais, abrangendo algo além do lugar geográfico.
} 
não poderia adentrar o campo do Design de Moda sem passar pelo panorama de interações das quais seus produtos participam, tendo em vista o papel ativo da vestimenta nas relações geradas no espaço histórico-social.

\subsection{O VESTUÁRIO DE MODA COMO ESPAÇO DE INTERAÇÕES}

O conjunto de artefatos produzidos e utilizados pelos grupos sociais humanos, ao longo do tempo, é qualificado como cultura material. Todavia, conforme Faggiani (2006), a função destes artefatos vai além dos requisitos de adaptação ao ambiente físico, uma vez que envolve fatores simbólicos, psicológicos e afetivos que, por sua vez, não detêm significados fixos.

Ono (2006) concorda, afirmando que, para cada sociedade, os objetos assumem significados particulares, refletindo valores e referências culturais. Sobre esta plataforma de pensamento, constata-se que este universo de artefatos oferece inúmeras possibilidades de vivenciar o entorno, sendo o que dá forma ao espaço e instrumentaliza as trocas sociais.

Deste modo, os objetos se constituem como representações simbólicas, sobretudo quando se faz referência à tão comentada era da informação, na qual as relações com as coisas, tomando emprestado o termo de Flusser (2007), podem ser apenas veículos para as não coisas; na experiência com um artefato, o que ele diz é mais valioso do que aquilo que faz. Como explica Flusser (2007, p. 55): "nosso interesse existencial desloca-se, a olhos vistos, das coisas para as informações. Estamos cada vez menos interessados em possuir coisas e cada vez mais querendo consumir informações".

O mundo experimentado sob o intermédio destes artefatos-mensagens, os quais revelam seus conteúdos (signos culturais) por meio da forma, não é algo desconhecido dos designers que projetam vestuário de moda. Nesse campo, o aporte simbólico é claramente exaltado no processo projetual e a forma projetada é compreendida como espaço de experimentação sensorial e de significações, como explicado nos próximos parágrafos.

Considerando que, em termos de "habitáculo", a indumentária - roupas e acessórios corporais - é o mais próximo e imediato ao corpo entre os espaços habitados, 
Saltzman (2009) coloca que a existência humana, em distintos planos, está condicionada pela circulação nos inúmeros espaços, que se sucedem na integração com o entorno, organizando-se em contextos concêntricos, em que a presença e a relação com o meio estão filtradas pelas características da indumentária.

Sob tal raciocínio, resgata-se Montemezzo e Santos (2002). Ao analisar o papel do vestuário na interação homem-ambiente, argumentam que a indumentária pode ser considerada como uma "Interface Global Primária". Os autores explicam que o vestuário faz parte do meio físico/material do homem e está presente na maior parte do tempo cotidiano, funcionando como uma extensão do corpo e interagindo com o organismo de maneira generalizada e direta. Logo, pode intervir na realização das ações humanas e no relacionamento humano com quaisquer espaços.

Seguindo por este fio condutor, é clara a relação íntima e simbiótica que o vestuário pode estabelecer com o corpo que o transporta. Neste sentido, Saltzman (2008) pontua que, embora a forma que se projeta no design deste tipo de artefato seja a da roupa, por meio dela, o que realmente se modela é o próprio corpo.

Souza (2008) parte da mesma linha de análise para estudar a criação e a construção da forma por meio da modelagem tridimensional ${ }^{10}$, considerando essencial o estudo do espaço corpóreo em integração com o espaço projetado da veste. A autora afirma que o corpo humano constitui um espaço próprio, delimitado por sua estrutura morfológica, que se faz presente, ocupando uma série de outros espaços. Neste rumo, o vestuário pode ser entendido como o primeiro habitat do corpo, visto que é o primeiro espaço que este ocupa, pois na vestimenta, a matéria é manipulada em estruturas formais que contêm o espaço corpóreo. Tal argumento revela que o espaço é o objeto de planejamento do design de moda, mais propriamente um composto espacial que conecta espaço corporal, espaço da veste e espaço circundante. Saltzman (2008 apud SOUZA, 2008), aclara este pensamento ao definir esta espacialidade em interioridade e em exterioridade, espaço público e espaço privado: a superfície têxtil se expressa para o corpo e para o entorno. Para fora delimita forma, volume e silhueta, transformando a

\footnotetext{
10 Modelagem Tridimensional ou Moulage: técnica que permite desenvolver a forma da vestimenta sobre um manequim técnico, ou mesmo sobre o próprio corpo. A autora estuda e aplica a Moulage como instrumento de criação, ponderando que a experimentação tridimensional contribui fortemente para percepção e integração dos elementos técnicos, estéticos e ergonômicos na configuração de produtos de vestuário.
} 
anatomia e promovendo interfaces com o espaço circundante, e para dentro configura o habitat, um espaço particular de sensações e percepções que se antepõe às relações com outros espaços e outros corpos.

Ponderando o sistema espacial apontado por Saltzman (2008; 2009) e Souza (2008), é coerente pensar que os vínculos ali gerados situam o vestuário como uma extensão do corpo que o traja, criando uma sucessão de influências mútuas, em que a roupa se integra ao corpo, como uma segunda pele, intervindo nas vivências cotidianas e na articulação do relacionamento humano com o tempo e o espaço, constituindo-se como meio de interação social.

Por outro lado, se o referido sistema espacial for identificado com o espaço habitado, interpretado como o ambiente em que se estabelece a cultura humana e no qual a moda emerge, é perceptível que as relações se estabelecem, especialmente, no espaço construído ${ }^{11}$ : o espaço urbano. Mello (2011) ratifica este sistema de conexões no espaço construído ao estudar as interfaces comunicativas entre moda, arquitetura e cidade.

Ao projetarem ambientes que são habitados pelos corpos humanos, a moda, a arquitetura e o urbanismo podem ser compreendidos como um todo, uma vez que têm como finalidade essencial promover a adequação do indivíduo em relação ao seu ambiente através dos espaços idealizados para abrigarem os seus corpos (MELLO, 2011, p.133).

Esta conexão de espaços, visualizada como invólucros sucessivos e dinâmicos do corpo, remonta à teoria das cinco peles de Friedensreich Hundterwasser, já mencionada por vários autores, sob diversas abordagens. No presente estudo, o ponto de interesse é enfatizar o cenário social como a interação contínua e fluida entre tempo, pessoas, espaço ocupado e não ocupado. Este fluxo comunicativo viabiliza as transferências culturais e a formação das identidades, processos estreitamente ligados ao processo de design de moda.

Segundo Restany (1999 apud BATISTA, 2012; MARTINS, 2008), a espiral de Hundterwasser corresponde a cinco peles com cinco instâncias: a primeira pele como a

\footnotetext{
11 “O espaço construído tem uma dupla caracterização: de um lado, demarca as formas de apropriação do espaço urbano; de outro, estas marcas representam o elemento comum de mútuo pertencer entre o espaço e a coletividade que o dinamiza. Nesta dimensão, o design do espaço é sua apropriação e identidade social" (FERRARA, 2002, p.15).
} 
epiderme; a segunda pele como a vestimenta; a terceira pele como a casa do homem; a quarta pele como o meio social e a identidade; a quinta pele como a humanidade, a natureza e o meio ambiente. A teoria diz que as cinco peles se comunicam, simultaneamente, e a existência humana está condicionada à qualidade dos intercâmbios realizados neste sistema, conforme ilustrado na Figura 4.

Figura 4 - A espiral de Hundterwasser.

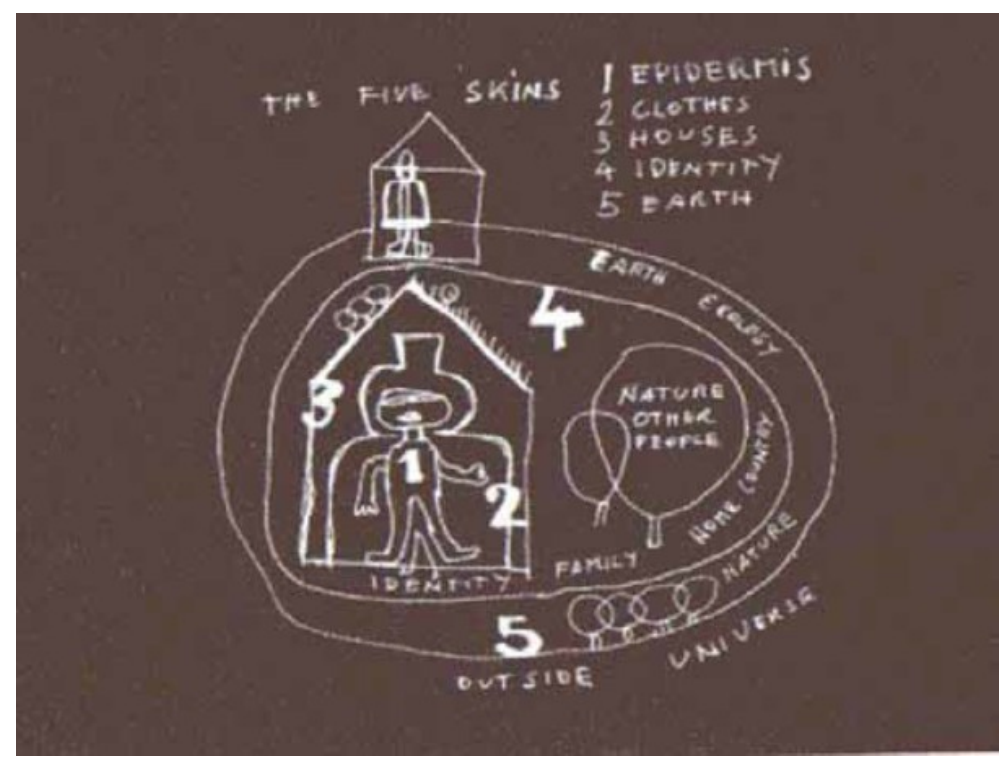

Fonte: Batista (2012)

A epiderme dá a forma, delimita e intercede na relação do entorno com o espaço do corpo, aqui considerado como entidade física e psicológica que constitui o espaço individual, o qual é, concomitantemente, transformado e transformador do sistema no decorrer da sua vida. Batista (2012) acrescenta que a primeira pele, ao delimitar o corpo, define também o espaço de construção do sujeito que, a partir da interface entre os espaços individual e coletivo, estabelece as referências para a formação da identidade.

A segunda pele, a vestimenta, por sua extrema proximidade física, mantém uma relação de extensão com a primeira, posto que a vestimenta embala o corpo anatomicamente, interferindo nas interfaces com as outras peles. Como artefato, a segunda pele se conecta com a cultura material circundante e se integra ao espaço habitado, que corresponde à terceira pele e pode ser lido como espaço construído, incluindo moradia, espaço de trabalho e não trabalho, como corrobora Martins (2008).

No encadeamento destes espaços, a vestimenta (incorporada ao sujeito) participa das trocas sociais em escalas diversas, por meio de articulações que incluem o 
âmbito familiar, geográfico, social e cultural. Essas esferas se associam na quarta pele, abrigando os espaços individual e coletivo. Assim, a quarta pele agrega o meio social e a identidade, a qual define particularmente o sujeito (primeira pele), mas também o coloca como unidade de uma coletividade humana planetária, a quinta pele, repleta de indivíduos que compartilham uma mesma pele (BATISTA, 2012; MARTINS, 2008).

Como segunda pele, a veste se adapta à estrutura morfológica do corpo, sendo modificada por ela, assim como o corpo é revestido de cores, formas e texturas que o alteram, construindo mensagens e orquestrando relações semânticas com o espaço a sua volta (SANCHES, 2007). Na mesma direção, Crane (2006) argumenta sobre o papel do vestuário como registro cultural:

[...] o vestuário é sempre significativo e em suas interpretações aproximamonos da organicidade da sociedade que o produziu. Afinal, em seus cortes, cores, texturas, comprimentos, exotismo, as roupas dão conta de imprimir sobre os corpos que as transportam categorias sociais, ideais estéticos, manifestações psicológicas, relações de gêneros e de poder (CRANE, 2006, p. 22).

Neste sistema, corpo e artefato entrelaçados se acoplam a outros espaços, em que outros corpos vestidos transitam e se integram, mesmo que temporariamente, criando uma malha comunicativa, em que se manifesta um ininterrupto e recíproco movimento de transformação do cenário social. No contexto complexo, marcado pela realidade multifacetada, híbrida e dinâmica, as significações geradas nessa malha de percepções são transitórias, por isso, cada corpo habitante ${ }^{12}$ transforma o espaço habitado ${ }^{13}$, mas também é, constantemente, transformado neste fluxo rizomático de conexões.

Castilho (2004) enfatiza o processo de significações gerado nestas vinculações, quando argumenta que a moda pode ser compreendida como expressão de um conteúdo que veicula um discurso, da mesma forma que o corpo também se expressa por meio de uma linguagem própria e, assim, quando atrelados, pode-se entender que, juntos, artefato de moda e corpo estabelecem um discurso de conteúdo conexo.

13 As expressões "corpo habitante" e "espaço habitado" foram emprestadas de Souza (2008), já que sintetizam claramente as relações que carregam. Os termos também são conceitualmente corroborados por Saltzman (2008; 2009) e Mello (2011). 
Concebendo que essa comunicação ${ }^{14}$ se estrutura, principalmente, sobre mensagens não verbais, em particular nos domínios da visualidade, Mello (2011) argumenta que, por meio das vestes, os corpos geram uma representação imagética de modos de pensar, imbricando em aparências uma imaginabilidade que tem uma linguagem semântica de comunicação imediata e coletiva.

Tal afirmação leva à evidente relevância do vestuário na produção do ambiente artificial $^{15}$ humano; como meio de adaptação física, expressão e representação, as vestes se convertem em instrumentos da construção de sentidos e registros móveis das relações de tempo-espaço incorporadas na cultura material. Essa linha de raciocínio foi desenvolvida a seguir, ao analisar o papel comunicativo do vestuário de moda.

\subsection{O VESTUÁRIO DE MODA COMO MENSAGEM}

A vida cotidiana é experimentada sob a mediação de inúmeros objetos criados pelo homem. No transcurso de um dia, os indivíduos utilizam uma diversidade de artefatos para interagir com o ambiente. As interações promovem a formação de múltiplos valores acerca do artefato em uso, valores que se estendem desde a operacionalidade até o apelo afetivo.

Em relação a este aspecto comunicativo, Baxter (1998) confirma que as propriedades do sistema visual humano determinam, em grande parte, o que é visto como qualidades atraentes em um produto, sendo a aparência visual a maior responsável por estabelecer valores emocionais. Essa preponderância do partido visual é explicada por Dondis (1997), quando relata que o contato humano com o entorno é

\footnotetext{
${ }^{14} \mathrm{O}$ termo comunicação é compreendido como o ato de estabelecer conexões por meio de processos de significação, construídos pela troca de mensagens - verbais, não verbais ou mistas. Bordenave (1996) destaca os elementos primordiais para haver comunicação: realidade, prevendo que deve haver uma situação de espaço-tempo; interlocutores, que são os sujeitos que participam do ato comunicativo, alternando as posições de fonte e receptor da mensagem; mensagem, que se refere ao conteúdo que se deseja partilhar; forma, a qual se constitui pelo modo de representação da informação; meio, que, por fim, significa o canal usado pelos interlocutores para levar a mensagem.

${ }^{15}$ Ambiente artificial se refere ao ambiente construído, ao entorno constituído pelas interfaces que o homem produz para o seu conforto e comunicação. "O homem assegura a sua sobrevivência mediante a criação de mensagens e objetos, os quais, como extensão de suas faculdades constituem a denominada "segunda natureza". Se cria, assim, um ambiente humano um entorno não inato com complementos artificiais para melhorar o entorno natural, que se acomoda às suas necessidades" (SIMÓN, 2013, p.1tradução nossa).
} 
intensificado pela experiência visual, apontando que, já nos primeiros anos da vida de uma pessoa, os estímulos captados pelo tato, olfato, audição e paladar são rapidamente superados pelo plano icônico - capacidade de ver, reconhecer e compreender, em termos visuais, as forças ambientais e emocionais.

A visão é veloz, de grande alcance, simultaneamente analítica e sintética. Requer tão pouca energia para funcionar, como funciona, à velocidade da luz, que nos permite receber e conservar um número infinito de informação numa fração de segundos (DONDIS, 1997, p.6).

De acordo com Munari (2006), toda mensagem visual tem dois componentes, informação e suporte visual, sendo a informação o conteúdo a ser comunicado e o suporte visual a forma. Este suporte é composto pelo conjunto de elementos visuais e as relações compositivas que tornam a informação visível. Contudo, há uma relação de interdependência entre o suporte visual e a interpretação da informação. Arnheim (1980) corrobora esse vínculo, enfatizando que todo acontecimento visual é composto por uma forma com conteúdo e ressalta que o conteúdo é influenciado pela importância das unidades formais e as relações compositivas com o significado.

Guardadas as devidas proporções na acepção dos termos emprestados da linguística, admite-se dizer que a semântica de um artefato pode ser construída por meio da combinação ordenada de elementos visuais, como formato, cores e texturas, estabelecendo um sistema de signos. Logo, é pertinente pensar que há um raciocínio de sintaxe para relacionar esses elementos em códigos $^{16}$ reconhecíveis, dando forma ao conteúdo da informação.

Desta perspectiva, o vestuário de moda é um importante veículo de processos comunicativos, uma linguagem, como sancionam Castilho (2004) e Oliveira $(2005 ; 2007$; 2011), sobretudo pelo canal não verbal. Isso conduz, naturalmente, a presente explanação pelos caminhos da comunicação visual, inferida no presente contexto como o processo de interação entre signos não linguísticos, especificamente os que se pronunciam na composição plástica da forma visual de artefatos. Coelho (2008)

\footnotetext{
${ }^{16}$ Código é entendido como um sistema de signos que se articulam sob certas convenções para formular e compreender uma mensagem. Em se tratando de moda, como linguagem não verbal, os códigos não se apoiam em convenções de regras fixas ou estruturas lineares para a articulação dos signos que compõem o artefato. Os códigos neste campo são construídos a partir dos padrões culturais/comportamentais e as manifestações estético-visuais recorrentes.
} 
recomenda que este tipo de comunicação, quando estudado em função do projeto de um artefato, deve ser considerado como um dos propósitos inerentes ao design, definindo que projetar a comunicação visual significa "estabelecer qual a melhor maneira de transmitir visualmente um determinado conteúdo" (COELHO, 2008, p.142). Contudo, o autor enfatiza os elementos culturais como determinantes dos significados possíveis para as diversas formas visuais de comunicação.

De acordo com Cardoso (2012), os conceitos simbólicos que são atribuídos a um objeto, em realidade, não são qualidades fixas, tampouco derivam diretamente da configuração física, mas de um repertório cultural e de pressupostos, ou seja, o significado é construído pela integração da percepção humana, com o tempo, o espaço, a cultura e a memória.

As formas dos artefatos não possuem um significado fixo, mas antes são expressivas de um processo de significação - ou seja, a troca entre aquilo que está embutido em sua materialidade e aquilo que pode ser depreendido delas por nossa experiência (CARDOSO, 2012, p. 35-36).

Pelo exposto, seria um equívoco acreditar, por exemplo, que uma cor pode ter um significado conato, em que o aspecto material e o conteúdo mantêm um vínculo original, uma relação não arbitrária. Como já mencionado, os significados são gerados pela associação da percepção com o repertório construído pela cultura, a vivência espacial e a memória, por isso é impraticável estabelecer algum grau de comunicação em um universo sem a identificação e o conhecimento dos signos de representação cultural que se organizam ali.

\begin{abstract}
A comunicação é uma função do código e do repertório, que, por sua vez, estão na dependência da informação. [...] O grau de imprevisibilidade dos sinais - da informação, portanto, vincula-se à capacidade de manipulação do código (PIGNATARI, 1971, p. 42 apud CONTANI, 1998).
\end{abstract}

Toda a arguição anterior demonstra a estreita relação entre as dimensões sintática e semântica de um produto. Contudo, para a efetiva transposição de conteúdo ${ }^{17}$ (informação visual) para a forma, é essencial compreender os conceitos de sintaxe e semântica entre as dimensões atuantes na configuração de um produto. Estas

\footnotetext{
${ }^{17}$ A relação entre a forma e o conteúdo no vestuário será explorada, em tópico posterior, nas análises sobre os fatores atuantes no planejamento da sintaxe da configuração de um produto de vestuário de moda.
} 
dimensões foram explicadas por Niemeyer $(2003)^{18}$, juntamente com as dimensões material e pragmática, conforme resumido a seguir.

A) Dimensão material: se constitui pelas propriedades materiais do artefato, a sua materialidade em si. Niemeyer não a explora isoladamente, salientando que o aspecto hílico será mais bem entendido como elemento comunicativo, quando articulado com as outras dimensões. Abrem-se parênteses para comentar e estabelecer um vínculo de pensamento sobre essa articulação. Flusser (2007, p.28), no seu ensaio sobre forma e material, apresenta o design como um processo que pode dar forma à matéria e fazê-la aparecer como aparece, logo pode-se pensar que a materialidade, como substância formada e transformada, informa, ou melhor, representando o conceito, informa.

B) Dimensão sintática: referente à estrutura e ao funcionamento técnico do artefato. A estrutura consiste nas partes do produto e o modo como se conectam, incluindo construção técnica e detalhes visuais, os quais também são descritos como aspectos da composição formal, abrangendo elementos visuais compositivos e procedimentos relacionais ${ }^{19}$. Gomes (2006) também elucida esta dimensão sob o mesmo princípio de ordenação dos elementos que se articulam para formar e informar.

C) Dimensão pragmática: versa sobre o uso prático (utilidade) do produto, considerando todo o ciclo de vida deste; apreende o conjunto de relações que o produto estabelece com o usuário no campo ergonômico ou sociológico (quem usa e em que situação é usado). Gomes (2006) destaca que envolve a relação entre os signos (produto) e seus intérpretes (usuários).

D) Dimensão semântica: concentra as qualidades expressivas e representacionais, sendo a dimensão que agrega aspectos de referência à

\footnotetext{
18 A autora baseia as definições destas dimensões nos estudos de BENSE, Max (1971) - Pequena Estética. * As dimensões Sintética, pragmática e semântica foram cunhadas por Charles William Morris em 1970, em sua análise sobre as dimensões da semiose.

19 Segundo OLIVEIRA (2005), as relações, articulações ou regras de combinação entre os elementos de uma composição visual são denominadas procedimentos relacionais.
} 
dimensão sintática e material, seus descritores. Trata de como o produto sugere, por meio da composição formal, as qualidades de uso ${ }^{20}$.

Tais dimensões foram isoladas para fins didáticos, mas Niemeyer (2003) alerta que as dimensões semióticas de todo artefato se constituem simultaneamente (Figura 5) e articulam qualidades representacionais em conjunto, uma vez que os significados são cunhados por meio da percepção conjugada de tais dimensões, mediante a experiência vivenciada com o produto em um determinado contexto. Consequentemente, ainda que esta pesquisa esteja centralizada no recorte que trata da dimensão sintática e de sua influência na dimensão semântica, a composição da forma do vestuário é resultante da coordenação das propriedades da matéria, dos requisitos de uso, dos referenciais estético-simbólicos e dos parâmetros de adaptação para o conforto corporal. Somente por meio da interação desses fatores é que se expressa alguma informação coerente.

Figura 5 - Exemplo ilustrativo das quatro dimensões semióticas do produto.

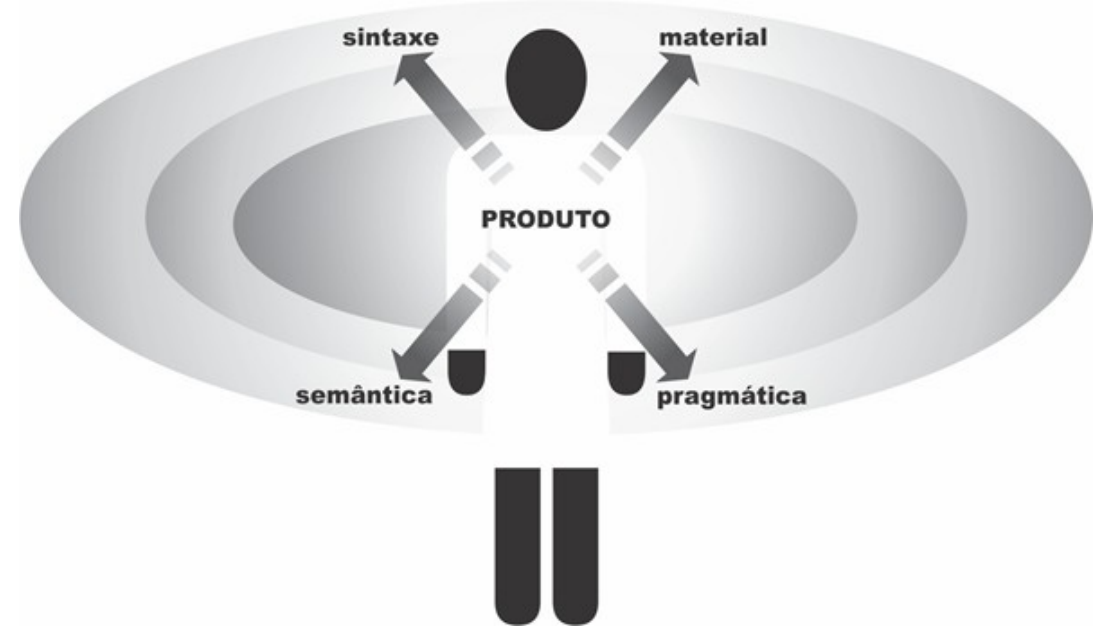

Fonte: Elaborado pela autora, com base em Niemeyer (2003).

Segundo Niemeyer (2003) o modo como um produto é sentido decorre do julgamento de percepção a que é submetido. Então, face à estrutura mental, o indivíduo pode reagir ao produto. Esse processo é estudado por várias áreas do conhecimento, entre as quais está a semiótica, na qual se buscaram fundamentos que ligassem este

\footnotetext{
20 Inclui o uso prático, social e estético.
} 
campo ao design e à moda, sem a menor intenção de dissecar conceitos ou comparar diferentes teorias, que apesar de muito interessantes, não vêm ao caso neste estudo. 0 cerne da questão é constatar que um artefato de vestuário pode atuar como mensagem ${ }^{21}$ e, então, considerar esta dimensão no processo projetual do design de moda para planejar a sintaxe da forma.

Ao ponderar as reflexões de Niemeyer (2003), sobre design e semiótica, e de Castilho (2004) e Oliveira (2007; 2011), sobre moda e linguagem, admite-se que, como produto, a configuração do vestuário de moda carrega informação sobre os seus próprios atributos, além dos enunciados do corpo e da moda, representando também a si mesmo, o que lhe confere uma sucessiva articulação sígnica.

Para melhor compreensão, se esclarece, conforme orienta Santaella (1990), que o "signo é uma coisa que representa uma outra coisa: seu objeto. Ele só pode funcionar como signo se carregar esse poder de representar, de substituir uma outra coisa diferente dele". Logo, signo não é o objeto - o algo representado -, só está no lugar do objeto. Em outras palavras, um signo representa alguma coisa para alguém em determinada circunstância. Cabe realçar que a representação é a qualidade principal do signo, contudo os significados que esta produz dependem do repertório cultural do intérprete. Os signos têm vínculo cultural e seus objetos de referência são unidades culturais e, como tal, a interpretação depende da associação aos costumes, às tradições, aos valores ou aos códigos de linguagem do contexto no qual se inserem.

Desta perspectiva, fica claro que um artefato não vai gerar associações coincidentes se for deslocado em ambientes culturais distintos. Não obstante, no mundo globalizado, as variações da moda são percebidas no tempo e não tanto no espaço, isto é, as mudanças ocorrem em um tempo muito veloz, mas em relação ao espaço pode parecer que o mundo todo se contamina em uma homogeneidade. Se por um lado é verdade que a disseminação globalizada das modas parece assemelhar o mundo, por outro lado, não significa que o mesmo artefato (ou a mesma sintaxe de elementos formais) será percebido e interpretado da mesma maneira, sendo bem

\footnotetext{
21 “[...] mensagem aqui não diz respeito apenas àquilo que sai de uma fonte e atinge um receptor graças à existência de um código previamente constituído; trata-se de um processo dinâmico de significação que implica tanto a operação conjunta entre fonte e recepção para codificar a informação, quanto a variedade de códigos que entram em ação no processo de recodificação" (MACHADO, s.d.).
} 
provável que não, tendo em vista que o deslocamento de contexto pode gerar associações com outras unidades culturais.

Exposto o terreno de multiplicidade e mutabilidade pelo qual transita a moda, pressupõe-se, de acordo com Castilho (2004), que a moda possui um vasto repertório paradigmático, o que significa que ela oferece uma ampla possibilidade de elementos a serem escolhidos e combinados. Tais combinatórias são compostas pela seleção de um elemento, entre as opções disponíveis em uma categoria de elementos similares, seguida pela união com outros elementos, extraídos de categorias distintas. Assim, será formado aquilo que é denominado sintagma. Para aclarar, Pignatari (2005) sintetiza que o eixo paradigmático está ligado à organização por similaridade, envolvendo a ideia de seleção/modelo, enquanto o eixo sintagmático se vincula à ordenação por contiguidade, implicando em reunião/combinação. Partindo destes parâmetros e ilustrando a relação entre paradigma e sintagma no âmbito estudado, o exemplo a seguir demonstra o movimento cíclico estabelecido no jogo de combinatórias da moda.

Se, em um dia de clima frio, uma pessoa escolhe um blazer preto, entre as possibilidades de peças para agasalhar o tronco (paradigma 1), combinando-o com uma calça preta, selecionada entre as várias possibilidades de calças (paradigma 2) e assim, sucessivamente, vai selecionando e unindo outras peças de roupa (ou acessórios) a este conjunto, este indivíduo estará compondo o seu "sintagma vestimentar" (CASTILHO, 2004, p.37). Entretanto, se for ampliada a reflexão, esta combinatória poderia ser uma repetição de um sintagma preestabelecido? Uma seleção entre as várias possibilidades de combinações clássicas, com blazer preto, previstas pelos paradigmas da moda. Mesmo assim, se especularia que a partir daquela composição preconcebida o sujeito formou um sintagma pessoal, quando o interpretou a partir dos paradigmas disponíveis em seu guarda-roupa e das relações particulares que tem com o seu corpo e o meio cultural em que se insere. Neste rumo, é possível desmembrar o raciocínio indefinidamente, por isso, o que se pretende ressaltar é o ciclo contínuo entre paradigmas e sintagmas, constituídos na integração dos universos individual e coletivo. Esta rede de influências, mediada pelas mensagens do vestir, foi sintetizada na Figura 6. 
Figura 6 - A rede cíclica de paradigmas e sintagmas produzidos no sistema de moda

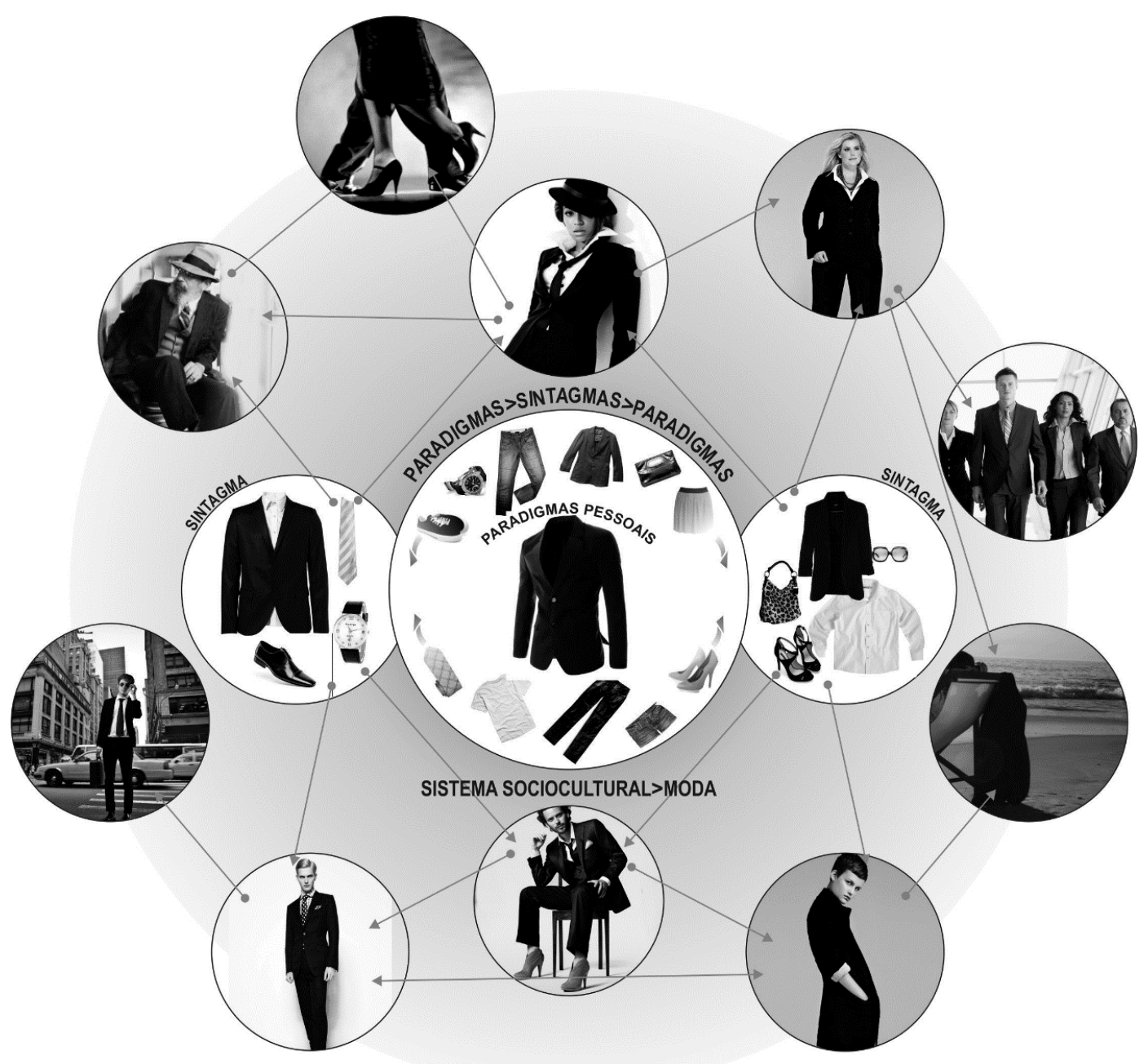

Fonte: Elaborado pela autora- Acervo pessoal (2011)

Transportando estes conceitos para o campo do projeto de design, Niemeyer (2003) afirma que o perfil de um produto se forma entre os eixos paradigmático e sintagmático, tendo em vista que, para cada elemento definido no eixo sintagmático, houve um processo decisório para selecioná-lo entre as várias possiblidades previstas no eixo paradigmático. Cada aspecto da configuração passa por tal processo, resultando em uma determinada ordenação sintática da forma do produto.

Portanto, estabelecer um canal de comunicação, por meio da dimensão formal do vestuário de moda, significa projetar de modo coerente a ordenação (sintaxe) dos elementos configurativos, para que esta se integre ao fluxo de códigos vigentes no contexto do usuário e, por conseguinte, sejam reconhecidos, assimilados e, finalmente, construídos como valores simbólicos. Para isso, é necessário codificar o artefato em 
sistemas de signos reconhecíveis, pelo que se prevê imperativo identificá-los entre as unidades culturais presentes no contexto em que o produto será inserido.

Niemeyer (2003) explica que esse processo de comunicação envolve dois elementos ativos: gerador (designer/empresário) e interpretador (usuários e sujeitos que não são usuários finais, mas estão implicados no trajeto da mensagem, na comercialização e na difusão). Para a autora, gerador e interpretador alternam as posições, pois, com sua reação, "o interpretador passa a produzir mensagens, que por sua vez são processadas (ou não) pelo gerador" (NIEMEYER, 2003, p.23). O gerador é responsável pela escolha das estratégias.

O sucesso da comunicação está diretamente ligado à habilidade do gerador (designer/empresa) do enunciado formal/visual para manipular os elementos sintáticos ${ }^{22}$ na concepção destes objetos. Sanches (2007) confirma que a competência para manejar a linguagem visual é indispensável aos designers que pretendem articular códigos simbólicos no planejamento das interfaces que projetam, proporcionando experiências cognitivas a partir do uso de tais artefatos.

Krippendorff (1989) e Krippendorff e Butter (2007) defendem que projetar é dar sentido. Para que a forma seja mediadora de significações, o processo projetual se encarrega de antever relações semânticas que possam ser atribuídas ao artefato nos contextos para os quais se destina.

Mesmo que a interpretação do conteúdo não seja permanente e esteja circunstanciada por repertórios individuais e contexto, as percepções de sentido provocadas pelo artefato se efetivarão apenas se o suporte formal/visual estiver organizado, de modo a estimular associações peculiares aos universos em que transitam os usuários interpretadores ${ }^{23}$.

\footnotetext{
22 “A sintaxe visual existe. Há linhas gerais para a criação de composições. Há elementos básicos que podem ser aprendidos e compreendidos por todos os estudiosos dos meios de comunicação visual, sejam eles artistas ou não, e que podem ser usados, em conjunto com técnicas manipulativas, para a criação de mensagens visuais claras. O conhecimento de todos esses fatores pode levar a uma melhor compreensão das mensagens visuais." (DONDIS, 1997, p.18)

23 Já foi pontuado que a transmissão de uma mensagem trata de um processo dinâmico que implica tanto a operação conjunta entre fonte e recepção para codificar a informação quanto a variedade de códigos que entram em ação no processo de recodificação. Assim, não se restringe ao circuito da codificação / descodificação; mas sim da codificação-descodificação-recodificação como atividade processual dialógica sem a qual não se pode falar em mensagem (MACHADO, s.d.).
} 
Portanto, para estudar ferramentas que facilitem o projeto do vestuário de moda, foco desta pesquisa, é premente que este tipo de produto seja reconhecido como um enunciado não verbal, que se integra às mensagens do meio em que se insere, promovendo um processo de identificação e transferência de significados. Essa tarefa só obterá êxito se for auxiliada pelo conhecimento de diretrizes para organizar e harmonizar os elementos formais, extraindo-os do entorno e transpondo-os para o planejamento do partido comunicacional do artefato. Com o intuito de proporcionar meios para estabelecer tais diretrizes, a seguir examina-se o processo de delimitação projetual no Design de Moda.

\subsection{O VESTUÁRIO DE MODA COMO FORMA}

A forma do vestuário de moda é concretizada e refinada, ao longo do processo projetual, a partir da experimentação integrada de aspectos construtivos, produtivos e de interação (física e psicológica) humana. Todavia, essa efetivação depende da delimitação de critérios norteadores para impulsionar a geração de soluções formais. Por isso, este tópico insere uma visão panorâmica sobre os fatores que direcionam o projeto de design no campo da moda, examinando os aspectos que derivam a sintaxe da forma como suporte do enunciado visual.

Antes de expor tal discussão, como esta pesquisa conecta fundamentos do design e da comunicação não verbal visual, dois campos em que o vocábulo forma tem grande importância, foram tomadas algumas decisões sobre as terminologias usadas, para evitar confusões de interpretação.

Entre os autores que estudam os elementos constitutivos da linguagem visual, desvendando as unidades da sintaxe visual, Wong (1998), ao relacionar a forma com volume e espaço, apresenta faceta que aproximam o conceito de forma dos enfoques desta pesquisa. Para ele, a forma não é apenas uma figura que é vista, mas compreende um formato ${ }^{24}$ de tamanho, cor e textura definidos, constituindo um conjunto de

\footnotetext{
${ }^{24}$ Tudo o que vemos é experimentado em relação a seus limites externos. Se não pudéssemos relacionar sinais visuais com um formato, em outras palavras, com uma superfície, um espaço, ou uma limitação temporal- o nosso cérebro não estaria apto a interpretar nenhuma dessas impressões (tradução nossa) (LEBORG, 2006, p.16).
} 
elementos inter-relacionados sobre uma estrutura de organização. Nesta acepção, dois pontos são essenciais: a concretude e um sistema de relações.

No campo do design, Cardoso (2012) argumenta que o termo forma abrange três aspectos inter-relacionados inseparáveis: a) aparência, aspecto perceptivo por um olhar; b) configuração, no sentido composicional, de arranjo das partes; c) estrutura, referente à dimensão construtiva. Neste sentido, atribui-se à forma de um objeto uma qualidade sensorial ampliada, que não se percebe em um único plano de visualização. Para percebê-la há uma confluência de aspectos de superfície, volumetria, contorno, espaço e ponto de vista. Como entidade de dimensões múltiplas e interdependentes, o autor destaca o papel expressivo e informacional da forma, produzido especialmente pela percepção visual.

Desta perspectiva, encontra-se pertinência com o que Bomfim (2014a; 2014b) denomina figura, definida pelo autor como o resultado do processo de configurar um objeto, sendo o conjunto de aspectos do objeto que se pode perceber sensorialmente, imaginar e representar. A figura é concretizada por elementos como material, forma geométrica, textura, cor, etc. Löbach (2001) também usa o termo figura para se referir ao composto da configuração, destacando, entre os elementos configurativos, a forma (formato), o material, a superfície e a cor. Para ele: “[...] a forma espacial ${ }^{25}$ de um produto industrial sempre pode ser interpretada de modo multidimensional, correspondendo às diversas apresentações da configuração ao processo de percepção." (LÖBACH, 2001, p.162). Löbach (2001) assinala que tais elementos atuam de modo integrado, em uma distribuição e ordem interdependentes que influem na percepção da informação estética ${ }^{26}$ do produto. Assim, as características estéticas da configuração de um produto são determinadas pelos seus elementos configurativos, os quais são

\footnotetext{
25 Lobach (2001) classifica dois aspectos da forma de um produto: forma espacial: forma tridimensional, determinada pela evolução da superfície, varia ao se girar o produto e produz percepções distintas ao se observar de ângulos distintos; forma plana: obtida pela projeção do produto sobre o plano, determinada pelo contorno. Permanece constante diante da variação do ponto de observação, a exemplo de uma ilustração bidimensional.

${ }^{26}$ Lobach (2001, p. 156) define estética como a "ciência das aparências perceptíveis pelos sentidos (por exemplo, a estética do objeto), de sua percepção pelos homens (percepção estética) e sua importância para os homens como parte de um sistema sociocultural (estética de valor). Pode-se acrescentar também a teoria da produção estética do homem (estética aplicada)." "Na estética do objeto se descrevem as características visuais do objeto e suas qualidades." O autor acrescenta ainda a estética empírica, na qual se faz pesquisa sobre valores estéticos em grupos determinados de pessoas, contribuindo com conhecimentos aplicáveis ao projeto de design.
} 
portadores da informação estética. A seleção de tais elementos e a articulação das relações entre eles definirá um conjunto informativo, por meio do qual será articulada a reação que o usuário terá perante o produto.

Lessa $(2009$, p. 75$)$ coloca que a forma, seja ela "física" ou "virtual", se efetiva pela ocorrência de relacionamento formal entre os componentes de um artefato, apresentando-se como espaço de diferenciação/caracterização sensorial em um ambiente de vivência em que se definem campos perceptivos. "E pode efetivar-se em várias escalas: da manipulação fina de um telefone móvel ao deslocamento em espaços geográficos amplos". Assim, a síntese da forma envolve relações/caracterizações sintáticas e semânticas e a consolidação pragmática dos componentes definidos por essas relações/caracterizações, distinguindo-se segundo o tipo de artefato projetado.

Pelo exposto, sobressaem qualidades fundamentais para a palavra forma nesta investigação: materialidade; interação entre superfície, espaço e volumetria; sensorialidade e percepção visual-estética; capacidade informativa. Acrescentando que o objeto de planejamento do Design de Moda é o sistema espacial que conecta espaço corporal, espaço da veste e espaço circundante, é pertinente deduzir que a forma/configuração do vestuário se constrói entre superfície (matéria, cor e textura), volume, contorno, interioridade, exterioridade, espaço ocupado e não ocupado.

Neste sentido, Souza e Menezes (2011) afirmam que a construção da forma do vestuário, que é fundamentalmente uma forma têxtil, está atrelada à articulação entre corpo-suporte, silhueta ${ }^{27}$, material têxtil, recursos construtivos e o próprio espaço delimitado. Logo, qualquer que seja o resultado formal, este está atrelado às decisões tomadas em relação aos materiais, a função, aos esquemas de construção e de efetivação produtiva.

Com base nas considerações elencadas, o termo forma, nesta pesquisa, é entendido como um composto material/estético ${ }^{28} /$ informacional. Compreende o conjunto de relacionamentos entre os componentes configurativos de um artefato,

\footnotetext{
27 O termo silhueta, muito difundido no campo da moda, compreende, de acordo com Souza e Menezes (2011, p.83), "a configuração morfológica e volumétrica ao redor do corpo, que define seu contorno".

${ }^{28}$ A concepção contemporânea de estética, de acordo com Oliveira (2011), evoca a ideia de perceber por meio dos sentidos. Não se trata de um conceito voltado para a percepção por meio da harmonia e do equilíbrio, pautado nos princípios clássicos da beleza, mas sim um conceito centrado nas inquietações determinadas pela experiência estésica.
} 
experimentado sensorialmente em múltiplas dimensões e percebido como expressão de informação visual. Assim, forma e configuração, quando usados como atributo de artefato (produto), no decorrer do texto, têm o mesmo sentido.

Sob este preceito, o projeto se ocupa do configurar (BOMFIM, 2014a) e significar (KRIPPENDORFF, 1989, p.14): "algo deve ter forma para ser visto, mas deve fazer sentido para ser compreendido e utilizado". Essa afirmação é essencial para definir a abordagem paradigmática atual do processo projetual, não mais enfocando o objeto, mas o ser humano e a rede de relações com um contexto sociocultural (KRIPPENDORFF, 1989; KRIPPENDORFF; BUTTER, 2007; MANZINI, 2015).

Seguindo esta orientação, abordam-se, em um primeiro momento, as dimensões da experiência de uso do vestuário de moda (forma sentida e percebida), para então discutir o processo de sintaxe da forma como veículo expressivo (forma projetada).

\subsubsection{FORMA SENTIDA E PERCEBIDA}

Alguns argumentos já traçados anteriormente são bons pontos de partida para esta explanação. Em primeiro lugar, o vestuário de moda é veículo para vivenciar o entorno. Como meios de adaptação física, expressão e representação, as vestes se convertem em instrumentos da construção de sentidos e registros móveis das relações de tempoespaço incorporadas à cultura material.

Em segundo lugar, o vestuário como segunda pele, ou "Interface Global Primária" (MONTEMEZZO; SANTOS, 2002), integra um conjunto de camadas espaciais sucessivas. Voltando a Saltzman (2008) e Souza (2006; 2008), que exploram a ideia do primeiro habitat, destaca-se os conceitos de interioridade e exterioridade, espaço público e privado, para explicar que a superfície têxtil, ao delimitar forma, volume e silhueta, simultaneamente, transforma a anatomia e promove interfaces com o espaço circundante, se configurando como um espaço particular de sensações e percepções que se antepõe às relações com outros espaços e outros corpos.

Assim, o primeiro espaço de interações a considerar é o que se constitui na vinculação das materialidades do corpo e do artefato. Planejar essa relação consiste em 
configurar o vestuário de moda em termos ergonômicos ${ }^{29}$, o que é, antes de tudo, o estudo de um sistema espacial de camadas interativas.

Ao entender a relação de uso como uma experiência ampliada, infere-se que a delimitação de quesitos de adaptação e percepção no Design de Moda extrapola o dimensionamento antropométrico e a regulação térmica, já que é necessário considerar as ligações recíprocas no sistema corpo-vestuário de moda-ambiente. Montemezzo (2003), analisando a relação de uso do vestuário, elenca os elementos básicos que podem afetar essa experiência, os quais devem ser preocupações inerentes à conduta projetual (Quadro 3).

Quadro 3 - Preocupações com a ergonomia no consumo (processo de uso)

\begin{tabular}{|c|c|c|}
\hline \multicolumn{2}{|r|}{ Proporcionar ao usuário: } & Através de cuidados com: \\
\hline \multicolumn{2}{|c|}{ Segurança } & $\begin{array}{l}\text { Matéria-prima, modelagem e aviamentos. } \\
\text { (materiais que não provoquem ferimentos e danos ao ambiente) }\end{array}$ \\
\hline \multirow{5}{*}{$\begin{array}{l}\stackrel{0}{t} \\
\stackrel{0}{0} \\
\stackrel{\leftarrow}{0} \\
ن\end{array}$} & Liberdade de movimentos & Matéria-prima, modelagem e antropometria. \\
\hline & Conforto tátil & Matéria-prima, modelagem e acabamentos. \\
\hline & Conforto térmico & Matéria-prima, modelagem e acabamentos \\
\hline & Conforto visual & Aspectos perceptivos/ estéticos/ composição visual \\
\hline & Bem-estar emocional & Exploração de valores subjetivos/ carga sígnica \\
\hline \multirow{4}{*}{\multicolumn{2}{|c|}{ Facilidade de manuseio e uso }} & Matéria-prima de fácil manutenção \\
\hline & & $\begin{array}{l}\text { Funcionamento dos dispositivos diretos de interação } \\
\text { (fechos, regulagens, elementos destacáveis, etc.) }\end{array}$ \\
\hline & & Dispositivos de informação sobre uso e manutenção \\
\hline & & Função objetiva do produto \\
\hline
\end{tabular}

Fonte: Montemezzo (2003)

Montemezzo (2003) não explora especificamente as questões expressivas ou de significação na relação de uso, mas corrobora que, ao revestir o corpo, o vestuário se torna mediador de mensagens ao ambiente, ressalta a influência dos fatores intangíveis no desenvolvimento projetual e, por consequência, a relevância do contexto

${ }^{29}$ Abordar as interações com o usuário inevitavelmente leva aos conceitos da ergonomia, tendo em vista que ela está na base da usabilidade e estuda meios de garantir que as interfaces projetadas se adaptem e proporcionem bem-estar ao homem. 
sociocultural para a configuração. Esta questão também é confirmada por Souza (2006), que marca o fator estético-simbólico e a agradabilidade visual como quesito de conforto psicológico.

Sobre a plataforma da ergonomia, pode-se inferir que os produtos estudados estabelecem uma interface vestível (entre corpo e ambiente), mediando "interações físicas e psíquicas" (MONTEMEZZO; SANTOS, 2002). As interações podem estabelecer vínculos afetivos, resultantes da experiência sensória, filtrados pelo repertório cognitivo do usuário e balizados pelo contexto sociocultural. Deste prisma, projetar o vestuário de moda significa planejar espaços que se influenciam mutuamente, se apoiando especialmente no uso social. Logo, ao delimitar que requisitos o projeto deve atender, é importante considerar as percepções do usuário sob uma visão holística, na qual o conceito de ergonomia se amplia, estendendo-se das adaptações físicas até os benefícios afetivos.

Jordan (2000) ressalva a importância do prazer na criação e no uso de artefatos. Seus estudos conceituam prazer a partir dos benefícios emocionais, hedônicos e práticos, gerados na interação com os sistemas cotidianos. Nesta abordagem, o foco do projeto é expandir a satisfação do usuário. Para isso, é primordial agregar experiências agradáveis à usabilidade. Porém, a agradabilidade não é simplesmente uma propriedade do produto, mas o resultado da interação deste com o seu usuário.

Mont'alvão (2008) reforça que o foco da ergonomia no projeto de design é o usuário. Por isso, os aspectos de efetividade, eficiência e satisfação, sobre os quais se define usabilidade, deveriam abranger também os benefícios emocionais. De tal modo, o estudo do sistema de interações se dilatará e os artefatos projetados serão atrativos, amigáveis e prazerosos. A autora enfatiza o conceito de Hedonomia, sob o qual, depois de satisfeitos os quesitos de funcionalidade e usabilidade, o projeto visa alcançar a satisfação das necessidades psicológicas e sociológicas do usuário, tornando prazerosa a experiência de uso. Destarte, o valor afetivo é inerente ao contexto projetual e se torna fundamental considerá-lo como critério de delimitação projetual na ergonomia de concepção.

Apoiado na teoria dos prazeres do antropólogo Lionel Tiger, Jordan (2000) distribui o prazer humano em quatro níveis: 
A) Fisiológico: derivado dos cinco sentidos humanos.

B) Social: vinculado às relações interpessoais, à identidade e ao status social, favorecido por produtos e serviços que promovem interação social.

C) Psicológico: vinculado às reações emocionais e cognitivas das pessoas associadas às reações emocionais advindas da experimentação dos produtos.

D) Ideológico: ligado ao repertório de valores das pessoas, incluindo gostos e crenças; refere-se à identificação com a aparência dos artefatos e com os valores que eles representam.

Para dar corpo à reflexão anterior, é valioso resgatar as pesquisas de Norman (2008), que identificam os níveis de processamento cerebral dos sistemas cognitivo e emocional, definindo três níveis de design: visceral, comportamental e reflexivo. 0 primeiro nível estaria centrado na aparência do objeto, provocando uma reação imediata e puramente emocional, quando um indivíduo diz "Eu quero", mesmo antes de saber qual o uso prático que fará do artefato. No nível comportamental, o foco é "O que faz?", logo, a eficácia na realização da função básica (ou prática) é o que importa. 0 último nível, mais complexo, envolve o sentido que um objeto produz na relação de uso; relaciona-se às mensagens que este transmite e, por isso, está intrinsecamente ligado à cultura e aos códigos comunicativos que permeiam o universo do usuário; diz respeito, à autoimagem e às mensagens que o artefato emite. Na linha de raciocínio de Normam (2008), é coerente deduzir que, embora estes níveis não atuem isoladamente, pelo entendimento de seus processamentos se compreende a relevância expressiva e perceptiva do vestuário de moda, fortemente atrelado aos conceitos de emoção e prazer.

Press e Cooper (2009) confirmam que, nas sociedades contemporâneas, o papel do designer é entender o design como um processo de decisões que gera experiências significativas para os usuários, conectando-se à vida cotidiana. Estes autores defendem a relação de uso como um processo de experiências tangíveis e intangíveis - sensações, sentimentos, desejos, aspirações e relações sociais - que surgem da interface com o entorno projetado. O raciocínio destes autores sanciona o papel da vestimenta como 
mediador de um enunciado não verbal que se integra às mensagens do meio. Neste, a forma sentida é também forma percebida ${ }^{30}$ e comunicante.

À luz dos conceitos destacados, ratifica-se que a materialidade da forma experimentada sensorialmente, em âmbito individual e coletivo, atende finalidades de adaptação física, expressão individual e representação social. Estes parâmetros são a base para estudar a forma do vestuário de moda e indicam que as variáveis projetuais realçam os aspectos subjetivos e comunicativos, como argumentado na próxima explanação.

\subsubsection{FORMA PROJETADA}

Bonsiepe (2012) defende que o design se encontra na interseção entre a cultura da vida cotidiana, da tecnologia e da economia. O autor ressalta que, para cumprir o papel de otimizar a relação entre artefato e usuário, é fundamental considerar também a qualidade visual do produto, interpretando-a como algo arraigado e inseparável da estrutura subjacente do artefato. Isto é, uma vez que as necessidades humanas são determinadas pela cultura, não existem necessidades materiais isoladamente, por isso a qualidade visual é constituída a partir da integração indissolúvel de necessidades materiais e psicológicas.

Lessa (2009) alerta que a "enunciação ${ }^{31}$ projetual" deve sempre levar em conta os parâmetros formais/visuais dados pelo conjunto de todos os equacionamentos do

\footnotetext{
30 lida (2005) explica que sensação se refere ao processo biológico de captação do ambiente, por meio dos órgãos sensoriais. Em contrapartida, a percepção é o resultado do processamento do estímulo sensorial, dando-lhe um significado. "Os estímulos recebidos são organizados e integrados em informações significativas sobre objetos e ambiente. Nesse processo são usadas informações já armazenadas na memória para converter as sensações em significados, relações e julgamentos." (IIDA, 2005, p.258)

31 Lessa (2009) utiliza o conceito de enunciação de Émile Benveniste, para referir-se ao processo de construção do ato comunicativo. Sob esta ótica, o discurso se produz na linguagem em uso, a partir de um locutor que se apropria da língua (e de suas características sintáticas) para enunciar sua posição, a qual é marcada por combinatórias linguísticas específicas, influenciadas pelas suas referências individuais e contextuais. "A enunciação converte a língua (código) em discurso pelo emprego que o locutor faz dela. Desse modo, a língua se semantiza." (BARBISAN, 2007, p.26). Entende-se então, que a totalidade do projeto é vista como "enunciação projetual", na medida em que compreende o processo de construção do enunciado (artefato); neste âmbito a enunciação formal/visual diria respeito à efetivação do artefato em termos da linguagem formal/visual e dependeria de combinatórias específicas, que equacionam vários fatores. Contudo, Lessa (2009) é cauteloso com os termos linguísticos e não usa o a expressão "discurso
} 
projeto. As formatações utilitárias, as condições tecnológicas e humanas, entre outras, consolidam formas e visualidades, as quais se colocam como referências para o projeto. Logo, a forma de um artefato se efetiva pela associação entre vários equacionamentos: expressivos, utilitários; operativos/ interativos (ergonômicos); tecnológicos; de efetivação produtiva; mercadológicos (público-alvo, esquemas de distribuição/transmissão/comercialização); gestão de imagem (comunicação e posicionamento de marca); éticos (responsabilidade socioambiental). Os argumentos do autor reforçam a ideia da forma construída a partir de uma convergência de fatores, sintetizados com base na identificação de necessidades e objetivos.

Se a qualidade expressiva do artefato é dada pela forma, a partir dos equacionamentos anteriormente enumerados, é pertinente inferir que esta representa a evidência concreta do conceito ${ }^{32}$ do artefato (LESSA, 2009, p. 84) e que ela só se efetiva semanticamente na interação das dimensões ${ }^{33}$ material, pragmática e sintática.

Igualmente, Bomfim (2014a) pondera que o campo de ação do design é o da configuração de objetos de uso. Para o autor, no processo de configuração, mais importante que o objeto em si é a interação objetivo-subjetiva entre produto e usuário, enfatizando que o processo de utilização é determinante para a constituição da figura (forma). A relação entre artefato e usuário é caracterizada pelo binômio função e necessidade. A cada conjunto de necessidades humanas poderia corresponder um objeto que agrupa funções, cuja natureza (prática, estética, simbólica) se refere a um tipo de satisfação desejada. Sobre essa plataforma, função seria a "qualidade de um objeto em atender necessidades, desejos e anseios do sujeito (indivíduo e sociedade)" (BOMFIM, 2014a, p.29).

Neste sentido, Löbach (2001) analisa as funções de um produto de design, separando-as em práticas, estéticas e simbólicas. O autor considera funções práticas todas as relações entre um produto e seus usuários que se situam no nível orgânicocorporal, ou seja, os aspectos fisiológicos de uso. Elas preenchem as condições

\footnotetext{
projetual", uma vez que poderia levar a interpretações equivocadas ou alheias ao seu estudo.

32 Para Lessa (2009), o conceito do artefato refere-se a uma síntese dos traços e características do artefato que mais fundamentalmente o determinam, sua essência de atuação no cotidiano humano. Lawson (2011) denomina o mesmo conceito como ideia central.

33 Dimensões abordadas por Niemeyer (2003).
} 
fundamentais para a sobrevivência do homem e mantêm a sua saúde física. Por outro lado, a função estética preenche as necessidades psíquicas no nível dos processos sensoriais, atuando por meio de elementos estéticos na aparência dos produtos. Por último, a função simbólica é determinada por todos os aspectos espirituais, psíquicos e sociais do uso, quando a espiritualidade do homem é estimulada pela percepção deste objeto, ao estabelecer ligações com suas experiências e sensações anteriores. Assim, tal função deriva dos aspectos estéticos (sensoriais) do produto, manifestando-se por meio de elementos como forma, cor, tratamento de superfície, os quais podem provocar a associação de ideias com outros âmbitos da vida, promovendo o encadeamento de estímulos subjetivos.

Bürdek (2006) reforça que, por meio da função formal-estética, se dão as vivências sensoriais dos elementos formais. Entretanto, para que um artefato adquira significado, precisa refletir seu uso (função prática ou indicativa) e se conectar ao contexto social (função simbólica). O autor usa os termos forma e conteúdo, e também sintaxe e semântica, para explicitar que a forma é portadora de signos e pode ser veículo para a produção de sentidos.

Contudo, Krippendorf (2000) adverte que os significados atribuídos pelo designer às formas projetadas não necessariamente serão percebidos igualmente pelos usuários, o que exige uma aproximação menos prescritiva e mais colaborativa por parte do designer. "O design é mais efetivo quando incrustrado na mesma comunidade que exige participação no futuro que ele realizará" (KRIPPENDORF, 2000, p.95).

A premência de grande aproximação com o universo usuário é vital, quando ponderada nas esferas do Design de Moda, pois o uso social dos artefatos de moda exige uma investigação empática do contexto destes sujeitos. Em contrapartida, os aspectos tecnológicos e mercadológicos constituem o outro polo fundamental de influências no projeto do vestuário de moda. Logo, para transpor os equacionamentos citados por Lessa (2009) ao domínio do Design de Moda, é essencial elencar as variáveis que emergem do contexto e originam os delimitadores projetuais da forma. 


\subsubsection{DELIMITADORES DA FORMA}

Na realidade industrial, o desenvolvimento de produtos de vestuário de moda se desenrola sobre uma trilha complexa e acelerada, em que o produtor nem sempre é quem comercializa e as decisões de produção dependem da intrincada e diversificada cadeia de fabricantes de fibras, de pigmentos, de tecidos e de aviamentos.

Perante este cenário, Treptow (2013), Jones (2005), Renfrew e Renfrew (2010), Sorger e Udale (2009) e Rech (2002) ressaltam o planejamento como etapa imprescindível para equacionar cronograma acelerado, processo criativo, sistemas produtivos e estratégias mercadológicas, já que esses fatores devem ser gerenciados, de forma antecipada e envolvem muitos profissionais. Esses autores se dedicaram a organizar e descrever as etapas do trajeto de desenvolvimento de produtos na área da moda. Os estudos citados apresentam diferenças na extensão de suas análises, a exemplo de Treptow (2013), que chega até a promoção e comercialização. Também não discutem exatamente o estudo de métodos projetuais do design, algumas explanações sobre design se concentram apenas em explicar os elementos e princípios sintáticos para explorar a composição estético-formal (denominados por Jones (2005) e Treptow (2013) como elementos e princípios de design), não estendendo ao conceito as acepções de processo ou gestão projetual. No entanto, por reunirem e organizarem os principais fatores atuantes no âmbito mercadológico e industrial do vestuário de moda, tais autores contribuíram nas sínteses sobre a delimitação projetual.

Treptow (2013), Jones (2005), Montemezzo (2003) e Rech (2002) concordam que as variáveis atuantes na delimitação dos objetivos projetuais congregam três principais grupos de informação: mercado (ciclos de moda e tendências de consumo), empresa (recursos disponíveis e posicionamento estratégico) e público-alvo (perfil corpóreo e estilo de vida).

$\mathrm{Na}$ mesma direção, Sanches (2011) resume as principais categorias de informação que direcionam o projeto de produtos de moda, mostrando a relevância da inserção do projeto no seu contexto gerador e destinatário, para a efetiva integração das demandas humanas, sistemas produtivos e gestão empresarial. A autora define o fluxo de informações (Figura 7) entre os universos de usuário e de corporativo, 
elencando as variáveis fundamentais para a delimitação projetual ${ }^{34}$ no Design de Moda e as vinculações com a síntese de diretrizes.

Figura 7 - Fluxo de informação e síntese na fase de preparação

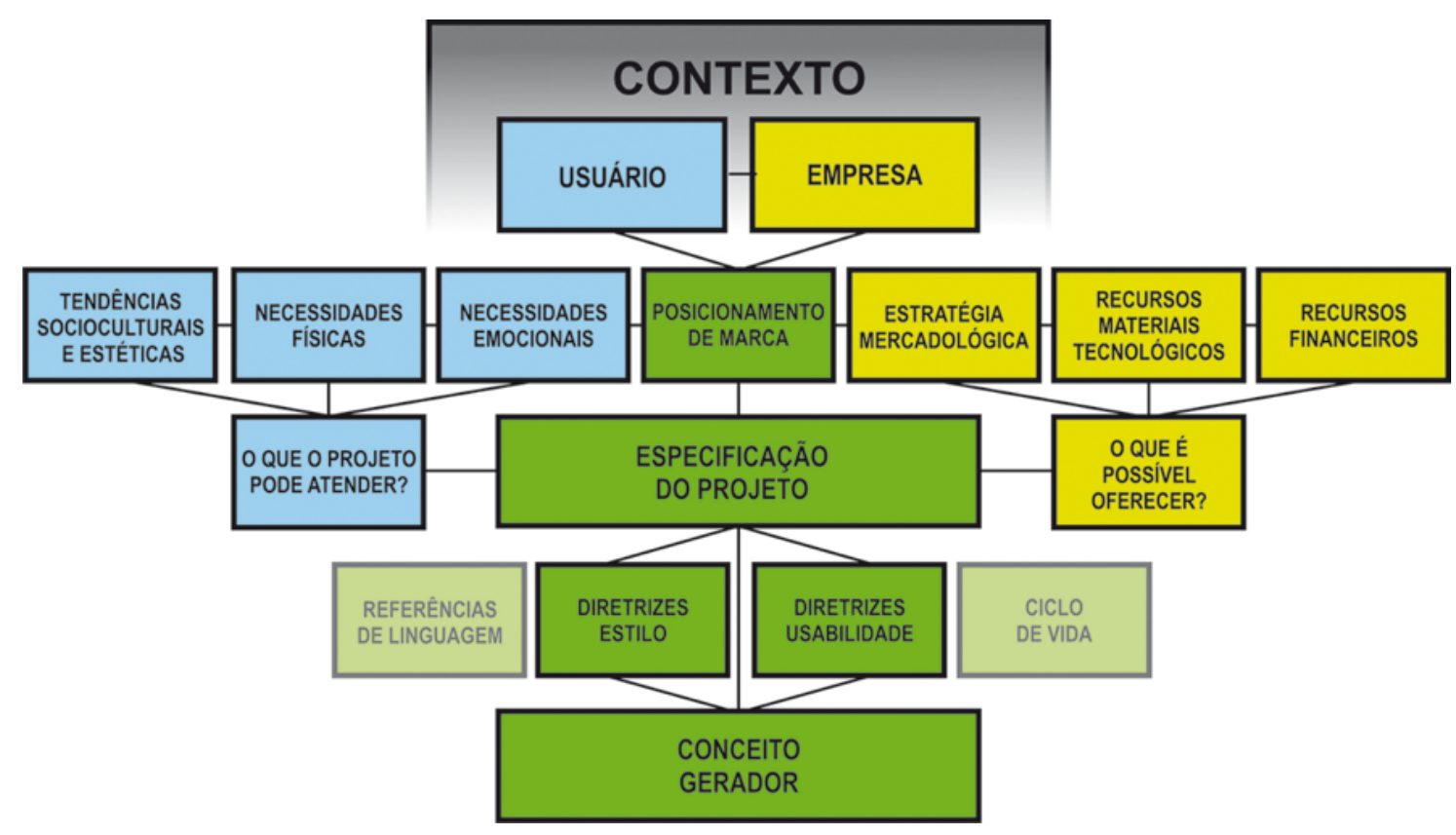

Fonte: Sanches (2011)

Sanches (2010; 2011), baseada nos estudos de Montemezzo (2003) e Löbach (2001), aponta quatro planos essenciais das ações projetuais, a saber:

A) Preparação: definir claramente o foco do projeto a partir da coleta de informações que esclareçam e delimitem o problema de design.

B) Geração: relacionar os parâmetros levantados criativamente entre si, gerando alternativas de solução.

C) Avaliação: selecionar as melhores alternativas, segundo os critérios de aceitação estabelecidos no início do processo.

D) Realização: desenvolver e concretizar a(s) alternativa(s) adequada(s).

Cabe observar que esta é a ordenação base utilizada no universo estudado. A autora examina estes quatro conjuntos de ações projetuais em paralelo aos estudos de

\footnotetext{
34 A autora também utiliza os termos preparação ou planejamento para denominar a fase de coleta e gestão de informação, quando são definidas as estratégias de projeto.
} 
Redig (2006) e, refinando as análises em Sanches (2011), delimita o foco projetual em cada um deles. Para situar a exposição, Redig (2006) distingue as principais categorias de ações que abarcam os procedimentos de um projeto de design, a saber:

A) Atender: refere-se a procedimentos para a exploração do contexto, promovendo a identificação de demandas e recursos disponíveis para delinear necessidades a serem satisfeitas.

B) Abranger: ressalta a conduta sistêmica do processo, enfatizando procedimentos que propiciem uma análise multifocal das conexões entre as variáveis e sujeitos envolvidos.

C) Inovar: enfatiza o pensamento criativo na busca por inovação na definição das funções do produto. Concentra-se na expressão e experimentação para evolução das propostas, em um movimento contínuo entre geração de ideias, análises e sínteses.

D) Depurar: destaca os ciclos de síntese e de avaliação para o refinamento e otimização da experiência de uso.

E) Sedimentar: enfoca procedimentos para a implementação do projeto, marcada por uma postura crítica, sob a qual se equacione os fatores de interação humana, de produção, de mercado e ético-sociais da melhor maneira possível.

Com base nos arcabouços precedentes, Sanches (2011) identificou os focos de cada plano essencial nas práticas projetuais do Design de Moda em ambiente acadêmico:

A) Preparar: aglutina atender e abranger, enfocando a contextualização e a síntese de diretrizes.

B) Gerar: perpassando por inovar e depurar, se concentra no movimento de experimentação de conexões entre os parâmetros sintetizados.

C) Avaliar: agregando depurar e sedimentar, focaliza a avaliação da eficácia destas interações e a evolução em ciclos de depuração.

D) Realizar: com acepção de sedimentação, enfoca a consolidação técnicoprodutiva, humana e social das propostas. 
Sanches (2011) exalta que esta organização não é uma cadeia linear de procedimentos, mas sim uma estrutura dinâmica que se entrelaça, se retroalimenta e absorve novas informações que a transformam. "Contudo, o ponto de partida é sempre o reconhecimento do cenário que envolve o usuário, das nuances deste contexto, para a identificação das suas necessidades e desejos." (SANCHES, 2011, p.2). Assim, a fase de preparação (delimitação projetual) parte da interpretação e decodificação do contexto para sintetizar as diretrizes do projeto e o conceito gerador.

Seguindo a mesma linha de raciocínio que embasa as definições de conceito do artefato (LESSA, 2009) ou ideia central (LAWSON, 2011), adotou-se o termo conceito gerador, à semelhança de Montemezzo (2003) e Sanches (2008), destacando que projetos de vestuário de moda, geralmente, englobam a concepção de vários artefatos em concomitância, vinculados por uma mesma ideia central. Essa essência partilhada guia os princípios funcionais/formal/visual do conjunto de artefatos projetados, respeitando a imagem da marca e as metas comerciais da empresa que propõe os novos produtos e/ou serviços. A diretriz expressa pelo conceito gerador é decodificada em elementos configurativos, guiando todo o processo projetual e ajudando a manutenção da coerência de linguagem.

Voltando ao diagrama de Sanches (2011), observa-se que ele se relaciona diretamente à fase de interesse desta pesquisa e à premissa de que a forma é a evidência do conceito do artefato (LESSA, 2009). Fica claro que os delimitadores para configurar o vestuário de moda são construídos em um sistema de relações em que estão incluídas, por uma parte, as possibilidades (ou restrições) oferecidas pelos materiais, pela tecnologia e pelo mercado e, por outra, a estrutura corpórea do usuário, bem como seus signos de representação social e de códigos específicos de expressão estética.

Dos argumentos supracitados se extraem dois princípios básicos para a delimitação da forma no Design de Moda: a) cada elemento configurativo é um enunciado visual e, concomitantemente, meio de adaptação física ao ambiente material; b) o enunciado visual da forma é altamente influenciado por conteúdos culturais. 


\subsubsection{FORMA E CONTEÚDO NO DESIGN DE MODA}

O valor de um artefato está intimamente ligado à avaliação subjetiva do seu desempenho na relação de uso. Um produto será considerado bom à medida que estabeleça algum sentido no cotidiano de seu usuário.

Para tanto, se presume que os enunciados visuais transmitidos por meio da sua configuração podem gerar percepções de natureza diversificada, evidências sobre a operacionalidade, o uso, as referências culturais, etc. Tais percepções, quando sobrepostas pelo usuário, em seu contexto sociocultural, são assimiladas e interpretadas, derivando decodificações que compõem o conteúdo simbólico do artefato. Assim, a ordenação configurativa é suporte da informação.

Como o principal objetivo desta pesquisa é ajudar os estudantes na delimitação de diretrizes expressivas para a sintaxe da forma, foram salientados os dois aspectos essenciais para o entendimento da configuração do vestuário de moda como enunciado visual, o tipo de informação que costuma influenciar o projeto (conteúdo expressivo) e o suporte visual (elementos configurativos).

\section{A) INFORMAÇÃO}

Para analisar a vestimenta como veículo comunicativo, retoma-se os componentes de uma mensagem visual não verbal: informação e suporte visual (MUNARI, 2006), sendo a informação o conteúdo a ser comunicado e o suporte visual a forma. Deste prisma, o conteúdo semântico do artefato se faz perceptível por meio do conjunto de elementos e relações compositivas que constituem sua forma. Porém, a definição de um referencial simbólico depende do estudo do contexto sociocultural, já que deve fazer parte do sistema de sinais sociais presentes no universo do usuário. Bomfim (2014) afirma, no mesmo rumo, que um objeto é constituído pela unidade entre figura (forma) e conteúdo. O conteúdo sintetiza o conjunto de fatores que definem a natureza objetiva e subjetiva do objeto, sua essência, e a forma expressa essa essência.

No entanto, como já citado, a comunicação depende de um processo de significação, compreendido nos intercâmbios entre aquilo que se embute na materialidade da forma e aquilo que pode ser extraído da experiência com o produto, a qual está sob a influência da percepção, do tempo, do espaço, da cultura e da memória 
do usuário (CARDOSO, 2012). Por consequência, o artefato é veículo expressivo, mas só se tonará mensagem (informação transmitida) no decorrer dessa interação com o usuário (BÜRDEK, 2006). Esse vínculo será estabelecido se o suporte formal/visual for coerente com os códigos expressivos que esse sujeito assimila, reforçando mais uma vez a premência da pesquisa das referências comunicativas inerentes ao universo do usuário. Nesta direção, certas categorias de informação são marcadas como indicadores para a delimitação de quesitos comunicativos no projeto de Design de Moda, conforme discutido a seguir.

Seivewright (2012) e Mbonu (2014) afirmam que, pela natureza cambiante da moda, o designer de moda precisa manter-se em uma atitude de investigação contínua para assimilar indicadores de configuração. Os autores frisam três enfoques para essa busca de informações: compilar e identificar potenciais referências (inspiração ${ }^{35}$ ) de linguagem; compreender as possibilidades dos recursos materiais (coletar e experimentar); conhecer o mercado alvo (universo consumidor/ imagem de marca/ concorrência). Certamente se percebe que as três abordagens se congregam na definição dos objetivos do projeto, aportando dados sobre conteúdos simbólicos, meios tangíveis de expressá-los e direcionadores para comercializá-los. Entretanto, também são percebidos dois polos de influência na delimitação de um conceito expressivo: um que se refere ao repertório e às interpretações pessoais do designer e outro relativo ao conjunto de diretivas prognósticas do mercado. No segundo polo emerge um tópico polêmico no Design de Moda, as tendências.

Antes de argumentar sobre isso, é importante assumir que conhecer os movimentos socioculturais é sempre relevante para quem projeta vestuário de moda. Estes movimentos geram padrões de comportamento, introduzindo e renovando códigos comunicativos na dinâmica social vigente, a qual está em sintonia direta com as significações construídas pela moda.

Este pressuposto conduz à concordância com Caldas (2004), para qual tendência consiste em uma manifestação, no âmbito do comportamento, do consumo ou do

\footnotetext{
${ }^{35}$ Termo usado na no âmbito da criação de moda para designar o elemento que funciona como estímulo mental para desencadear o processo criativo (MBONU, 2014). Ainda que haja interpretações distorcidas sobre o uso do vocábulo, muitas vezes atribuindo-lhe uma essência transcendental, que ocorre espontaneamente sem esforço, a literatura especializada sempre a vincula com uma pesquisa exaustiva. No ambiente acadêmico estudado o termo habitualmente usado é referência(s).
} 
"espírito do tempo ${ }^{36 ",}$, de uma sensibilidade anunciada por sinais. Contudo, alguns esclarecimentos são relevantes para justificar um posicionamento sobre o tema.

Segundo Erner (2010), o termo tendência serve para designar fenômenos muito variados, incluindo desde um movimento social de fundo, até as difusões rápidas de uma forma de expressão ou, ainda, um fenômeno comercial. Assim, é provável que a polêmica em torno das tendências já comece por aí. De outro ponto de vista, o mesmo autor analisa algumas teorias que marcaram historicamente o estudo de tendências, destacando dois enfoques principais: a) explicá-las a partir da leitura de fenômenos de moda, a partir da preferência por certos objetos, constituindo uma narrativa do espírito de uma época; b) estudar sua difusão, focando o processo de imitação e propagação de códigos culturais, enfatizando a difusão vertical dos gostos entre classes dominantes e dominadas. Estas linhas de pensamento também podem ter contribuído para alguns pré-conceitos sobre o tema, vinculando-o a interpretações sobre uma unificação massiva dos gostos ou acerca de uma manipulação do mercado.

Fiorini (2015) também resume alguns pré-conceitos, ou preconceitos, que permeiam as argumentações sobre tendência, os quais podem levar a um entendimento sobre as restrições em torno da aplicação no Design de Moda. A autora classifica os préconceitos sobre tendências nos seguintes eixos: a) são consideradas como fenômenos específicos de um campo, irrompendo como produtos novos, inesperados, em termos de design e consumo. Os produtos, nas esferas de uma tendência, muitas vezes, são apresentados como representantes de uma ruptura com o passado, novas imagens e estéticas a serem consumidas; b) são decodificadas unicamente por especialistas ou consultores, os quais suprem as marcas de um glossário de formas, cores e texturas que serão adotadas pela indústria e pelo mercado de maneira massiva. No outro extremo, supõe-se que as tendências são as expressões espontâneas que se formam nas ruas, a partir dos estilos propostos pelos próprios usuários, apontando modelos estéticos capazes de influenciar os designers e as marcas; c) provêm apenas dos centros tradicionais, como Paris, Milão, Londres, Nova York, etc. Consequentemente, os locais não situados entre estes centros tradicionais estariam sempre defasados (uma

\footnotetext{
${ }^{36}$ Originado do conceito alemão Zeitgeist, se refere à direção geral que tomam o gosto e a sensibilidade, marcando definitivamente uma época (CALDAS; 2004, p.213).
} 
temporada atrás) na absorção de novos códigos de consumo; d) são pensadas, em sua essência, como modas passageiras e frívolas, mudando apenas a aparência superficial dos produtos, mas não suas qualidades técnicas, formais ou simbólicas.

Essa argumentação expõe pontos frequentes nas explanações sobre o assunto, os quais podem levar a interpretações reducionistas como, por exemplo, que tendência é algo pontual, superficial, isolado de sua trama de raízes socioculturais ou, ainda, que as tendências são propagadas e absorvidas por uma via de mão única, sem qualquer influência transformadora do entorno cultural que a assimila ou do designer que a interpreta.

Seguramente, a complexidade do tema se liga à dificuldade de decifrar a simbologia do tempo presente em escala coletiva, ou ao risco da arbitrariedade, quando se relacionam causas sociais à preferência coletiva por certos objetos-símbolos. Entretanto, um ponto se comprova nos argumentos anteriores, as tendências nascem da conjunção de influências socioculturais e, quando um indivíduo as adota, articula as necessidades de se particularizar e de pertencer, como corrobora Caldas (2004). Por conseguinte, conclui-se que é importante estudar as influências que permeiam o jogo de identificação e distinção, considerando que as soluções projetadas serão meios expressivos nesse jogo.

Treptow (2013) explica que o conteúdo de moda (tendências) assimilado por muitas empresas advém de estudos dos comitês setoriais da indústria, agências especializadas em prospecção psicossocial e monitoramento de mudanças nos comportamentos de consumo. Porém, observa-se que estas previsões são disponibilizadas por entidades que costumam decodificar estes estudos, em indicadores estético-visuais para a moda, chegando, em muitos casos, a oferecer informação pasteurizada, como a sugestão de detalhes concretos para a configuração dos produtos.

Perante essa realidade, no que concerne à utilização dos estudos prognósticos como fonte de pesquisa projetual, Caldas (2004) recomenda prudência. Essas fontes podem ser, entre muitas outras, sinalizadores de linguagens estéticas vigentes, porém, consultá-las significa, sobretudo, tomar ciência dos indicadores de disponibilidade dos materiais, para o planejamento produtivo da empresa diante da obsolescência programada. Isso indica, em termos de projeto de produtos, que em um certo período, 
poderá haver maior disponibilidade de determinadas qualidades visuais (cor, textura, padronagem).

Em relação ao papel dessas informações na delimitação projetual, no âmbito educacional do Design de Moda, observa-se o mesmo posicionamento cuidadoso. Admite-se que a investigação de tendências comportamentais, e seus indicadores de valores e estilos de vida, é um dos meios de identificar códigos comunicativos compartilhados no tempo presente e no mercado. Não obstante, é preciso estimular a experimentação de novos pontos de vista e o desenvolvimento de meios inovadores de soluções. Por isso, quando utilizados, tais indicadores devem se inserir de modo seletivo, passando pelo filtro interpretativo do designer (ou estudante), balizado no estudo minucioso do universo do usuário. O contato com os prognósticos do mercado será produtivo na medida em que auxilie a habilidade de decodificar conteúdos de moda para observar aspectos de consumo simbólico.

Neste sentido, Fiorini (2015) propõe que as tendências sejam aplicadas ao campo do Design de Moda como um canal de tramas abertas, dando entrada aos fenômenos de inovação e de interpretação de signos detectados pelo designer no transcurso projetual. Longe de serem estáticas e propor uniformidade, se articulam com o olhar e a narrativa de design que possui a marca, o designer ou o estudante de design.

Concordando com Fiorini (2015), a ideia de fórmulas prontas, em um ambiente de formação do raciocínio projetual, é completamente incoerente. Deste modo, o repertório interpretativo do projetista, citado no início deste tópico, será de extremo valor para a definição do conteúdo (informação) expresso pela forma (suporte visual) do produto. A exploração de novas perspectivas e a habilidade de combinar criativamente as referências pesquisadas, propondo meios singulares de expressar conteúdos simbólicos, promoverá o exercício da identidade de linguagem.

Assim, a definição de conteúdos expressivos para articular o enunciado visual será extraída de conteúdos referenciais entrelaçados, nos quais estão presentes a informação de moda (tendência), a identidade estilística ${ }^{37}$ de marca e,

\footnotetext{
37 [...] o designer deve buscar o equilíbrio entre os dois componentes fundamentais do sistema de oferta na moda, aquele de natureza permanente - posicionamento de mercado, conceito de marca - e o sazonal, que garante ao consumidor uma contínua evolução das propostas, sem colocar em risco os componentes permanentes, definindo a modalidade de renovação dos códigos estilísticos da empresa, sempre respeitando a identidade estilística permanente. (SAVIOLO \& TESTA, 2000, apud PIRES, 2004, p.16).
} 
indiscutivelmente, os signos subjacentes ao estilo de vida e valores do usuário (cotidiano e ideologias). Por isso, a investigação de conteúdos simbólicos para a configuração da vestimenta não pode ser reduzida à ideia de compilar dados estéticos/visuais para inspirar uma expressão autoral ou uma reinterpretação de informação pronta.

Fiorini (2015) confirma que o âmago do processo projetual no Design de Moda é articular a relação forma-conteúdo, para concretizar, por meio da forma projetada, um canal de comunicação. Por conseguinte, é fundamental que a formação propicie, em primeiro lugar, a investigação criativa para associar fontes de informação e sintetizar códigos de linguagem, em segundo lugar, o conhecimento dos elementos que articulam essa linguagem, ou seja, os fundamentos que podem ajudar a sintaxe da composição formal/visual. Em vista disto, destacam-se pontos essenciais para a ordenação do suporte visual dos conteúdos supracitados.

\section{B) SUPORTE VISUAL}

Dondis (1997) alerta que o manejo da linguagem visual requer um conhecimento de como se organizam as estruturas formais, conceituais e relacionais em uma composição visual. O modo visual constitui um corpo de dados que pode ser empregado para compor e compreender mensagens em diversos níveis de utilidade. Tal composto se constrói por unidades agrupadas que, em uma rede de influências mútuas, propiciam significações.

Lessa (2009), referindo-se ao campo específico do design, constata que, historicamente, o aprendizado de fundamentos formais/visuais foi uma preocupação constante nas investigações pedagógicas para o ensino de design. Muitos estudos foram efetuados no campo da linguagem visual ou linguagem formal e, ainda que tenham tomado abordagens muito diversificadas, se identificam com um propósito essencial: "de fornecer referências para o projeto, tendo em vista categorias, relações e elementos básicos da forma e da visualidade" (LESSA, 2009, p.71). O autor opta por qualificar duplamente o termo linguagem e utiliza linguagem formal/visual, explicando a forma 
como evento sensorial/perceptivo, receoso de que o vocábulo possa ser compreendido apenas em termos de modelização ou abstraído de conteúdo (forma pura).

Convém realçar que esta investigação não pretende discutir a apropriação dos termos sintaxe e linguagem no âmbito não verbal, apenas grifa que o uso do termo sintaxe se refere à caracterização de unidades compositivas do conjunto formal e seus princípios de interação, mas resguarda o pressuposto de que, apesar da apropriação, a natureza da linguagem visual é muito distinta da verbal. Sob essa ressalva, previne-se que a gama de possibilidades sintáticas é menos prescritiva, a distribuição dos elementos não é linear e as relações perceptivas são simultâneas. Tampouco se ambiciona esmiuçar o conteúdo sobre os elementos da "gramática" visual. O propósito de abordar alguns fundamentos de linguagem visual é puramente didático, analíticodemonstrativo. Almeja-se apenas explicitar referências que demonstrem o conceito de sintaxe na composição plástica do vestuário moda.

Compor, no âmbito da linguagem formal/visual, é manejar quesitos objetivos e subjetivos (LESSA, 2009). A distribuição e integração dos componentes formais/visuais são influenciadas pelo partido comunicacional escolhido e, também, pelos fatores de operacionalidade. Neste rumo, pode-se inferir que a configuração da vestimenta, como canal expressivo, pode facilitar a experiência de uso e dar pistas simbólicas reconhecíveis do contexto do usuário (códigos estético-culturais).

No entanto, por sua natureza não verbal, como já elucidado por Cardoso (2012), o artefato promove significações variantes e interpretações particulares que entram no fluxo da expressão individual do usuário. Este encadeamento ajuda a entender a ampliação sintática que adquire o vestuário de moda no processo de uso. Quando o usuário associa uma peça de vestuário a outras ${ }^{38}$, construindo combinações particulares, este produto se torna elemento configurativo na sintaxe de uma multiplicidade de composições formal/visuais mais amplas, as quais transitam em tempos e ambientes distintos.

De outra perspectiva, a ideia de combinatórias sintáticas entre artefatos é fundamental para elucidar uma característica importante do projeto de produtos de vestuário moda: a coleção. Fiorini $(2008$, p. 108) explica que uma coleção consiste em

\footnotetext{
${ }^{38}$ Essa associação remete à reflexão sobre sintagmas e paradigmas abordada anteriormente.
} 
"duas ou mais séries de produtos que possuem elementos de ordem conceitual comum, funcional, morfológica e técnica".

Ao considerar as relações funcionais e comunicacionais que fomentam a interdependência do conjunto, Fiorini (2008) aborda a coleção como um sistema em que os elementos (produtos) compartilham uma essência comunicativa que se repete, se desenvolve e se transforma. Neste transcurso se desenvolve uma narrativa de mensagens complementares, um relato de:

alternativas formais e opções funcionais para o usuário, utilizando sua capacidade associativa e combinatória: desde o produto mais básico ao mais experimental, todos compartilham um discurso comum, emitem a mesma mensagem. Nós nos encontramos diante de sistemas estruturados por constantes (comunicacionais) e variáveis (materiais, formas e usos) que reforçam a mensagem de maneira diversificada, sem se converterem em uma transformação monótona, previsível (FIORINI, 2008, p.110).

Expandindo ainda mais essa noção de sintaxe ampliada, é relevante citar que o vestuário de moda é oferecido ao usuário por meio de um fluxo comunicativo maior: o conjunto de elementos que constrói a atmosfera da imagem de marca. Material publicitário, vitrines, ambiente de venda, odores, embalagens, abordagens de atendimento, etc., compartilham um código, articulam uma linguagem, enfim, ao planejar a forma, é preciso estar ciente dos elementos sintáticos que já fazem parte desse universo.

Segundo Souza (2008), no caso do vestuário, a informação é percebida em um ângulo de $360^{\circ}$, envolvendo uma sensorialização externa e interna e, ainda, sob o efeito da mutabilidade da forma, conforme o movimento do corpo e da matéria têxtil. Este dinamismo exige que a composição seja planejada em interação com a estrutura corpórea, o comportamento dos materiais e os recursos construtivos para gerar a forma tridimensional. Assim, se torna indispensável que as estratégias para configurar visualmente o vestuário levem em conta a tridimensionalidade dinâmica do plano expressivo, a sintaxe ampliada e a dependência da estrutura corporal como sustentação física e visual.

Pelo exposto, é possível realçar três tipos de conhecimentos indispensáveis à instrumentalização do estudante para compor o suporte formal/visual: a) recursos materiais - relativos, principalmente, à matéria têxtil, já que esta oferece a superfície 
(plano) que traz cor e textura para a composição; b) recursos construtivos - relativos à modelagem e à tecnologia da confecção, possibilitam a conversão da superfície em uma composição tridimensional vinculada ao corpo (silhueta). Oferecem uma infinidade de possibilidades para conceber as unidades configurativas e conectá-las na estrutura compositiva; c) fundamentos sintáticos - auxiliam o planejamento da integração dos elementos configurativos, auxiliando a percepção da informação estético-simbólica.

Os recursos materiais têm propriedades intrínsecas que devem ser consideradas na linguagem do produto, pois atuam diretamente na percepção do artefato. As características físicas, derivadas da composição (fibras) e da construção têxtil, como densidade, elasticidade, resiliência ou caimento, estão diretamente implicados na estruturação da silhueta e, consequentemente, na informação de ocupação espacial. De igual modo, as propriedades óticas da superfície, como cor, textura (também tátil) e opacidade podem caracterizar de imediato um indicativo simbólico, a exemplo de um tecido rosa claro aveludado, que poderia ser interpretado sob as convenções que atrelam tais características à inocência e à feminilidade.

Quanto aos recursos construtivos que materializam a forma, Souza e Menezes (2011, p.83-84) definem que:

\footnotetext{
Babados, nervuras, drapeados, franzidos, recortes, entre outros, dependendo de como são projetados, constituem-se importantes elementos de construção. O próprio material têxtil pode contemplar a estrutura pretendida, seja por suas características específicas de peso e caimento ou por intervenções aplicadas em sua superfície, neste caso, tornando-o autoportante. Para Souza e Menezes (2010), estes elementos que permitem estruturar a forma do produto - utilizados de modo isolado ou combinados entre si - podem ser denominados de recursos construtivos, na medida em que promovem sustentação e ajustamento ou configuram volumes que garantem o equilíbrio requerido.
}

O conhecimento dos recursos materiais e construtivos, no entanto, precisa ser agregado aos princípios da sintaxe visual, para que a forma construída seja também forma expressiva. Assim, o conhecimento dos fundamentos sintáticos completa o instrumental para articular a configuração. Todavia, Wong (1998) adverte que a impossibilidade de preceitos rígidos para uma "gramática" visual promove uma diversidade de interpretações, ou classificações distintas, entre os autores que abordam este tema. Por isso, foram tomados como base os estudos de Gomes (2003), de Lupton 
e Phillips (2008), de Leborg (2006), de Wong (1998) e de Dondis (1997) para explicar os elementos da sintaxe visual, porém a organização do conteúdo foi definida de acordo com a experiência da presente pesquisadora e as necessidades de aplicação na pesquisa. Independentemente das escolhas de classificação e organização dos conteúdos, os autores citados concordam na identificação das unidades básicas que, coordenadas, compõem a forma: ponto, linha, plano e volume. Estes elementos se associam no espaço compositivo (bi ou tridimensional) e, sob a influência das forças que regem a percepção humana, constituem o objeto comunicativo. Igualmente, se introduz o assunto conceituando tais elementos, sob o prisma de relações (Quadro 4).

Quadro 4 - Resumo dos conceitos sobre as unidades visuais

\begin{tabular}{|c|c|c|c|c|}
\hline & PONTO & LINHA & PLANO & VOLUME \\
\hline 崖 & $\begin{array}{l}\text { Unidade mais simples } \\
\text { e irredutível. } \\
\text { Não ocupa nenhuma } \\
\text { área ou espaço, não } \\
\text { tem dimensão. }\end{array}$ & $\begin{array}{l}\text { Sucessão de pontos } \\
\text { adjacentes promove a } \\
\text { sensação de direção, } \\
\text { derivando a linha; ou o } \\
\text { registro da trajetória de um } \\
\text { ponto em movimento define } \\
\text { uma linha. } \\
\text { Unidimensional: } \\
\text { comprimento }\end{array}$ & $\begin{array}{l}\text { Sucessão de linhas } \\
\text { adjacentes ou o } \\
\text { registro da trajetória } \\
\text { de uma linha em } \\
\text { movimento (em } \\
\text { direção distinta à sua } \\
\text { direção intrínseca) } \\
\text { define um plano. } \\
\text { Bidimensional: } \\
\text { comprimento e } \\
\text { largura }\end{array}$ & $\begin{array}{l}\text { Sucessão de planos } \\
\text { adjacentes ou o } \\
\text { registro da trajetória de } \\
\text { um plano em } \\
\text { movimento (em } \\
\text { direção perpendicular) } \\
\text { define um volume. } \\
\text { Porção espacial } \\
\text { limitada por planos. } \\
\text { Tridimensional: } \\
\text { comprimento, largura } \\
\text { e profundidade. }\end{array}$ \\
\hline 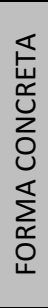 & $\begin{array}{l}\text { Indica uma posição no } \\
\text { espaço compositivo. } \\
\text { Centro de atração } \\
\text { visual. }\end{array}$ & $\begin{array}{l}\text { Estabelece direção visual } \\
\text { (horizontal/vertical/diagonal). } \\
\text { Contorna, delimita } \\
\text { superfícies (área). } \\
\text { Poder de expressão e } \\
\text { estruturação compositiva. }\end{array}$ & $\begin{array}{l}\text { Tem espessura } \\
\text { mínima em relação } \\
\text { ao comprimento e } \\
\text { largura - Superfície. } \\
\text { Delimitado pela } \\
\text { sensação de área } \\
\text { contornada - Forma } \\
\text { plana. }\end{array}$ & $\begin{array}{l}\text { Sólido ou oco (abarca } \\
\text { espaço e superfícies). }\end{array}$ \\
\hline
\end{tabular}

Fonte: elaborado pela autora com base em Lupton e Phillips (2008), Leborg (2006), Wong (1998) e Dondis (1997).

De acordo com Wong (1998), os elementos conceituais não são visíveis, ou seja, quando um ponto redondo é representado em uma folha de papel, mesmo que pequeno, ele passa a ter um formato com a cor e a textura do grafite. Em realidade, se converte em uma forma bidimensional. A percepção do seu tamanho muito pequeno 
em relação à folha é que o coloca na condição de ser denominado como ponto, tornando secundária sua medida de raio ou a área que ocupa. Do mesmo modo, a linha também passa a ter largura, quando materializada, e um plano passa a ter espessura, mesmo que ínfima. Por isso, ao mencionar uma linha ou um ponto na configuração da mensagem, ainda que o foco seja analisar o seu papel na composição visual, também se trata de uma forma concreta (uma unidade de forma), concomitantemente, unidade de expressão e de construção.

Retomando estas unidades básicas como elementos de expressão no vestuário de moda, observa-se que as possibilidades de combinação são infindáveis, ou seja, a superfície têxtil se torna um plano em movimento sobre a estrutura do corpo, abarca espaços e define volumes. Souza (2006) ratifica esse pensamento, quando usa o mesmo raciocínio de evolução entre ponto, linha, plano e volume para explicar os fundamentos aplicados à modelagem do vestuário. A partir destas unidades de forma, a autora explica que o volume da vestimenta é configurado pela união de planos têxteis.

Deste modo, uma forma pode transmitir peso ou leveza, uma série de botões direciona o olhar e se converte em uma linha que pode marcar simetria e estabilidade, um elemento de cor diferente na padronagem do tecido se coloca como uma quebra de regularidade, mostrando-se como um ponto que atrai o olhar e promove tensão visual.

Contudo, sensações como atração, direção, ou tensão visual imputadas às unidades formais são caracterizadas pelo funcionamento da percepção humana. Para decifrar a percepção da forma, os estudos da Gestalt ${ }^{39}$ sobre as forças atuantes no processo perceptivo ajudam a entender como os elementos constitutivos podem se agregar ou se opor visualmente, definindo relações de vínculo, contraste, pregnância e hierarquia no conjunto expressivo.

Sobre estes aspectos, Gomes (2003) destaca as forças internas de organização que estruturam a percepção da forma visual: a) unificação e segregação - agem de acordo com a igualdade ou desigualdade (contraste) do estímulo visual, propiciando a capacidade perceptiva de separar, identificar ou evidenciar unidades formais em uma composição ou em partes dela; b) fechamento e continuidade - a percepção dirige-se

\footnotetext{
39 Gestalt: escola de psicologia experimental alemã que, com seus estudos sobre a percepção, linguagem, inteligência, aprendizagem, memória, motivação e conduta social, aportou contribuições relevantes no campo da teoria da forma (GOMES, 2003).
} 
a uma ordem espacial que pende à formação de unidades em todos fechados. O cérebro tende a produzir linhas imaginárias para completar ou continuar a impressão de uma estrutura lógica interrompida. A "boa continuidade" representa a sensação de não interrupção da organização visual, uma sequência de estímulos em harmonia e fluidez; c) proximidade e semelhança - elementos próximos costumam ser percebidos em grupos. Do mesmo modo, unidades formais semelhantes tendem a se vincular visualmente e formarem conjuntos.

Essas forças agem em concomitância e conhecê-las pode auxiliar a decidir como vincular as unidades compositivas. Para evidenciar a integração dos elementos configurativos e as relações, a Figura 8 apresenta um exemplo em vestuário de moda.

Figura 8 - Exemplo do conjunto das relações de sintaxe visual

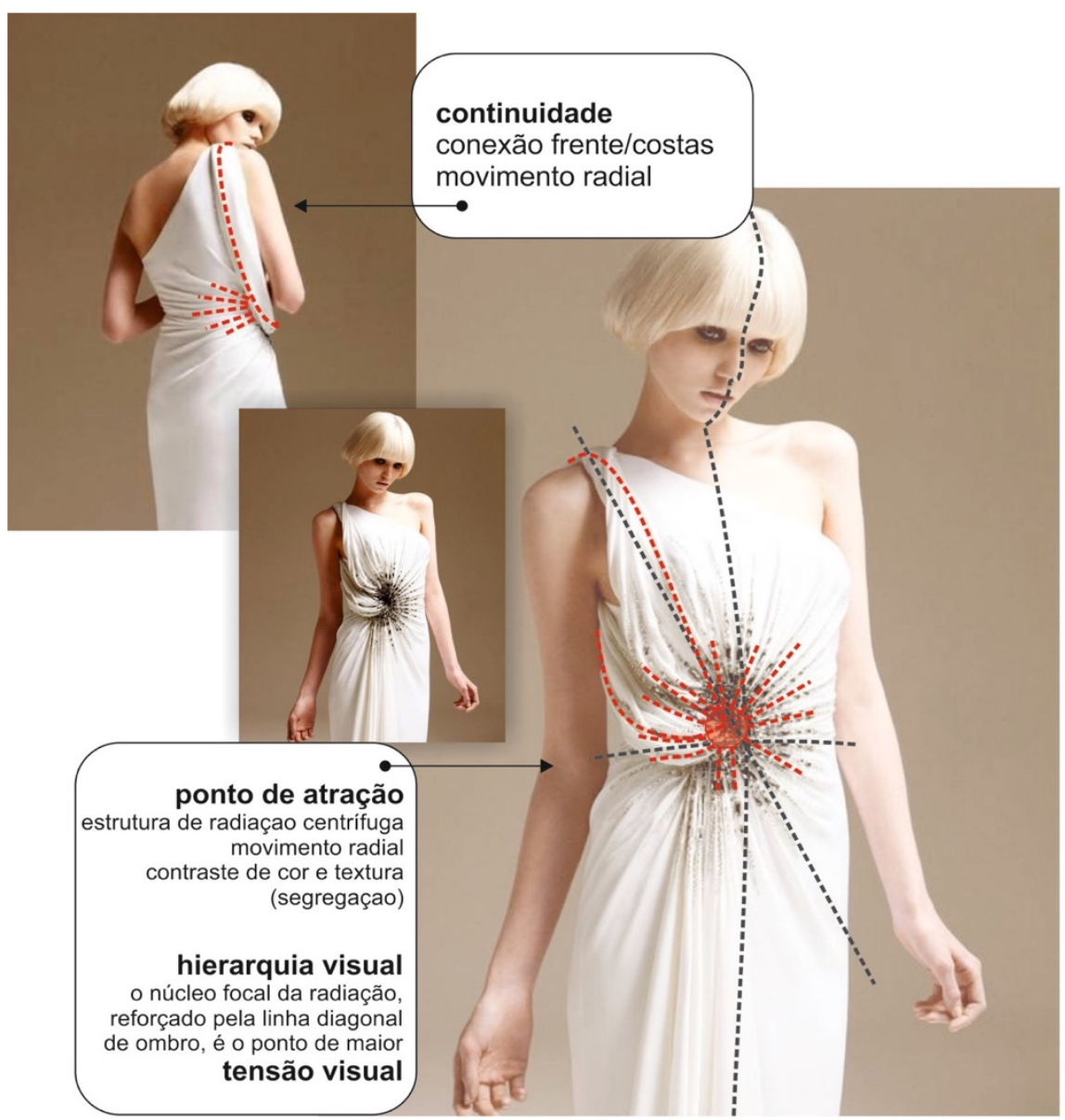

Fonte: elaborado pela autora - fotos de WEDDING DRESSES STYLE (2012)

No exemplo anterior, as relações grifadas explicitam a articulação de oposições (segregação/contrastes) e agregações (continuidades) para atribuir destaque e dirigir o 
olhar a uma área da superfície da silhueta, criando uma hierarquia entre as unidades configurativas. Esse exemplo ilustra o cerne da sintaxe visual, que consiste, segundo os autores de referência já mencionados, em criar coesão entre as unidades de forma e dirigir a ênfase da percepção.

Ponderando os argumentos elencados, ainda que a tridimensionalidade dinâmica do vestuário ofereça múltiplos pontos de vista, examinar quais elementos devem promover maior impacto visual é um bom princípio. Isso incide diretamente sobre a recepção da informação visual, derivando o nível de pregnância $^{40}$ da composição. Assim, o enunciado visual não se perderá na fragmentação de estímulos.

Para resumir, a Figura 9 ilustra o arcabouço subjacente à mensagem visual dinamizada pelo vestuário de moda, mostrando que a expressão dos conteúdos, intermediados pelos componentes materiais da forma, depende de uma estratégia de sintaxe. Em outras palavras, para articular conteúdos simbólicos, é imperativo saber como manipular as combinatórias dos elementos visuais presentes nos suportes materiais (corpo/matéria têxtil/aviamentos ou acessórios), fazendo dele suporte visual da informação.

Figura 9 - Anatomia da mensagem visual no vestuário de moda

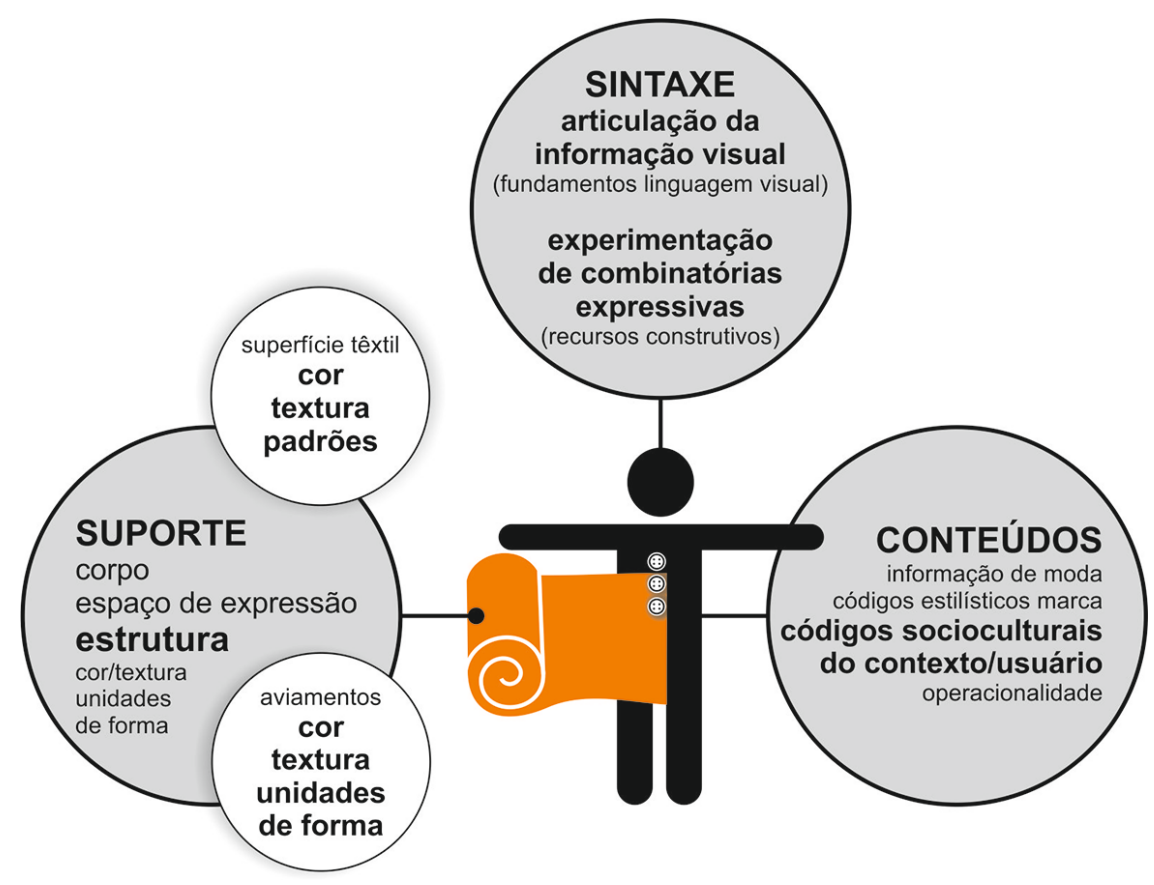

Fonte: acervo da autora (2012)

\footnotetext{
40 "Quanto melhor for a organização visual da forma do objeto, em termos de facilidade de compreensão e rapidez de leitura ou interpretação, maior será o seu grau de pregnância" (GOMES, 2003, p.37).
} 
Por fim, confirma-se que as diretrizes que orientam a sintaxe formal do vestuário de moda advêm de uma delimitação projetual unificada, por meio da qual se define o sistema de relações que afetam a configuração, incluindo as possibilidades (ou restrições) oferecidas pelos materiais, pela tecnologia e pelo mercado, a estrutura corpórea do usuário, bem como seus signos de representação social e códigos específicos de expressão estética.

Tendo em vista as indagações que originaram esta pesquisa, discutir a delimitação projetual era indispensável para cumprir seus objetivos. As análises promoveram a identificação dos delimitadores necessários para gerar conceitos expressivos, mas também realçaram a premência de um tratamento integrante e holístico na gestão das informações de projeto. Esse indicador se confirmou nas ações diagnósticas do trajeto investigativo, pelo que se direcionou a busca por bases teóricas que apoiavam as características sistêmicas da gestão do processo projetual. 


\section{CAPÍTULO 3}

-

Conexões teóricas sobre o pensamento e a educação projetual 


\section{CONEXÕES PARA O ENSINO/APRENDIZAGEM DE PROJETO}

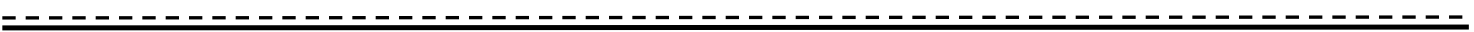

O capítulo três trata das conexões teóricas que orientaram o posicionamento para as ações em campo, permitindo que o leitor acompanhe o caminho que levou à construção das ferramentas introduzidas nas práticas em sala de aula. O principal fim é argumentar sobre o enfoque sistêmico, agregando os fundamentos relativos ao processo de design ao raciocínio de delimitação projetual descrito no capítulo anterior. Não se trata de classificar tal percurso entre os diversos modelos que descrevem o projeto de design, mas de destacar as ações de pensamento ali envolvidas e situar o uso de ferramentas para a sintaxe formal/visual neste raciocínio. Por esta razão, abdicou-se de relatos históricos sobre a evolução das metodologias do design e da comparação pormenorizada entre modelos específicos. Os esforços foram aplicados em resumir as bases que sustentaram o vínculo entre o pensamento projetual e as estratégias metodológicas para a delimitação projetual.

É crucial recordar que, no contexto estudado, três condições já eram preexistentes: a interdisciplinaridade, a valorização das ferramentas imagéticas e o incentivo à pesquisa científica. Tais fatores direcionaram a busca por teorias que contemplassem estratégias holísticas, integrantes, e que aproveitassem as premissas de pensamento visual e pesquisa.

\subsection{PROJETAR NO CENÁRIO COMPLEXO}

-

O estudo do cenário atual é essencial para a delimitação da abordagem desta reflexão, não apenas para aclarar conceitos, mas também para evidenciar os níveis de interação que tal cenário estabelece com o objeto de estudo, visto que investigar moda encerra um compromisso implícito de contextualização do momento presente. Neste sentido, a seguir destacam-se alguns pontos essenciais à compreensão da contemporaneidade ${ }^{41}$, evidenciando os fatores que agem sobre o Design de Moda.

\footnotetext{
${ }^{41}$ Cabe explicitar que o termo contemporâneo se reporta ao período histórico presente, à atualidade, e
} não tem a pretensão de representar nenhum preceito de pensamento ou cânone de linguagem estética. 
As transformações socioculturais da globalização criaram um mundo intricado, marcado por uma realidade multifacetada, híbrida e em contínuo movimento. Moraes (2008) retrata um contexto marcado pela diversificação das demandas, a comunicabilidade instantânea, os signos transitórios e as realidades simultâneas. Esse fenômeno é denominado como complexidade. Projetar no cenário complexo tem sido um tema recorrente entre os estudiosos do design (VASSÃO, 2010; MORAES, 2008, 2010; BÜRDEK, 2006; CARDOSO, 2012; VAN DER LINDEN; LACERDA, 2012). No contexto múltiplo e veloz, projetar produtos e/ou serviços é uma tarefa igualmente complexa, visto que as demandas não são instantaneamente identificadas e os valores imateriais se mostram, cada vez mais, relevantes nas motivações do consumo, principalmente quando se discute o desenvolvimento de produtos dotados de conteúdo de moda, nos quais a subjetividade e a renovação são premissas básicas.

Para captar melhor esse panorama buscaram-se, em um breve olhar sobre este período de mutações, alguns pensadores que analisam o desenrolar histórico da cultura moderna e pós-moderna ${ }^{42}$. Giddens (1991) denomina o período como modernidade tardia, caracterizando-o não como ruptura histórica da modernidade para a "pósmodernidade", mas como um movimento transformador no qual as características da modernidade se aguçam ou parecem se reorganizar completamente, metabolizando novas formas de viver.

Para esclarecimento, Giddens (1991) define como modernidade a transformação social iniciada na Europa por volta do século XVII. A vida coletiva se estruturava sobre um projeto racional e linear de ordem, alavancado pelo capitalismo, a industrialização e as relações de poder, impulsionando a evolução industrial e tecnológica. A solidez almejada pelo progresso tecno-científico se guiava pelo princípio de conhecer para controlar (a natureza), buscando uma existência social estável, a qual levaria todos os indivíduos desta sociedade a uma vida melhor.

A modernidade proporcionou a possibilidade de deslocamentos espaciais cada vez maiores em tempos cada vez mais reduzidos, criando um descolamento entre

42 Ressalta-se que o interesse era pontuar aspectos essenciais da contemporaneidade, independentemente da denominação que cada autor lhe atribui. Logo, os termos pós-modernidade, modernidade líquida, hipermodernidade, modernidade tardia foram usados de acordo com o autor citado, uma vez que a intenção era apenas perceber a contextura atual, que aloja as manifestações da moda. 
tempo e espaço, o qual resultou em um fenômeno de descontextualização, que Giddens (1991) chamou de desencaixe. Outro conceito, denominado reflexividade (GIDDENS, 1991) é, aparentemente, uma das características da modernidade que mais se acentua na modernidade tardia. A reflexividade consiste na avaliação constante das práticas sociais, as quais são continuamente examinadas e alteradas, a partir de informação renovada sobre estas próprias práticas. Tal fenômeno, assim como o desencaixe, se acelerou, abalando a utopia da estabilidade e transformando o mundo moderno.

Para Bauman (2001), a solidez do mundo moderno ${ }^{43}$ deu lugar à fluidez, a qual se distingue por não se ater a uma forma fixa e estar constantemente propensa a mudála. A partir desta metáfora o autor explica a natureza da fase atual, batizando-a como modernidade líquida, definida pela mobilidade e a inconstância. $\mathrm{O}$ autor discorre sobre esta liquidez que invadiu os setores estáveis da modernidade, apontando como principais particularidades a desterritorialização da economia, a flexibilidade do trabalho, os deslocamentos das relações de poder e a diversidade de possibilidades individuais para as atuações sociais.

Lipovetsky (1989) também enfatiza esta infinita gama de possibilidades de escolha que se coloca à disposição dos indivíduos do referido período. Examinando a sociedade de consumo, destaca a construção do sujeito autônomo, do consumidor protagonista em um entorno eclético, múltiplo e efêmero.

Os aspectos aqui enfatizados levam ao questionamento sobre os sujeitos que vivenciam a sociedade atual e, mais especificamente, sobre as identidades que se constroem neste meio instável. Tendo em vista que o vestuário de moda permeia, inevitavelmente, um processo de identificação e personalização, surge a pergunta: como seria o indivíduo neste cenário?

Na tentativa de desvendar este sujeito, resgata-se Hall (1998), que identifica três concepções de identidade por meio da evolução histórica da individualidade, a saber: o sujeito do lluminismo, o sujeito sociológico e o sujeito pós-moderno.

Nesta ordem, o primeiro seria o ser humano autônomo, único, centrado, unificado e coerente. Já o segundo teria sua identidade edificada por meio do diálogo

\footnotetext{
43 O projeto moderno é marcado pela constante luta contra a ambivalência, uma busca incessante de formas de conhecer, classificar e ordenar o mundo.
} 
incessante com as pessoas da sociedade em que vive, refletindo a crescente complexidade do mundo moderno, em que o núcleo interior do sujeito não é autônomo e autossuficiente, isto é, o eu interior seria formado, e transformado, de acordo com as experiências no mundo cultural exterior. "A identidade, então, costura [...] o sujeito à estrutura. Estabiliza tanto os sujeitos quanto os mundos culturais que eles habitam, tornando ambos reciprocamente unificados e predizíveis." (HALL, 1998, p.12)

Em relação ao último, mais relevante para este estudo, o autor enfatiza que o indivíduo da pós-modernidade é marcado pela fragmentação, compondo-se, não de uma, mas de várias identidades, conforme os contínuos deslocamentos de tempo e espaço, os quais o colocam em contato com sistemas de significação e representação cultural que se multiplicam, confrontando uma série de identidades possíveis.

Nesta direção, Cardoso (2012) resume claramente a relação da identidade contemporânea com o ambiente artificial, repleto de artefatos que configuram as interfaces com este contexto fluido, construindo a cultura material e imaterial da cena cotidiana atual.

\begin{abstract}
A identidade está em fluxo constante e sujeita à transformação, equivalendo a um somatório de experiências, multiplicadas pelas inclinações e divididas pelas memórias. Quando se pensa que o sujeito existe, ao longo de sua vida, rodeado por enunciados e informaç̧ões, produtos e marcas, design e projeto, começase a ter uma noção das múltiplas maneiras em que memória e identidade podem interagir para moldar nossa visão do mundo material e condicionar nossa relação com os artefatos que nos cercam (CARDOSO, 2012, p.92).
\end{abstract}

Essa reestruturação, ainda em curso, na qual a ordem social se fragmenta e o cenário previsível e estático se converte em um entorno dinâmico (BAUMAN, 2001), caracteriza o mundo complexo.

\footnotetext{
Complexus significa o que foi tecido junto; de fato, há complexidade quando elementos diferentes são inseparáveis constitutivos do todo (como o econômico, o político, o sociológico, o psicológico, o afetivo, o mitológico), e há um tecido interdependente, interativo e inter-retroativo entre o objeto de conhecimento e seu contexto, as partes e o todo, o todo e as partes, as partes entre si. Por isso, a complexidade é a união entre a unidade e a multiplicidade. Os desenvolvimentos próprios a nossa era planetária nos confrontam cada vez mais e de maneira cada vez mais inelutável com os desafios da complexidade (MORIN, 2001, p.38).
}

Diante deste cenário, no qual a individualidade é exaltada e as identidades sociais apresentam uma composição multifacetada, projetar artefatos e serviços requer o mesmo dinamismo. É pertinente inferir que os questionamentos atuais devem receber 
uma abordagem flexível e integrante. Sobre esse caráter interativo, Sanches (2010) aponta o pensamento de design como estratégia, considerando que a grande vantagem deste tipo de raciocínio é a visão panorâmica em interface com a capacidade de síntese integradora, ou seja, a competência sistêmica para interpretar, gerenciar e conectar variáveis, extraindo dessas interações a essência dos elementos envolvidos.

No mesmo sentido, Moraes (2010), considerando a complexidade do cenário atual, argumenta que decodificá-lo é um desafio, porém a natureza holística, transversal e dinâmica do design pode facilitar essa decodificação da realidade, auxiliando na definição de diretrizes que guiem as intervenções neste contexto híbrido. $\mathrm{O}$ autor chama a atenção para a ruptura da escala hierárquica das necessidades humanas ${ }^{44}$, argumentando que o atual contexto trouxe para os níveis primários a satisfação de necessidades relacionadas à estima e à realização pessoal, assinalando uma significativa mudança na absorção e relevância de valores subjetivos nas relações de uso e consumo de produtos. Desta forma, tais valores passaram a fazer parte dos requisitos para a concepção de produtos, o que faz presumir que sejam projetáveis. Para tanto, segundo Moraes $(2008 ; 2010)$, é imprescindível um distanciamento do âmbito tecnicista e linear, para dar lugar às interações com áreas que tratam dos fatores psicológicos e estésicos.

Para resumir, volta-se a Cardoso (2012), para o qual a complexidade atual pode ser entendida como "um sistema composto de muitos elementos, camadas e estruturas, cujas inter-relações condicionam e redefinem continuamente o funcionamento do todo" (CARDOSO, 2012, p. 25). A partir disso, o autor confirma, como Moraes (2010) e Sanches (2010), que a grande contribuição do design para o equacionamento dos desafios deste contexto é o pensamento sistêmico, já que poucas áreas estão habituadas a trabalhar de forma tão integrada e comunicante.

A partir das considerações anteriores, torna-se claro que investigar o Design de Moda neste cenário exige uma postura maleável e uma conduta integrada, especialmente em um campo em que os objetos são claramente um reflexo imediato das transformações socioculturais, imersos em um cenário regido pela variabilidade e

\footnotetext{
44 Abraham Maslow propõe uma hierarquia de cinco categorias de necessidades humanas, organizandoas em uma pirâmide - Pirâmide de Maslow - que mostra a sequência em que tais necessidades são satisfeitas. Em ordem de importância relativa, as cinco categorias de necessidades são: fisiológicas, de segurança, sociais, de status ou estima e de autorrealização.
} 
pela transitoriedade. Isto posto, a plataforma teórica para apreender meios de gestão projetual examinou as características do pensamento projetual para, posteriormente, evidenciar a abordagem sistêmica do projeto.

\subsection{OS PROCESSOS DO PENSAMENTO PROJETUAL}

-

Refletir sobre o projeto nas esferas educacionais reivindica uma sondagem acerca de como se desenrola o processo projetual. No caso desta pesquisa, essa exploração consistiu em identificar que características marcam os raciocínios que conduzem as ações de projeto, no intuito de inseri-las na concepção de meios para facilitar a prática projetual e a organização do conhecimento para direcioná-la.

Tendo em vista que os termos processo, método e técnica são vocábulos de presença indispensável em qualquer estudo sobre o ato projetivo, convém elucidar o sentido atribuído a eles nesta explanação.

Coelho (1999) explica que processo consiste na organização lógica de um sistema, representa a evolução sucessiva de estados desse sistema, constituindo a base estrutural dos métodos desenvolvidos em um projeto. Já o conceito de método sugere a ideia de "caminho para determinado fim". Em contraste com a noção de etapas do processo, métodos constituem o conjunto de procedimentos específicos que são adotados para conduzir cada etapa do processo. Entretanto, o método se adapta a cada projeto e não é fixado a priori, representa o saber adquirido no transcurso projetual, o conhecimento do modus faciendi transmitido sob a forma de técnicas. Desta maneira, processos compreendem métodos que, por sua vez, englobam técnicas, as quais envolvem competências e habilidades específicas para a execução do método. Por conseguinte, método é o conhecimento compreendido dentro de um processo e se expressa por meio da técnica (conhecimento aliado à prática). O mesmo autor pondera que as etapas de um processo podem coincidir com etapas metodológicas e previne que transformar um modelo de processo na apresentação de um método não é um problema em si, a armadilha está em repeti-lo como uma receita, um modelo hegemônico em que não há consciência da possibilidade de escolha dos caminhos a seguir. 
Desta perspectiva, os métodos constituem as estratégias, e as técnicas colocam em marcha a operacionalização. Todavia, na prática, essa distinção não é tão evidente. Cross (2000) qualifica como métodos todos os procedimentos, técnicas, ajudas ou "ferramentas" para projetar, aglutinando distintas atividades utilizadas e combinadas pelo designer durante um processo geral de design.

Pazmino (2010, p.177) entende que "os métodos no campo do design são instâncias intermediárias para a aplicação dos diversos saberes". Esta autora utiliza o termo para designar o conjunto de técnicas e ferramentas como meios auxiliares para o desenvolvimento de um projeto de produto.

Ponderando a variação de interpretações sobre o que se encaixa na definição de método, técnica ou simples recomendações de procedimentos, e considerando que as estratégias aqui tratadas podem aglutinar tais conceitos, a opção mais adequada parece ser a de Baxter (1998), que nomeou estes meios como ferramentas de projeto. Assim, nesta tese foram adotados os termos ferramenta, instrumental ou estratégia metodológica para denominar os meios utilizados para auxiliar e gerir o processo projetual.

Igualmente, é necessário ter a prudência de ressaltar que esquadrinhar definições concisas para o vocábulo projetar também pode não satisfazer a complexidade do tema, uma vez que o ato é marcado pela necessidade de adotar pensamentos e conhecimentos de natureza muito diversificada. Por conseguinte, decidiu-se não propor uma definição para o termo, mas demarcar o foco na análise processual, que ocorre entre a demanda (problema) e a proposta para atendê-la (solução), pontuando as ações de pensamento envolvidas no trajeto e extraindo diretrizes para a condução.

Para esta tarefa, é primordial distinguir algumas características desse movimento entre problema e solução. Neste curso, Dias e Gontijo (2006) destacam que, em um contexto multifacetado como o atual, é necessário analisar os problemas de design com lentes múltiplas, levando em conta o maior número possível de pontos de vista e de perspectivas de análise. Sanches (2011) também argumenta que a conduta de um projeto de Design de Moda é, em essência, um processo orgânico e dinâmico, já que os parâmetros da realidade que o aloja podem ser flutuantes. A partir das ponderações 
anteriores, inferem-se dois fatores importantes envolvidos no trajeto projetual: a incerteza e a diversidade de possibilidades.

Estes fatores estão sempre presentes no processo, uma vez que projetar presume a condição de antever o futuro, o planejamento de algo que ainda não se conhece, ou que não é plenamente conhecido. Por consequência, é improvável que o caminho trilhado entre o problema (pergunta) e a solução (resposta) de projeto seja previamente decretado. Na trajetória, as decisões se conectam umas às outras, a partir de uma rede dinâmica que vai assimilando novas informações e se modificando até delinear sua viabilidade. Além disso, segundo Sanches (2010), pode haver mais de uma probabilidade de resposta aos questionamentos que surgem durante o processo, mostrando que outras direções poderiam ser tomadas ou, ainda, que os parâmetros estabelecidos no início do trajeto não são estanques. Em vista destes aspectos, outro agente importante sobressai: o movimento.

Lawson (2011) infere que o pensamento projetual é marcado por um ciclo de avanços, retrocessos e deslocamentos do pensamento. Nesse fluxo cíclico e interativo, é pertinente deduzir que a coleta de informação é contínua, a retroalimentação das análises é constante e que, frequentemente, aparecem linhas paralelas de pensamento. Desta forma, o percurso projetual não pode ser entendido como um esquema fechado e linear de decisões. Em uma tentativa de representá-lo graficamente (Figura 10), é provável que se aproxime mais de uma estrutura multidimensional, com um núcleo focal, o qual se amplia ao receber novas informações e se afunila ao conectar essas informações para decidir o próximo passo em direção a uma resposta, compondo um sistema permeável às interações possíveis.

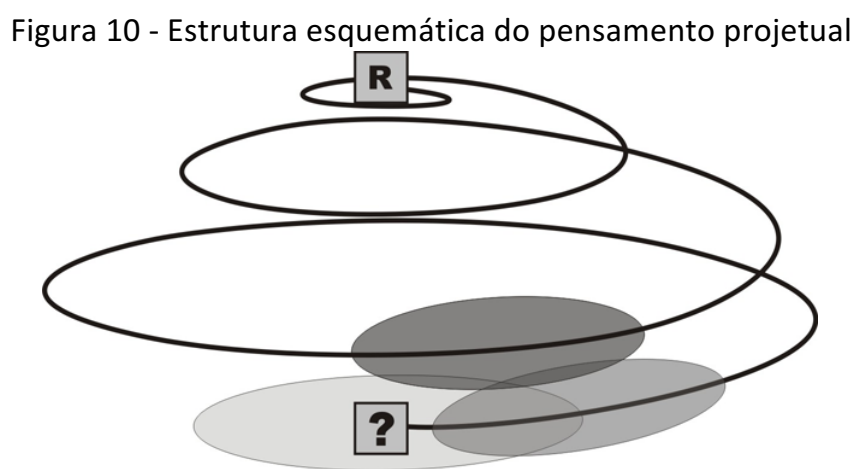

Fonte: Sanches (2010) 
Apesar das limitações de uma representação bidimensional, a imagem anterior se destina a ilustrar a percepção de um trajeto de raciocínio que pode se abrir a novas possibilidades indefinidamente ou promover novos movimentos do pensar. Deste modo, constrói-se um sistema em que os sujeitos envolvidos tomam decisões continuadamente sobre o caminho a seguir, tendo que lidar com os recorrentes ciclos que encadeiam análises, sínteses e avaliações (LAWSON, 2011; JONES, 1992).

Pelo exposto, percebe-se que é impraticável determinar uma trajetória padrão para o processo de design, bem como estabelecer, antecipadamente, uma sequência clara de passos a trilhar. No decurso, os limites entre problema e solução são difusos, já que muitas vezes não se pode compreender o problema sem uma primeira visualização de formas de resolvê-lo. Van Der Linden e Lacerda (2012) enfatizam esse ponto de vista nas vertentes teóricas, considerando improvável um trajeto linear para o processo projetual, "simplesmente porque são necessárias interações sucessivas para que o problema e a solução sejam modelados" (VAN DER LINDEN; LACERDA, 2012, p. 111).

Esse movimento do pensar projetual foi analisado por Lawson (2011, p.128), que assinala dois tipos de pensamento entrelaçados no ato projetivo: os pensamentos imaginativo e reflexivo. O pensamento imaginativo descrito pelo autor como "fantasia ancorada na realidade" é a faculdade de pensar em uma situação possível, mas não real. Em contrapartida, estaria o que se denomina comumente de "raciocínio", exercido de forma autoconsciente, na tentativa deliberada de controlar a direção dos pensamentos rumo a um fim pretendido, lidando com os obstáculos que se apresentam neste decurso. Este último definiria o pensamento reflexivo para resolver problemas. Não obstante, a combinação de pensamento racional e imaginativo constitui uma das habilidades mais importantes para projetar.

A despeito do pensamento imaginativo, normalmente, induzir a uma correlação imediata com o pensamento criativo, inegavelmente protagonista no processo de design, é raro encontrar situações projetuais em que apenas o pensamento imaginativo ou o racional sejam aplicados isoladamente. Esse equilíbrio dinâmico faz parte da preocupação de vários estudiosos do processo de design e do processo criativo. A ideia de um fluxo que alterna classes de pensamentos diversos, uma que dá espaço a intuição e explora pontos de vista alternativos, enquanto a outra é guiada pela lógica e a racionalidade, já foi examinada sob distintas óticas. É frequente, entre estas teorias, 
referendar os estudos do psicólogo Joy Paul Guilford sobre como se processa o pensamento criativo.

Guilford (1956 apud LAWSON, 2011) dividiu os fatores do pensamento em três categorias: cognição, a qual encerra os fatores que têm relação com tomar consciência e entender as classes de informações, objetos ou ideias, envolvendo a capacidade analítica de classificar e reconhecer ordenações (figurativas, estruturais ou conceituais); os fatores de produção tratam da capacidade de gerar e produzir tais ordens; a categoria avaliação inclui os fatores de julgamento, responsáveis pela comparação de itens de informação em termos de variáveis, julgamentos e decisões. Guilford (1967 apud ALENCAR; FLEITH, 2009; KNELLER, 1976) classifica, dentre os fatores de produção, duas categorias de capacidades: convergentes e divergentes. A primeira é acionada pelo pensamento que se move em prol de uma resposta determinada ou convencional, já as habilidades divergentes se relacionariam ao pensamento criativo, por se destinarem à produção de múltiplas respostas alternativas para uma questão.

Os fatores mencionados aclaram a compreensão do pensamento produtivo, referindo-se ao processo de controlar e dirigir o pensamento no rumo de um fim específico, sendo comumente estudado sob esta construção binária entre divergência e convergência. Proctor (2005) explica que o pensamento produtivo se subdivide em processos lógicos e intuitivos. O pensamento convergente é unifocal e usa a habilidade dedutiva e interpolativa para alcançar uma única resposta correta para um problema. Esta categoria de pensamento transita em universos fechados, em que os limites e as propriedades já são conhecidos e variam pouco. Em contrapartida, o pensamento divergente se move em dimensões múltiplas e simultâneas, suas habilidades se relacionam às abordagens abertas, buscando alternativas em que não há respostas nitidamente corretas e únicas.

Tschimmel (2003, p. 2) explica a teoria de Edward de Bono que, em semelhança à acepção de produção divergente, define o pensamento criativo como pensamento lateral em oposição ao pensamento vertical. O pensamento vertical é analítico, lógico, seletivo, se move em direção a um objetivo predefinido. Já o pensamento lateral corresponde a uma ruptura do pensamento habitual, em uma expansão sem ordem aparente, para buscar caminhos alternativos, relacionando elementos que a princípio 
parecem não ter qualquer ligação com o problema em si, por se caracterizar "como um processo de possibilidades, em vez de um processo com um objetivo predefinido".

Cross (2000) também salienta os estudos dos psicólogos sobre estas dicotomias, nos estilos de pensamento, os quais considera importantes para a estrutura de estratégias de design. $\mathrm{O}$ autor elenca, além dos pensamentos divergente e convergente, o lateral e o vertical ${ }^{45}$, os pensamentos dos tipos serial e holístico. O pensador serialista prefere os passos lógicos e esclarece cada ponto ou decisão antes de passar ao seguinte, preferindo uma ordem sequencial. Em contrapartida, o holístico processa vários elementos simultaneamente, atuando em visão panorâmica e relacionando informações que não necessariamente se conectam por uma lógica.

Percebe-se que o modo divergente é essencial ao processo criativo, contudo projetar também exige a convergência para chegar a um resultado. Tendo em vista "que raramente os projetos são procedimentos de otimização que levam a uma única resposta correta, o pensamento divergente será necessário. No entanto, é provável que, em qualquer processo de projeto, haja muitos passos que exijam tarefas convergentes." (LAWSON, 2011, p. 140). Da mesma forma, Cross (2000) e Tschimmel (2003) realçam as qualidades divergente e convergente do raciocínio projetual e observam que, embora os designers possam ter estilos cognitivos distintos, o êxito do projeto depende de aplicar estratégias que usufruam de ambas as formas de pensamento.

Jones (1992), sobre o mesmo arcabouço, identifica três grandes fases no processo de design: análise, síntese e avaliação. O autor afirma que em cada fase predomina uma modalidade de pensamento e classifica as etapas projetuais: a) divergência: inclui as ações para expandir os pontos de vista sobre o problema, gerar questionamentos e multiplicar os enfoques; b) transformação: dá margem à exploração estrutural do problema e à geração de conceitos criativos para estabelecer conexões em busca de uma solução; c) convergência: canalizam-se as ações para a definição de uma solução, reduzindo as incertezas por meio de estratégias de avaliação.

As ponderações anteriores confirmam as múltiplas facetas que assume o pensamento projetual. Entretanto, as discussões teóricas na área indicam um processo

\footnotetext{
${ }^{45}$ Cross (2000) denomina esta dicotomia como lateral e linear. Não faz referência a De Bono, ou a outra fonte, contudo a descrição do autor sugere a mesma interpretação.
} 
que articula simultaneamente racionalidade lógica e investigação heurística (LESSA, 2011, p.41), uma articulação indispensável aos ciclos de análise, síntese e avaliação.

[...] o projeto se desenvolve tendencialmente com base na associação entre a abertura dada pelo pensamento paralógico ${ }^{46}$ e o respaldo concomitante de avaliações e raciocínios lógicos, conjugando certa liberdade de operações e percurso, possibilitada pela heurística, e o controle racional necessário para o seu êxito (LESSA, 2011, p.48).

Diante da constatação do dinamismo e da diversidade que caracterizam o pensamento projetual, é natural que se levantem conjecturas sobre como gerir tal processo. A esse respeito, os autores que abordam a metodologia do design, na atualidade, parecem ser unânimes sobre a necessidade da maleabilidade dos métodos. Não obstante, Christofher Jones já argumentava nos anos setenta que as estratégias para operacionalizar o projeto deviam ser adaptadas às exigências de cada problema de design. Cross (2000) também declara que é necessário ter um enfoque estratégico flexível. O autor defende estratégias que identifiquem e promovam a classe correta de pensamento e no momento correto, dentro de um contexto particular de projeto.

Em face aos argumentos citados e considerando a já referida complexidade da realidade contemporânea, um quadro de raciocínios múltiplos é revelado. Por conseguinte, os problemas de design surgidos neste cenário solicitam ações integradas e passíveis de redirecionamentos, a partir da comunicabilidade de saberes, evidenciando um pensamento em transversalidade. Nessa linha de raciocínio, Lessa (2011), Burdek (2006), Moraes (2010), Vassão (2010) e Cardoso (2012) ratificam que a complexidade demanda abordagens mais amplas e não lineares para a conduta projetual, indicando que as metodologias para organizar a multiplicidade de variáveis precisam ser igualmente interativas e maleáveis.

Considerando que o projeto é caracterizado pela vinculação de inúmeras variáveis, articuladas em ações organizadas e interdependentes, para constituir uma totalidade integrada, não surpreende que o termo sistema seja, frequentemente, associado ao processo de design. Igualmente, os problemas complexos da atualidade e a confluência de aspectos sustentáveis expandiu o foco projetual para a busca de soluções em rede, reafirmando a noção de uma atuação sistêmica.

\footnotetext{
${ }^{46}$ Lessa (2011) enfatiza a ocorrência de formas de pensamento e cognição que se colocam além da lógica formal estrita, exaltando a heurística como meio de dar espaço para a um pensamento, sem controle excessivo, de caráter informal, intuitivo, especulativo, que trabalha com analogias e metáforas.
} 


\subsection{A ABORDAGEM SISTÊMICA}

A Concepção sistêmica vê o mundo em termos de relações e de integração. Os sistemas são totalidades integradas, cujas propriedades não podem ser reduzidas às unidades menores. Para abordar um fenômeno sob esta ótica, em vez de se concentrar nos elementos ou substâncias básicas, enfatizam-se princípios básicos de organização (CAPRA, 1986, p.259).

Em uma analogia com os sistemas naturais, Capra (1986) adverte que as propriedades sistêmicas são destruídas quando um sistema é dissecado, física ou teoricamente, em elementos isolados. Embora haja a distinção de partes individuais em qualquer sistema, a natureza do todo é sempre diferente da mera soma das partes. 0 autor destaca que um sistema é intrinsecamente dinâmico, não possui uma estrutura rígida, "mas manifestações flexíveis, embora estáveis, de processos subjacentes" (CAPRA, 1986, p.261). A abordagem sistêmica enfatiza mais as relações do que as entidades isoladas, percebendo que essas relações são inerentemente dinâmicas e fluidas. O pensamento sistêmico é pensamento de processo, no qual a forma manifesta do sistema associa-se ao processo, a inter-relação à interação, e os opostos são unificados por meio da oscilação.

\footnotetext{
O aspecto processual do pensamento sistêmico decorre da centralidade das interações. Para o pensamento sistêmico as estruturas são vistas como manifestação de processos subjacentes [...] Estruturas sistêmicas são estabilizações temporárias de relações e processos que persistem, e não o resultado das propriedades dos componentes estruturais isolados que the servem de suporte (KASPER, 2000, p.51).
}

Capra (1986) ainda explica que pensar sistemicamente envolve uma conexidade de relações e de contexto. Em oposição ao pensamento cartesiano, caracterizado pela noção de que em qualquer sistema complexo o comportamento do todo podia ser compreendido ao desmembrar e analisar as propriedades de suas partes, a teoria sistêmica entende que os sistemas vivos não podem ser compreendidos por meio da análise (no sentido de reducionismo) das propriedades das partes, pois não são propriedades intrínsecas, só podem ser compreendidas dentro do contexto do todo maior. O pensamento sistêmico é pensamento contextual e, "uma vez que explicar 
coisas considerando o seu contexto significa explicá-las considerando o seu meio ambiente, também podemos dizer que todo pensamento sistêmico é pensamento ambientalista" (CAPRA, 1996, p.46).

Vasconcellos (2009), apoiada nos estudos de Humberto Maturana e Francisco Varela, compartilha essa ótica contextual e processual, mas enfatiza a presença do sujeito (observador) na contextualização de um sistema. A autora explica que, pela forma como se estrutura biologicamente o conhecer humano, é improvável um conhecimento objetivo do mundo, reconhecendo que a "realidade" emerge das distinções feitas pelo observador. Ao contextualizar um fenômeno, ampliando o foco, o observador pode perceber as circunstâncias envolvidas, percebendo relações intrassistêmicas e intersistêmicas, potanto verá uma teia de fenômenos interligados e terá diante de si a complexidade do sistema.

A complementariedade entre um pensamento processual e contextual descrita por Capra (1996; 1986), agregada à consciência da presença de um observador (VASCONCELLOS, 2009), confirma a evidência sistêmica do processo projetual, cuja existência é dependente da percepção e organização de conexidades distinguidas pelo designer (sujeito do conhecimento/observador). Para Vasconcellos (2009), distinguir as conexões e articulações é uma característica da forma sistêmica de pensar.

Nesta linha de raciocínio, quando se explora uma demanda de design, com o objetivo de sintetizar parâmetros norteadores para a prática projetual, a busca por informações é, simultaneamente, um exercício de distinção de unidades e de articulação de conjuntos. As informações coletadas só fazem sentido no contexto do projeto, quando percebidas em suas múltiplas interações. Assim, o processo projetual se manifesta a partir de uma trama interativa flexível, em que as estruturas de organização adquirem autonomia como sistema, mas se mantêm permeáveis as trocas com o meio.

No centro dessa formulação surge a noção de processos de análise e síntese. Capra (1986) concorda que a descrição das partes (análise) e a identificação de um conjunto integrado (síntese), proporcionado pela visão holística, são enfoques complementares que, se usados com equilíbrio, ajudam a alcançar um conhecimento mais profundo da vida. Contudo, vale lembrar que a finalidade das análises no decorrer do processo projetual não é isolar as propriedades dos componentes, mas distingui-las para entender as relações com o sistema, o que aproxima o pensamento projetual das 
recomendações de Morin (2003, p.89), alertando que é "preciso substituir um pensamento que isola, por um pensamento que distingue e une. É preciso substituir um pensamento disjuntivo e redutor por um pensamento do complexo, no sentido original do termo complexus: o que é tecido junto". Ainda que Morin denomine este tipo de pensamento como complexo, a base epistemológica dos argumentos de Vasconcellos (2009), que caminha pela linha das abordagens sistêmicas organicistas e assimila o pano de fundo da complexidade, aproxima os conceitos de complexo e sistêmico.

Cardoso (2012) afirma que a prática do pensamento sistêmico no design é a capacidade de avaliar os acontecimentos ao seu redor e as suas possíveis implicações, a fim de criar uma solução integrada que possa contemplar as expectativas de todas as partes envolvidas.

Neste ponto, o leitor poderia perguntar se a articulação de ideias versa sobre o modo de pensar do designer ou sobre os modos de gerenciar as atividades do projeto. O fato é que os dois estão atrelados e, muitas vezes, se fundem nas análises, já que investigar o trajeto do raciocínio também implica entender sobre que condutas ele avança. Por isso, no momento, não interessa isolar um ou outro, mas realçar que o desenvolvimento do raciocínio projetual na formação passa pela conexão entre o pensar e o agir sistemicamente.

Sob esta perspectiva, os procedimentos realizados no transcurso do projeto adquirem também uma natureza sistêmica, em que se observa um conjunto de elementos inter-relacionados e interdependentes, no qual o comportamento de cada um afeta e depende do estado geral do conjunto e as vinculações são estabelecidas em prol de um objetivo comum. Porém, no caso do design, as inter-relações não estão restritas, exclusivamente, a um conjunto fechado de componentes, visto que as ações projetuais estão em comunicação constante com o ambiente em que se desenvolvem. Esta visão sugere que o processo origina um sistema permeável às interações contextuais, pelo qual se pondera o artefato desenvolvido no composto de interações (relações humanas, cultura material, mercado) em que este se insere.

Todas as considerações pregressas confirmaram a pertinência de uma abordagem sistêmica no andamento da pesquisa. Além de contemplar a possibilidade de um tratamento não linear e maleável para o instrumental metodológico utilizado na unidade curricular específica (Metodologia do Projeto), esse enfoque facilita o trânsito 
entre as outras unidades e pode respaldar a integração de saberes propostos pelo projeto pedagógico do curso em questão.

Para tanto, dois conceitos subjacentes são detectados no universo estudado: a prática reflexiva e o metaprojeto. A esse respeito, os estudos de Schön (2000) e Lawson (2011) confirmam que a formação profissional do designer deve propiciar a prática reflexiva. No entanto, há dois tipos de reflexão na prática projetual: refletir na ação e refletir sobre a ação. No primeiro processo, o designer reflete continuadamente sobre o entendimento do problema e a validade das soluções que vão surgindo. Todavia, o segundo tipo de reflexão envolve um afastamento mental e uma visão panorâmica para perguntar se o processo caminha bem ou deve ser levado em outra direção. Neste nível, o aprendizado do projetista se estende sobre os meios que utiliza para gerir o pensamento projetual, proporcionando a ampliação do seu conhecimento tácito.

Essa premissa indica que a aprendizagem requer uma "análise do próprio processo de projeto", recaindo de forma inevitável em um olhar sobre o conceito de metaprojeto proposto por Moraes (2010) e Franzato (2012).

Moraes (2010) define metaprojeto como o percurso que precede o projeto no sentido operativo; seu objetivo é delinear um cenário de hipóteses projetuais, por meio da investigação do sistema de relações contextuais que envolvem o projeto em desenvolvimento. Trata-se de uma visão crítica e reflexiva preliminar sobre o próprio projeto, incidindo em uma plataforma de conhecimentos e estratégias que, segundo o autor, se apresentam como suporte para um trajeto projetual flexível, de verificações contínuas e decisões reversíveis. Franzato (2012) afirma que esta abordagem também estimula uma reflexão ulterior, conscientizando os atores envolvidos no processo sobre o significado do projeto, o que, de acordo com o autor, suplementa a reflexão-na-ação. Nesta visão, o metaprojeto estimularia a reflexão-sobre-a-ação.

Entretanto, para atuar assim é imperativo criar um ambiente pedagógico propício. Com este intuito, o tópico subsequente resume o alicerce teórico que conduziu a postura didática praticada na interação em campo. 


\subsection{APRENDIZAGEM SIGNIFICATIVA}

A inserção desta pesquisa no ambiente educacional exigiu um posicionamento didático para a interação em campo. Foi necessário determinar os fundamentos e os meios para conduzir os processos, em sala de aula, incluindo, além do instrumental devido para realizar os procedimentos pedagógicos, uma plataforma para as relações ensinarapreender e aluno-professor.

Convém relembrar que, no contexto estudado, a interdisciplinaridade já é uma meta proposta pelo Projeto Pedagógico do Curso. Ao estudar o dia a dia da prática interdisciplinar, Leis (2005) destaca Bernstein (1983 apud LEIS, 2005), o qual reivindica que o conhecimento deve ser empírico, interpretativo e crítico ao mesmo tempo. Esta proposta ratifica a essência do que se pretende alcançar nas vivências relatadas no capítulo 1 , nas quais a pesquisa, a experimentação concreta e a interação de conceitos e interpretações promovem a construção integrada do conhecimento. Entretanto, a interpenetração de conteúdos e a evolução contínua do conhecimento vivenciado demonstram a relevância do pensamento sistêmico para a gestão do projeto, já que os métodos utilizados também podem interagir e se transformar no transcorrer da dinâmica do ambiente em questão.

A presente investigação não tem a intenção de discutir as teorias da educação superior. Entretanto, é preciso destacar referenciais que se conectam ao ensino de projeto, pela sua afinidade com o pensamento sistêmico e a integração de saberes próprios do pensamento de design.

Anastasiou (2012a; 2012b) argumenta que houve uma ruptura na forma de ver a ciência, delineando aquilo que a autora denomina visão pós-moderna. Essa mudança paradigmática promoveu recorrentes esforços, nos ambientes acadêmicos, em prol de ações pedagógicas e organizações curriculares mais integrativas, uma vez que a nova visão discute fatores que abalam a estabilidade determinista. Conceitos como simultaneidade, incerteza, não linearidade e a mobilidade adaptativa dos processos aos contextos influenciaram os estudos sobre a produção de conhecimento e saber escolar. A autora realça que o conhecimento é construído sob uma abordagem relacional, mais flexível e complexa, resultando em uma apropriação ativa e dinâmica dos conceitos e 
suas aplicações práticas. Neste sentido, a formação compreende uma valorização de processos e não apenas de produtos (resultados).

\begin{abstract}
Para construir o conhecimento em uma universidade, na interação de processo e produto, considera-se que construímos, assimilamos e acomodamos, pela experiência e comparação do dado novo com o que já temos elaborado e adquirido formal ou informalmente, espontaneamente ou com objetivos específicos. [...] Nas Instituições de ensino, o saber escolar [grifo da autora] é objeto de transferência e construção de sínteses progressivamente mais complexas, em grupos e ambientes definidos, integrando o conhecimento sistematizado com o conhecimento do estudante e visando ao aprofundamento da experiência e à produção e reconstrução do conhecimento (ANASTACIOU, 2012b, p.55).
\end{abstract}

Nesta direção, a mesma autora menciona uma pesquisa com docentes universitários, na qual sintetizou a concepção sobre a construção de conhecimento em sala de aula. Nesta visão, o conhecimento deriva da investigação científica em interação com a realidade observada e vivenciada. Assim, a absorção e a percepção cotidiana do meio, que formam a base cognitiva dos indivíduos, atuam como plataforma para a construção do novo, reelaborado por meio das inter-relações estabelecidas entre meio social, cultural e educativo, associando experiências, descobertas e informações.

Ainda com base nas afirmações de Anastasiou (2012a; 2012b), percebe-se pelo uso dos termos assimilação e acomodação, a influência da teoria piagetiana. Moreira (1999) e Pádua (2009) explicam que, ao abordar a realidade, o sujeito extrai informações e incorpora aquelas que se adequam aos seus esquemas mentais (esquemas de ação), ocorrendo uma integração a essas estruturas. Por vezes, o objeto/situação apresenta propriedades singulares, estranhas aos esquemas de assimilação existentes na estrutura cognitiva do indivíduo; neste caso, a mente desiste, ou se modifica. Havendo modificação, ocorre o que Piaget, conforme Moreira (1999) e Pádua (2009), denominou de acomodação, quando a mente cria novos esquemas e se reestrutura. Por conseguinte, os processos de assimilação e acomodação, originando novos esquemas mentais, promovem uma busca por um novo equilíbrio das estruturas que se modificaram para se acomodar, ao qual se nomeou equilibração. Logo, a construção do conhecimento é um processo dinâmico, de equilibração (assimilação e acomodação) contínua. Apesar das teorias de Piaget não se referirem, especificamente, à 
aprendizagem, os conceitos de assimilação, acomodação e equilibração influenciaram a maior parte dos estudos construtivistas sobre aprendizagem.

A filosofia construtivista, de acordo com Moreira (1999), é cognitivista e interpretacionista e enfoca a construção da estrutura cognitiva, estudando como um indivíduo conhece o entorno, sob a premissa de que os objetos e eventos do contexto são interpretados pelo sujeito cognoscente. No ambiente escolar, isto significa atribuir ao aprendiz o papel de agente na construção de sua própria estrutura cognitiva.

Em vista disso, o processo de aprendizagem não é passivo e depende da interação continuada entre aluno e professor. Anastasiou (2012a), ponderando esse aspecto colaborativo, discute os termos ensinar e aprender/apreender. Para a autora, ensinar é mais que a simples transmissão de informação, o verbo ensinar tem duas dimensões, uma utilização intencional e outra de resultado, portanto, para que o ensino se efetive, o processo deve se completar com a apropriação do conteúdo por parte do estudante. Em contrapartida, essa apropriação está vinculada à aprendizagem, que a autora associa ao conceito de apreender, no lugar de aprender.

Analisando a etimologia dos termos, Anastasiou (2012a) resume que aprender significa tomar conhecimento, receber a "informação de...", apontando uma relação passiva entre sujeito e conhecimento. Por outro lado, apreender significa segurar, agarrar, assimilar mentalmente, compreender, sugerindo a ideia de atividade, de tomar para si, apropriar-se. Nesta linha de raciocínio, ela cunha o termo ensinagem, no qual está implícita a noção de envolvimento integral dos sujeitos (professor e aluno) na construção do saber escolar.

Para tanto, é importante exercitar "um saber o quê, um saber como, um saber por quê e um saber para quê" (ANASTASIOU, 2012a, p.20), propondo uma unidade dialética ${ }^{47}$ processual, na qual o papel condutor do professor e a autoatividade do estudante se efetivem em mão dupla e propiciem a interligação do aluno ao objeto de estudo. Em vista dessas considerações, o termo ensinagem foi adotado nesta investigação, por sua conotação de corresponsabilidade, quando a ideia for enfatizar o processo conjunto ensino/aprendizagem.

\footnotetext{
47 “Uma metodologia na perspectiva dialética entende o homem como um ser ativo e delações [...] e que o conhecimento é construído pelo sujeito na sua relação com os outros e com o mundo." (VASCOCELLOS, 1995 apud ANASTASIOU, 2012a)
} 
O posicionamento inicial de um saber construído com base nas possibilidades compartilhadas entre aluno e professor, que sustentava esta pesquisa na fase exploratória, adquiriu corpo e uma diretriz concreta, em 2014, quando uma das professoras da instituição examinou o mesmo universo aqui enfocado, por ocasião de seu estudo de mestrado. A referida pesquisa abordou o ensino de projeto no Design de Moda e indicou as teorias de David Ausubel, sobre Aprendizagem Significativa, como estratégia pertinente ao contexto examinado. Diante da sintonia entre as pesquisas e em virtude da participação de referida professora como docente da disciplina de Metodologia do Projeto, a partir do ano de 2013, essa vertente foi assumida como pressuposto. Deste modo, destacam-se na sequência os principais fundamentos desta teoria.

Miotto (2014) e Moreira (1999) situam a aprendizagem significativa entre as correntes construtivistas, as quais destacam o papel ativo do aprendiz e o enfoque na cognição individual, estudando os processos mentais envolvidos na capacidade de armazenar, transformar e aplicar o conhecimento. O enfoque cognitivista relaciona a atividade de apreender com a capacidade do sujeito em significar um estímulo, articulando-o com o repertório cognitivo, para assim solucionar as novas questões envolvidas no processo de aprendizagem.

\footnotetext{
Minguet (1998) e Pozo (1998) dividem a escola cognitivista em quatro grandes correntes teóricas que, embora tenham se desenvolvido a partir de diferentes objetivos de estudo, colocam os aspectos cognitivos individuais como centro de suas pesquisas. As teorias da percepção, proposta pela psicologia da Gestalt; da equilibração, desenvolvida por Piaget; da mediação, estudada por Vygotsky; e da aprendizagem significativa, conduzida por Ausubel, formam, segundo os autores, os pilares estruturais do Cognitivismo. (MIOTTO, 2014, p.27; SANCHES et al., 2016, p.14)
}

Estas teorias, conforme Valente (2002), demarcam a noção de que a aprendizagem é construída por meio de interações constantes entre o sujeito que aprende, o objeto do ensino e o ambiente externo, sendo diferenciadas pelo foco dado a cada um dos elementos presentes no processo de ensino. Dependendo da abordagem e das estratégias adotadas pelo professor, a preponderância de um elemento sobre outro pode exercer função de dominação ou de inter-relação, privilegiando desde a 
construção de competências particulares do sujeito, até a transformação social do ambiente pelo processo de aprendizagem.

Ao discutir tais teorias, Miotto (2014) resume que, enquanto a psicologia da Gestalt investiga a percepção de sistemas holísticos e suas inter-relações no processo de construção do conhecimento, a teoria piagetiana afirma que, para conhecer um fato ou objeto, é necessário agir sobre ele, modificando o seu significado e entendendo como ele é construído. Enquanto os pensadores destas correntes entendem o desenvolvimento como algo que ocorre por meio da ativação das estruturas cognitivas do indivíduo, a teoria de Vygotsky marca a referência ao meio sociocultural e faz menção às instruções como parte do processo de construção do conhecimento. Assim, o instrutor passa a ocupar papel fundamental durante a aprendizagem. Neste sentido, Ausubel propõe que, durante o processo de aprendizagem, além do conteúdo abordado pelo professor, os conhecimentos prévios do aluno sejam valorizados, contribuindo na construção das estruturas e dos esquemas mentais, possibilitando uma aprendizagem prazerosa e eficaz.

Ausubel (2003) desenvolveu a teoria da aprendizagem significativa, em que o cerne é relacionar o objeto de estudo aos conhecimentos já estabelecidos na estrutura cognitiva do aluno. Moreira (1999; 2000) explica que as conexões com o conhecimento prévio não são arbitrárias, ou seja, não são estabelecidas com qualquer aspecto da estrutura cognitiva, mas sim com conhecimentos especificamente relevantes para o objeto de estudo. Estes aspectos específicos, denominados por Ausubel como subsunçores, atuam como "ancora" inclusiva para a nova informação. Assim, o conhecimento prévio funciona como "matriz ideacional e organizacional" para a incorporação de novos conhecimentos, quando estes se ancoram aos conhecimentos que lhes são pertinentes (subsunçores), preexistentes na estrutura cognitiva (MOREIRA, 2000, p.2).

Ausubel (2003) acredita que a mente organiza as informações em uma hierarquia conceitual, em que conhecimentos mais específicos se ligam a conceitos mais gerais e inclusivos. A estrutura cognitiva, em suma, consiste em uma estrutura hierárquica de conceitos que são representações das experiências sensoriais do indivíduo. A assimilação de uma nova informação, pela estrutura cognitiva existente, promove a 
transformação simultânea do conhecimento adquirido e, também, daquele que o ancorou (subsunçor).

$\mathrm{Na}$ aprendizagem significativa, o mesmo processo de aquisição de informações resulta numa alteração quer das informações recentemente adquiridas, quer do aspecto especificamente relevante da estrutura cognitiva [subsunçor], à qual estão ligadas as novas informações. (AUSUBEL, 2003, p.3, grifo nosso).

No campo da moda, por exemplo, o conceito de linguagem poderia já estar presente na estrutura cognitiva de alunos, podendo ser usado como subsunçor para introduzir o conceito de código estilístico. Contudo, durante o processo, o subsunçor linguagem também seria ressignificado, tomando maior amplitude e criando outras possibilidades de inclusão de novos conceitos específicos.

\begin{abstract}
À medida que o sujeito adquire conhecimento em várias áreas de conteúdo, estas organizam-se numa estrutura cognitiva relacionada com cada área. 0 melhor modo de se obter nova informação, a partir da estrutura cognitiva, é assimilá-la como parte da estrutura existente por um processo de conexão. Esse processo está envolvido no relacionamento de uma ideia nova com um conceito prévio e, ao mesmo tempo, na modificação de ambos, isto é, dando significado a ambos (VASCONCELLOS; ALMEIDA, 2003, p.15).
\end{abstract}

Pazmino (2010) corrobora a pertinência dessa abordagem ao ensino de design e destaca o papel do professor no processo. A este respeito, Moreira (1999) aponta quatro tarefas fundamentais para o docente:

A) Identificar a estrutura conceitual e proposicional da matéria de ensino (objeto de estudo), organizando os conceitos e princípios unificadores hierarquicamente, para estabelecer a progressividade de diferenciação (do conceito mais inclusivo e geral para os específicos).

B) Identificar os subsunçores relevantes para a vinculação do novo conhecimento.

C) Diagnosticar o conhecimento preexistente - determinar, dentre os subsunçores relevantes, os que já estão disponíveis na estrutura cognitiva dos alunos.

D) Utilizar recursos que facilitem a assimilação da essência conceitual da matéria, de modo significativo. 
Para auxiliar concretamente essa conexão com os subsunçores, segundo Moreira (1999) e Pazmino (2010), recomenda-se o uso de organizadores prévios. São materiais instrucionais introdutórios, utilizados com o propósito de manipular a estrutura cognitiva dos alunos, criando uma ponte cognitiva entre os novos conceitos e o conhecimento já existente. Este tipo de material é apresentado antes do material referente ao objeto de estudo propriamente dito, possui um nível mais alto de abstração, generalidade e inclusividade, e visa auxiliar a percepção ou reativação de conceitos mais abrangentes, com os quais se possam estabelecer relações explícitas entre os conhecimentos prévio e novo. Ausubel (2003) justifica que apresentar os organizadores, em um nível mais elevado de generalidade e de inclusão do que os materiais a serem apreendidos, é uma forma de lidar com a variedade de aprendizes, visto que cada um possui uma estrutura cognitiva de algum modo idiossincrática.

No entanto, para que a aprendizagem significativa se efetive, são necessárias duas condições: a primeira diz respeito à predisposição do aprendiz em apreender significativamente, já que assimilar novos processos exige esforço, e a segunda relaciona-se ao material utilizado durante a instrução do aprendiz, que deve ser potencialmente significativo, lógica e psicologicamente, ou seja, seus elementos conceitos, figuras, esquemas - devem estar organizados em estruturas lógicas de acordo com a natureza dos conteúdos, para que cada aprendiz imprima a leitura sobre eles e construa os significados psicológicos da nova informação (POZO, 1998; PELIZZARI, et al., 2002).

Moreira (1997) analisa que a teoria de Ausubel influenciou diversos pesquisadores da educação e infere que, se for ponderado seu componente de valorização do sujeito na construção do conhecimento, o conceito de aprendizagem significativa subjaz às teorias construtivistas. O mesmo autor destaca Joseph Novak, o qual defende a aprendizagem significativa e agrega o componente afetivo ao processo. De acordo com Moreira (1997, p.12), Novak considera o aprendiz de modo integral, seres humanos que pensam, sentem e agem, portanto um evento educativo é "uma ação para trocar significados (pensar) e sentimentos entre aprendiz e professor". Com base nesta colocação, quando se afirma que o estudante precisa ter predisposição para a aprendizagem, pode-se deduzir que está implícita a premência de um contexto 
educacional favorável, em que estão inclusos o ambiente e os relacionamentos interpessoais.

Predisposição para aprender e aprendizagem significativa guardam entre si uma relação praticamente circular: a aprendizagem significativa requer predisposição para aprender e, ao mesmo tempo, gera este tipo de experiência afetiva. Atitudes e sentimentos positivos em relação à experiência educativa têm suas raízes na aprendizagem significativa e, por sua vez, a facilitam (MOREIRA, 1997, p.12).

Para os cognitivistas o processo de construção de conhecimento se origina na formação de $\operatorname{conceitos}^{48}$, que está relacionada à capacidade do sujeito em significar o estímulo, bem como em relacionar tais conceitos com as experiências e conteúdos aprendidos anteriormente. Na abordagem humanista, Novak (2000) esclarece que conceitos são combinados para formar declarações ou proposições. O conhecimento armazenado no cérebro é composto de redes de conceitos e proposições. Assim, o significado de um conceito deriva da totalidade das proposições preexistentes ligadas a ele, além das conotações emocionais associadas a tal conceito, derivadas, em parte, das experiências e do contexto da aprendizagem, no momento em que foi adquirido.

Desta perspectiva, ponderando que o processo projetual depende da gestão de informações e conhecimento, percebe-se a aproximação com as convicções de Mozota (2011), que vê o design como uma atividade interdisciplinar e coordenativa, em que os conceitos devem ser adquiridos, combinados e transformados. Logo, ao examinar que essa transformação de conceitos requer a organização e integração do conhecimento à estrutura cognitiva do projetista, infere-se que as bases da teoria da aprendizagem significativa consistem em uma boa estratégia pedagógica para a ensinagem de projeto. Tal plataforma certamente ajudará o desenvolvimento de uma estrutura para raciocínios autônomos e propícios às interconexões, visto que o aprendiz estará,

\footnotetext{
48 O conhecimento do indivíduo sobre os seres e os objetos está constituído pelo que se denomina conceito. Segundo Fialho (2001 apud MIOTTO, 2014), a psicologia entende o conceito como um categorizador que permite falar de um mesmo objeto para diferentes níveis de generalidade. Ao categorizar, o sujeito estará classificando os conceitos, sendo que classificar pode ser entendido como associar um determinado elemento a uma classe; assim, o conceito é uma entidade cognitiva de base, que permite associar um sentido às palavras que utilizamos. (FIALHO, 2001, p. 111 apud MIOTTO, 2014, p.23). É importante ressaltar que o termo conceito gerador, utilizado no Capítulo anterior, embora contemple essa ideia categorizadora, vinculando elementos que partilham uma mesma essência representa a amplitude do vocábulo, quando usado neste tópico.
} 
continuamente, empenhado em organizar a estrutura cognitiva à assimilação de novos estímulos e apropriação de conhecimentos.

$\mathrm{Na}$ ação transformadora, o estudante exercita a competência integrativa, sendo capaz de interpretar, de gerenciar e de entender a essência dos elementos que compõem as variáveis do projeto, de acordo com as referências já estabelecidas em estrutura cognitiva. Miotto (2014) ratifica e alerta que ensinar projeto não se resume à demonstração das possibilidades previstas nas fases metodológicas do projeto, propondo a utilização arbitrária de ferramentas e técnicas para alcançar resultados esperados. A ensinagem de design:

encontra-se em um escopo que deve unir, assim como proposto na teoria da aprendizagem significativa, os conhecimentos já existentes na estrutura cognitiva do aluno aos novos conteúdos adquiridos durante a execução do projeto, para que se possa alcançar a inovação pretendida com esta atividade (MIOTTO, 2014, p.36).

Esse movimento de integração de conhecimentos se viabiliza no decorrer dos ciclos dos pensamentos divergentes e convergentes do processo de design, especialmente ao explorar e desvendar as conexões por meio da investigação do problema de projeto. A este respeito, Van Der Linden e Lacerda (2012) assinalam que a exploração do problema ocorre de modo cognitivo, não verbal e fluido.

Portanto, é premente integrar a visão panorâmica à capacidade de síntese, permitindo a fluidez da propagação das ideias e a cognição rápida, bem como propiciar a convergência para a construção de conceitos. Nesta direção, atualmente, várias pesquisas e práticas em design exaltam ferramentas integradoras mais ágeis e intuitivas para gerir as variáveis do projeto. Abordagens acerca de metadesign (VASSÃO, 2010) e metaprojeto (MORAES, 2010), bem como a divulgação de modelos flexíveis, como os do Design Council e do IDEO (VAN DER LINDEN; LACERDA, 2012), difundiram o uso de representações topológicas e do pensamento visual para a exploração e a estruturação de problemas de design, legitimando a relevância de formas menos descritivas para gerir as informações no processo projetual.

Seguindo a indicativa de utilizar o pensamento visual como meio de facilitar o dinamismo e a fluidez na conexão das informações e, consequentemente, construir novos conhecimentos, o estudo adentrou as teorias sobre este tema. 


\subsection{O PENSAMENTO VISUAL}

De acordo com Motta (2010), a instantaneidade caracteriza a comunicação na atualidade. O momento contemporâneo é marcado pela profusão de imagens em movimento; até os textos escritos e a convivência comunitária assimilam essa influência audiovisual em seus processos comunicativos. No entanto, em termos de cognição, a apreensão do mundo pelo canal imagético é algo inerente à neurofisiologia humana. Motta (2010) confirma que as representações imagéticas são responsáveis por grande parte da viabilização do raciocínio humano. Elas consistem no principal conteúdo do pensamento, independente da "modalidade sensorial" que a gerou e de se referirem a uma coisa ou a um processo. (DAMASIO, 1996, p.36 apud MOTTA, 2010, p.120). Nesta direção, Dondis (1997) menciona uma "inteligência visual" e a capacidade humana de se comunicar em um plano não verbal. Em vista desse papel determinante da visualidade, esta autora defende a relevância de se inserir, no percurso educativo profissional, a formação de um repertório para manejar a linguagem visual.

Na mesma direção, Gomes (2001 apud SANCHES, 2012) reforça que a expressão visual é essencial para o designer, visto que a clarificação de uma ideia fica mais próxima na medida em que ela se torna concreta, ou seja, a visualização das abstrações poderá desencadear a associação de ideias. Bürdek (2006) também valoriza as ferramentas de visualização como estratégia de síntese e comunicação, tendo em vista que, muitas vezes, a descrição verbal de objetivos, de conceitos e de soluções não é suficiente.

Embora o uso de imagens seja bastante difundido no ensino de projeto, as metáforas visuais, usadas em geral para representar o componente simbólico do projeto, não são a única maneira de aproveitar esse canal de expressão e organização cognitiva.

Eppler e Burkhard (2004) investigam os benefícios do uso de representações visuais para transferência e produção de conhecimento. Estes autores cunharam o termo "visualização do conhecimento" e consideram que o campo ainda é muito recente. Em suas pesquisas, fusionam teorias sobre visualização de informação, técnicas didáticas, cognição visual e comunicação visual, bem como abordagens mais práticas, tais como planejamento de negócios ou linguagens de programação visual. Os autores 
direcionam seus estudos principalmente para o uso na gestão de organizações, mas destacam também o emprego da visualização do conhecimento nas atividades criativas, tendo em vista que este meio oferece a possibilidade de rearranjos fluidos e a conexão de ideias coletivas.

Segundo Eppler e Burkhard (2004) e Eppler (2013), a maioria das atividades cerebrais lida com o processamento e análise de imagens visuais. Conforme os autores, muitos estudos empíricos já mostraram que as representações visuais são mais eficazes que as verbais em diferentes tarefas, uma vez que a capacidade do canal de entrada de estímulos é maior, quando são usadas as habilidades visuais.

Qualquer problema, segundo Roam (2010), pode ser resolvido com o auxílio do "pensamento visual". Isso significa aproveitar a grande atuação do sentido visual na percepção humana, usando três ferramentas inatas: o olho (captar); o olho da mente (perceber/ interpretar); a coordenação entre olho e mão (expressar/refinar/comunicar). O autor defende que pensar visualmente pressupõe trilhar quatro passos, a saber:

A) OLHAR: apreciação panorâmica e pré-seleção aleatória de informações.

B) VER: seleção e agrupamento das informações, baseada na compreensão de padrões.

C) IMAGINAR: manipulação da informação, percepção de novas conexões.

D) MOSTRAR: expressão e comunicação para clarificação e análise das sínteses efetuadas.

Ainda que os referidos passos fluam naturalmente, não se trata de um processo linear. Ocorrem de maneira cíclica e simultânea, pois olhar e ver se alimentam mutuamente e, ao imaginar e mostrar, um novo ciclo de percepções pode iniciar-se, tanto para os autores das ideias, quanto para outros colaboradores envolvidos na busca pela solução do problema.

Para o registro e a gestão das informações, Roam (2010) exalta o desenho manual, esquemas gráficos que podem incluir imagens, palavras e sinais gráficos indicativos de relações. $O$ autor também recomenda o uso de perguntas-chave (O quê? Quem? Onde? Quando? Como? Por quê?), tanto para reduzir, quanto para ampliar o nível de informação sobre o problema. 
Sobrepondo o trabalho de Roam (2010) às esferas das metodologias de design e da pedagogia construtivista, percebe-se que as referidas questões indicam as variáveis fundamentais para delimitar o contexto projetual e podem estimular a interação entre OLHAR e VER na exploração divergente do problema, deflagrando diretrizes para a busca de novas informações e construção de conhecimento.

Vassão (2010) também endossa o uso de representações topológicas como veículo para compreender o arranjo de conexões do sistema projetual. Neste caminho, o autor citado destaca as representações diagramáticas para facilitar a organização do pensamento, estabelecendo-as como base para a criação de ferramentas como Mapa Mental e Mapa Conceitual. Esses esquemas intermedeiam a percepção de relações de dependência entre entidades de um sistema, podendo delimitar estruturas de relações hierárquicas ou não hierárquicas. Por sua vez, Tony Buzan dissemina o uso de Mapas Mentais como facilitadores da aprendizagem.

Da mesma perspectiva, Ontoria et al. (2008) enfatizam que um mapa mental é uma poderosa ferramenta gráfica, em que se expressa o pensamento irradiante, uma qualidade natural da mente humana. A este tipo de pensamento se atribuem os processos associativos, que procedem de um ponto central ou se encontram com ele. Quando uma unidade de informação chega ao cérebro, muitas conexões são geradas com outros dados disponíveis. Essas relações, produzidas a partir de núcleos que irradiam conexões em várias direções, transformam o cérebro humano em uma "máquina de associações ramificadas" (ONTORIA et al., 2008). Sua grande capacidade de processamento de informação e de aprendizagem possibilita o pensamento irradiante, o qual mantém uma estreita relação com o pensamento criativo, pois todo ato criativo representa uma forma nova de organizar o entorno, ou seja, é produzir, formar, dar origem, representar pela primeira vez.

Para estes estudiosos, os mapas mentais podem ser considerados reflexos gráficos do pensamento irradiante e criativo, sendo ótimos aliados para canalizar a criatividade, pois articulam as habilidades de imaginação, associação de ideias e flexibilidade.

Pelo exposto, o uso do pensamento visual, por meio de representações gráficas, favorece a percepção de conexões simultâneas, imprimindo mais agilidade na compreensão das relações do "sistema projetual" e na associação de informações. As 
facilidades apontadas por Eppler e Burkhard reforçam o valor das ferramentas de síntese que se apoiam no raciocínio visual, sendo essenciais para a assimilação do fluxo de conhecimentos decorrentes do processo projetual. Estas estratégias propiciam um meio eficaz à organização cognitiva para concretizar abstrações, facilitar a síntese de conceitos e estimular os sujeitos envolvidos a coordenar seus domínios de ação sob o mesmo foco.

\subsubsection{FERRAMENTAS DE SÍNTESE VISUAL NO DESIGN DE MODA}

Para adentrar a realidade de múltiplas influências que rege o Design de Moda, é necessário que o estudante mantenha uma postura investigativa, desvendando comportamentos de consumo, códigos de linguagem, possibilidades de materiais e tecnologias. Seivewright (2012) e Mbonu (2014) discorrem sobre os elementos essenciais para a pesquisa criativa do designer de moda, suas contribuições foram agregadas às de Montemezzo (2003), Treptow (2013), Jones (2005), Sorger e Udale (2009) e Rech (2002), sobre o desenvolvimento de produtos de vestuário de moda, extraindo-se pontos de concordância acerca da fase de pesquisa e da gestão de sínteses visuais. Os argumentos corroboram os seguintes pontos: a) indicam a síntese de delimitadores estético-expressivos como ponto crucial no desenvolvimento deste tipo de produto; b) destacam que o conhecimento técnico construtivo e das proporções corpóreas é imprescindível para a experimentação tridimensional da forma, procedimento essencial ao processo de pesquisa para a configuração do vestuário; c) valorizam a pesquisa visual e citam desenhos, cadernos de esboços, painéis imagéticos e mapas mentais (SEIVEWRIGHT, 2012; MBONU, 2014) como ferramentas eficazes para registrar, sintetizar e expressar ideias.

A relevância da experimentação concreta é corroborada por Ostrower (1999). A autora argumenta sobre a importância da materialidade nos processos criativos afirmando que "o pensar só se tornará imaginativo por meio da concretização de uma materialidade, do contrário, não passaria de divagação descompromissada, 'sem rumo e sem finalidade" (OSTROWER, 1999, p.32). Para a autora, a experimentação é imprescindível para evoluir a ordenação da forma. 


\begin{abstract}
Quando se configura algo e se o define, surgem novas alternativas. Essa visão nos permite entender que o processo de criar incorpora um princípio dialético. É um processo contínuo que se regenera por si mesmo e onde o ampliar e o delimitar representam aspectos concomitantes, aspectos que se encontram em oposição e tensa unificação. A cada etapa, o delimitar participa do ampliar. Há um fechamento, uma absorção de circunstâncias anteriores, e, a partir do que anteriormente fora definido e delimitado, se dá uma nova abertura. Da definição que ocorreu, nascem as possibilidades de diversificação. (OSTROWER, 1999, p.26-27).
\end{abstract}

Acerca da pesquisa visual, outro ponto essencial, descrevem-se brevemente as ferramentas que exploram o pensamento visual mais adotado no âmbito educacional do Design de Moda. Entre as estratégias descritas encontram-se algumas bastante utilizadas no design, em geral, e outras destacadas por Seivewright (2012), Jones (2005) e Mbonu (2014) para o projeto na área de moda.

A) Mood Charts ou Mood Board: Bürdek (2006) explica que é uma técnica de colagem (charts) que auxilia a representação do contexto em que está inserido o projeto. Consiste em um painel de imagens baseado nos códigos de linguagem e comportamentos do universo de usuários. Contudo, pode ser empregado em várias etapas do projeto, já que a função é delinear um cenário de referências múltiplas sobre um direcionamento simbólico. Embora alguns autores situem esta ferramenta também como Painel Semântico, no ambiente acadêmico em questão, estas ferramentas se desenvolvem de forma distinta ou complementar, visto que no primeiro há uma profusão de informações, que sugerem múltiplas possibilidades de análises e interpretações e, no segundo, o conceito simbólico já é traduzido em uma referência compositiva de estilo e sintaxe visual.

B) Painel de Estilo de Vida: segundo Baxter (1998) é a reunião de imagens que fazem referência ao perfil e estilo de vida dos usuários, expressando atitudes cotidianas e valores socioculturais. Ilustra situações e referenciais estéticosimbólicos que possam representar os principais valores assimilados pelo grupo de usuários.

C) Painel Semântico: trata-se de uma ferramenta baseada na comunicação por meio de metáforas visuais. Construído, normalmente, por colagem (manual 
ou digital), com recortes de imagens, fotografias ou desenhos. Baxter (1998) o denomina como Painel de Expressão do Produto, pois representa a sensação subjetiva que o produto irá transmitir, gerando a essência de estilo em uma composição sintética e coerente. Um exemplo deste raciocínio de síntese é ilustrado na Figura 11, em que se vê a decodificação da referência samurai em um conceito Kawaii, que em português poderia ser definido como a essência lúdica, bonita, meiga e um pouco infantilizada, encontrada normalmente em um nicho específico de produtos japoneses.

Figura 11 - Exemplo de decodificação de referência estética em um painel semântico

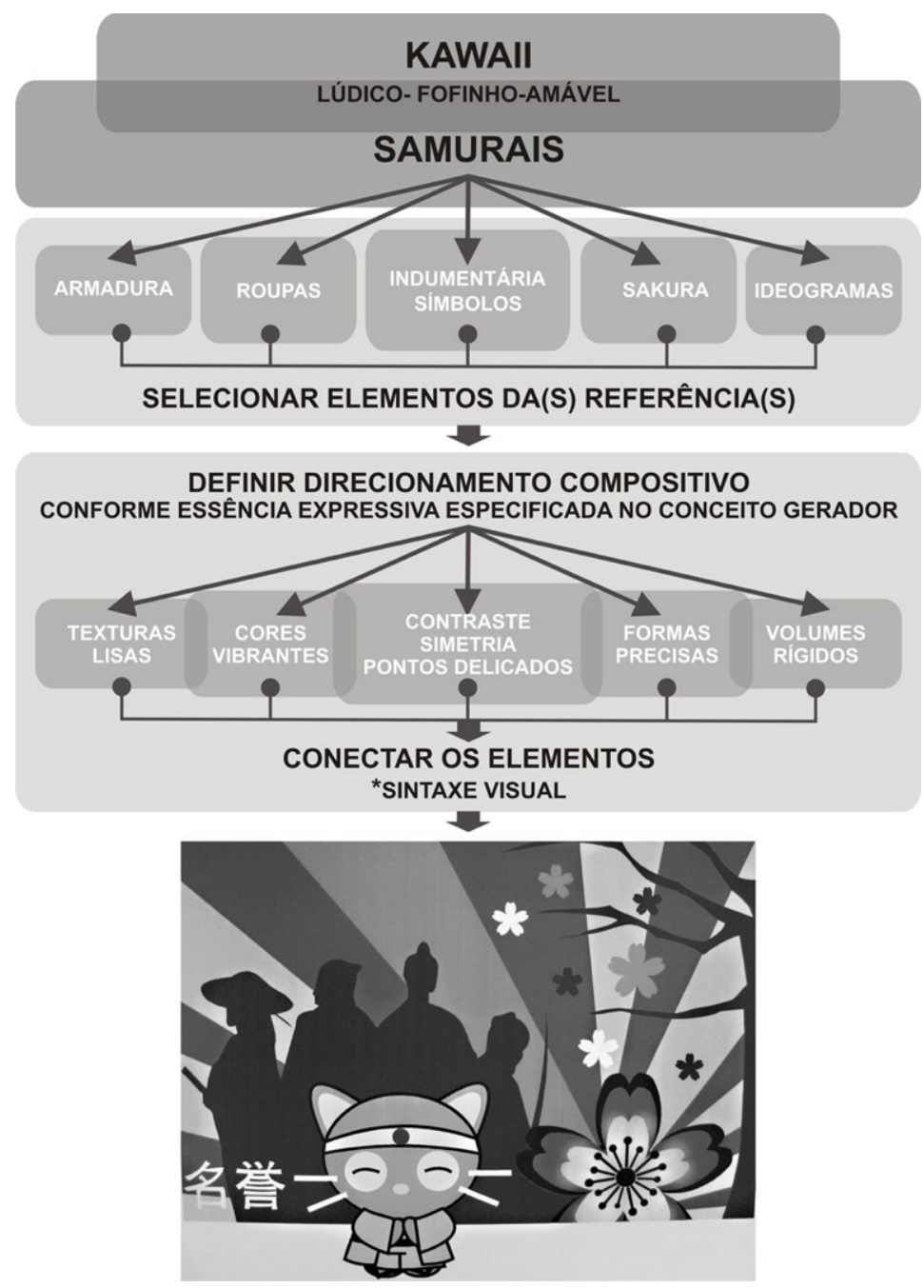

Fonte: Sanches (2012) - Autora do painel semântico: Paula Hatadani

D) Painel de Tema Visual: conforme a definição de Baxter (1998), é um painel que reúne imagens de produtos que compartilhem o mesmo "espírito" 
expressivo pretendido para o artefato projetado. Tais produtos podem ser selecionados de forma diversificada, no que concerne à função ou setor de mercado, auxiliando, assim, a elaboração de uma abordagem de estilo por meio da observação e combinação de formas.

E) Foto-diário (ou diário fotográfico): é uma ferramenta que permite registrar e compreender situações específicas de forma continuada. De acordo com Milton e Rodgers (2013), o foto-diário permite captar detalhes do contexto estudado, por meio de uma sequência de registros fotográficos de uma conduta, comportamento ou ambiente dinâmico. O procedimento promove empatia com o cotidiano do usuário, gerando evidências relacionadas ao contexto de uso ou às experiências subjetivas. No Design de Moda, este recurso pode ser empregado nas pesquisas iniciais de contextualização, durante o trajeto de geração e seleção de ideias, registrando a evolução das experimentações tridimensionais, ou ainda nos testes de usabilidade.

F) Sketchbook: Seivewright (2012) e Mbonu (2014) assinalam que para o designer de moda é essencial recompilar as informações, explorar e experimentar ideias, registrando tais processos em um caderno. Os autores concordam que esses cadernos de registro não são meramente um álbum de recortes e rascunhos, mas um meio gráfico-visual de aprender, sintetizar e processar a informação recolhida. Além de auxiliar a organização da pesquisa criativa, também é uma importante ferramenta de comunicação entre os profissionais envolvidos em um mesmo projeto.

G) Mapa Mental: segundo Buzan e Buzan (1996), esse tipo de ferramenta integra diversas estruturas cognitivas, encadeando o pensamento irradiante, o imaginativo e o estruturado, simultaneamente. Desta forma, promove a irradiação de uma ideia central em uma rede de relações, as quais são impulsionadas por estímulos associados (palavras, imagens, esquemas gráficos, etc.) e sintetizadas em um espaço multidimensional, que facilita uma apreensão totalizante e unificante das informações. Tal ferramenta consiste em uma estrutura gráfica, em que se registram os pontos e ideias centrais de um tema, estabelecendo relações entre eles, por meio da combinação de forma, cores e desenhos (ONTORIA et al., 2008). 
Com a utilização do instrumental supracitado, na trajetória investigativa do processo de design, o pensamento projetual é auxiliado pelo pensamento visual gráfico e pelas experimentações volumétricas entre matéria e corpo, transformando as informações em delimitadores da forma. Para isso, as variáveis do universo do usuário se agregam àquelas relativas ao posicionamento mercadológico e recursos tecnoprodutivos, se convertendo em equacionamentos formais/visuais.

Sobre esta indicativa de integração de canais de expressão e transversalidade de saberes foi determinado o traçado metodológico da pesquisa e sua intervenção em campo, conforme explicado no próximo capítulo. 


\section{CAPÍTULO 4}

Sobre as Conexós

Sobre as Conexões Metodológicas 


\section{METODOLOGIA DA PESQUISA}

A presente pesquisa se caracteriza, segundo a natureza dos dados, como pesquisa qualitativa que, de acordo com Flick (2004), é marcada pela análise de distintas perspectivas, pelas reflexões dos pesquisadores como parte do processo de produção de conhecimento e pela variedade de abordagens e métodos adotados. Em face ao contexto educacional que a circunda, e também aos preceitos teóricos que indicaram o papel ativo do aprendiz na construção do conhecimento e na decisão das abordagens metodológicas, evidencia-se um posicionamento construtivista no que concerne ao quadro referencial para a aprendizagem e a interação em campo.

Não obstante, o traçado metodológico assimilou posturas e procedimentos que se adequassem à natureza interdisciplinar e holística da pesquisa e ao perfil da pesquisadora, evitando posicionamentos rígidos e combinando estratégias.

\subsection{DA PERGUNTA AO TRAÇADO METODOLÓGICO}

O enfoque qualitativo acolheu a essência propositiva do estudo, visto que a meta principal era propor e aplicar estratégias metodológicas à prática projetual dos estudantes. Para tanto, utilizou-se uma plataforma teórico-empírica como meio de coleta e análise de dados, partindo das inferências da revisão de literatura e das análises documentais para adentrar o contexto real. No sentido de operacionalizar tal abordagem, dividiu-se o estudo em três ênfases de procedimentos: procedimentos de diagnóstico; procedimentos de síntese; procedimentos de aplicação e validação.

O núcleo diagnóstico, de base exploratória, centrou-se na delimitação de diretrizes para a abordagem do objeto de pesquisa, sintetizando as bases teóricas apresentadas anteriormente e confirmando as observações preliminares da prática docente, por intermédio de análises documentais dos registros de processo (fichassíntese) e entrevistas (focus group e questionários). O núcleo de síntese se prestou às conexões conceituais que embasaram a proposição das ferramentas de projeto. Por último, o núcleo de aplicação e validação concentrou os procedimentos para as interações em campo, ordenados sobre uma estrutura flexível, a qual permitiu a 
acomodação ao contexto natural e a inserção de novas estratégias, de acordo com a evolução das práticas.

\subsubsection{RECORTE ESPAÇOTEMPORAL}

Ainda que a pesquisa tenha assimilado um largo processo de investigação prévia, em virtude da reflexão sistematizada da prática docente, foi essencial estabelecer um recorte preciso, equacionando o tempo limite de doutoramento e o nível de abrangência para controle da coleta de dados. Neste sentido, a partir da disponibilidade de tempo, amparada pela facilidade de acesso ao campo de estudo e o amplo conhecimento dos aspectos estruturais e históricos do curso em questão, foi definido o recorte espaçotemporal da pesquisa (Figura 12).

Situado no âmbito pedagógico do Bacharelado em Design de Moda da Universidade Estadual de Londrina (UEL), o recorte limitou um período de três anos de interação, focando as práticas projetuais preparatórias, nas quais são realizados projetos de curta duração, com o intuito de experimentar ferramentas de projeto e ampliar a vivência metodológica.

Figura 12 - Recorte da pesquisa

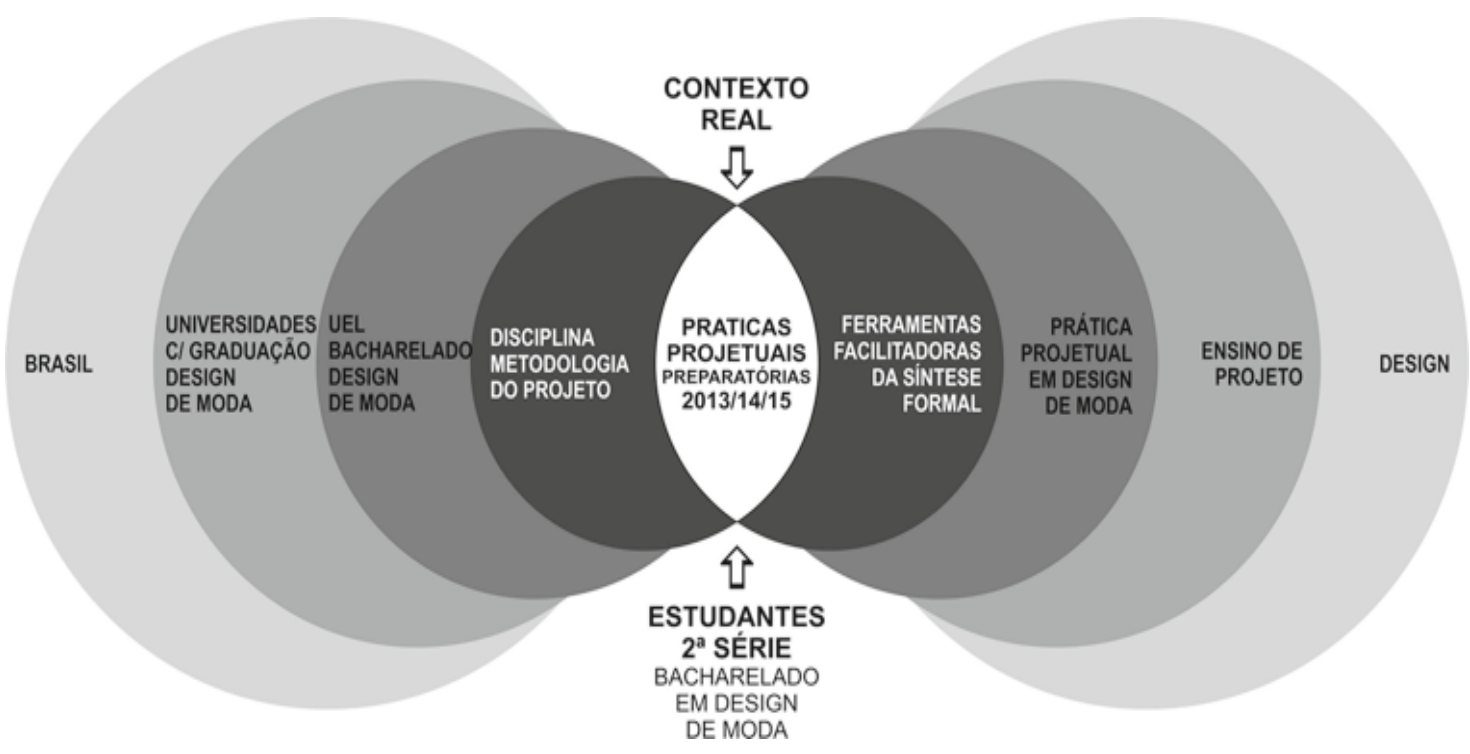

Fonte: elaborado pela autora (2013) 


\subsubsection{METODOLOGIA PARA INTERVENÇÃO EM CAMPO}

Por meio da estratégia da investigação-ação, foi realizada a inserção na realidade estudada, com o propósito de examinar a interação dos estudantes com um novo instrumental para a prática projetual. A inserção em campo assimilou um caráter ativo de observação participante, alternando entre a postura etnográfica, para observar os efeitos concretos gerados, e a intervenção colaborativa, para assimilar novas inferências e melhorar a ação em curso. Destaca-se que a postura etnográfica mencionada não faz referência ao tratamento dos dados, mas apenas ao princípio de que o pesquisador, como observador participante e principal instrumento na coleta de dados, pode responder ativamente às circunstâncias que o cercam, adaptando técnicas de coleta ou revendo diretrizes no decorrer da pesquisa (ANDRÉ, 2005, p.24-25).

Da mesma forma, utiliza-se a expressão investigação-ação como termo amplo, reportando-se as pesquisas, em que "se aprimora a prática pela oscilação sistemática entre agir no campo da prática e investigar a respeito dela" (TRIPP, 2005, p.446). Com a mesma conotação ampla, Zeichner e Pereira (2005) adotam o termo pesquisa-ação, nas esferas da pesquisa educacional, referindo-se à pesquisa sistemática feita por profissionais sobre as suas próprias práticas. Estes autores argumentam que há muita discussão na literatura especializada sobre o que é e o que não é a "verdadeira" pesquisa-ação, sobre os elementos que a constituem, sobre se ela deve ser colaborativa ou não, entre outros nós. Sobre isso, afirmam que o movimento teórico em torno deste tipo de pesquisa é algo bastante dinâmico e heterogêneo e que a pesquisa-ação tem sido implementada de modo diversificado, refletindo diferentes abordagens e concepções sobre o aprendizado dos professores e dos estudantes.

Para esclarecimento, Martins e Theophilo (2009), Tripp (2005) e Thiollent (1996) argumentam que não há unanimidade a respeito das terminologias para denominar as investigações que se propõem a realizar em ações transformadoras no meio pesquisado, a partir de uma interação ativa entre pesquisador e sujeitos participantes. Thiollent (1996) pondera que o papel participativo, exercido pelo pesquisador, tem levado a ambiguidades sobre a distinção entre pesquisa-ação e pesquisa participante. Nesta direção, se posiciona assinalando que toda pesquisa-ação é de tipo participativo: a participação das pessoas implicadas nos problemas investigados é absolutamente 
necessária. Porém, nem toda pesquisa participante é pesquisa-ação, já que pesquisa participante é, em alguns casos, uma investigação baseada na observação participante na qual os pesquisadores estabelecem relações comunicativas com os sujeitos da situação investigada para serem mais bem aceitos, não implicando, necessariamente, ações colaborativas e transformadoras. Apesar de distinguir os dois tipos de pesquisa, Thiollent (1996) enfatiza que não há consenso sobre tal distinção, por isso considera que a participação do pesquisador não qualifica a especificidade da pesquisa-ação, que consiste em organizar a investigação em torno da concepção, do desenrolar e da avaliação de uma ação planejada.

Igualmente, nesta pesquisa foi reconhecido o papel de participação ativa da pesquisadora, bem como o propósito essencial de intervir em um conjunto de práticas adotadas em um contexto específico, visando à reflexão e à transformação de tais práticas. Por conseguinte, adotou-se o termo investigação-ação ${ }^{49}$ para denominar o direcionamento estratégico, tomando como base o ciclo sintetizado por Tripp (2005), para este tipo de estudo (Figura 13), no qual se alternam ciclos de planejamento, ação monitoramento e avaliação de uma mudança para a melhora da prática, aprendendo mais, durante o processo, tanto a respeito da prática, quanto da própria investigação.

Desta perspectiva, o processo investigativo se tornou um processo de aprendizagem para todos os participantes. Martins e Theophilo (2009) ratificam que os aspectos colaborativos podem levar ao aprendizado recíproco e Thiollent (1996, p. 15) reforça que este tipo de pesquisa "não se limita a uma forma de ação (risco de ativismo): pretende-se aumentar o conhecimento dos pesquisadores e o conhecimento ou o "nível de consciência" das pessoas e grupos considerados".

\footnotetext{
49 Tripp (2005) situa a pesquisa-ação entre os diversos desenvolvimentos que adquiriu a investigaçãoação. Pondera o termo historicamente, em que a conotação de pesquisa-ação tomou diversos sentidos em diferentes campos de aplicação, situando a expressão investigação-ação em um nível mais abrangente. Como a intenção aqui é estabelecer a essência da ação em um campo, a qual certamente se vincula aos aspectos amplos destacados pelos autores citados [TRIPP (2005); THIOLLENT (1996); ZEICHNER e PEREIRA (2005)], considerou-se o termo investigação-ação como a opção mais adequada.
} 
Figura 13 - Representação em quatro fases do ciclo básico da investigação-ação

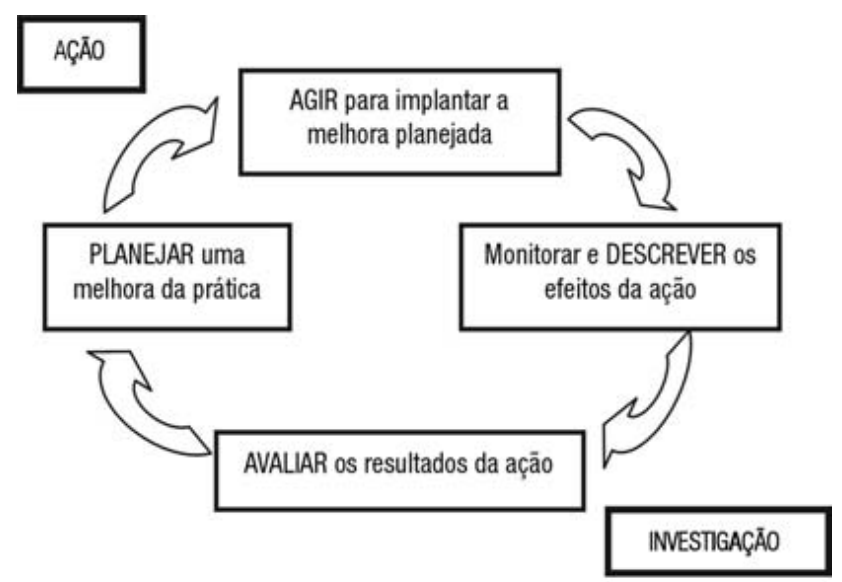

Fonte: Tripp (2005)

Ao assumir que a atuação em campo seria um processo de aprendizado, visando à transformação da prática projetual para os estudantes, mas também a ampliação do conhecimento sobre o raciocínio projetual para a pesquisadora e professores colaboradores envolvidos no processo, se fez a determinação de que as interações em campo devessem propiciar um ambiente colaborativo, mantendo as características naturais do contexto e permitindo que os ciclos de investigação-ação ajudassem na assimilação de novas inferências para melhorar a ação em curso. Por isso, tendo em vista que essa postura presume desdobramentos, conforme realiza a aproximação com o universo pesquisado, os contatos em campo foram empregados em mais de uma etapa da pesquisa de doutoramento, pois as elaborações iniciais das ferramentas identificaram pontos críticos, a partir da observação das condutas espontâneas e das opiniões dos participantes.

Essas premissas guiaram as interações realizadas com os estudantes do Curso de Design de Moda da Universidade Estadual de Londrina (UEL) em oficinas/aulas de projeto para diagnóstico, teste e validação das ferramentas propostas. As oficinas de projeto foram distribuídas em três momentos, com grupos distintos, contando com a colaboração de 77 alunos no total e 8 professores (especialistas em áreas de projeto, modelagem, confecção e tecnologia). As interações foram documentadas por meio de imagens fotográficas, vídeos e protocolos de observação, com registro simultâneo de observações descritivas e reflexivas. O estudo ocorreu do seguinte modo: 
A) INTERAÇÃO 1: aplicação da ferramenta Mapa de Categorias Expressivas, em formato de repentina ( 5 horas).

B) INTERAÇÃO 2: FASE 1: diagnóstico de dificuldades no processo projetual (focus group); FASE 2: pré-teste do Diagrama REC, em formato de oficinas de projeto, com alunos voluntários em atividade extraclasse (30 horas).

C) INTERAÇÃO 3: FASE 1: confirmação de diagnóstico (questionários); FASE 2: teste do Diagrama REC ${ }^{50}$ integrado ao Mapa de Categorias Expressivas em formato de oficinas semanais de projeto, com alunos em atividade curricular regular (90h em campo).

Para auxiliar a objetividade da pesquisa, foram mesclados tratamentos quantitativos à triangulação interna de dados, aportando uma percepção panorâmica das evidências recorrentes. Além disso, as recomendações de Thiollent (1996) sobre a definição precisa de conceitos, estratégias de condução e avaliação foram acatadas. Contudo, o mesmo autor coloca que a investigação-ação contém momentos de raciocínio de tipo inferencial (não limitados às inferências lógicas e estatísticas) e é moldada por processos de argumentação ou de "diálogo" entre vários interlocutores (THIOLLENT, 1996; MARTINS; THEÓPHILO, 2009).

\footnotetext{
Não se trata de chegar a uma formalização lógica nem a um cálculo de proposições ou à manipulação de variáveis simbolicamente representadas, o principal objetivo consiste em oferecer ao pesquisador melhores condições de compreensão, decifração, interpretação, análise e síntese do "material" qualitativo gerado na situação investigativa (THIOLLENT, 1996, p. 28).
}

A título de esclarecimento, a Figura 14 sintetiza a distribuição de técnicas de coleta de informações, dados e evidências no traçado metodológico da pesquisa, a partir dos direcionamentos resumidos anteriormente.

\footnotetext{
50 O Diagrama REC e o Mapa de Categorias Expressivas são ferramentas projetuais que foram propostas a partir das conexões teóricas e evoluíram em campo. Sua elaboração foi detalhada no capítulo 6.
} 
Figura 14 - Panorama de técnicas e procedimentos da pesquisa

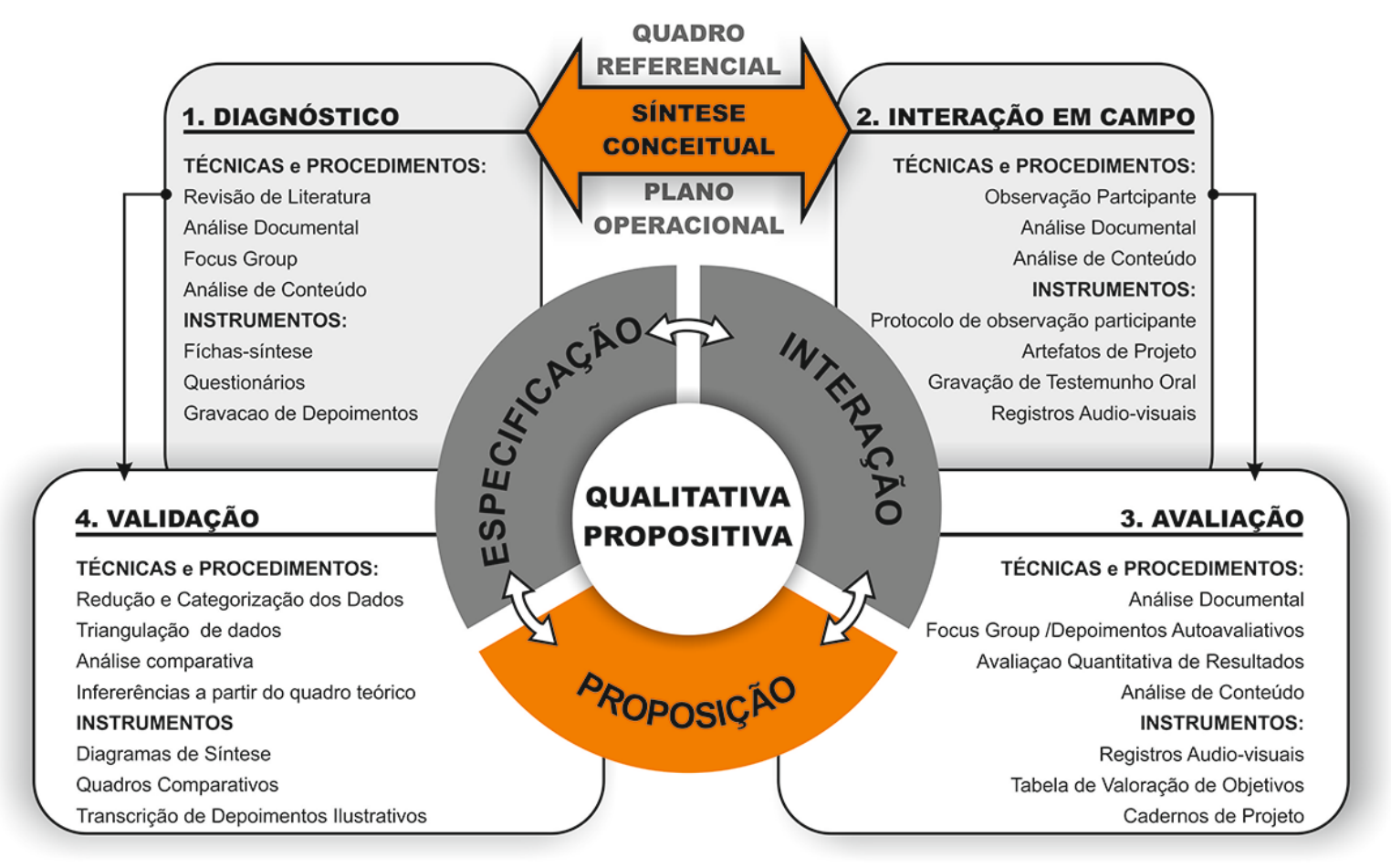

Fonte: elaborado pela autora com base na pesquisa realizada (2014)

O diagrama mostra a ligação entre os núcleos de procedimentos mencionados (diagnóstico; síntese; aplicação/validação) e o ciclo de investigação-ação, na tentativa de demonstrar que, mesmo havendo uma trajetória sequencial, o caminho investigativo originou raciocínios cíclicos e promoveu o ajuste das sínteses efetuadas no transcurso. Assim, o espaço diagnóstico forneceu especificações para sintetizar, conceitualmente, uma proposta de estratégias para as interações em campo que, por sua vez, foi continuamente avaliada, de acordo com as evoluções espontâneas ocorridas em sala de aula, até a proposição final. Esse movimento, obviamente, levou a novas buscas para complementar as especificações e realimentar a proposta.

Como já explicado, algumas estratégias foram definidas com o desenrolar da ação em colaboração com os alunos. Tais condutas serão detalhadas nos tópicos em que se relata cada interação. Igualmente, para planejar as interações, delineou-se um conjunto de estratégias conceituais, derivadas da conexão entre os resultados de diagnóstico e as bases teóricas. Os próximos capítulos foram organizados para dar ao leitor a possibilidade de acompanhar a evolução destas análises específicas e os desdobramentos provenientes dos ciclos da investigação-ação. 


\section{CAPÍTULO 5}

Sobre as Conexões Estratégicas 


\section{CONEXÕES ESTRATÉGICAS}

5 CONEXOESESTRATEICAS

Este capítulo apresenta as delimitações preliminares, resultantes das análises exploratórias do problema de pesquisa. Para isso, foram aglutinadas ao conhecimento prévio do ambiente estudado as bases teóricas e as análises de diagnóstico.

Os resultados registrados a seguir são imprescindíveis para o entendimento da proposição das ferramentas usadas em campo e, principalmente, para esclarecer a assimilação dos desdobramentos surgidos nas interações com os estudantes, haja vista o aspecto colaborativo e cíclico que caracteriza uma investigação-ação. Por isso, para que o leitor acompanhe a linha de raciocínio são apresentados, neste capítulo, os procedimentos de diagnóstico e as aferições conceituais estratégicas que orientaram a intervenção em campo.

\subsection{PROCEDIMENTOS DE DIAGNÓSTICO}

Uma vez que o contexto estudado já era profundamente assimilado pela pesquisadora, o diagnóstico se concentrou em confirmar observações preliminares e identificar pontos específicos relacionados ao problema estudado.

A partir da síntese dos vínculos teóricos, agregados às observações dos anos de prática docente no ambiente estudado, definiu-se a premência de algumas confirmações: a) as ferramentas de síntese visual mais utilizadas nas atividades de projeto; b) dificuldades na delimitação projetual; c) posicionamentos pedagógicos preexistentes para o ensino/aprendizagem de projeto.

Os temas foram averiguados por meio de análises documentais e das opiniões dos sujeitos participantes, combinando técnicas e comparando os dados em evolução cronológica, conforme relatado nos próximos tópicos.

\subsubsection{FERRAMENTAS DE SÍNTESE VISUAL/FORMAL NO UNIVERSO ESTUDADO}

Com o intuito de estudar o uso deste tipo de estratégias no ensino/aprendizagem de projeto, diretamente no universo acadêmico do Design de Moda, a investigação de 
doutoramento tomou a forma de um projeto de pesquisa, denominado Incubadora de Novas Ideias: laboratório de estudo de metodologias para a sintaxe visual, como já citado anteriormente. O projeto dedicou-se a análise de ferramentas metodológicas que facilitassem a sintaxe da linguagem visual no projeto de Design de Moda, por meio da pesquisa aplicada no curso de Design de Moda da UEL. A seguir foram resumidas as contribuições neste sentido.

Analisando os objetivos e os conteúdos curriculares das disciplinas de Metodologia Visual e Composição, que se dedicam a habilitar os alunos para manejar a linguagem visual, os procedimentos didáticos estão centrados na conceituação dos elementos e princípios da linguagem visual, na análise de mensagens não verbais, na construção de imagens e na experimentação da sintaxe visual em produtos de moda.

A partir deste alicerce, as ferramentas de síntese imagética são utilizadas para aprimorar a capacidade de síntese e de expressão. Essas representações se mostram como ótimas aliadas na gestão do processo criativo, auxiliando a abordagem de aspectos estético-simbólicos na experiência de uso do vestuário de moda. Para melhor compreender o percurso desta "educação visual" na formação, o Quadro 5 demonstra o trajeto do desenvolvimento da competência expressiva para a construção e uso de imagens como ferramenta nas práticas projetuais.

Quadro 5 - Percurso do desenvolvimento do raciocínio de composição visual

\begin{tabular}{|c|c|c|}
\hline \multicolumn{2}{|l|}{ Ação } & Habilidade/ Competência \\
\hline \multicolumn{2}{|l|}{ CONHECER } & $\begin{array}{l}\text { Distinguir os elementos e princípios da sintaxe de mensagens } \\
\text { visuais. }\end{array}$ \\
\hline RECONHECER & \multirow{2}{*}{ 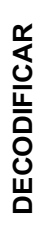 } & $\begin{array}{l}\text { Identificar os elementos constitutivos de uma mensagem visual e } \\
\text { compreender as relações estabelecidas entre eles. }\end{array}$ \\
\hline DECOMPOR & & Extrair os elementos que compõem uma mensagem visual. \\
\hline RELACIONAR & \multirow{2}{*}{$\begin{array}{l}\frac{\alpha}{\mathbb{N}} \\
\frac{\underline{E}}{\mathbf{E}} \\
\frac{\mathbf{W}}{\omega}\end{array}$} & $\begin{array}{l}\text { Definir os elementos visuais e a estrutura dos procedimentos } \\
\text { relacionais para a representação de uma informação. }\end{array}$ \\
\hline COMPOR & & Expressar informação por meio de imagens. \\
\hline \multicolumn{2}{|l|}{ TRANSPOR } & Sintetizar e transportar conceitos visuais para produtos de moda. \\
\hline
\end{tabular}


Cabe enfatizar que o emprego de ferramentas de síntese visual, em especial os painéis imagéticos, já se estabeleceu como um importante auxílio na expressão de códigos semânticos para o universo estudado. Entretanto, Sanches (2008) alerta que no campo profissional da moda, apesar de a pesquisa de imagens já ser algo muito explorado como meio para figurar as correntes estéticas e compilar características formais para os produtos, a sua utilização ainda é muito empírica e, por vezes, pontual e fragmentada. Por isso, foi dada especial atenção a este tipo de estratégia, visando uma organização didática para aproveitar melhor seu potencial nas esferas educacionais. A utilização destas ferramentas pode ser bastante ampla, haja vista que a comunicação por meios não verbais, incluindo desenhos de representação do produto e pesquisas fotográficas, pode ser utilizada em várias fases do projeto. Conforme Sanches (2012), Eppler e Burkhard (2004) e Burdek (2006), o instrumental visual pode ser inserido como meio de organização cognitiva, com o propósito de concretizar abstrações, sintetizar parâmetros ou transferir conhecimento no trabalho em equipe.

Ponderando algumas estratégias que se destinam ao direcionamento sintáticosemântico no universo estudado, distinguem-se dois grupos, segundo seu objetivo no trajeto projetual:

A) Sínteses imagéticas para abstração subjetiva, metáforas visuais que sintetizam um conteúdo simbólico, como painel semântico ou mood board.

B) Experimentação criativa de estruturas sintáticas, centrada principalmente nas pesquisas criativas com a modelagem tridimensional.

Entre as principais ferramentas utilizadas no curso da UEL, destacam-se os painéis de síntese do cenário sociocultural, como o Painel de Estilo de Vida e o Mood Board de Conceito de Marca, assim como os de expressão emocional do produto, como o Painel Semântico. Em relação aos registros gráficos de pesquisa é corriqueiro o uso de sketchbooks e diários fotográficos das experimentações em moulage.

Convém enfatizar que o direcionamento do instrumental metodológico depende de cada situação projetual e das decisões individuais - ou em dinâmicas coletivas - já que a postura que rege o ensino das metodologias de projeto na presente instituição é a flexibilidade da conduta e o estímulo à autonomia.

Contudo, para efeitos didáticos, organizou-se, no Quadro 6, um diagrama de vinculações entre os enfoques das ações de projeto e as aplicações mais recorrentes da 
síntese visual como ferramenta metodológica. O quadro integra o resumo esquemático dos principais tópicos investigados pelos estudantes no transcurso do desenvolvimento de produtos de moda, o foco das ações de projeto e o instrumental visual correspondente.

Quadro 6 - Ferramentas de síntese visual/gráfica na configuração de produtos de vestuário de moda

\begin{tabular}{|c|c|c|c|c|}
\hline Pesquisa & \multicolumn{2}{|c|}{ Foco das Ações } & \multicolumn{2}{|c|}{ Ferramentas } \\
\hline Universo/Usuário & \multirow{3}{*}{ 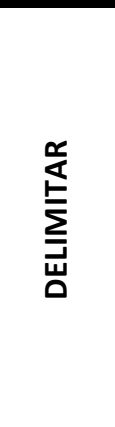 } & \multirow{3}{*}{$\begin{array}{l}\text { Contextualizar } \\
\text { Especificar } \\
\text { Diretrizes }\end{array}$} & \multirow{3}{*}{ 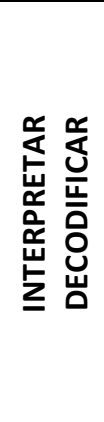 } & \multirow{3}{*}{$\begin{array}{l}\text { Diário Fotográfico } \\
\text { Painel de Estilo de Vida } \\
\text { Mood Board } \\
\text { Painel de Tendências } \\
\text { Painel de Tema Visual } \\
\text { Sketchbook } \\
\text { Vídeo } \\
\text { Mapa Mental }\end{array}$} \\
\hline $\begin{array}{l}\text { Universo/corporativo- } \\
\text { produtivo }\end{array}$ & & & & \\
\hline $\begin{array}{l}\text { Tendências socioculturais } \\
\text { Conteúdo de moda }\end{array}$ & & & & \\
\hline $\begin{array}{l}\text { Diretrizes de utilidade, } \\
\text { adaptação e percepção }\end{array}$ & \multirow{2}{*}{ 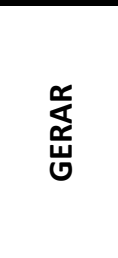 } & \multirow{2}{*}{$\begin{array}{l}\text { Conceituar } \\
\text { Experimentar } \\
\text { possibilidades de } \\
\text { conexão }\end{array}$} & \multirow{2}{*}{ 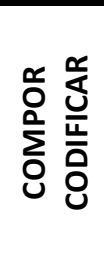 } & \multirow{2}{*}{$\begin{array}{l}\text { Painel Semântico } \\
\text { Registro Fotográfico de } \\
\text { Geração Tridimensional } \\
\text { Esboços e Croquis } \\
\text { Sketchbook }\end{array}$} \\
\hline Conceitos de configuração & & & & \\
\hline Detalhes de Configuração & 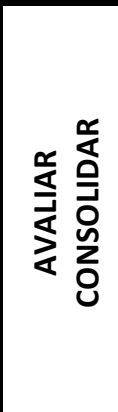 & $\begin{array}{l}\text { Depurar } \\
\text { Avaliar eficácia das } \\
\text { interações, detalhar } \\
\text { e refinar a forma. }\end{array}$ & 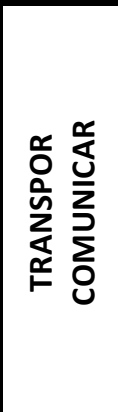 & $\begin{array}{l}\text { Registro fotográfico de } \\
\text { experiências de uso } \\
\text { Plano de Coleção } \\
\text { Desenhos Técnicos } \\
\text { Ilustrações de Moda } \\
\text { Editorial Fotográfico } \\
\text { Dossiê de Coleção } \\
\text { Vídeo }\end{array}$ \\
\hline
\end{tabular}

Fonte: Elaborado pela autora, adaptado de Sanches e Martins (2015)

Entre os recursos enumerados, os painéis imagéticos, o sketchbook e as representações técnicas de produto (desenho técnico, ilustrações, planos e dossiês de coleção) foram assimilados há bastante tempo e fazem parte do cotidiano dos alunos. O hábito de registro fotográfico, tanto de processo como de produto, foi absorvido há menos tempo, mas já é amplamente difundido na documentação de projeto. Já os recursos gráficos de gestão de informação, como o mapa mental, foram introduzidos recentemente e sua aplicação ainda é eventual.

Igualmente, a utilização do vídeo como meio de síntese e expressão é algo novo, porém, pela observação dos resultados e da evolução das experiências com esse veículo, 
torna-se evidente o entusiasmo dos alunos em usá-lo. Os vídeos são aplicados, em especial, para expressar de modo poético o universo do usuário ou para apresentar os resultados do projeto.

Depois de identificadas as principais ferramentas de síntese visual, o próximo passo foi apurar as possíveis deficiências na delimitação projetual, uma vez que o auxílio eficaz deste instrumental depende da clareza e da coerência dos objetivos no planejamento inicial.

\subsubsection{ANÁLISE DOCUMENTAL}

O núcleo diagnóstico da pesquisa contou com análises dos documentos de registro de processo, para verificar as observações sobre deficiências na delimitação projetual. Como a pesquisa já contava com registros preexistentes de observação, em sala de aula, efetuados anteriormente pela presente pesquisadora, esses registros embasaram a escolha das estratégias do estudo, auxiliando o enfoque e a objetividade das análises.

Foram examinados os registros efetuados pelos próprios estudantes, os quais estavam organizados nas Fichas-síntese, um documento usado regularmente no curso para resumir as delimitações do projeto e facilitar a interdisciplinaridade. No conjunto de documentos, o tópico "necessidades a serem atendidas" foi analisado para detectar similaridades de conteúdos, definir as categorias para classificação dos dados e, por fim, identificar os atributos mais apontados como parâmetros projetuais.

No decorrer da classificação das necessidades citadas pelos alunos, percebeu-se que, além da recolha de informações sobre a recorrência de indicadores de falhas, esses registros também poderiam mostrar o nível de abrangência dos atributos que eles consideravam relevantes na experiência de uso. Identificando os delimitadores mais frequentes, foi possível gerar um painel dos níveis de experiência entre vestuário de moda e usuário, a partir da visão dos alunos e das bases teóricas, enfatizando o fluxo de interações ocorrido no sistema usuário - vestuário de moda - ambiente, com vistas a apresentar as condicionantes do processo de configuração do vestuário de moda.

Aproveitando esses dados, em associação com as vertentes teóricas da ergonomia citadas na revisão de literatura, delimitou-se os indicadores de classificação. 
Depois de uma primeira exploração dos dados coletados, foi decidido que as informações extraídas dos documentos deveriam explicitar o estreitamento das vinculações entre usuário e vestuário de moda. Em consequência, optou-se por uma classificação que partisse dos laços tangíveis até chegar aos vínculos intangíveis. Em vista disso, a denominação dos indicadores (funcionalidade, usabilidade e prazer) emprestou vocábulos habituais do campo da ergonomia (MONT'ALVÃO, 2008), mesmo concordando com Löbach $(2001)^{51}$ sobre as facetas que o termo função assume nas esferas do design.

Após a fixação dos indicadores de classificação, o estudo documental examinou as fichas-síntese recolhidas na Disciplina de Metodologia de Projeto, no Curso de Design de Moda da Universidade Estadual de Londrina, arquivadas no acervo da presente pesquisadora. Foram analisados os registros de 55 alunos, nas atividades do projeto integrador na segunda série, dos anos de 2011 e 2012, totalizando 55 documentos. Com base nos indicadores, analisou-se o tópico "necessidades a serem atendidas" nas fichassíntese. Isso possibilitou a classificação dos registros, a identificação dos atributos mais apontados como parâmetros projetuais e suas eventuais deficiências. Para esclarecer, os requisitos de classificação foram assim distribuídos:

A) Funcionalidade: relativo aos quesitos físicos do artefato e função prática, incluindo aqui enunciados sobre materiais (considerando segurança como propriedade intrínseca ao material) e a utilidade básica de cobrir o corpo (incluindo segurança como proteção corporal).

B) Usabilidade: referente aos quesitos que consideram o artefato em exploração sensória, como conforto físico e manejo.

C) Prazer: relativo aos quesitos de linguagem e representações estético-simbólicas, agrupando os enunciados que citavam diretrizes de identificação, emoção e representação social.

Para a percepção da conexão entre os parâmetros elencados e os indicadores ergonômicos, os principais requisitos foram classificados e organizados no Quadro 7.

\footnotetext{
${ }^{51}$ A classificação do autor foi comentada no capítulo 2. Analisa que um produto integra funções práticas, estéticas e simbólicas. O uso da expressão funcionalidade (pendendo ao extremo da função prática) nos indicadores foi considerado o mais adequado para o propósito de constituir uma categoria que incluísse aspectos de utilidade prática e materiais, uma vez a ideia era apresentar a experiência do nível tangível ao intangível. Mais tarde, notou-se que "operacionalidade prática" talvez cumprisse o mesmo papel.
} 
Quadro 7 - Níveis de interação na experiência de uso do vestuário de moda

\begin{tabular}{|c|c|c|}
\hline PARÂMETROS ELENCADOS & CATEGORIA DE EXPERIÊNCIA & INDICADORES \\
\hline $\begin{array}{l}\text { Segurança (propriedades físico- } \\
\text { químicas dos materiais e acessórios) }\end{array}$ & \multirow{3}{*}{$\begin{array}{l}\text { EXPERIÊNCIA EXTRA- } \\
\text { CORPORAL }\end{array}$} & \multirow{4}{*}{ FUNCIONALIDADE } \\
\hline Peso e Resistência (materiais) & & \\
\hline Facilidade de Manutenção & & \\
\hline Proteção Corporal (segurança) & \multirow{4}{*}{$\begin{array}{c}\text { EXPERIÊNCIA SENSÓRIA } \\
\text { Adaptação física } \\
\text { Vestibilidade }\end{array}$} & \\
\hline Liberdade de Movimentos & & \multirow{5}{*}{ USABILIDADE } \\
\hline Conforto Tátil & & \\
\hline Conforto Térmico & & \\
\hline Facilidade de Manuseio & \multirow{6}{*}{$\begin{array}{c}\text { EXPERIÊNCIA COGNITIVA } \\
\text { Expressão Individual } \\
\text { Representação Social }\end{array}$} & \\
\hline Praticidade & & \\
\hline Versatilidade & & \multirow{4}{*}{ PRAZER } \\
\hline$\overline{\text { Atratividade }}$ & & \\
\hline Identificação pessoal/social & & \\
\hline Simbolismo & & \\
\hline
\end{tabular}

Fonte: Sanches et al. (2015)

O quadro sugere que a experiência com o artefato se estende pelos quatro níveis de prazeres, apontados pela classificação de Jordan (2000), e confirmam que os atributos requeridos como parâmetros de projeto se concentram em gerar experiências cognitivas. Vale destacar que a classificação tem o propósito apenas de evidenciar a importância da experiência subjetiva e não deve indicar um entendimento equivocado de que se considera a experiência sensória isolada da cognitiva.

A análise dos documentos de delimitação projetual (fichas-síntese) demonstrou que o planejamento do projeto inclui objetivos que se distribuem em quesitos de adaptação física, expressão individual e, principalmente, representação social. Ressaltando que, embora a relevância do fator intangível seja marcante e, por vezes, o foco principal do projeto, os parâmetros de segurança e conforto, embora frequentemente de modo genérico, foram citados em todos os documentos. Este ponto levou a deduzir que os princípios ergonômicos essenciais foram considerados obrigatórios no planejamento das necessidades a serem atendidas, tendo em vista a interação física direta e generalizada que o vestuário estabelece com o corpo do usuário. Igualmente, a citação de parâmetros relativos à manutenção e materiais, ainda que também genéricos, exprime a preocupação com o artefato em situações anteriores e posteriores ao uso. 
Os parâmetros elencados nas fichas-síntese foram ordenados para demonstrar o fluxo de experiências que podem estimular, revelando que os objetivos enumerados estão estreitamente ligados àqueles vinculados ao de prazer. A constatação corrobora que as experiências sensórias têm papel relevante no intercâmbio de experiências cognitivas entre o universo pessoal e o coletivo. Assim, os aspectos estético-simbólicos são primordiais no projeto de Design de Moda, uma vez que a qualidade estética do artefato está associada à captação sensória, atuando diretamente sobre as significações e prazer que podem emanar do seu uso.

Cabe reforçar que, no caso do vestuário, o uso está vinculado à adaptação do corpo ao entorno, atribuindo-Ihe proteção e, especialmente, uma aparência propícia para aceitação e integração no contexto sociocultural. Logo, o vestuário de moda sempre traz intrínseco um papel afetivo, um propósito de uso social, para o qual a experiência sensória é o veículo. Por isso, ao planejar esta interface, é premente levar em conta que a experiência de uso fusiona percepções em nível físico, psicológico e social, abrangendo espaço privado e público.

Esta experiência de vínculos estreitos torna essencial que as ações de projeto sejam orientadas pela consciência de que as superfícies, os volumes, as cores e as texturas são, concomitantemente, matéria e informação.

Assim, ao congregar a análise da experiência de uso da vestimenta com a verificação dos quesitos que já faziam parte das preocupações dos alunos naquele ponto do percurso formativo, foi confirmado o pressuposto de que o uso de ferramentas facilitadoras da sintaxe formal, ainda que retratem uma síntese de códigos de linguagem estético-visuais, devem partir da percepção conjunta dos espaços do corpo (físico e psíquico) e do entorno (material e cultural).

Por outro lado, a identificação dos níveis de experiência foi útil para aclarar o tipo de resposta que se deve esperar do projeto de Design de Moda, revelando as funções que o vestuário de moda pode assumir no cotidiano humano. Logo, ao corroborar as finalidades de adaptação física, expressão pessoal e representação social do vestuário de moda, se revelaram as classes de informações que podem auxiliar a construção dessas respostas, as quais se darão por meio da forma projetada.

Em relação às carências percebidas nas observações preliminares da pesquisadora, verificou-se que os quesitos de conforto eram citados de modo genérico, 
com pouco aprofundamento no problema projetual específico. Liberdade de movimento e conforto, por exemplo, eram citados praticamente por todos os alunos, mas muitos não especificavam que requisitos específicos de conforto eram importantes na experiência de uso em estudo. Isso demonstrou uma aparente falta de reflexão sobre como tais quesitos influenciavam as decisões iniciais do projeto, o que seria um indicador de falta de integração nas análises de delimitação projetual. Para averiguação, foi imprescindível ouvir a opinião dos estudantes sobre as próprias dificuldades.

\subsubsection{OPINIÃO DOS SUJEITOS PARTICIPANTES}

Uma vez que o recorte da pesquisa foi situado nas práticas projetuais preparatórias da segunda série, quando são apresentadas diversas ferramentas de projeto para ampliar a vivência metodológica, a seleção dos grupos que prestaram depoimentos priorizou os estudantes desta série. Porém, a primeira coleta de depoimentos agregou também um grupo de terceira série, para perceber se as opiniões dos alunos com maior experiência projetual eram semelhantes.

Os sujeitos participantes foram interrogados por meio de focus group e questionários. Tendo em vista que os alunos de cada série tinham uma vivência projetual homogênea, definiu-se que para o focus group os participantes deveriam ser alunos voluntários, já que esta técnica depende de tempo, disposição e não é recomendada para grupos muito grandes. Em contrapartida, os questionários foram aplicados com o grupo total da segunda série de 2015, já que a intenção era averiguar os pontos enumerados no focus group e ter um panorama quantitativo para um perfil geral. Sob estes parâmetros, apresenta-se a síntese dos procedimentos.

\section{A) FOCUS GROUP COM ESTUDANTES DE SEGUNDA E TERCEIRA SÉRIE (2014)}

De acordo com Theóphilo e Martins (2009), o Focus Group consiste em um tipo de entrevista em profundidade, realizada em grupo e que visa à abordagem de um tópico específico. Nesta dinâmica, os participantes influenciam uns aos outros e as ideias compartilhadas proporcionam riqueza e flexibilidade na coleta de informações, tendo em vista que, da integração espontânea das opiniões, estimuladas por um 
moderador, podem derivar novos pontos de vista e aprofundamentos inovadores no assunto tratado. Os autores apontam esta técnica como um bom meio de conhecer as percepções dos sujeitos participantes de uma pesquisa, antes de uma observação participante, pois pode indicar situações alternativas a serem observadas e fornecer elementos para o refinamento dos conceitos e do entendimento sobre o tema investigado.

A intenção implícita no uso deste procedimento foi confirmar os pontos de dificuldade, a partir da visão dos próprios alunos, e também ratificar os indicadores para a observação participante, quando da aplicação das ferramentas.

Com base nestas orientações foram efetuadas duas sessões de focus group, de duas horas cada uma, moderadas pela presente pesquisadora, com dois grupos de alunos: a) terceira série - 10 (dez) alunos que já haviam concluído a disciplina de Metodologia Projetual e passado por dois projetos integradores; b) segunda série - 8 (oito) alunas da 2a série que haviam vivenciado o primeiro bimestre da disciplina de Metodologia Projetual e passado por um projeto integrador.

O procedimento foi efetuado com os alunos voluntários que participaram da segunda interação em campo, em 2014, para aplicação teste do Diagrama REC. A discussão foi gravada em áudio e realizada antes do início da prática com a ferramenta.

Os temas impulsionadores do focus group tomaram como apoio as observações das dificuldades observadas pela pesquisadora em prática docente e a indicativa de deficiências na delimitação projetual. Por conseguinte, as indagações definidas para guiar a moderação foram: a) Como você começa o projeto? Qual o primeiro passo? b) Como identifica um problema de design? Como define os objetivos do projeto? Como delimita as suas ações? c) Existe dificuldade durante o processo projetual? d) Como escolhe a melhor alternativa de solução?

\section{B) SÍNTESE DAS ANÁLISES DOS RESULTADOS DO FOCUS GROUP COM ALUNOS}

A análise dos dados foi realizada de acordo com as recomendações de Martins e Theóphilo (2009) para técnica de análise de conteúdo, cumprindo três procedimentos: pré-análise; descrição analítica; interpretação inferencial em função dos propósitos do estudo, apoiados pelas bases teóricas. Assim, após sucessivas leituras dos depoimentos, foi possível identificar, dentro dos desdobramentos de cada questão, categorias de 
análises a partir dos próprios dados. As categorias constituíram os temas descritores, que propiciaram a classificação e interpretação das informações, segundo seu contexto de conteúdo e aproximação com as sínteses de diagnóstico e da plataforma teórica.

Quadro 8 - Análise focus group - Grupo 1 (3a série)

\begin{tabular}{|c|c|c|}
\hline Diretriz de Moderação & Desdobramentos & Pontos Destacados \\
\hline $\begin{array}{l}\text { Como você começa o } \\
\text { projeto? Por onde? }\end{array}$ & $\begin{array}{l}\text { Pesquisa: (referencias } \\
\text { estéticas-imagéticas/ público- } \\
\text { contexto social)-* sequencia } \\
\text { depende do projeto } \\
{ }^{*} \text { Destrinchar a proposta }\end{array}$ & $\begin{array}{l}\text { Conhecem a importância da } \\
\text { pesquisa, os fatores importantes, } \\
\text { identificam conexões e } \\
\text { desmembramentos, mas citam a } \\
\text { dificuldade de descartar } \\
\text { informações. *(DELIMITAR) }\end{array}$ \\
\hline $\begin{array}{l}\text { Como percebe um } \\
\text { problema de design? } \\
\text { Como delimita? }\end{array}$ & $\begin{array}{l}\text { Identificando uma } \\
\text { Necessidade: com a } \\
\text { pesquisa o problema muda e } \\
\text { se percebem problemas } \\
\text { menores- * conotação } \\
\text { negativa ainda presente/ } \\
\text { *resumir em uma pergunta } \\
\text { muito específica }\end{array}$ & $\begin{array}{l}\text { Citam a evolução da delimitação no } \\
\text { decorrer do processo, mas } \\
\text { consideram que conduta didática de } \\
\text { prazos e cumprimentos de etapas } \\
\text { não permitem essa evolução com } \\
\text { naturalidade }\end{array}$ \\
\hline $\begin{array}{l}\text { Qual a maior } \\
\text { dificuldade durante o } \\
\text { processo projetual? }\end{array}$ & $\begin{array}{l}\text { Organizar (em sequencia } \\
\text { linear) } \\
\text { Sintetizar (escolher o que é } \\
\text { importante) } \\
\text { Gerir (gosto pessoal/ ajustes } \\
\text { como processo orgânico e de } \\
\text { evolução)- rigidez na cobrança } \\
\text { Transpor } \\
\text { Painel semântico pode limitar. } \\
\text { O que levar para o produto? } \\
\text { Como juntar todos os } \\
\text { delimitadores? }\end{array}$ & $\begin{array}{l}\text { Equacionar as variáveis de do } \\
\text { projeto, gerenciando a evolução do } \\
\text { processo, causa ansiedade. } \\
\text { *(DELIMITAR) } \\
\text { Reconhecem a importância da } \\
\text { imagem, mas alguns destacam a } \\
\text { dificuldade em aproveita-la para } \\
\text { transpor conceitos na materialização } \\
\text { do produto. } \\
\text { *(GERAR) }\end{array}$ \\
\hline $\begin{array}{l}\text { Como escolhe a melhor } \\
\text { alternativa de solução? }\end{array}$ & $\begin{array}{l}\text { Delimitação (o que atende } \\
\text { melhor)/ * O apelo estético se } \\
\text { sobrepõe }\end{array}$ & $\begin{array}{l}\text { Concordam que ter uma delimitação } \\
\text { ajuda a estabelecer critérios de } \\
\text { escolha. *(DELIMITAR/ AVALIAR) } \\
\text { Reconhecem que há um ciclo de } \\
\text { geração e seleção que se repete e se } \\
\text { encadeia várias vezes *(GERAR/ } \\
\text { AVALIAR: experimentar/depurar) } \\
\text { Destacam que o apelo estético se } \\
\text { sobrepõe e, frequentemente, é difícil } \\
\text { se desvencilhar de uma ideia } \\
\text { preconcebida. }\end{array}$ \\
\hline
\end{tabular}

Fonte: elaborado pela autora com base na pesquisa realizada (2014)

Para auxiliar a síntese das análises, apresentadas no Quadro 8 e no Quadro 9, se aplicou um procedimento de organização e codificação que partiu das perguntas diretrizes, reunindo os desdobramentos relacionados a cada tema descritor (em 
negrito). Os desdobramentos foram interpretados de acordo com as bases teóricas e destacados os pontos observados, segundo os focos projetuais do Design de Moda, apontados por Sanches (2011), a lembrar: contextualizar/sintetizar parâmetros projetuais; experimentar possibilidades de conexões entre os parâmetros; avaliar a eficácia das conexões e depurá-las; consolidar.

Contudo, ao adentrar as sínteses estratégicas, relatadas mais à frente, as conexões percebidas retroalimentaram os quadros de resultados. Deste modo, constatou-se que os dados poderiam ser agrupados nas categorias de ações projetuais resumidas em delimitar, gerar e avaliar.

Quadro 9 - Análise focus group - Grupo 2 (2ª série)

\begin{tabular}{|c|c|c|}
\hline Diretriz de Moderação & Desdobramentos & Pontos Destacados \\
\hline $\begin{array}{l}\text { Como você começa o } \\
\text { projeto? Por onde? }\end{array}$ & $\begin{array}{l}\text { Público-alvo: } \\
\text { Contexto: *(identificar- } \\
\text { necessidades, dificuldades, } \\
\text { problemas humanos) } \\
\text { *A pesquisa se limita de } \\
\text { acordo com o problema, no } \\
\text { decorrer da investigação. }\end{array}$ & $\begin{array}{l}\text { Conhecem a importância da } \\
\text { pesquisa, os fatores importantes, } \\
\text { identificam conexões e } \\
\text { desmembramentos mas citam a } \\
\text { dificuldade de descartar } \\
\text { informações. *(DELIMITAR) }\end{array}$ \\
\hline $\begin{array}{l}\text { Como percebe um } \\
\text { problema de design? } \\
\text { Como delimita? }\end{array}$ & $\begin{array}{l}\text { Identificando uma } \\
\text { Necessidade: com a } \\
\text { pesquisa o problema muda e } \\
\text { se percebem problemas } \\
\text { menores- Como filtrar as } \\
\text { informações? }\end{array}$ & $\begin{array}{l}\text { Citam com naturalidade a evolução } \\
\text { da delimitação. } \\
\text { *(DELIMITAR/depurar) } \\
\text { Consideram importante o foco e a } \\
\text { síntese de objetivos. *(DELIMITAR) }\end{array}$ \\
\hline $\begin{array}{l}\text { Qual a maior dificuldade } \\
\text { durante o processo } \\
\text { projetual? }\end{array}$ & $\begin{array}{l}\text { Sintetizar (escolher o que é } \\
\text { importante) } \\
\text { Gerir (como atender a todos } \\
\text { os objetivos?) * Relembrar os } \\
\text { objetivos em visão panorâmica } \\
\text { e interligada/ citaram tabela } \\
\text { de seleção por critérios) } \\
\text { Transpor } \\
\text { Iniciar a geração - Painel } \\
\text { semântico ajuda, mas falta } \\
\text { clareza de que simbolismo } \\
\text { expressar e como extrair a } \\
\text { linguagem desta ferramenta. } \\
\text { Como conectar todos os } \\
\text { delimitadores? }\end{array}$ & $\begin{array}{l}\text { Equacionar as variáveis do projeto, } \\
\text { gerenciando a evolução do processo, } \\
\text { causa ansiedade. *(DELIMITAR) } \\
\text { Reconhecem a importância da } \\
\text { imagem, mas alguns destacam a } \\
\text { dificuldade em aproveitá-la para } \\
\text { transpor conceitos na } \\
\text { materialização do produto. } \\
\text { *(GERAR) }\end{array}$ \\
\hline $\begin{array}{l}\text { Como escolhe a melhor } \\
\text { alternativa de solução? }\end{array}$ & Delimitação & $\begin{array}{l}\text { Concordam que ter uma delimitação } \\
\text { ajuda a estabelecer critérios de } \\
\text { escolha. *(DELIMITAR) } \\
\text { Reconhecem que é difícil se } \\
\text { desvencilhar de uma ideia } \\
\text { preconcebida ou do desejo de } \\
\text { inovação radical. }\end{array}$ \\
\hline
\end{tabular}


As dificuldades apontadas pelos alunos da terceira série são muito semelhantes às dos alunos da segunda série, mesmo depois de já haverem passado pela disciplina de Metodologia do Projeto. No entanto, vale assinalar que o grupo da segunda série demonstrou uma postura mais investigativa e citou mais vezes expressões que se referiam a uma pesquisa contínua no decorrer do processo projetual. Este fato pode se relacionar às primeiras iniciativas de aprendizagem significativa assimiladas pela professora que ministrava a disciplina de Metodologia do Projeto no ano de 2014.

As análises revelaram como principais pontos de dificuldade: a) selecionar e organizar as informações pesquisadas; b) transpor as informações para a síntese de objetivos; c) transpor as sínteses imagéticas para a configuração tridimensional dos produtos; d) selecionar a melhor ideia; e) desvencilhar-se de uma ideia preconcebida; f) integrar os objetivos na materialização do projeto.

Sobre estes pontos foi elaborado o próximo procedimento de diagnóstico, o qual também se prestou a detectar a opinião dos alunos, agora com o intuito de confirmar a recorrência dos mesmos pontos em outro grupo na mesma etapa do percurso formativo, no ano letivo seguinte (2aㅡ série- 2015).

\section{C) QUESTIONÁRIOS COM ESTUDANTES DA SEGUNDA SÉRIE (2015)}

Os questionários foram respondidos por $90 \%$ dos estudantes da 2 a série, do ano letivo de 2015, antes do início da atividade projetual para interação com o Diagrama REC em coordenação com o Mapa de Categorias Expressivas.

Com base nos resultados do focus group de 2014, foram elaborados dois questionários para aplicação com o grupo de 2015, visando à averiguação dos pontos críticos apontados pelo primeiro grupo de alunos. O primeiro questionário continha duas perguntas subjetivas abertas e duas fechadas dicotômicas. O segundo questionário consistia em uma pergunta fechada de múltipla escolha, com uma alternativa aberta para inserção de algum ponto não contemplado.

O primeiro instrumento se destinava a identificar a opinião dos participantes sobre as principais ações que compõem o projeto de Design de Moda e, também, a existência de alguma preconcepção sobre uma organização geral para tais ações. 0 segundo, aplicado em seguida, solicitava que os estudantes enumerassem as três maiores dificuldades pessoais em relação ao processo projetual. 
Ressalta-se que os questionários foram aplicados separadamente, para que os tópicos citados nas alternativas do segundo questionário não influenciassem a especificação das ações projetuais solicitadas no primeiro.

\section{D) ANÁLISE DE CONTEÚDO DO QUESTIONÁRIO 1}

A partir dos parâmetros mencionados no tópico anterior, as respostas obtidas foram submetidas à técnica de análise de conteúdo. Nesta técnica, o princípio é desmontar a estrutura de um conteúdo para esclarecer as diferentes características e extrair suas significações. Laville e Dionne (1999) ressaltam que, na análise de conteúdo, "as preocupações quantificadoras tornam-se, às vezes, exclusivas [...]" (LAVILLE; DIONNE 1999, p. 225), visto que as distribuições de frequência podem estimular uma busca por precisão e perder nuances descritivas dos contextos de sentido. Em vista disto, o tratamento quantitativo, por meio da distribuição de frequência, apenas indicou a importância de certos conteúdos, no entanto a análise qualitativa dos resultados se deteve às interações entre os contextos de sentido detectados.

Quadro 10 - Resultados da análise de conteúdo - principais ações projetuais

\begin{tabular}{|c|c|c|c|}
\hline $\begin{array}{l}\text { CATEGORIAS DE AÇÕES } \\
\text { CITADAS }\end{array}$ & $\begin{array}{c}\text { № de } \\
\text { ocorrências }\end{array}$ & CONTEXTO DE SIGNIFICAÇÃO & FOCO PROJETUAL \\
\hline Coletar informações & \multirow{3}{*}{24} & \multirow{3}{*}{ Pesquisa/ coleta de dados } & \multirow{8}{*}{$\begin{array}{l}\text { DELIMITAR: } \\
\text { contextualizar/formular }\end{array}$} \\
\hline Levantar dados & & & \\
\hline Conhecer sobre & & & \\
\hline Selecionar & \multirow{5}{*}{18} & \multirow{5}{*}{$\begin{array}{l}\text { Pesquisa/ análise e seleção de } \\
\text { informações }\end{array}$} & \\
\hline $\begin{array}{l}\text { Mapear um universo de } \\
\text { dados }\end{array}$ & & & \\
\hline Entender & & & \\
\hline Identificar & & & \\
\hline Analisar & & & \\
\hline Definir & \multirow{3}{*}{10} & \multirow{3}{*}{$\begin{array}{l}\text { Pesquisa/direcionar foco } \\
\text { definir o problema de design } \\
\text { (objetivos) }\end{array}$} & \multirow{3}{*}{$\begin{array}{l}\text { DELIMITAR: } \\
\text { formular/conceituar }\end{array}$} \\
\hline Sintetizar & & & \\
\hline Estruturar & & & \\
\hline Gerar ideias & \multirow{2}{*}{24} & \multirow{2}{*}{$\begin{array}{l}\text { Geração de alternativas de } \\
\text { soluções }\end{array}$} & \multirow{2}{*}{$\begin{array}{l}\text { GERAR: experimentar/ } \\
\text { representar/movimentar-se }\end{array}$} \\
\hline Criar & & & \\
\hline Escolher & \multirow[b]{2}{*}{19} & \multirow{2}{*}{ Seleção da melhor solução } & \multirow{2}{*}{$\begin{array}{l}\text { AVALIAR: } \\
\text { refletir/decidir }\end{array}$} \\
\hline Selecionar & & & \\
\hline Prototipar para testar & \multirow{3}{*}{10} & \multirow{3}{*}{$\begin{array}{l}\text { Experimentação para evolução } \\
\text { da proposta }\end{array}$} & \multirow{3}{*}{$\begin{array}{l}\text { GERAR/AVALIAR: } \\
\text { experimentar/depurar } \\
\text { refletir/decidir }\end{array}$} \\
\hline Avaliar para melhorar & & & \\
\hline Testar & & & \\
\hline Modelar & \multirow{3}{*}{12} & \multirow{3}{*}{ Materialização produtiva } & \multirow{3}{*}{$\begin{array}{l}\text { CONSOLIDAR: } \\
\text { depurar/consolidar } \\
\text { implementar }\end{array}$} \\
\hline Prototipar & & & \\
\hline Executar & & & \\
\hline Verificar & 3 & Verificação de eficácia & AVALIAR: refletir/decidir \\
\hline
\end{tabular}

Fonte: elaborado pela autora com base na pesquisa realizada (2014) 
$\mathrm{Na}$ primeira análise geral das respostas, percebeu-se que a maioria dos respondentes usou tópicos curtos e objetivos, sem preocupações com a estrutura formal do texto. Por isso, o recorte dos conteúdos (unidades de análise) foi delimitado em palavras-chave ou expressões, nas quais se poderia identificar o contexto de significação atribuído pelo aluno, traduzindo as ideias conectadas às ações do processo projetual ou à sua organização. Essas unidades de análise foram classificadas por contextos de significação, e a sua ocorrência nos documentos foi registrada para detectar a importância atribuída a determinados fatores (Quadro 10).

Vale ressaltar que a importância de uma pesquisa para a delimitação projetual foi bastante mencionada, contudo a incidência de colocações acerca de um momento para definição de objetivos ou síntese dos dados coletados foi bem menor. A constatação aponta a relevância designada à coleta de informações, porém, ainda que apareçam menções à seleção de informações, os contextos de significação não apontaram clareza sobre o momento de convergir informações em objetivos.

As fases de geração e seleção de ideias foram bastante elencadas e a necessidade de momentos de interações com a materialidade do artefato projetado foi considerada como parte do processo projetual e muito relevante, se considerado o número de ocorrências a este respeito.

Figura 15 - Sobre a existência de uma sequência para as ações elencadas

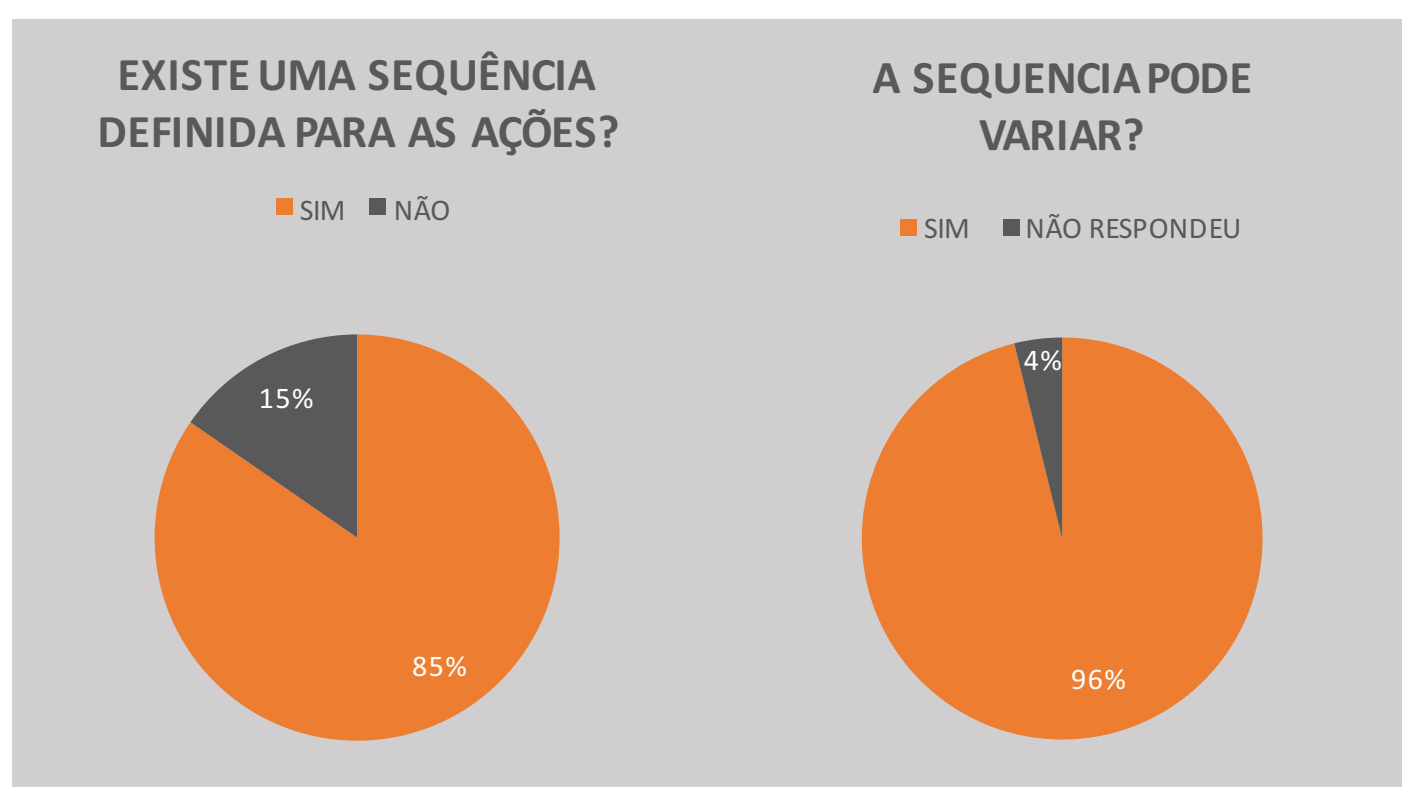

Fonte: Elaborado pela autora com base na pesquisa realizada (2014) 
Sobre a existência de uma sequência preestabelecida dos procedimentos projetuais, observa-se que os alunos participantes têm uma acepção flexível do trajeto projetual, como ilustrado na Figura 15.

Entre os que confirmaram a existência de uma sequência predefinida, observouse a enumeração de um trajeto básico recorrente, em que se destacam: fase de coleta e análise de informações; fase de geração e seleção de ideias; fase de concretização da solução proposta. Este percurso se aproxima muito da organização didática do projeto integrador, já vivenciado pelo grupo de respondentes na série anterior. Entretanto, o alto percentual de respostas positivas sobre uma sequência variável foi um dado muito importante, já que demostrava que, apesar da organização didática em relação ao processo geral do projeto integrador $(\mathrm{PI})$, os estudantes pareciam entender que ela não representava um trajeto hegemônico e seu emprego se destinava ao gerenciamento do tempo e das interações, em conformidade ao calendário institucional.

\section{E) ANÁLISE DOS RESULTADOS DO QUESTIONÁRIO 2}

Antes de aplicar o questionário, foi perguntado aos estudantes se sentiam alguma dificuldade no decorrer do processo projetual. Depois da resposta afirmativa unânime, procedeu-se à aplicação, com o cuidado de verificar e sanar qualquer dúvida sobre o significado de cada alternativa.

Entre as alternativas oferecidas, os respondentes podiam assinalar três dificuldades, em ordem de relevância, ou escrever e enumerar outras, se, eventualmente, quisessem pontuar uma dificuldade que não constava na lista. Com a mesma liberdade, se alguém considerasse que não havia três dificuldades para marcar, poderia marcar apenas duas ou uma.

Os resultados foram tabulados de duas maneiras: em primeiro lugar, efetuou-se a somatória absoluta das indicações para cada alternativa, acrescentando mais três pontos extras citados por três respondentes. Em segundo lugar, foi contada a frequência de respostas para cada dificuldade, por ordem de relevância. A quantificação verificada pode ser visualizada na Figura 16 e na Figura 17. 
Figura 16 - Principais dificuldades apontadas pelos estudantes

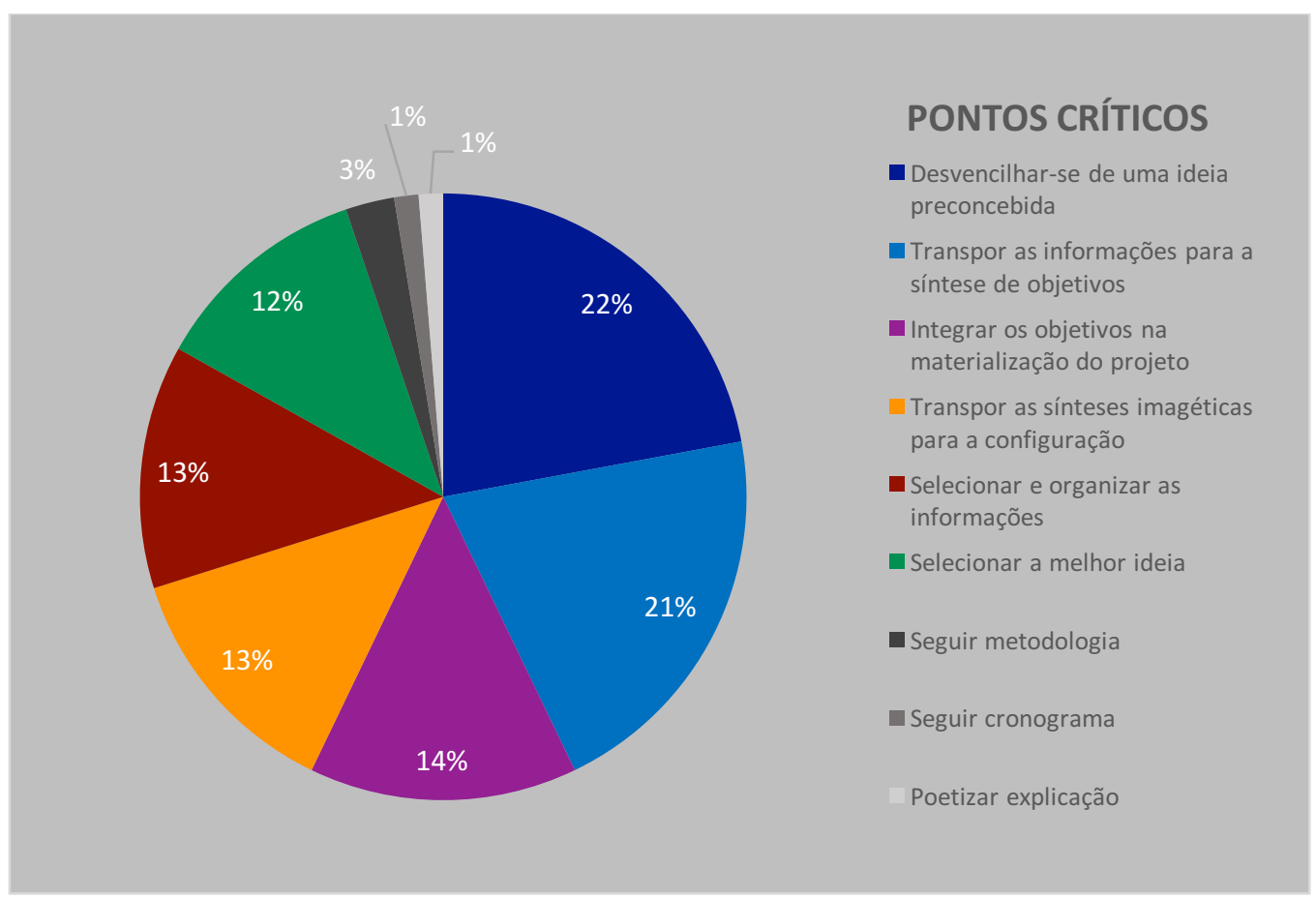

Fonte: Elaborado pela autora com base na pesquisa realizada (2014)

Figura 17 - Dificuldades listadas em ordem de relevância decrescente de 1 a 3

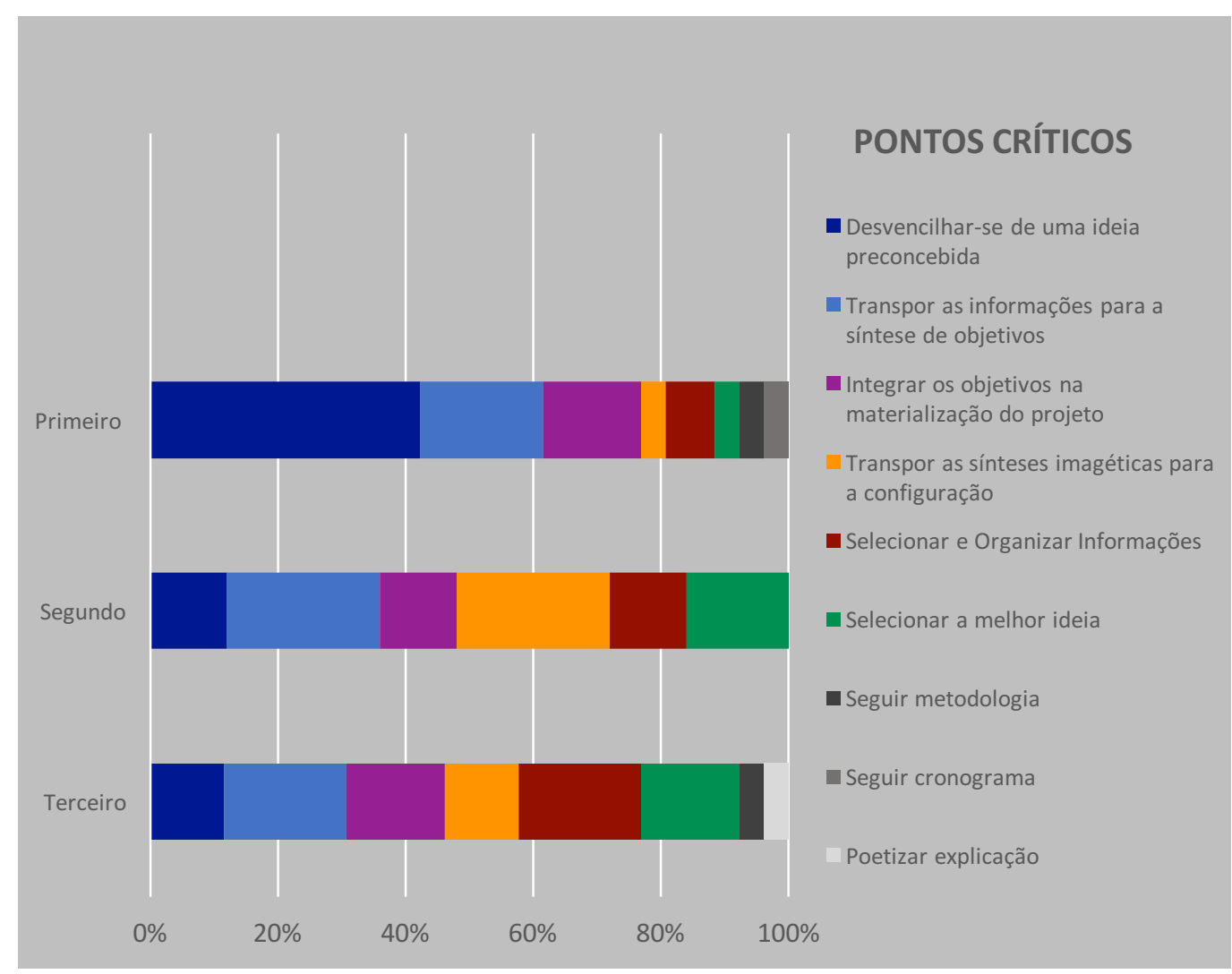

Fonte: Elaborado pela autora com base na pesquisa realizada (2014) 
Os resultados apontaram como maiores dificuldades o empecilho enfrentado ao se apegar a uma primeira ideia e a transposição das informações em objetivos. Embora a alternativa sobre os objetivos ocupasse o segundo lugar para a maioria dos alunos, a recorrência desta nos três níveis de relevância a equiparou em importância.

As outras alternativas constantes no questionário tiveram um valor absoluto semelhante, mas observou-se maior constância na ênfase do tópico "integrar os objetivos na materialização do projeto". No entanto, houve uma grande incidência no tópico "transpor sínteses imagéticas para a configuração", confirmando-o como segundo em importância e como foco de atenção nas estratégias metodológicas.

\subsubsection{DIAGNÓSTICO}

Considerando que o contexto investigado já era profundamente assimilado pela pesquisadora, o diagnóstico se concentrou em confirmar observações preliminares e identificar pontos específicos relacionados ao problema estudado.

As opiniões dos estudantes ratificaram as dificuldades em relação à decodificação das sínteses imagéticas e à gestão das informações que, se considerada a recorrência das colocações sobre o custo em se desvencilhar de uma primeira ideia, sugere uma deficiência de meios para ampliar a exploração divergente e a carência na definição de objetivos para direcioná-la.

Unificando a análise documental às opiniões coletadas, confirmou-se essa deficiência na integração dos objetivos para a delimitação projetual e a necessidade de melhor aproveitamento das sínteses visuais para impulsionar e ampliar as possibilidades da geração de alternativas.

A identificação dos níveis de experiência estabelecidos com o vestuário, também averiguada na análise das fichas-síntese, marcou a premissa de que a delimitação projetual deve atender objetivos de adaptação física, expressão pessoal e representação social, marcando os quesitos que interagem na forma projetada e que devem ser vinculados como delimitadores de configuração.

Com base nestas percepções, foram delineados os indicadores de atuação em campo: gestão da informação que integre melhor as variáveis (delimitação sistêmica); 
melhor aproveitamento das ferramentas de síntese imagética (facilitar a identificação dos elementos sintáticos e semânticos); experimentação tridimensional agregada à sintaxe da configuração; ferramentas que permitam a fluidez do pensamento divergente e também estimulem as conexões para a convergência das informações em objetivos.

Por outro lado, a conexão das bases teóricas esclareceu a confluência de conceitos e conhecimentos para guiar as atividades práticas. Na Figura 18 foram representados os posicionamentos assumidos em cada camada de fundamentos, do âmbito geral para o específico. O esquema realça o processo educacional de Design de Moda como um processo que é delineado pelo contexto contemporâneo e concretizado sobre estratégias projetuais e pedagógicas (em laranja), para alcançar seu fim, que é o de projetar interfaces para vivenciar o contexto.

Figura 18 - Convergência dos direcionadores para interação em campo

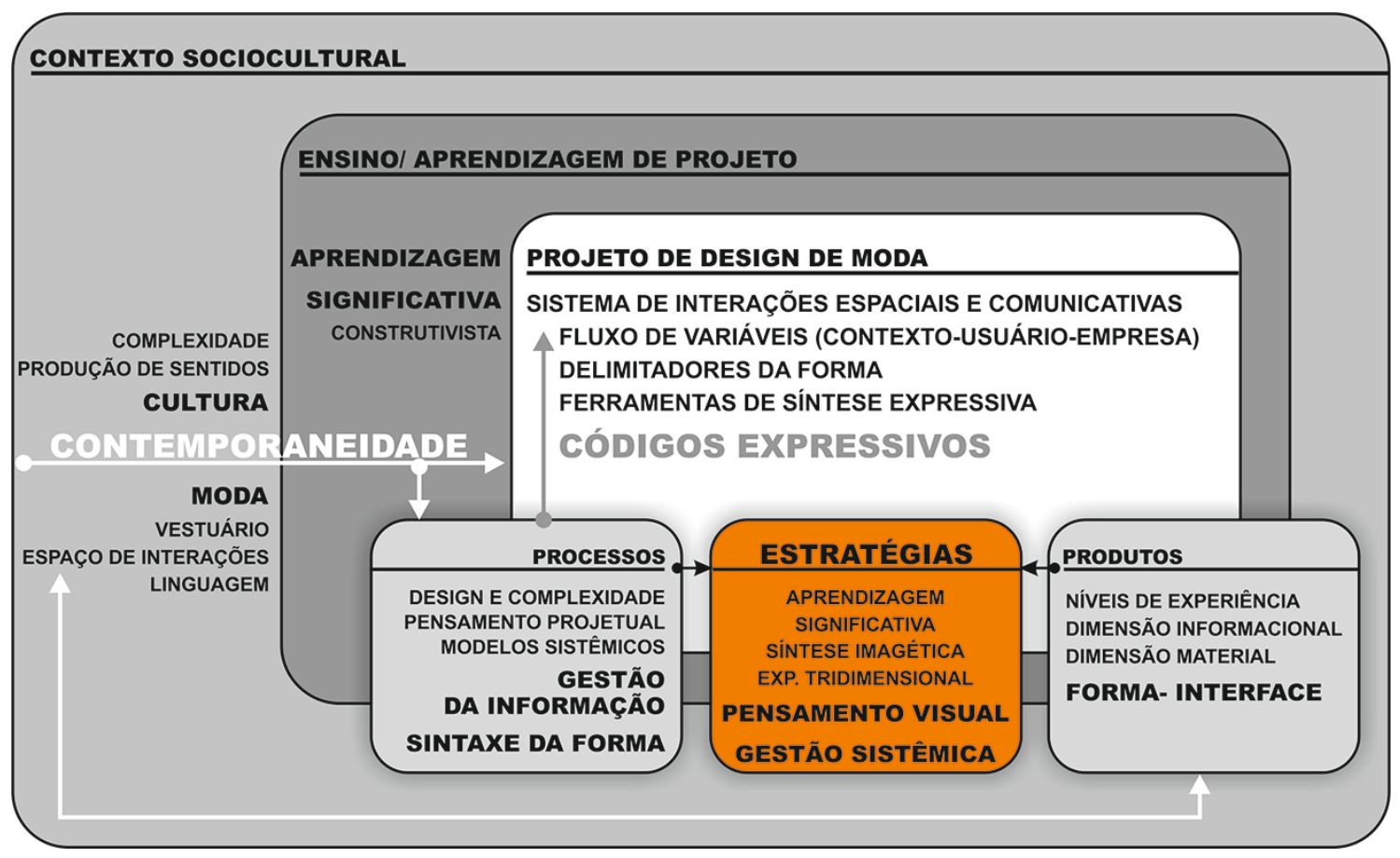

Fonte: elaborada pela autora com base na pesquisa realizada (2014)

A partir deste encadeamento, e amparadas pelo diagnóstico anterior, foram elaboradas as estratégias pedagógicas e projetuais para a entrada em campo, as quais serão relatadas no próximo tópico. 


\subsection{SÍNTESES ESTRATÉGICAS}

A análise dos aportes teóricos distinguiu um trajeto de conexões entre os campos de conhecimento estudados e permitiu identificar a convergência dos direcionadores da pesquisa, os quais foram ilustrados na Figura 19.

Figura 19 - Mapa de conexões dos campos de conhecimento

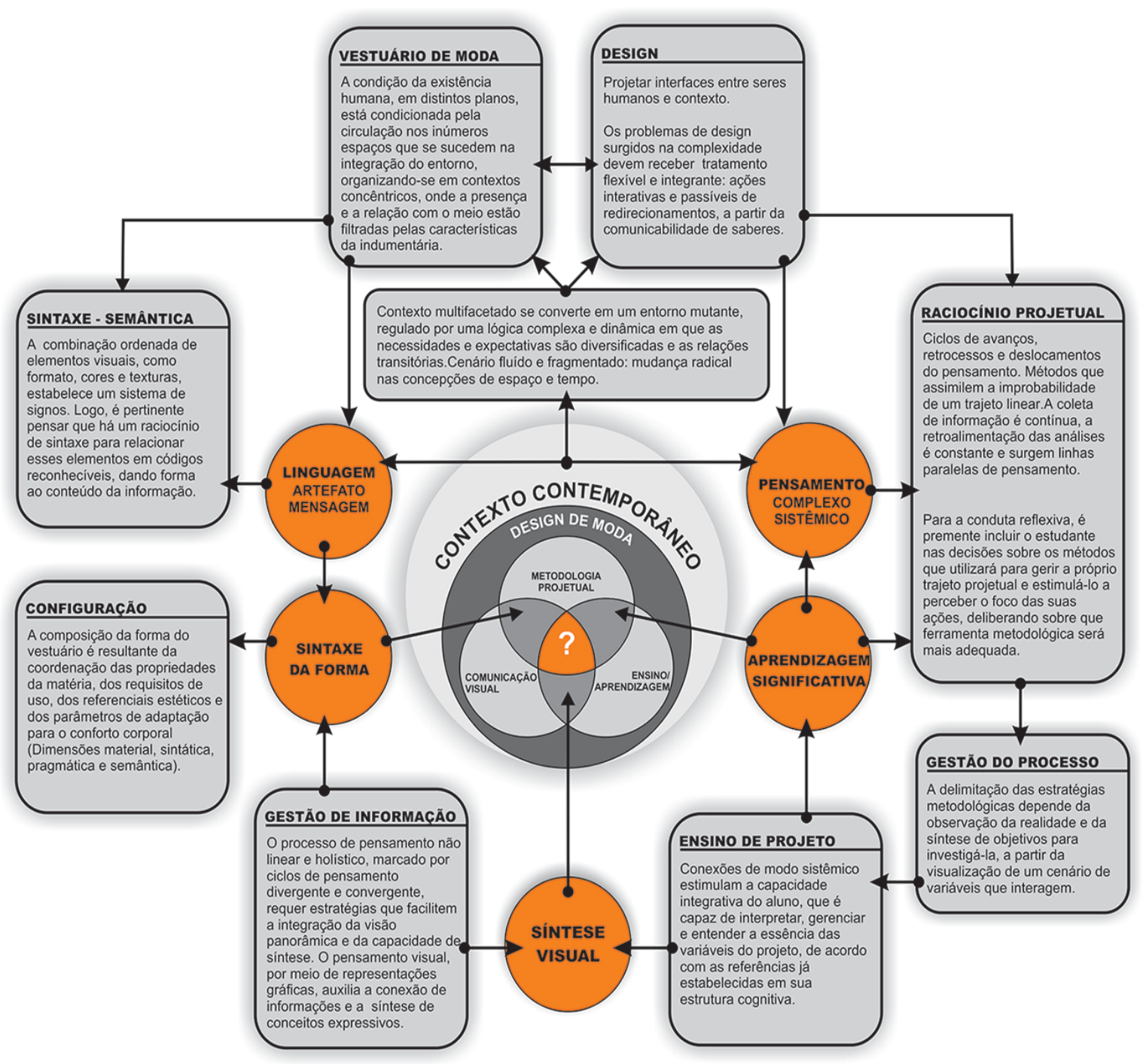

Fonte: elaborada pela autora com base na pesquisa realizada (2014)

O mapa de conexões dos conhecimentos assimilados nas bases teóricas foi elaborado a partir da seguinte linha de raciocínio: o contexto contemporâneo, as interações do vestuário de moda neste contexto e as estratégias para projetar esta interface. O trajeto de correlações detectou o pano de fundo da complexidade, desmembrando duas constatações: em primeiro lugar, o vestuário como espaço de 
interações multifacetadas, altamente dependente de variáveis socioculturais e, em segundo lugar, a premência de abordagens sistêmicas e métodos flexíveis para gerir o design deste tipo de artefato. A partir destas duas vertentes foram ressaltados os aportes sobre a configuração (sintaxe da forma) do vestuário de moda e sobre a gestão do projeto em uma ótica educacional. Identificou-se uma convergência que indica a diretriz da aprendizagem significativa e o uso do pensamento sistêmico e visual como estratégias de ação. Os círculos, em cor laranja, realçam os principais conceitos que regem esta pesquisa, os quais estão conectados com as áreas de interseção dos grandes campos do estudo.

A associação de tais conceitos aos indicadores de atuação em campo (delimitação sistêmica; aproveitamento da síntese visual; integração de pensamento divergente e convergente) proporcionou as bases estruturais para organizar a plataforma de delimitadores e ações de projeto, derivando as estratégias para as interações práticas no âmbito educacional estudado, conforme descrito nas próximas explanações.

\subsubsection{DELIMITAÇÃO PROJETUAL NO DESIGN DE MODA}

O processo projetual emerge das solicitações do contexto e finaliza submergindo, outra vez, na mesma realidade que o definiu, transformando-a e, possivelmente, influenciando novas solicitações. É oportuno esclarecer que, diante do enfoque desta pesquisa, nas qualidades perceptivas da forma, as análises sobre a interface artefatoentorno deram ênfase às interações do artefato em uso, visto que sua qualidade comunicativa não se estabelece na ausência de um observador/ usuário/sujeito social. Porém, isso não deve ser entendido como desabono das repercussões contextuais do produto em todo o seu ciclo de vida. Assim, recomenda-se que as sínteses expostas neste tópico sejam observadas com essa cautela, lembrando que foram distinguidos os elementos que afetariam diretamente a sintaxe formal/visual.

Esta perspectiva guiou a análise sobre as informações que definem as condicionantes projetuais no Design de Moda. Para a empreitada, foram relacionados os agentes envolvidos no desenvolvimento de produtos de vestuário de moda 
identificados nas bases teóricas e na análise documental, a partir dos quais se explicitam as categorias de informações que influem na delimitação projetual, ponto chave desta pesquisa.

Além dos delimitadores provenientes da relação usuário-produto, foi considerado que o designer de moda costuma estar inserido diretamente no ambiente industrial, ou de alguma maneira atrelado a uma empresa/mercado ( $\mathrm{RECH}, 2002$; MONTEMEZZO, 2003; SANCHES, 2011; TREPTOW, 2013), cooperando com outros profissionais, e limitado por uma realidade produtiva bastante extensa. Além disso, convém relembrar que o projeto pedagógico do curso estudado prioriza a integração entre as atividades acadêmicas e o contexto produtivo/mercadológico, tendo em vista que Londrina está localizada em um importante polo nacional de indústrias de vestuário. Por esse motivo, é fundamental incorporar empresa e produção às análises.

Não faz parte do escopo desta pesquisa analisar estratégias de mercado ou examinar questões controversas sobre a geração de demandas e obsolescência programada. A intenção é somente construir um panorama do fluxo de informações que transitam entre contexto sociocultural, universo do usuário e ambiente corporativo/produtivo. Por um lado, é necessário saber onde vive e que perfil corpóreo tem o usuário, os códigos com que este se comunica, as influências socioculturais que absorve, a disponibilidade de consumo, suas necessidades cotidianas e expectativas sociais. Por outro lado, é fundamental conhecer como se organiza e se posiciona, ao que visa e que recursos dispõe a empresa que pretende atender às demandas desse sujeito.

Com base nos estudos da delimitação projetual do design de moda e apoiadas pelas análises da experiência de uso (detectadas na análise documental), distinguiu-se categorias de informação primordiais para a delimitação neste estudo. Mesmo que a representação na Figura 20 não transmita a riqueza ou o dinamismo dos mecanismos ali explicados, a intenção é estimular uma apreensão direta e coesa, facilitando a percepção da estrutura geral do sistema de relações. Desta maneira, é possível sintetizar a rede de informações relevantes para o planejamento de diretrizes, critérios e restrições projetuais. Também se adverte que a separação em caixas e cores tem fins didáticos, apenas para realçar as categorias de informações primordiais e representar, por meio de uma cor secundária (verde) que mescla duas primárias (azul e amarelo), a 
interação dos universos usuário e corporativo, imersos em um universo sociocultural (cinza), interagindo continuamente.

Figura 20 - Fluxo de informações entre os agentes influenciadores do Design de Moda

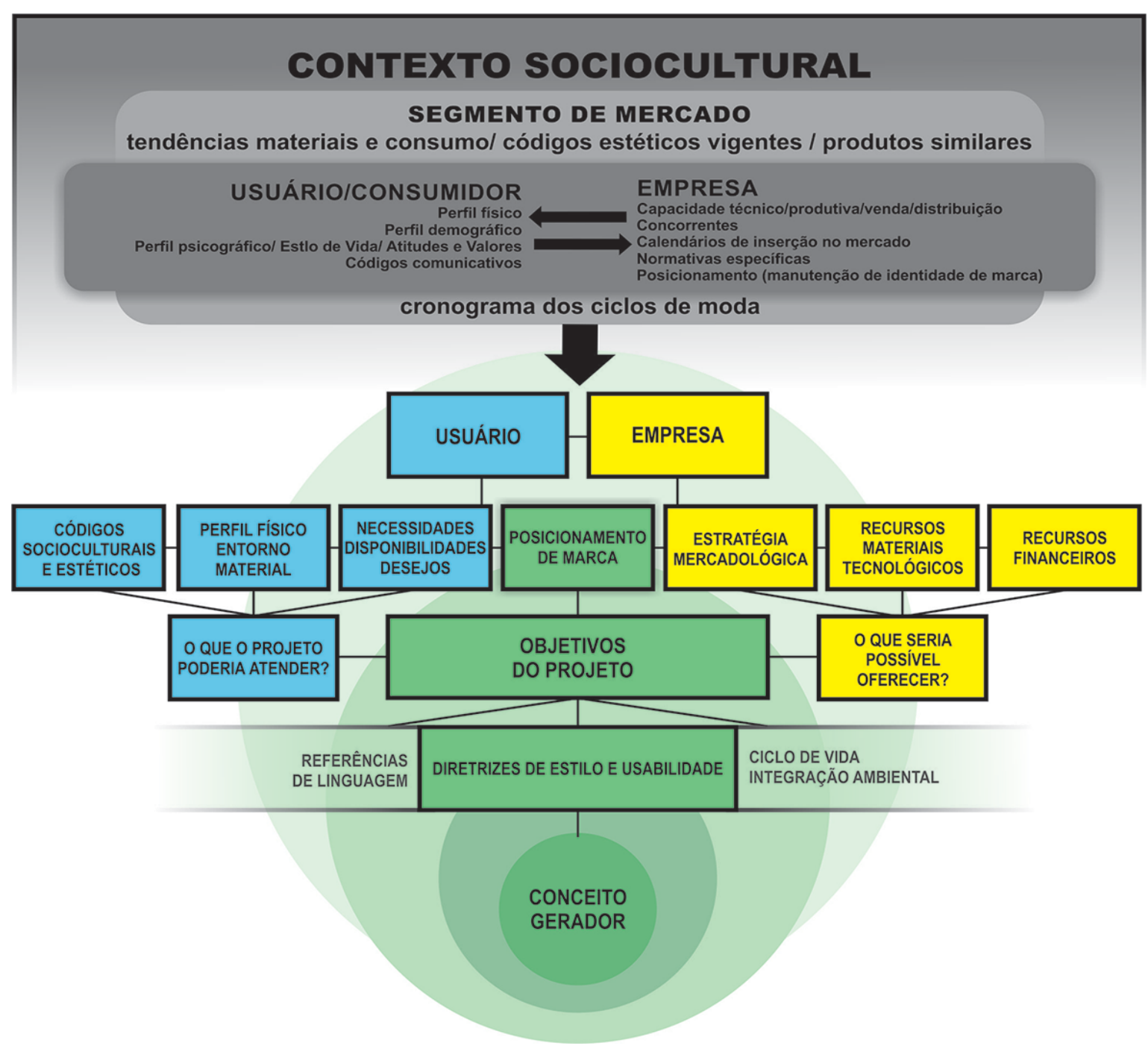

Fonte: Elaborado pela autora, adaptado de Sanches (2011)

Os conjuntos de informações implicados no processo de delimitação projetual frequentemente estão sobrepostos ou interpolados, cabendo aos envolvidos no projeto o desafio de decodificá-los como variáveis de entrada no sistema projetual. Para reforçar que a representação (Figura 20) não descreve um sistema fechado, as camadas circulares ao fundo lembram que o fluxo de informações é cíclico e que ideias incipientes de solução costumam surgir antes da definição clara dos objetivos, podendo aguçar a percepção da demanda projetual estudada. 
Neste esquema, é preciso compreender os termos usuário e empresa de forma ampliada. Usuário compreende a noção de sujeito(s) a quem se destina o artefato projetado, uma entidade que integra componentes físicos, psíquicas e sociais, e empresa engloba a noção de entidade que produz e insere produtos (tangíveis ou intangíveis ${ }^{52}$ ) de moda no ambiente humano. Dessas entidades, foram priorizadas as classes de informações indispensáveis para orientar a prática projetual na formação, exaltando que as soluções encontradas são afetadas por esses dois universos e devem oferecer uma resposta simultânea às expectativas de quem usa e de quem produz/vende. Assim, é importante ressalvar que o esquema apresentado visa auxiliar a organização das informações básicas da delimitação projetual, mas cada projeto deverá nutrir-se na pesquisa do contexto que o abarca. A conjuntura que envolve o projeto fornece informações e também indicadores para conectar tais dados, conferindo à pesquisa e à gestão de informação papéis essenciais no entendimento da experiência que proporcionará o artefato projetado. Logo, projetar a forma requer a compreensão dos processos de utilização do artefato, significa entender que relações este intermedeia entre os usuários e o entorno.

Retomando Bomfim (2014a), enfatiza-se que o processo de utilização é determinante para a constituição da figura (forma). No campo da moda, é comum atrelar a função à ocasião de uso. Por exemplo, um casaco é, na sua essência utilitária, uma peça que cobre boa parte do corpo com a finalidade de aquecer, contudo sua aparência pode indicar que ele se presta a cobrir um vestido de festa ou uma roupa de academia, informando sobre a ocasião ou ambiente de uso. Logo, além do aspecto prático de aquecimento corporal, o enunciado visual do casaco é prontamente interpretado como signo de um determinado contexto. Em consequência, explanar sobre a função do vestuário de moda é pisar em "terreno movediço", pois o termo pode ser empregado como utilidade prática, material e objetiva, conduzindo à noção de proteção física do corpo. Porém, se for percebido de modo amplo, como resposta ao questionamento "para que serve?", provavelmente, levaria a ideias como "enfeitar o corpo", "cobrir a nudez do corpo" ou, ainda, "expressar o estilo pessoal”. Nesta direção,

\footnotetext{
52 A despeito de o vestuário de moda ser, em princípio, um objeto tangível, dotado de uma estrutura espacial palpável, é conveniente recordar que as empresas ofertam tais produtos imersos em um composto de itens comunicativos para constituir uma imagem de marca (essência intangível).
} 
a função incluiria aspectos subjetivos e menos tangíveis, como a expressão individual e o pudor.

De qualquer modo, dois fatores são realçados: a interdependência material com o corpo e a faceta comunicativa como parte de sua função no cotidiano humano. Castilho (2004) reforça que o corpo é o suporte ativo e sensível do vestuário: sua configuração anatômica se integra à configuração do artefato que o cobre, constituindo um espaço comunicativo compartilhado.

Por este motivo, se aborda conjuntamente os equacionamentos que influenciam a elaboração da forma do vestuário de moda, ponderando que a tecnologia e o corpo oferecem possibilidades materiais à forma. Já a função, unificando adaptação corporal e uso social, vincula a configuração a quesitos físicos e psicológicos.

Ponderando as reflexões anteriores, as variáveis mostradas na figura precedente foram atreladas às análises sobre a experiência de uso, para sintetizar os parâmetros que norteiam a sintaxe formal do vestuário de moda (Figura 21), denominados delimitadores da forma.

Figura 21 - Delimitadores da forma a partir das variáveis do contexto

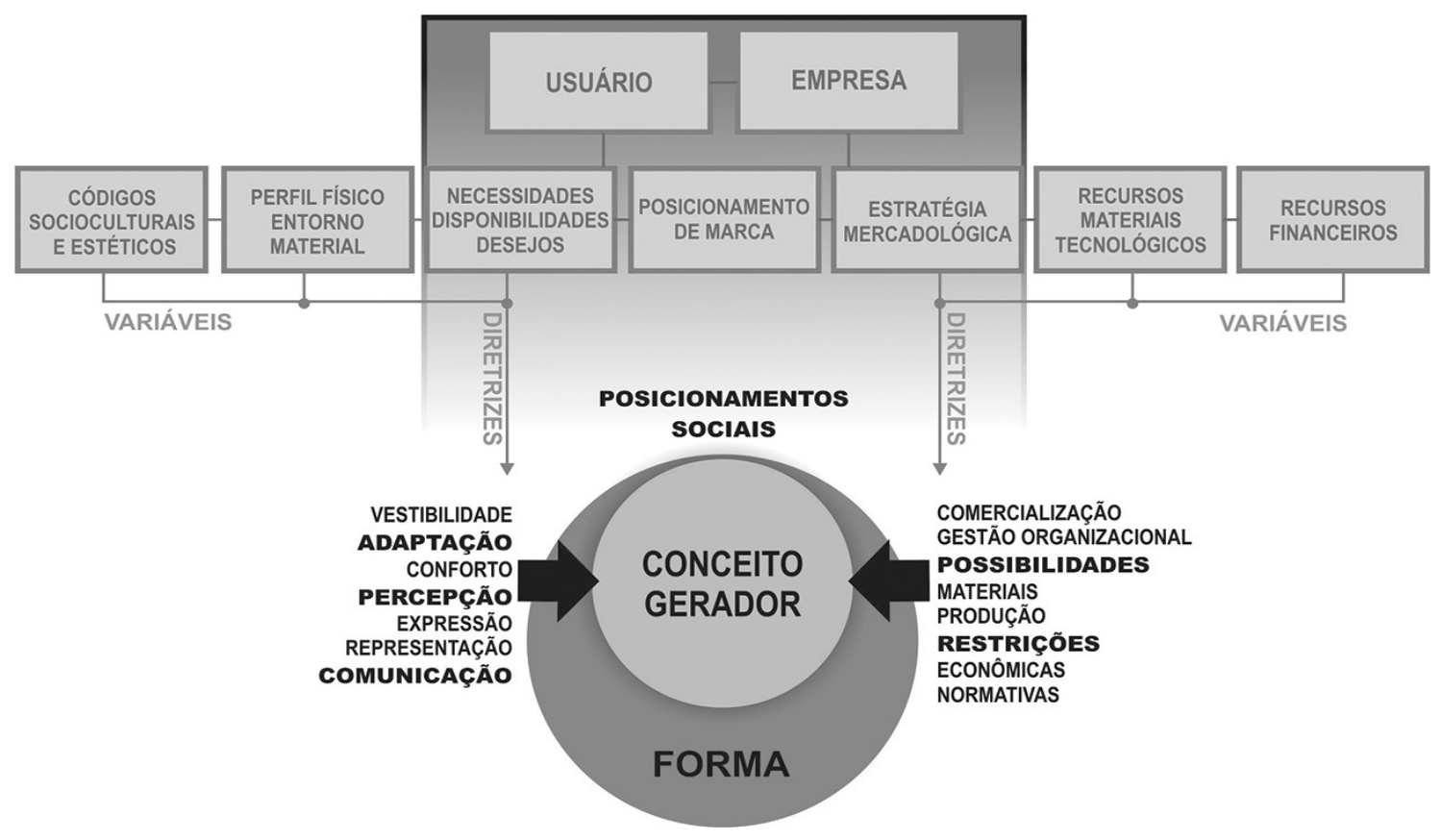

Fonte: elaborado pela autora com base na pesquisa realizada (2014)

É relevante salientar dois pontos transversais a qualquer projeto de design de moda: a) as possibilidades e restrições dependem, além das demandas do usuário/ 
contexto e capacidade tecno-produtiva, de fatores econômicos e dos ciclos temporais que se vinculam ao sistema da moda; b) embora o impacto socioambiental (posicionamentos sociais) seja um delimitador transversal a qualquer projeto de design e muito estimulado no ambiente educacional em estudo, a assimilação de posicionamentos sustentáveis dependerá, sobretudo, da filosofia de gestão da empresa.

O estudo integrado das condicionantes provenientes do usuário, da empresa e do contexto que os envolve origina as diretrizes apontadas na Figura 21, as quais se transformam em objetivos de projeto. Por exemplo, um entorno material/geográfico situado em uma metrópole, somado a um estilo de vida acelerado, poderia originar objetivos como: adaptar-se a diversos ambientes, variar a aparência. Esses objetivos, por sua vez, poderiam designar o conceito "transformável" para a configuração.

Assim, a associação das informações conflui para um conjunto de diretrizes que influenciam, diretamente, o planejamento da sintaxe da forma. De um lado, os requisitos de adaptação física, percepção subjetiva e representação social que envolvem o usuário, de outro, as estratégias mercadológicas, as possibilidades e as restrições produtivas e comercias da empresa. Esses requisitos definem os delimitadores da forma: possibilidades e restrições oferecidas pelos materiais e tecnologias disponíveis, pontos da anatomia corpórea que requerem maior proteção, conforto ou ênfase visual, signos de representação social, referenciais de conteúdos expressivos (Figura 22).

Figura 22 - Conjunto de Influências atuantes na sintaxe formal/visual.

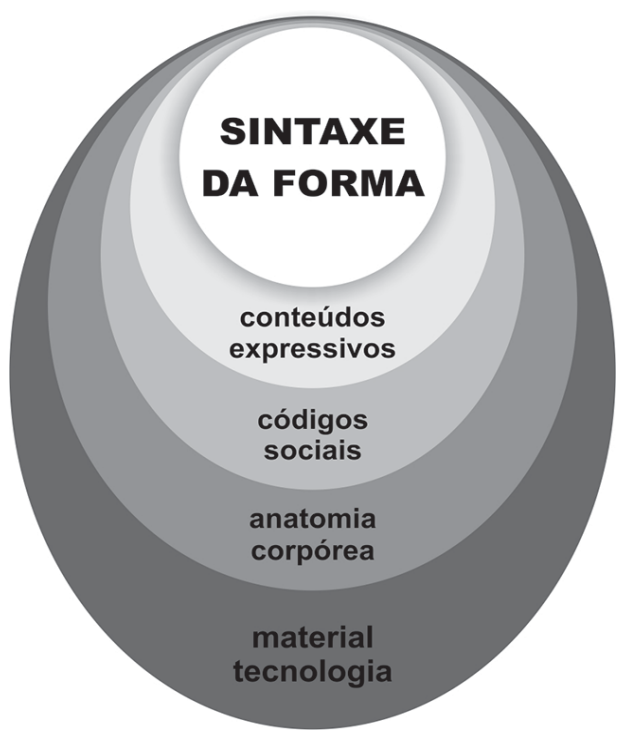

Fonte: elaborado pela autora com base na pesquisa realizada (2014) 
A integração dos delimitadores e sua consequente influência na materialização da configuração, dependem da gestão das ações e de procedimentos que compõem a prática do design de moda. O trajeto entre uma questão de projeto e a sua resposta é esboçado pelo planejamento de ações fundamentais e o gerenciamento das ações decorrentes daquelas primeiras, aferindo os quocientes de incerteza e diversidade realçados nos estudos teóricos sobre o processo de design. Para facilitar esse planejamento nas práticas em campo, a próxima síntese expõe as ações fundamentais de design para a elaboração do vestuário de moda.

\subsubsection{AÇÕES PROJETUAIS NO DESIGN DE MODA}

Se o processo de design constitui um sistema permeável que pode se transformar, constantemente, na interação com o entorno, é inegável que solicita do designer competência integradora e habilidade de gestão para perceber e conectar as informações que participam do sistema, definindo estratégias que convertam as conexões em possibilidades de solução coerentes. Faz sentido argumentar, então, que este percurso é também um processo de gestão de informação e construção de conhecimento, no qual reside uma essência de pesquisa aplicada. A cada situação projetual existe a necessidade de desvendar universos, identificar questionamentos, formular objetivos, sintetizar conceitos, experimentar propostas e comunicar soluções.

A referência à pesquisa, no entanto, não sugere uma condução projetual pelo método científico, apenas ressalta que a busca organizada de informações (teóricas ou empíricas) para conhecer e solucionar o problema, realizada de maneira crítica e reflexiva, requer uma atitude investigativa, uma disposição para indagar e buscar respostas fundamentadas. Independentemente das diferenças entre a investigação científica e o design, critérios científicos podem estar inclusos no trajeto projetual como, por exemplo, na coleta de dados em campo (LESSA, 2011, p.40).

Deste modo, fica claro que, para alcançar os objetivos deste estudo, se deve elucidar, além dos delimitadores elencados anteriormente, focos norteadores para as ações projetuais e habilidades necessárias para gerir o fluxo de conhecimentos do sistema projetual. 
É inevitável que ao estudar o ensino/aprendizagem, nas esferas da formação profissional, se acerque a ideia de pontuar as habilidades e competências necessárias para o profissional em questão. No entanto, a dificuldade já começa pela distinção de sentido entre estes dois vocábulos. No senso comum, os termos habilidade e competência são, frequentemente, usados como sinônimos; já entre professores é habitual verificar o termo competência relacionado a um modo estratégico de enfrentar uma situação e habilidade ser referendada em um nível mais operacional. Valente (2002) fez um levantamento sobre este tema e concluiu que, entre os estudiosos da área educacional, não há consenso sobre os conceitos de habilidade e competência, os quais se mostram ora diferenciados, ora inseparáveis. A autora observa que competências e habilidades pertencem à mesma família e que a distinção entre elas é determinada pelo contexto. Uma habilidade, em dado contexto, pode envolver outras habilidades mais específicas e ser entendida como competência.

Sobre este tema, nota-se que alguns teóricos do design citam as habilidades e competências que a formação profissional do designer deve construir, mas não se ocupam de aclarar estes limites difusos. Igualmente, o documento das Diretrizes Curriculares para o Ensino de Graduação em Design coloca-as em um mesmo conjunto. Por isso, foi assumido que o interessante para esta pesquisa é enumerar certas aptidões importantes a serem desenvolvidas no transcurso da formação projetual, sem a inquietação de categorizá-las nestes termos, visto que, certamente, remetem a capacidades integradas. Pelo qual, decidiu-se usar o termo habilidade para designar a capacidade de mover recursos internos para agir diante de uma situação.

Agir de forma pertinente e eficaz perante uma situação do contexto solicita a mobilização de conhecimentos, valores e tomada de decisões. Em estudos sobre projeto, essa descrição é muito familiar, pois cada ação projetual é acompanhada de uma conjunção de operações do pensamento para decidir os procedimentos que serão realizados. É inegável que procedimentos, ações e habilidades se vinculam, intrinsecamente, no decorrer do processo projetual, sendo um recurso importante para expor a estrutura das ordenações efetuadas nesta investigação.

Sobre a plataforma construída por Sanches (2010; 2011), observa-se que existem quatro grandes conjuntos de procedimentos comumente utilizados na prática do design de moda em âmbito acadêmico: a) procedimentos para contextualizar e sintetizar 
parâmetros projetuais (ATENDER-ABRANGER)-; b) procedimentos para gerar e experimentar possibilidades de conexão dos parâmetros, delineando possíveis soluções (INOVAR-DEPURAR); c) procedimentos para avaliar e refinar a eficácia e decorrências das possibilidades geradas (DEPURAR-SEDIMENTAR); d) procedimentos para consolidar a viabilidade tecno-produtiva, humana e social das propostas. (SEDIMENTAR).

Embora essa organização dos procedimentos sugira uma lógica de etapas, a autora ressalta que tais conjuntos não formam uma cadeia linear, tampouco acontecem isoladamente, incorrendo habitualmente em ações simultâneas e sucessivos ciclos de interação ou realimentação. Por isso, o uso dessa classificação dos procedimentos não se presta a desenhar um trajeto padrão, mas a relacionar de forma didática as ações primordiais para construí-lo a cada projeto. Mesmo assim, é possível confirmar a interpretação do cenário sociocultural como ponto de partida e observar uma correlação de ações transformadoras ${ }^{53}$, que apontam três focos projetuais: explorar o contexto e identificar relações referenciais (DELIMITAR); experimentar combinatórias dos referenciais e multiplicar as possiblidades (GERAR); avaliar e canalizar as possibilidades para uma proposta viável e factível (AVALIAR/CONSOLIDAR). Entre esses focos se observa um fio condutor, no qual se poderia distinguir "fases" de uma evolução processual, mas também se constata que, para "focalizar" as ações, sucederão ciclos recorrentes de análise, síntese e avaliação, em que estarão agindo processos divergentes e convergentes, como assinalado por Lawson (2011). Assim, ocorrem interseções, avanços e retrocessos, reivindicando um tratamento metodológico que admita esse movimento.

Para Bomfim (2014c, p.67), os procedimentos metodológicos devem permitir a visualização do projeto como um sistema complexo, de variáveis que interagem simultaneamente, e não como uma "sucessão de dados cumulativos que se sobrepõe.

\footnotetext{
53 Ação é percebida sob a ótica piagetiana, considerando que a construção do conhecimento se dá por meio da ação sobre o objeto (de estudo); a adaptação da mente à realidade é fruto da interiorização das ações. Entendendo o raciocínio projetual de modo sistêmico, é pertinente afirmar que cada ação realizada neste processo tem o propósito de articular e organizar as relações que compõem o percurso de projeto; neste sentido, tais ações são também transformadoras do sistema projetual e do conhecimento ali construído.
} 
O projeto não é uma reta estática entre o problema e a resposta, mas uma espiral em que cada segmento é mais denso que seu antecedente".

Por isso, discutir o instrumental metodológico para direcionar essas ações focalizadas requer o conhecimento das aptidões/habilidades intrínsecas à prática projetual, ou seja, as capacidades que possibilitam a efetiva realização do projeto. Neste rumo, Lawson (2011), apoiado nas análises de Cross (2000), classifica as habilidades implícitas às ações projetuais.

A) Formular - reúne as habilidades para encontrar e expressar os problemas, entendê-los e examiná-los.

B) Representar - envolve as habilidades de exteriorizar as ideias e os pensamentos, para comunicar, organizar ou rearranjar informações, conceitos incipientes, problemas e objetivos projetuais.

C) Movimentar-se - relativo à capacidade de realizar os sucessivos deslocamentos de pensamento para conectar ideias, interpretá-las e desenvolvê-las.

D) Avaliar - refere-se à capacidade para avaliar e decidir, à competência para julgar alternativas com base em critérios e tomar decisões sobre que rumo seguir.

E) Refletir - habilidades ligadas ao esforço consciente para manter o projeto no rumo dos objetivos; presupõe a supervisão da própria conduta no decorrer do trajeto projetual.

Cabe assinalar que, embora sejam discutidas as habilidades concernentes à condução do projeto, as quais estão em posição de destaque nas ações pedagógicas da disciplina de Metodologia do Projeto, elas são exercitadas de modo transversal em todas as unidades curriculares do curso e, obviamente, a construção de suas bases se inicia muito antes do estudante chegar ao ensino superior.

Regressando aos focos projetuais identificados anteriormente, é plausível uma aproximação entre estes e as habilidades apontadas por Lawson (2011). O foco delimitar requer as aptidões do conjunto de habilidades para formular; gerar se conecta 
às habilidades de representar e movimentar-se e, naturalmente, avaliar/consolidar se liga às capacidades de avaliar e refletir.

Convém advertir que, como as ações de projeto incidem em ciclos, as habilidades também dinamizam o processo de maneira transversal, a exemplo das habilidades de avaliar e refletir, que são empregadas sempre que o foco for convergente.

Por fim, é possível retomar as variáveis projetuais apontadas anteriormente, relacioná-las como parte do fluxo de ações identificadas e entender como se organizam, de acordo com as categorias de habilidades envolvidas (Quadro 11). O paralelo entre estes aspectos referenda os grupos de conhecimentos essenciais para guiar a pesquisa (teórica e empírica) na prática projetual do Design de Moda. Embora a representação esquemática não transmita o dinamismo das interações citadas, acredita-se que facilita a apreensão da estrutura geral do sistema de relações presentes no processo de Design de Moda. Contudo, destaca-se que, apesar da aparente sequência lógica de etapas, as linhas pontilhadas e setas de duplo sentido tentam reforçar que os processos mentais e as ações praticadas se vinculam de modo cíclico e, muitas vezes, simultâneo.

Quadro 11 - Conexão entre os focos das ações projetuais e habilidades correspondentes

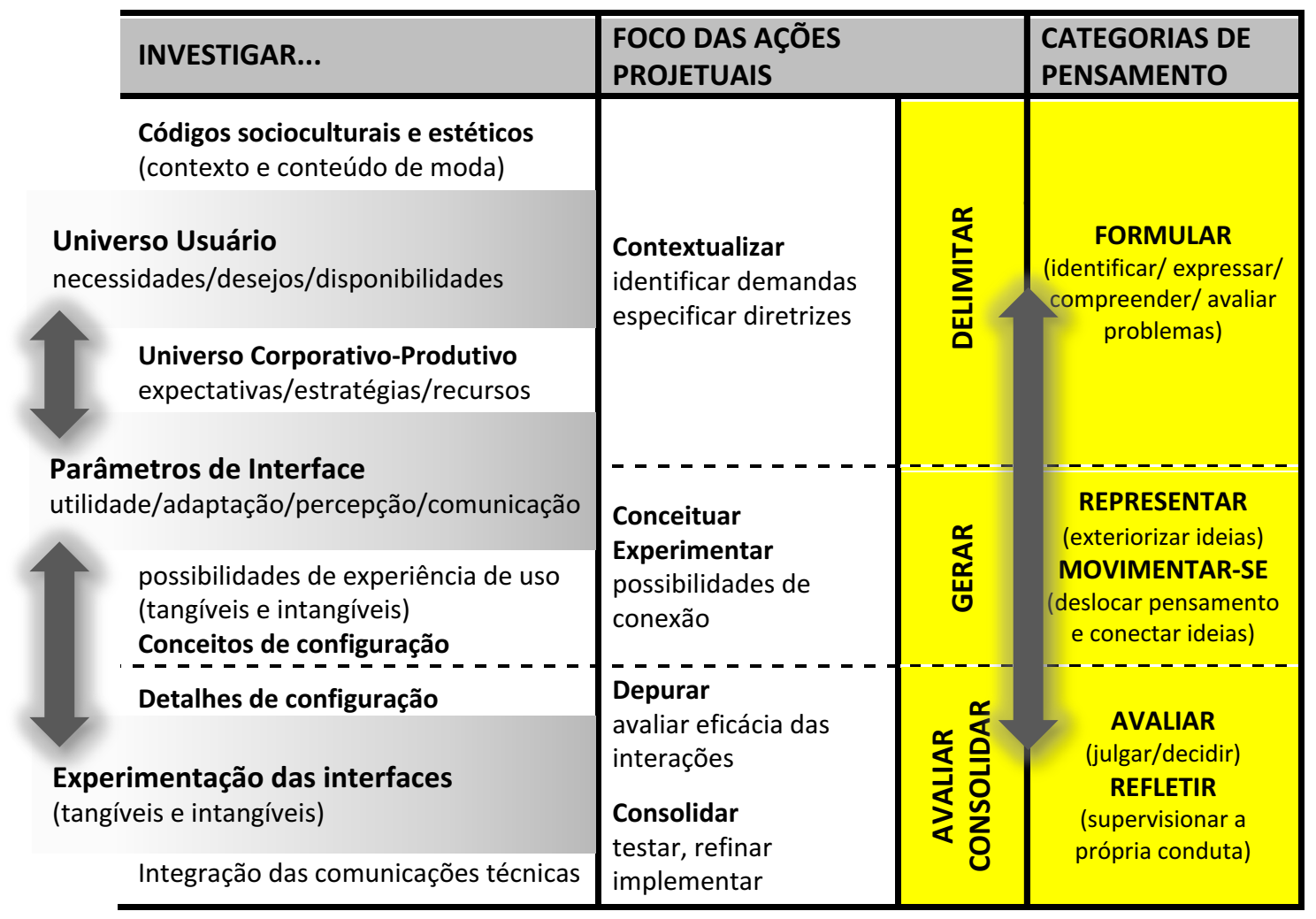


Nesta macroestrutura, é possível perceber um espaço de investigação (teórica e prática) que gera conhecimento, no qual as estratégias de ação podem ser selecionadas, de acordo com o foco de cada ocorrência projetual. Por conseguinte, a diretriz pedagógica deverá proporcionar a construção do conhecimento autônomo e reflexivo, formando a habilidade para se ajustar à variabilidade de contextos e problemas de design.

Para alcançar a conduta reflexiva, apontada por Schon (2000) e Lawson (2011), é premente incluir o estudante nas decisões que definem os métodos utilizados para gerir o próprio trajeto projetual e estimulá-lo a perceber o foco das suas ações, deliberando sobre que ferramenta metodológica será mais adequada e definindo também um olhar metaprojetual. Abrem-se parênteses para aclarar que a intenção de uma prática reflexiva, na presente pesquisa, não insinua um posicionamento de supervalorização do fazer, a intenção é realçar que a construção do conhecimento passa por uma vivência fundamentada e significativa.

Vale ressaltar que, devido à importância do uso social e produção de sentidos conferidos aos artefatos dos quais se ocupa o design de moda, seria ingênuo reduzir o processo projetual à apreciação isolada do produto, sem considerar as múltiplas assimilações contextuais ou a relevância da pesquisa para entendê-las. Com isso, a reflexão e a postura investigativa são quesitos que deveriam estar intrínsecos à formação de designers neste campo. Igualmente, a premissa de uma fase projetual de exploração investigativa que adentra o contexto para definir - e redefinir - estratégias de ação do projeto, instalando uma plataforma de gestão de conhecimentos, parece natural, quando amparada na ideia da gestão projetual sistêmica e na visão do artefato como interface (tangível e intangível) entre homem e entorno sociocultural.

Justamente neste espaço de exploração do contexto é que a presente pesquisa se insere. Tendo em vista que o escopo deste estudo está centrado em estratégias que facilitem a delimitação projetual e a conexão com a geração de possibilidades expressivas para a forma, há um perceptível acoplamento com as ações focadas em contextualizar, conceituar/experimentar. Com isso, a ação metodológica proposta foi situada no momento da exploração contextual e da gestão dessas informações para sintetizar conceitos expressivos. Isto significa utilizar ferramentas que integrem a visão panorâmica e a capacidade de síntese, fluidez divergente e focalização convergente. 
Para tanto, o instrumental metodológico em estudo deve ativar as habilidades de formular, representar e movimentar-se, balizando-as pela capacidade de avaliar.

É notório que, para alcançar tal meta, a gestão da informação, e sua transposição em objetivos e conceitos, demanda estratégias que possibilitem o fluxo de linhas paralelas de pensamento e de conexões simultâneas. A este respeito, nota-se um distanciamento de concepções lineares (problema-análise-solução) sobre o processo de design, passando a iniciativas metodológicas de abordagem multifocal, na tentativa de delinear uma trajetória projetual mais holística e entrelaçar as inúmeras influências do contexto.

Portanto, entre as estratégias que apoiam este estudo, foram enfatizadas as que atendiam as seguintes premissas: a) abordagem sistêmica, b) permeabilidade para a gestão de informação, c) valorização do pensamento visual. Sob esta diretriz, no curso da busca, encontrou-se o Modelo de Diseño Concurrente, proposto pelo Prof. Bernabé Hernandis Ortuño, da Universidade Politécnica de Valencia.

\subsubsection{DISEÑO CONCURRENTE}

O Modelo de Diseño Concurrente ${ }^{54}$ foi criado pelo prof. Hernandis por ocasião de sua pesquisa de doutoramento e visa à gestão das informações para a integração de objetivos e síntese conceitual no projeto de produtos. Com base em uma estrutura de múltiplas relações, exalta a comunicabilidade contínua entre as variáveis projetuais e situa o projeto como um sistema interdependente do contexto em que se insere.

A partir da identificação das dimensões fundamentais que constituem o design de produtos, o modelo articula a informação em uma estrutura gráfica que propicia análises independentes e também simultâneas. Hernandis $(2003 ; 2012)$ explica que o contexto gerador da demanda constitui um sistema amplo e aberto ("Sistema Exterior") que compreende, alimenta e influencia o "Sistema de Referência" (ou "Sistema em Estudo"), no qual ocorre a integração das variáveis de projeto e a formulação de

\footnotetext{
54 A denominação "concurrente" [concorrente] se relaciona à geometria, referindo-se ao que se encontra em um mesmo lugar geométrico. Por conseguinte, percebe-se a ideia de convergência de direções a um foco comum. Tendo em vista que é uma denominação própria e que esta é uma tese realizada em cotutela espanhola, decidiu-se não traduzir a expressão.
} 
diretrizes para possíveis soluções projetuais. Por sua vez, o "Sistema de Referência" abrange três "Subsistemas Fundamentais" de inter-relações (delimitados por cores distintas), alojando os quesitos funcionais (vermelho), ergonômicos (verde) e formais (azul). Este modelo permite a gestão visual das informações, abrindo espaço para a inserção de imagens e representações gráficas sintéticas dos conceitos gerados.

De acordo com Hernandis (2003; 2012), no modelo, o subsistema funcional reúne os objetivos relativos à tecnologia, aos mecanismos, aos materiais, etc. 0 subsistema formal se relaciona à aparência, à ordenação dos elementos configurativos, incluindo informações como cores, texturas, aspectos de proporção visual. Por fim, o subsistema ergonômico maneja as informações que dizem respeito às vinculações com o usuário, abordando os aspectos funcionais e formais sob os parâmetros perceptivos e de adaptação física.

Para cada subsistema propõe-se uma análise decompondo volumes, superfícies e limites de contorno, examinando, assim, as características funcionais, formais e ergonômicas para estes aspectos da geometria (configuração) do produto. A intenção é perceber especificidades de volume, de superfícies e de limites de contorno em relação ao uso, para cada subsistema. Para esclarecer, entende-se por volume de uso a delimitação geométrica tridimensional, a qual define o espaço necessário às funções específicas e concretas do produto, sendo distinguida em termos funcionais, ergonômicos e formais. De modo análogo, as superfícies de uso, as quais delimitam os volumes anteriormente identificados, podem ser examinadas distinguindo as incursões específicas para cada subsistema. Como limite de contorno, Hernandis (2003; 2012) nomeia o lugar geométrico que delimita uma superfície ou volume, sobre o qual é possível fazer considerações conceituais, mas que não são identificáveis como volumes ou superfícies concretas de uso. A amplitude de movimento de uma parte móvel do produto, por exemplo, originará um limite espacial que deve ser previsto entre os requisitos do produto.

As decomposições auxiliam a compreensão das relações dos elementos com os objetivos funcionais, ergonômicos e formais, porém o intuito é entendê-las no conjunto do sistema. O modelo promove uma ordenação integrada das análises e prevê que, a cada decisão tomada sobre uma variável dentro de um subsistema, haverá uma informação resposta que a inter-relaciona com os outros subsistemas, podendo 
provocar um rearranjo geral do Sistema de Referência (ou Sistema em Estudo). Assim, o sistema é realimentado de informação de todas as suas partes, e a todos os níveis.

Vale esclarecer que, ao definir como foco de análise os volumes e superfícies de uso, e eventuais limites de contorno que se relacionam com tais elementos, foi estabelecido um parâmetro que é aplicável a qualquer produto, já que configurar um produto significa definir como se organiza sua materialidade, de acordo com as necessidades de uso (prático ou estético-simbólico). Contudo, o grau de relevância que se atribui a cada volume ou superfície e a decisão de considerá-lo no sistema dependerão do repertório do designer que, no âmbito desta pesquisa, representaria o conhecimento prévio construído por meio de pesquisa.

Entre o Sistema Exterior e o Sistema de Referência transitam as variáveis de entrada e de saída. As variáveis de entrada influenciam os fatores a considerar no projeto aportando valores, qualitativos ou quantitativos que atuam no sistema, sob a forma de requisitos a serem atendidos. Quanto as variáveis de saída, constituem-se a partir da atuação da solução projetual sobre o Sistema Exterior. Toda resposta procedente do sistema em estudo pode ter um efeito sobre o sistema que o gerou, ou podem ser alterados por ele, os produtos, os serviços, a comunicação técnica, os resíduos, etc. Este aspecto aproxima-se à noção de permeabilidade, comentada anteriormente. Para melhor compreensão, a Figura 23 mostra o diagrama do modelo.

Figura 23 - Modelo de Diseño Concurrente

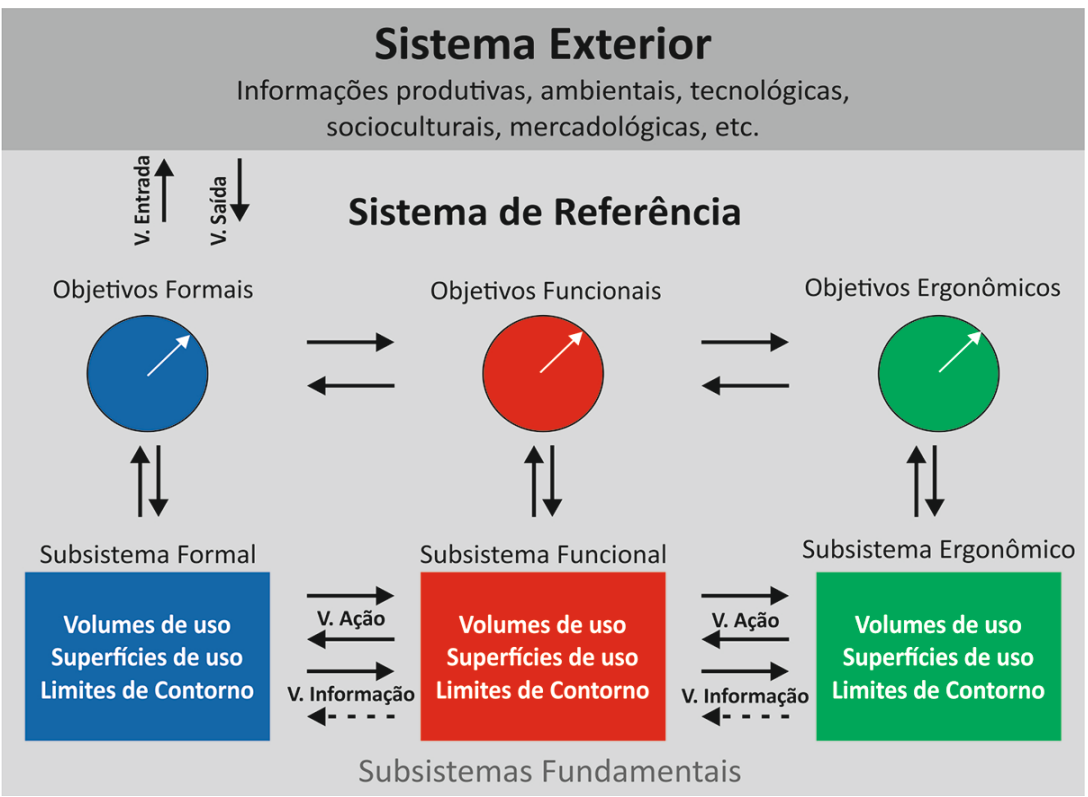

Fonte: traduzido de Hernandis (2012) 
No interior do Sistema de Referência, as variáveis provenientes do contexto originam interações que promovem o movimento de inter-relações entre os subsistemas fundamentais. No dinamismo das conexões, um conceito sintetizado em um subsistema pode transformar um objetivo já estabelecido em outro subsistema ou provocar a percepção de um requisito ainda não considerado.

O modelo de Diseño Concurrente é uma ferramenta de trabalho teórica, na qual se investigam as relações entre as informações disponíveis, gerando novas informações (verbais ou não verbais) que promovem a visualização do produto em nível conceitual. Como já mencionado, a ferramenta assimila representações gráficas, as quais são utilizadas como meio para analisar, em conjunto, os conceitos sintetizados. Para tanto, os objetivos são estudados, primeiramente, distinguindo suas implicações em cada subsistema e permitindo a percepção dos delimitadores para os componentes configurativos (volumes, superfícies e limites de contorno). A partir disso, é possível gerar representações básicas da estrutura formal, analisar as interações dessas sínteses e continuar evoluindo os estudos gráficos até visualizar um conceito volumétrico que sobreponha delimitadores funcionais, ergonômicos e formais, o qual foi denominado por Hernandis, como espaço de design.

A gênesis deste modelo é a organização sistêmica do conhecimento existente e do conhecimento gerado no trajeto projetual. Assim, foi reforçada a indicativa de uma abordagem pedagógica pelos preceitos da aprendizagem significativa, para que uma ferramenta de gestão integrada de informação fosse atrelada às práticas em classe.

\subsubsection{ESTRATÉGIAS DE ENSINAGEM}

Retornando ao contexto educacional estudado, como já especificado, a adoção do enfoque da aprendizagem significativa foi considerada pertinente e, mais que isso, uma premissa para adentrar o campo, visto que havia um estudo precedente e o traçado metodológico da pesquisa previu que as interações deveriam promover um ambiente colaborativo e respeitar as características naturais do contexto. Com o mesmo propósito de respeitar o entorno didático, naquele universo, já introduzindo uma perspectiva de aprendizagem significativa, buscou-se o aporte de conhecimentos prévios que 
permeavam a prática projetual dos alunos participantes. Neste sentido, destaca-se a familiaridade com o conceito de metaprojeto e a valorização da pesquisa na ensinagem de projeto.

Esses direcionadores foram introduzidos na disciplina de Metodologia do Projeto a partir das pesquisas de Miotto (2014), a qual sintetiza uma proposta que relaciona a aprendizagem significativa, projeto e pesquisa.

É possível relacionar a atividade do design a um modelo de aprendizagem significativa, em que os conceitos e conteúdos particulares do designer influenciarão, diretamente, nos resultados do projeto. Estes, por sua vez, só serão positivos se o profissional desempenhar papel de pesquisador de novos conceitos e possibilidades para associá-los ao que se conhece, alcançando, assim, a inovação. A partir destas relações, o processo de desenvolvimento de produtos pode ser esquematizado, durante o ensino dos conceitos do design, na forma de uma ampulheta (MIOTTO, 2014, p.99).

Figura 24 - Processo de desenvolvimento de novos Produtos (em aprendizagem significativa)

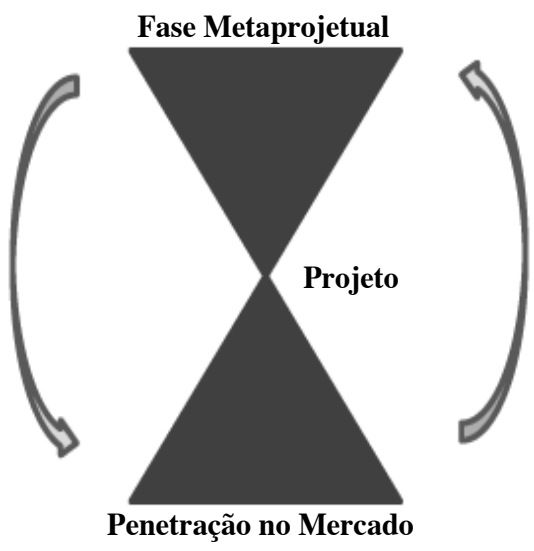

Fonte: Miotto (2014)

Para ela, o topo caracteriza a fase metaprojetual (MORAES, 2010 apud MIOTTO, 2014) do processo, em um espaço de reflexão que une teoria e prática, para identificar possíveis cenários para o produto (Figura 24). Neste espaço são estudados fatores de interação humana, socioculturais e ambientais, mercadológicos e tecno-produtivos. Sob o foco da aprendizagem significativa, é o espaço de construção de novos conceitos, em que o aprendiz se esforçará em obter novos significados para objetos e eventos ocorridos no entorno.

O centro afunilado, ainda segundo Miotto (2014), representa a fase do projeto efetivo do produto, quando o designer filtra as informações analisadas na fase 
metaprojetual e as combina, criativamente, aos conteúdos já existentes em sua estrutura cognitiva, gerando alternativas de solução. No processo, ferramentas específicas de projeto facilitam a articulação dos conceitos adquiridos em variáveis de projeto. Este instrumental metodológico auxilia o processo de seleção dos conceitos e dos significados disponíveis na estrutura cognitiva do designer. A experimentação concreta, por meio de testes e prototipagem, permitirá a visualização de novas possibilidades, derivando novos significados e conceitos para os profissionais envolvidos no processo.

A autora explica que a base da ampulheta sugere a penetração do produto no mercado. Este, que assimila ou não um produto, pode apresentar sinais de novas demandas. Assim, "ao virar a ampulheta, tem-se novamente o início do processo metaprojetual, com a análise e prospecção de cenários, delimitações de necessidades e especificações de projeto, produção e lançamento de novos produtos, fazendo com que este processo seja um ciclo infinito de possibilidades de atuação e inovação" (MIOTTO, 2014, p. 100). Essa visão cíclica leva a deduzir que o processo de design consolida o conhecimento ao final de um projeto e desperta novos olhares e desejo de descobrimento, ao propor novas possibilidades de ação.

Na organização de Miotto (2014), é possível tecer uma aproximação com o olhar de Vassão (2010), o qual infere o projeto como pergunta, grifando a contínua ressignificação deste. Para ele, mesmo que o designer se ocupe da solução de um problema, os objetos que projeta sempre derivam de reinterpretações e configuram novas questões no universo do indivíduo ou da comunidade. Da mesma forma, as inferências surgidas na investigação bibliográfica, sobre o processo projetual, como sistema permeável e imbricado ao contexto sociocultural, se ajustam a estes posicionamentos preexistentes no universo pesquisado.

Como já registrado, o aporte mercadológico é outro ponto relevante no projeto pedagógico do curso, sendo também uma diretriz para a ação em campo. De acordo com Anastasiou (2010), no atual cenário de ensino superior é necessário que sejam propostas condições em que os estudos de diversas áreas possam convergir em torno de situações reais, buscando a teoria necessária à compreensão das mesmas. Desta maneira, o curso de Design de Moda da UEL desafia os estudantes a desenvolverem projetos que se ligam à realidade com grau de complexidade crescente. 
Em vista dos preceitos supracitados e das conexões das teorias pedagógicas, foram resumidos, no Quadro 12, os pontos essenciais do posicionamento pedagógico que a pesquisa assumiu.

Quadro 12 - Pontos-chave do posicionamento didático-pedagógico

\begin{tabular}{|c|c|}
\hline \multicolumn{2}{|c|}{ ESTRATÉGIAS PEDAGÓGICAS } \\
\hline APRENDIZAGEM SIGNIFICATIVA & $\begin{array}{l}\text { - } \text { assimilação via conhecimento preexistente; } \\
\text { - } \quad \text { procionar a ensinagem à experiência vivida; } \\
\text { - } \text { significativamentção para apreender } \\
\text { relação colaborativa aluno-professor; }\end{array}$ \\
\hline PESQUISA CONTINUADA & $\begin{array}{l}\text { manter foco investigativo em todo o trajeto; } \\
\text { projetual como meio de construção de novos } \\
\text { conhecimentos; }\end{array}$ \\
\hline INTERFACE EXTRAMUROS & $\begin{array}{l}\text { inserir parâmetros mercadológicos e } \\
\text { contextos reais do setor produtivo na gestão } \\
\text { da prática projetual. }\end{array}$ \\
\hline
\end{tabular}

Fonte: elaborado pela autora com base na pesquisa realizada (2015)

Finalmente, quando as estratégias pedagógicas se conectaram às análises anteriores sobre o pensamento projetual, insurgiram três constructos fundamentais para entender a ensinagem de projeto nesta pesquisa: a) permeabilidade plástica: processo projetual como sistema permeável aos movimentos do contexto; b) investigação reflexiva: projetar sobre a plataforma da vivência investigativa e a construção autônoma do conhecimento; c) reflexão integrativa: apreender sistêmica e significativamente, edificando o conhecimento a partir da confluência entre repertório pessoal e saber escolar.

Perante a evidência de um processo que requer uma conduta integrada e crítica, em um ambiente pedagógico que incentiva a construção autônoma do conhecimento e propicia a interdisciplinaridade, propor estratégias metodológicas para a prática projetual depende fortemente da gestão da informação. Isso demanda uma ação para organizar e conectar informações, sintetizar conceitos e, finalmente, produzir um conhecimento significativo. Essa ação foi denominada, no âmbito deste estudo, como gestão sistêmica da informação, referindo-se ao processo no qual se explora a situação projetual, gerando questionamentos e propiciando a construção de relações entre as 
variáveis para a síntese de conceitos. Com vistas à efetivação da gestão sistêmica da informação, no universo investigado, o próximo capítulo discorre sobre as propostas específicas para essa abordagem, apresentando o instrumental desenvolvido no decorrer da pesquisa e relatando os procedimentos de sua aplicação prática. 


\section{CAPÍTULO 6}




\section{PROPOSTAS E INTERAÇÕES}

6 PROPOSTASEINTERAÇOES

Neste tópico serão relatados os fundamentos que apoiaram a proposição das ferramentas usadas nas interações em campo. Este instrumental foi concebido com o propósito de atuar, especificamente, em dois pontos detectados por este estudo: a delimitação projetual e a síntese de direcionadores para a sintaxe da forma.

A partir dos indicadores de atuação em campo, que priorizavam a gestão da informação para integrar as variáveis e o maior aproveitamento das ferramentas de síntese imagética, foram elaborados o Diagrama REC (DREC) e o Mapa de Categorias Expressivas (MCE).

\subsection{PROPOSTA DE INSTRUMENTAL METODOLÓGICO}

Na cronologia da pesquisa, o Mapa de Categorias Expressivas foi a primeira inciativa proposta, pois já era uma estratégia incipiente quando o estudo foi iniciado. As observações prévias da prática docente já haviam assinalado a necessidade de aprimorar a utilização das sínteses imagéticas, levando ao embrião desta ferramenta.

No entanto, as primeiras aplicações evidenciaram a importância da delimitação projetual sistêmica, para que a síntese do conceito gerador facilitasse a definição do verbo de ação, imprescindível para o uso do Mapa de Categorias Expressivas. Assim, a investigação rumou para a elaboração da outra estratégia proposta, o Diagrama REC, atendendo a premissa de interação entre visão panorâmica e capacidade de síntese para facilitar a delimitação projetual. A seguir, explicam-se as bases que conduziram a proposta das ferramentas, em separado, mas que podem ser coordenadas, como relatado na descrição da terceira interação em campo.

\subsubsection{MAPA DE CATEGORIAS EXPRESSIVAS}

O uso de sínteses imagéticas, como painel semântico e mood board, já era bastante valorizado no ambiente estudado, assim como os diagramas gráficos, principalmente, 0 
uso de mapas mentais, cada vez mais frequente entre as ferramentas escolhidas pelos estudantes.

Outra estratégia a ressaltar é a utilização de verbos de ação como ponto de partida para a experimentação da forma. Nas práticas criativas com a modelagem tridimensional (moulage), um verbo é tomado como impulsionador para a manipulação de possibilidades formais, estimulando a transformação de ideias. Assim, o verbo acolher, por exemplo, poderia dar impulso a várias maneiras de movimentar o plano têxtil sobre o corpo e gerar diversas interpretações volumétricas, ou derivar outros verbos para experimentação, como: proteger, abrigar, aconchegar, etc. Este recurso se assemelha a algumas estratégias para estimular a criatividade citadas por Lupton (2013) e Baxter (1998), nas quais se manipula um conceito básico por meio das ações sugeridas por verbos.

Sobre este alicerce de conhecimento prévio, percebeu-se que tais ferramentas metodológicas poderiam ser coordenadas, otimizando o emprego do pensamento visual na síntese de referências para a sintaxe da forma. Considerando estes elementos como já assimilados pela estrutura cognitiva dos estudantes, as bases teóricas da pesquisa bibliográfica e as constatações de observações anteriores em classe, foram construídos os parâmetros para a proposta do Mapa de Categorias Expressivas.

A ferramenta foi concebida a partir de uma combinação de técnicas, incluindo mood board, escala de diferencial semântico, verbos de ação e mapa mental, destinando-se à síntese e comunicação de conceitos de configuração. Com ela pode-se organizar, reunir e filtrar referenciais estético-simbólicos, sintetizando uma estrutura de conexões para o enunciado visual do artefato projetado, na qual se evidenciam possibilidades configurativas.

A partir do uso do Diagrama REC, os estudantes identificam códigos simbólicos e sintetizam o conceito gerador (SANCHES, 2011; SANCHES et al., 2016) por meio de palavras-chave. Tais palavras ajudam a definição de um verbo que, empregado como verbo de ação, constitui o ponto inicial para a construção do Mapa de Categorias Expressivas (MCE).

Dada a relevância das representações imagéticas na cognição e comunicação humana, como assinalado por Motta (2010) e Dondis (1997), o segundo passo na construção do MCE é a realização de uma coleta subjetiva de imagens. Assim, para 
impulsionar a percepção de vertentes expressivas, os participantes do projeto recolhem imagens que consideram representativas da ação sugerida pelo verbo.

De posse destas imagens, o próximo passo é selecioná-las, agrupando representações similares, descartando informações redundantes e identificando conceitos derivadas do verbo inicial. Essa seleção, definida consensualmente entre os participantes do projeto, indica possíveis categorias expressivas para a elaboração de um mapa mental imagético. Para extrair elementos configurativos deste mapa, aplicase uma escala de diferencial semântico, analisando as percepções sensórias (luz, temperatura, toque e gesto) de cada categoria expressiva.

A escala de diferencial semântico, criada por Osgood, Suci e Tannenbaum, mensura as reações emocionais que acompanham uma palavra, um objeto ou uma imagem. A utilização desta escala pode ser resumida do seguinte modo: a partir de dois descritores opostos, situados nos extremos de uma escala em que se apresenta um intervalo de valores, se qualificam as sensações provocadas pelo objeto (palavra ou imagem), conforme se aproximam mais de um extremo ou outro (OSGOOD, SUCl; TANNENBAUM, 1957; MARTINS; THEÓPHILO, 2008).

Finalmente, as mensurações das percepções sensórias, resultantes do diferencial semântico, são interpretadas em cores (luz e temperatura), texturas (toque) e estruturas formais (gesto). A decisão de usar conceitos relativos às sensações de luz, temperatura, toque e gesto, como polaridades da escala de diferencial semântico, baseou-se na experiência docente e confirmou-se nas bases teóricas.

A vivência na condução de disciplinas relacionadas à composição visual derivou estratégias didáticas para facilitar a articulação do pensamento visual entre os alunos. Uma delas consistia em utilizar uma vivência cotidiana (ou concreta) como estímulo para abstrações expressivas. Por exemplo, se a intenção era transmitir uma sensação acolhedora, indagava-se: qual seria a temperatura do acolhimento? Como seria a luz do acolhimento? A partir das percepções subjetivas de quente, frio, claro, escuro, etc., discutia-se sobre cor. Da mesma forma, relacionava-se textura ao toque e o movimento de um gesto às estruturas formais.

Em um segundo momento, as bases teóricas confirmaram que a experiência vivida poderia ser a estratégia para construir uma "ponte cognitiva" (AUSUBEL, 2033; MOREIRA, 1999; 2000) entre um conceito expressivo e a delimitação de princípios 
sintáticos. Para melhor entendimento, a Figura 25 mostra o modelo da escala de diferencial semântico com os elementos sensórios e um exemplo de aplicação, em que é possível perceber as conexões entre tais elementos e as diretrizes expressivas.

Figura 25 - Exemplo de Mapa de Categorias Expressivas

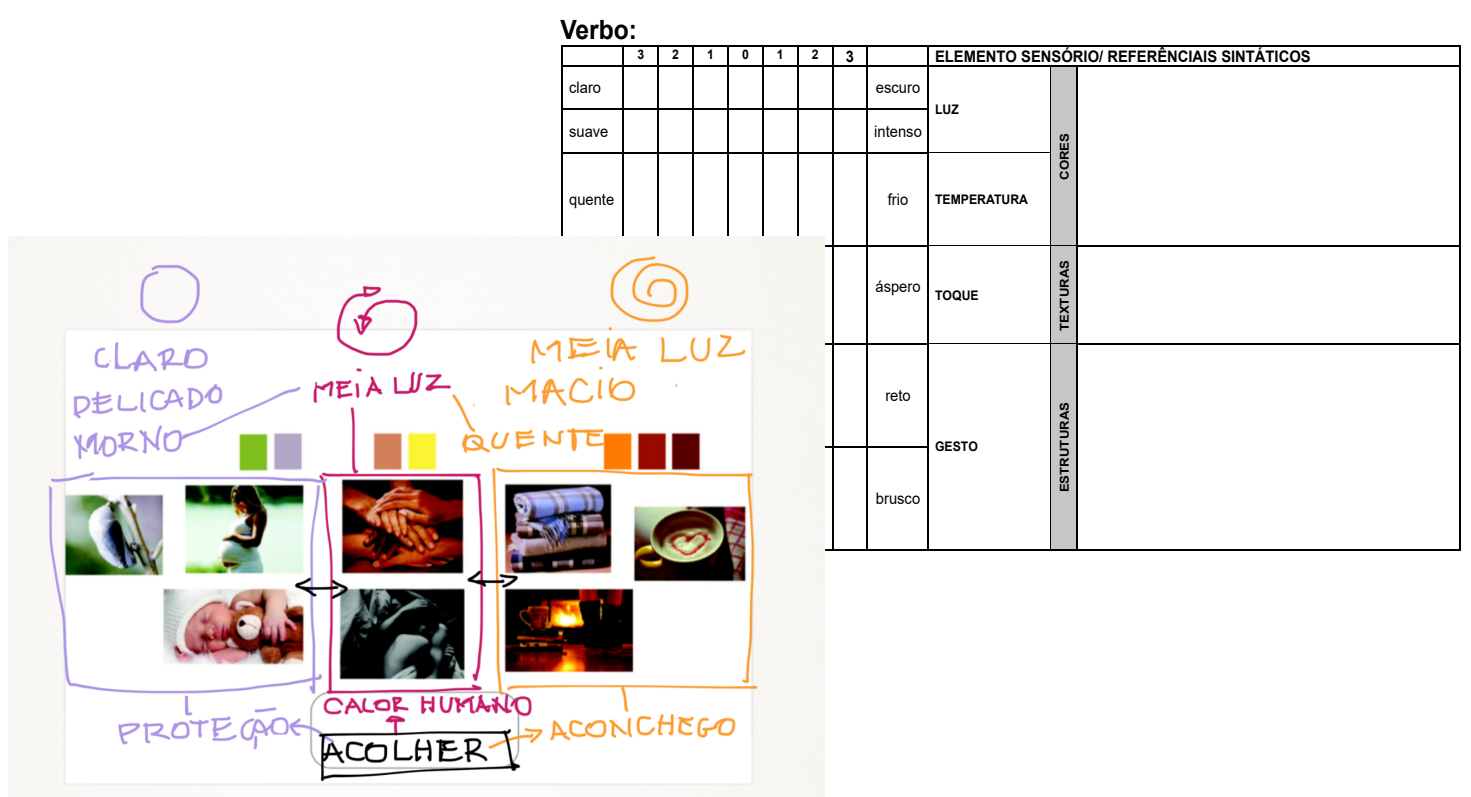

Fonte: Acervo da autora (2013)

O Mapa de Categorias Expressivas possibilita o direcionamento dos elementos sintáticos de modo integrado e ágil. Como síntese gráfica, promove a comunicação entre os participantes de um projeto e facilita as iniciativas de design colaborativo, uma vez que o usuário pode ser incluído na elaboração do mapa mental imagético.

\subsubsection{DIAGRAMA REC}

Reafirmando os já mencionados ciclos dos pensamentos divergente e convergente do processo de design, principalmente, quando a intenção é explorar o contexto e desvendar conexões, marca-se a importância de ferramentas que integrem a visão panorâmica à capacidade de síntese. Em outras palavras, são necessárias ferramentas que permitam a fluidez do pensamento divergente, ampliando o espaço de propagação 
das ideias e a cognição rápida, mas que também acolham conexões direcionadas, propiciando a convergência para sintetizar conceitos.

Neste sentido, a plataforma teórica evidenciou que o uso do pensamento visual, por meio de representações gráficas, favorece a percepção de conexões simultâneas e imprime mais agilidade na compreensão de relações para a associação de informações e ideias (EPPLER; BURKHARD, 2004; EPPLER 2013; ROAM, 2010). Da mesma forma, entre as ferramentas já assimiladas pelos estudantes, os mapas mentais são associados ao pensamento irradiante, como explicado por Buzan e Buzan (1996) e Ontoria et al. (2012), empregando as habilidades de imaginação, associação de ideias e flexibilidade.

Deste modo, foram enfatizadas as sínteses visuais e os mapas mentais como conhecimento prévio a ser aproveitado. Sobre estas estratégias já assimiladas, agregouse a essência do modelo de Diseño Concurrente para delinear a estrutura de uso do Diagrama Radial de Exploração Contextual (Diagrama REC - DREC). Como princípios básicos, a ferramenta deveria incorporar a abordagem sistêmica e valorizar o pensamento visual/gráfico, facilitando, de maneira flexível, a gestão da informação na investigação projetual.

Neste rumo, optou-se pela utilização de uma estrutura gráfica diagramática radial que, integrada à premissa de usar "perguntas-chave" - O que? Quem? Onde? Quando? Como? Por quê? - (ROAM, 2010), para reduzir ou gerar informações, provoca a associação de variáveis e propicia um espaço dinâmico para a visão panorâmica das conexões.

Sobre esta estrutura, cada subsistema do modelo de Diseño Concurrente (HERNANDIS, 2012), e seu respectivo código de cor - funcional (vermelho); ergonômico (verde); formal (azul), alicerçou a delimitação de palavras-chave - utilidade; adaptação; percepção; informação; forma; tecnologia. Posteriormente, essa organização ajudaria a entender as implicações em nível ergonômico, operacional e estético-visual dos objetivos. O propósito, em semelhança ao do modelo de Diseño Concurrente, foi permitir a percepção de delimitadores para os componentes configurativos (volumes, superfícies e limites de contorno) e a geração de representações básicas da estrutura formal do artefato projetado, até visualizar um conceito volumétrico (espaço de design) que equacione delimitadores funcionais, ergonômicos e formais. 
As associações entre perguntas-chave e palavras-chave derivam indagações para a inserção de informações no diagrama, podendo provocar um grande número de questões motrizes que ampliarão a visão do ciclo de interações entre usuário-artefatocontexto. Deste modo, serão identificados os requisitos para delinear situações de uso, níveis de experiência com usuários e indicativos estético-simbólicos.

Além das diretrizes teóricas, a exploração em campo também demarcou parâmetros importantes para a configuração final da ferramenta. As condutas espontâneas das primeiras interações em campo ratificaram uma estrutura circular, de movimento radial, como base para a organização gráfica e registro de informações contextuais, em função da grande recorrência desta opção de registro visual entre os estudantes. A clareza das palavras-chave também foi confirmada em campo, bem como a ordem em que estão dispostas no diagrama, conforme ilustra a Figura 26.

Figura 26 - Diagrama Radial de Exploração Contextual (Diagrama REC)

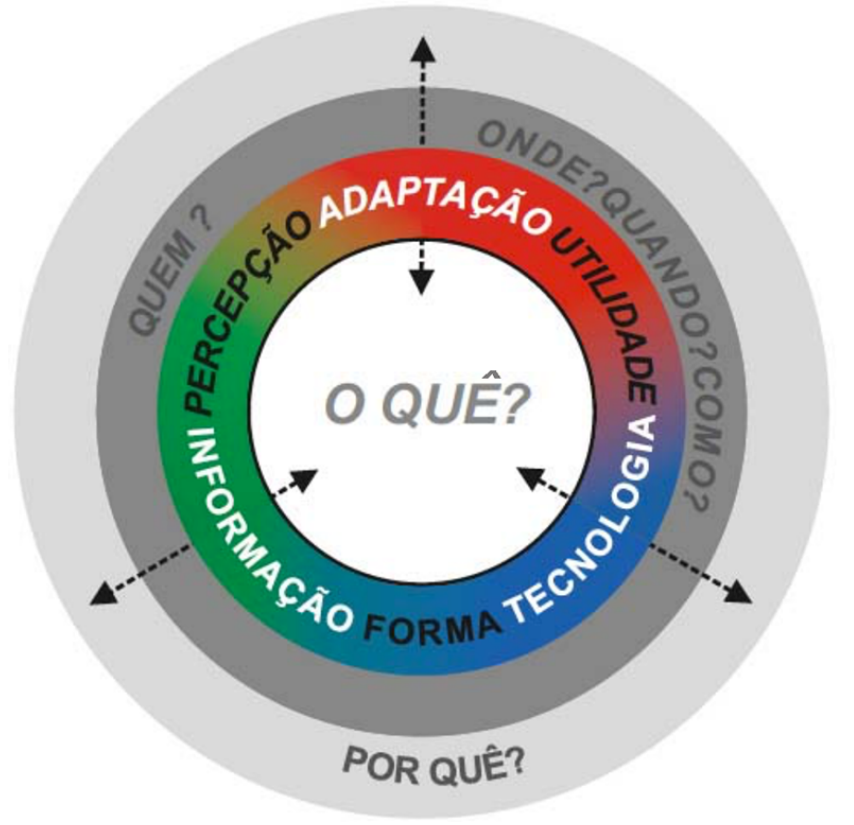

Fonte: Elaborado pela autora com base na pesquisa realizada (2015)

O código cromático apurou a identificação de informações correlatas e a organização de objetivos. No entanto, a ferramenta deveria permitir o remanejamento das informações para a exploração divergente do problema, ou exclusão, quando as conexões apontassem uma convergência; para isso, as notas autoadesivas móveis foram reconhecidas como melhor meio para a mobilidade dos registros efetuados em torno 
do diagrama central. Deste modo, o Diagrama REC serve como impulsionador para a identificação, ramificação, conexão e síntese de informações (Figura 27).

Figura 27 - Exemplo ilustrativo de uso do Diagrama REC

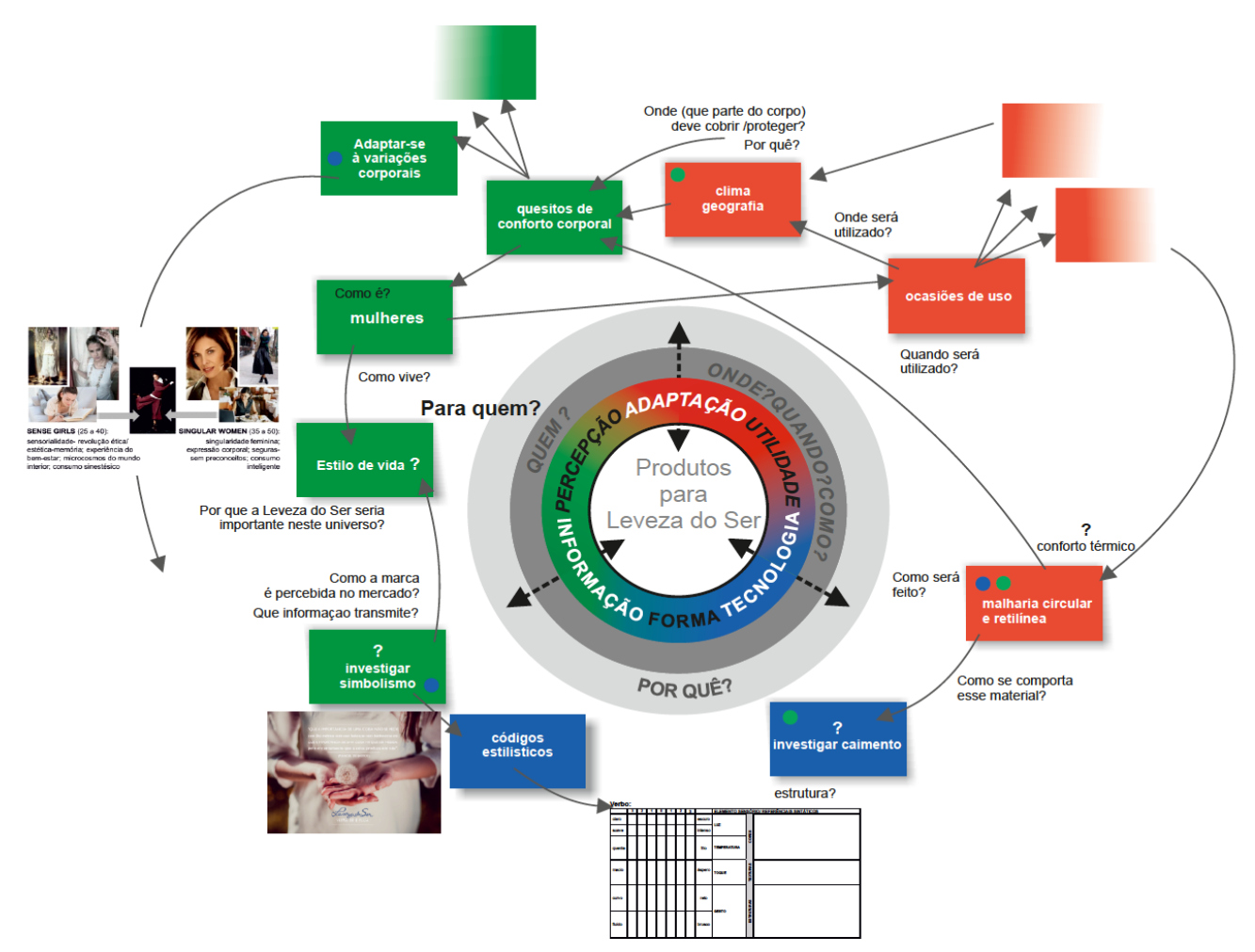

Fonte: Elaborado pela autora com base na pesquisa realizada (2014)

O exemplo ilustra o funcionamento básico do diagrama, visto que uso de informações verbais ou não verbais é livre, bem como a forma de registro gráfico. Como exemplo, são destacados os círculos coloridos, nos cantos dos retângulos de informação: uma forma, entre muitas outras, que os estudantes usaram para assinalar relações simultâneas entre os subsistemas.

O instrumental - MCE e Diagrama REC- interatuou com os estudantes em três momentos distintos: cada ferramenta em separado e, por último, vinculadas. As aplicações em classe propiciaram a percepção dos efeitos de sua utilização na prática projetual e, em face do perfil colaborativo deste estudo, também permitiram a evolução das ferramentas. Com vistas à clareza deste enriquecimento, são explicados os procedimentos em campo e realçados os desdobramentos aportados a cada interação com os estudantes. 


\subsection{APLICAÇÃO EM CAMPO}

Este tópico relatará o planejamento e os desdobramentos resultantes de cada interação, uma vez que as ferramentas evoluíram no decorrer das aplicações práticas. Neste sentido, tais experiências foram relatadas em ordem cronológica, para que o leitor compreenda a evolução das proposições. Cada tópico inclui a descrição da atividade, exemplos ilustrativos, finalizando com a síntese de desdobramentos, os quais foram assimilados na interação seguinte.

\subsubsection{PLANO OPERACIONAL DA PESQUISA EM CAMPO}

O planejamento das atividades práticas foi realizado sobre os indicadores detectados no diagnóstico: delimitação sistêmica; síntese imagética para facilitar a identificação dos elementos sintáticos e semânticos; experimentação tridimensional agregada à sintaxe da forma; interação da fluidez do pensamento divergente com as conexões convergentes para converter as informações em objetivos.

Tal orientação foi alicerçada pelos constructos de permeabilidade plástica, investigação reflexiva e reflexão integrativa para conduzir o processo projetual e a aprendizagem significativa. Deste modo, pretendia-se integrar a gestão sistêmica das informações e a transposição de códigos expressivos para a geração da sintaxe da forma.

A atuação em campo foi distribuída em três momentos, segundo as necessidades de evolução da pesquisa e em conformidade com o calendário acadêmico e o planejamento pedagógico do curso da UEL. A cada intervenção houve, em sequência, realimentações, desdobramentos e novos ciclos de análise para determinar os próximos passos da pesquisa, como explicitado na metodologia desta investigação. Por isso, o plano operacional da pesquisa em campo, apresentado no Quadro 13, é uma síntese do planejamento geral, construído no decorrer do processo, visto que os ciclos da investigação-ação propiciaram a assimilação de novas inferências para melhorar a ação em curso. As barras destacadas em laranja representam novas constatações ou a evolução das sínteses, as quais ocasionaram a adequação do plano e influenciaram o planejamento das ações ulteriores. 
Quadro 13 - Plano operacional da pesquisa em campo

\begin{tabular}{|c|c|c|}
\hline \multicolumn{3}{|c|}{ PLANO OPERACIONAL DA PESQUISA DE CAMPO } \\
\hline ETAPA & OBJETIVOS & ESTRATÉGIAS \\
\hline \multirow{7}{*}{ 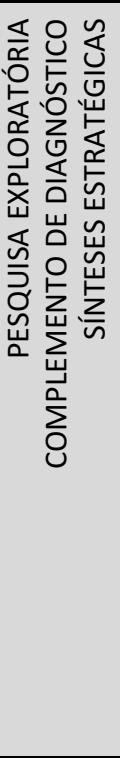 } & \multirow[t]{2}{*}{$\begin{array}{l}\text { Corroborar os padrões identificados } \\
\text { na pesquisa documental e delimitar } \\
\text { diretrizes para novas ferramentas } \\
\text { de sintaxe visual. }\end{array}$} & $\begin{array}{l}\text { Aplicação de ferramenta Mapa de Categorias Expressivas (para } \\
\text { síntese de conceito de linguagem) com alunos da 2ª série (2013); } \\
\text { Análise dos resultados e possíveis adaptações }\end{array}$ \\
\hline & & Mapa de Categorias Expressivas Definitivo \\
\hline & \multicolumn{2}{|c|}{$\begin{array}{l}\text { Agregar delimitação sistêmica e pensamento visual } \\
\text { à conceituação do projeto }\end{array}$} \\
\hline & & Identificação e Adaptação Modelo de Diseño Concurrente \\
\hline & & $\begin{array}{l}\text { Contato prévio com alunos novos - colaboração em projeto } \\
\text { interdisciplinar ( } 2^{a} \text { série - 2014); } \\
\text { Cadastro de voluntários para a experimentação teste baseada no } \\
\text { modelo de Diseño Concurrente } \\
\text { Oficinas de projeto (2 } 2^{\text {a }} 3^{a} \text { série - 2014) } \\
\text { - Focus Group (mediação semiestruturada/ amostra intencional } \\
\text { homogênea- *análise de conteúdo) } \\
\text { Análise dos resultados e possíveis adaptações }\end{array}$ \\
\hline & & Diagrama REC \\
\hline & & $\begin{array}{l}\text {-Pré-teste do Diagrama REC (*obs. Participante) } \\
\text { Análise dos resultados parciais e possíveis adaptações }\end{array}$ \\
\hline \multicolumn{3}{|c|}{ QUALIFICAÇÃO USP (Universidade de São Paulo) } \\
\hline \multirow[t]{2}{*}{ 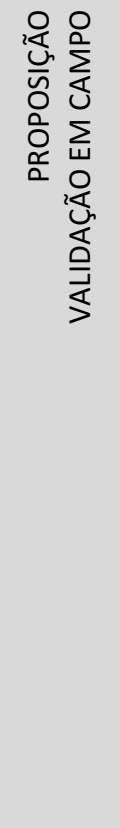 } & \multirow[t]{2}{*}{$\begin{array}{l}\text { Definir a proposta definitiva das } \\
\text { ferramentas projetuais e verificar } \\
\text { sua eficácia no universo estudado. } \\
\text { Validar o instrumental metodológico } \\
\text { proposto para aplicação na } \\
\text { formação de designers de moda. }\end{array}$} & $\begin{array}{l}\text {-Complementação das bases teóricas e planejamento de } \\
\text { estratégias de validação; } \\
\text {-planejamento compartilhado com professora da disciplina } \\
\text { Metodologia do Projeto, coordenadora do curso e professores } \\
\text { colaboradores; } \\
\text { - participação colaborativa da pesquisadora em atividade regular } \\
\text { da disciplina para aproximação e identificação de conhecimento } \\
\text { prévio - pesquisa de grupos de consumo; } \\
\text { - ponte cognitiva - atividade expressiva- vídeo; } \\
\text { - realização de prática projetual completa (da investigação de } \\
\text { contexto até a realização e teste do protótipo) com auxilio das } \\
\text { ferramentas propostas e parceria com empresa real; } \\
\text { - estudantes: auto-avaliação; registros autônomos do processo } \\
\text { projetual; } \\
\text { - professores colaboradores: auxílio interdisciplinar; avaliação de } \\
\text { processo e resultados; } \\
\text { - pesquisadora: observação participante; registros em protocolo de } \\
\text { observação e audiovisuais; coordenação das ações a partir das } \\
\text { realimentações do processo investigativo; } \\
\text { - coordenadora de colegiado: adaptações de horário semanal e } \\
\text { disponibilidade de laboratórios, conforme demandas do projeto. }\end{array}$ \\
\hline & & PROPOSTA DEFINITIVA DAS FERRAMENTAS \\
\hline
\end{tabular}

Fonte: elaborado pela autora com base na pesquisa realizada (2014)

As ações em campo foram acompanhadas pelos registros de observação participante (registro por escrito em protocolo de observação; fotos; vídeos) e os processos autônomos foram registrados pelos próprios alunos, em um "caderno de projeto". Os cadernos foram entregues ao final da atividade e constituem parte do acervo documental que auxiliou a análise dos resultados. Para esclarecimento do trajeto realizado, descrevem-se a seguir os procedimentos efetuados em cada interação. 


\subsubsection{INTERAÇÃO 1}

Aplicação da ferramenta Mapa de Categorias Expressivas, em formato de repentina (5 horas) com a segunda série do ano letivo de 2013.

Para confirmação dos procedimentos de uso do mapa de categorias expressivas, empregou-se a estratégia de observação participante em uma atividade exclusiva para o uso da ferramenta com um grupo de 2 a série. A atividade prática teve o intuito de verificar eventuais dificuldades na utilização do instrumental gráfico (mood board e tabela de elementos sensórios) que auxilia a construção do mapa.

Quadro 14 - Especificação da Primeira Interação em Campo

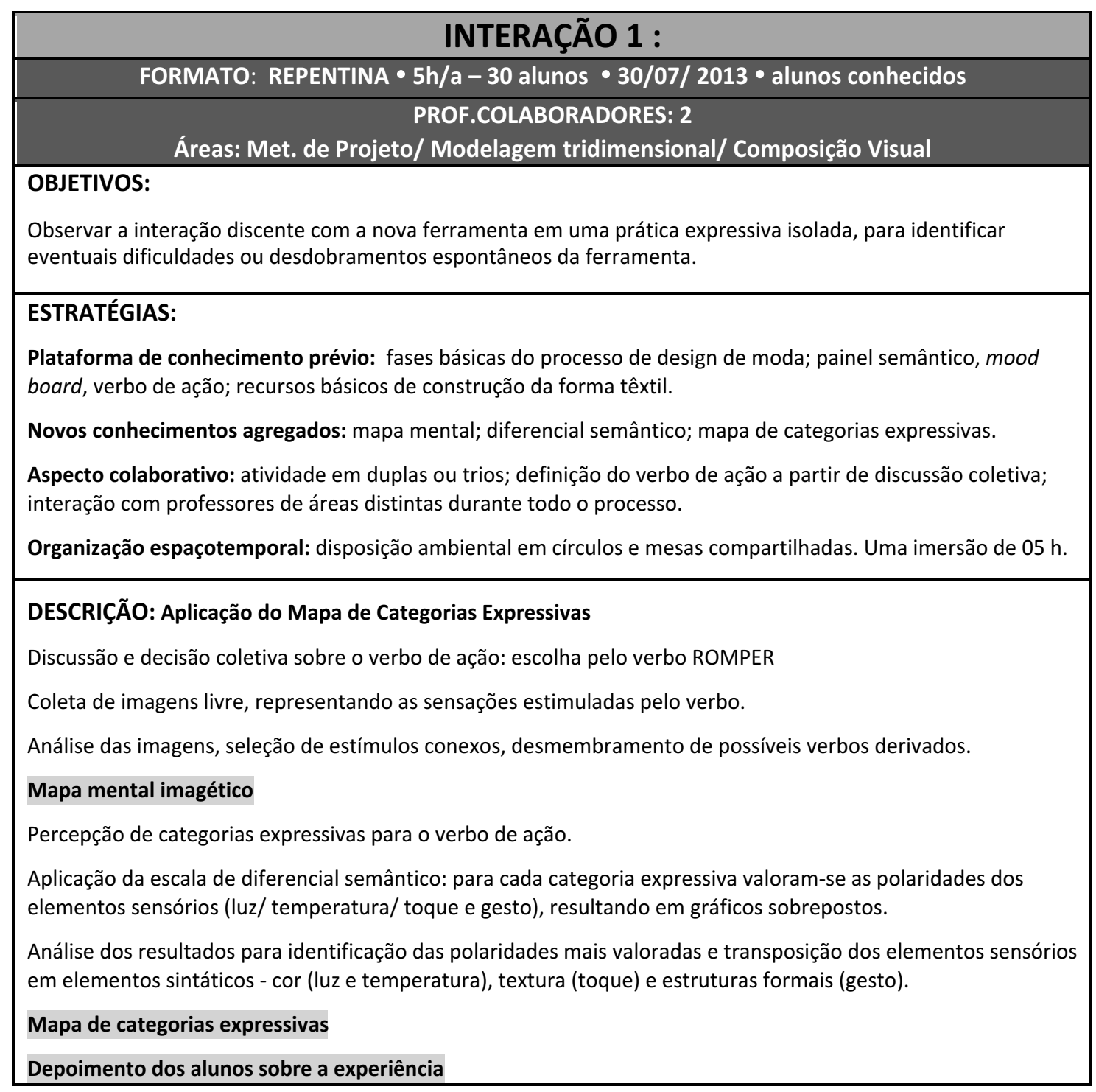

Fonte: elaborado pela autora com base na pesquisa realizada (2013) 
Figura 28 - Alunos em interação com o Mapa de Categorias Expressivas
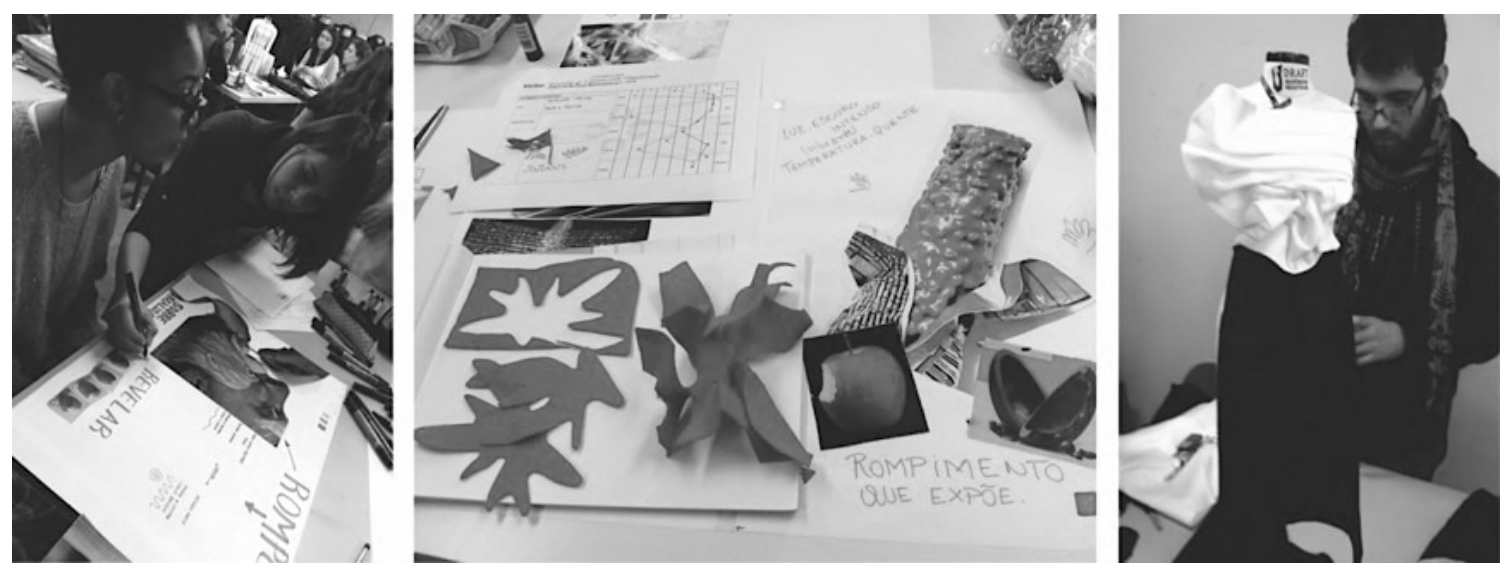

Fonte: acervo da autora (2013)

A) DESDOBRAMENTOS

- Confirmação da eficácia da ferramenta na agilidade de extração de diretrizes sintáticas, a partir da associação com os elementos sensórios.

- Observação de maior facilidade para visualizar os elementos expressivos também como elementos de estrutura e interação com o produto.

- Possibilidade de agregação da ferramenta com a fase de exploração do contexto e síntese do conceito gerador.

\subsubsection{INTERAÇÃO 2}

FASE 1: diagnóstico de dificuldades no processo projetual (Focus Group) com alunos das 2a e 3a séries do ano letivo de 2014.

FASE 2: pré-teste Diagrama REC, em formato de oficina de projeto, em atividade extraclasse com alunos voluntários, separados em dois grupos: 2a e 3 a séries.

O propósito de trabalhar em cooperação com alunos de diferentes séries foi verificar eventuais dificuldades e conferir se o entendimento do uso da ferramenta dependia de uma vivência de projeto mais extensa, uma vez que os alunos de terceira série já haviam concluído a disciplina de Metodologia Projetual e passado por dois projetos integradores, enquanto os da segunda série haviam vivenciado o primeiro 
bimestre da disciplina de Metodologia Projetual e passado por apenas um projeto integrador.

Quadro 15 - Especificação da Segunda Interação em Campo

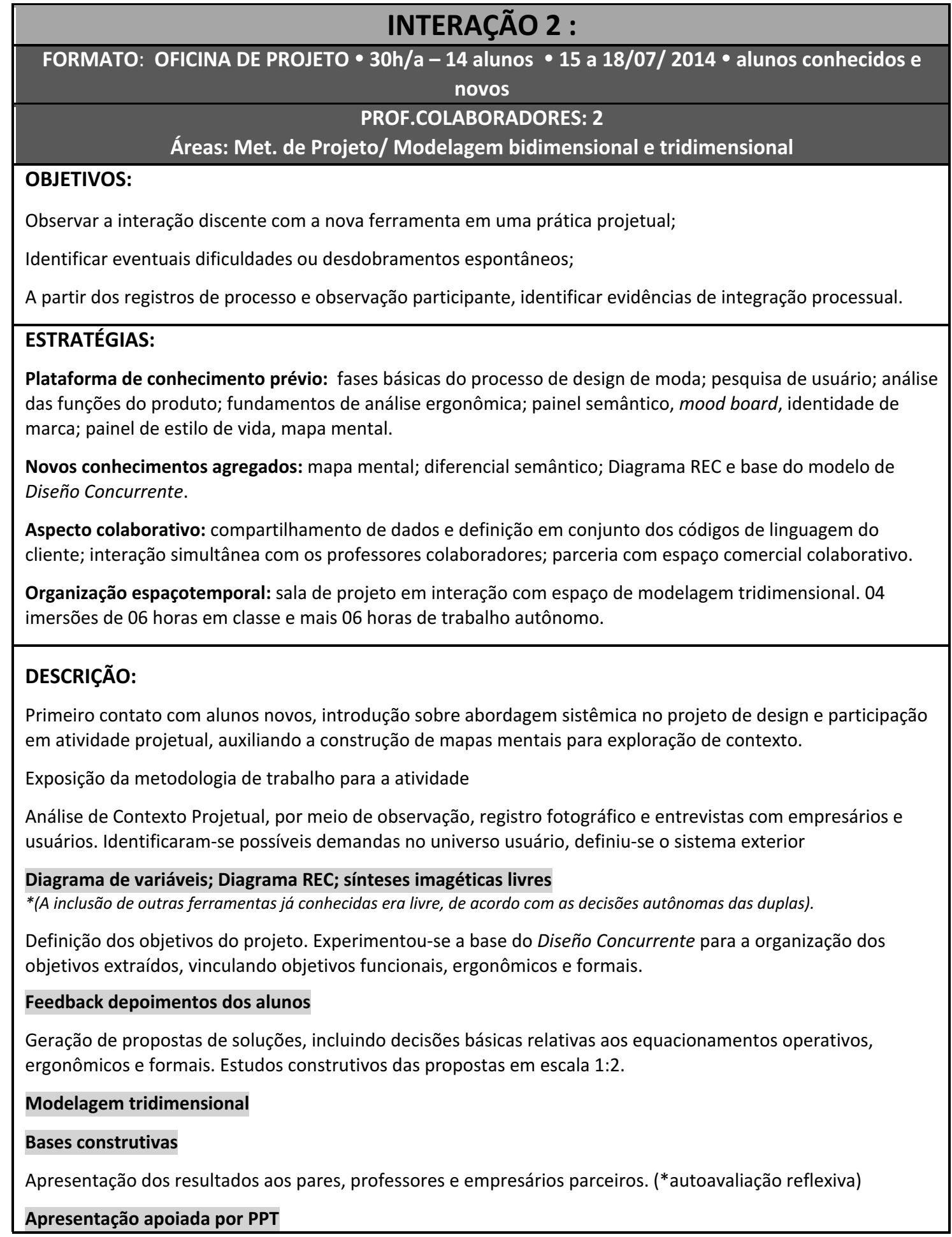

Fonte: elaborado pela autora com base na pesquisa realizada (2014) 
Figura 29 - Alunas em interação com o Diagrama REC em pré-teste
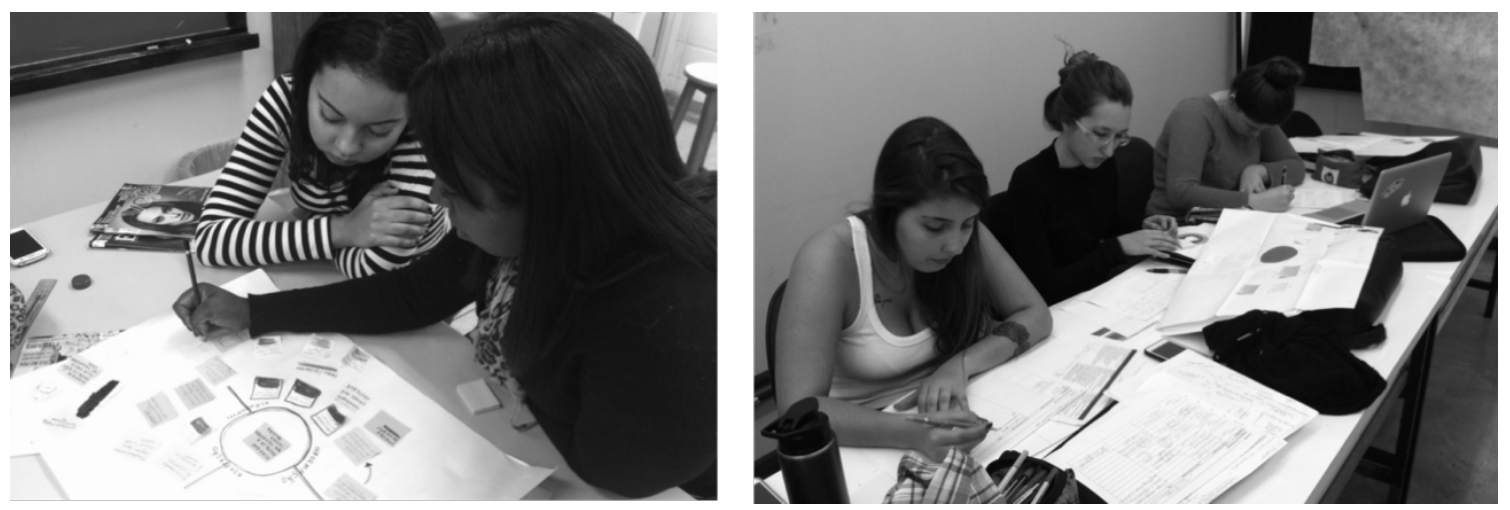

Fonte: acervo da autora (2014)

Figura 30- Experimentações de sintaxe da forma
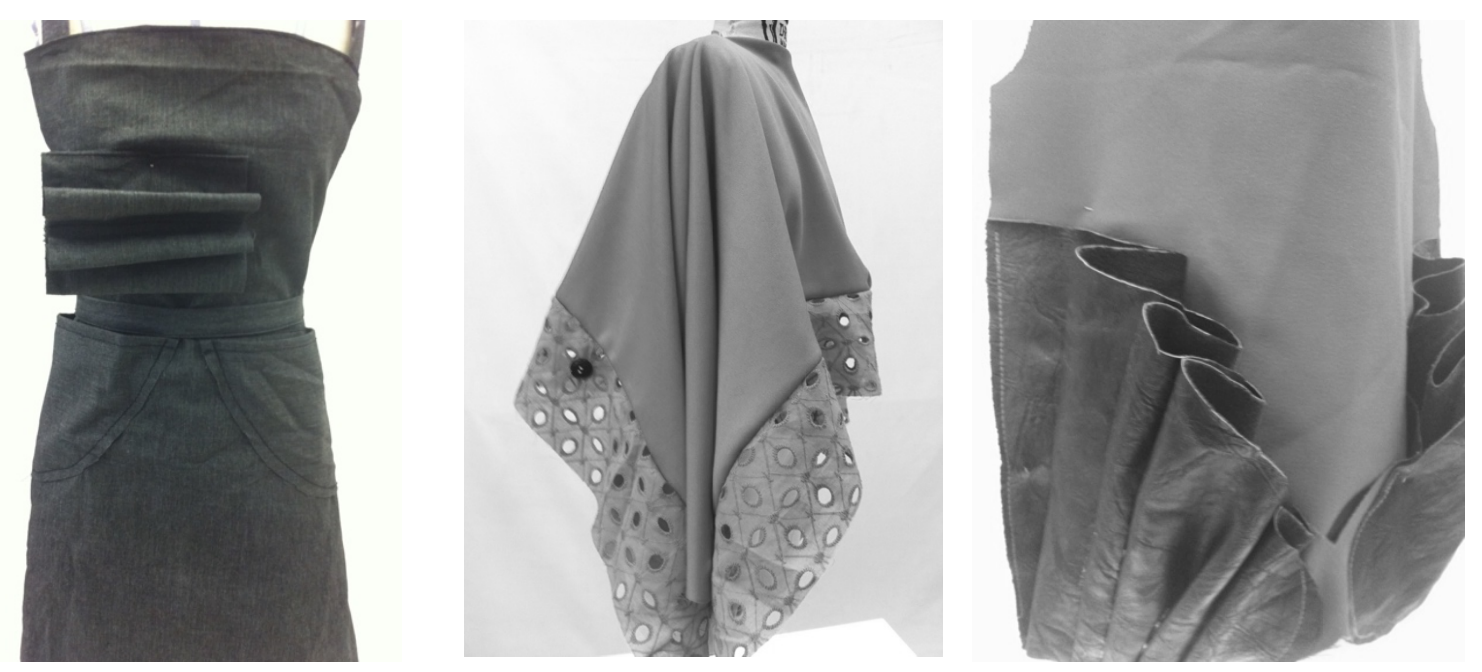

Fonte: acervo da autora (2014)

\section{B) DESDOBRAMENTOS}

- Confirmação do movimento radial no registro das informações no diagrama para as conexões dos conceitos.

- Confirmação das palavras-chave e definição da estrutura gráfica do Diagrama REC.

- Inserção de representações corporais bidimensionais como auxílio para o estudo do espaço de design.

No decorrer do processo não foram observadas ou relatadas, no grupo da segunda série, dificuldades que apontassem qualquer relação com a ausência dos conhecimentos relativos à terceira série. As dificuldades constatadas se relacionavam à 
novidade do instrumental. Principalmente, eram dúvidas sobre como lidar com a nova forma de organizar a informação. Vale ressaltar que o grupo da segunda série, que já havia demostrado maior propensão investigativa no focus group, explorou e desmembrou um maior número de vezes as representações gráficas do Diagrama REC, possibilitando uma experimentação formal mais detalhada. Isto posto, confirmou-se que a inserção da ferramenta, nas práticas projetuais preparatórias da segunda série, era adequada para aquela fase do percurso formativo.

Em relação aos desdobramentos realçados, o desenho bidimensional do corpo pode ser utilizado diretamente nas conexões do Diagrama REC ou na ficha de objetivos, de acordo com a decisão do usuário da ferramenta. A introdução deste elemento foi fundamental para a visualização do "espaço de design", uma vez que este é utilizado como base para o estudo da estrutura formal, sobrepondo esboços que assinalam áreas de cobertura corporal, estruturas volumétricas e limites espaciais para movimentação ou operacionalidade do artefato projetado.

Salienta-se que, em virtude do cunho voluntário da atividade, realizada em horário extraclasse, apenas quatorze estudantes chegaram ao final da interação com o Diagrama REC. Do grupo total, priorizou-se o enfoque na segunda série e os discentes desta série completaram a atividade com experimentações em escala 1:2 e uma apresentação para o cliente/parceiro.

\subsubsection{INTERAÇÃO 3}

FASE 1: confirmação de dificuldades específicas do grupo por meio da aplicação de questionário.

FASE 2: esta fase ocorreu em forma de atividade regular na disciplina de Metodologia do Projeto. Foi formatada como atividade prática de projeto, sendo denominada como Projeto Leveza do Ser, em referência ao nome da marca parceira. A finalidade da interação era aplicar o Diagrama REC integrado ao Mapa de Categorias Expressivas, inserindo-os na dinâmica curricular regular do ambiente estudado (90 h). 
Quadro 16 - Especificação da terceira interação em campo

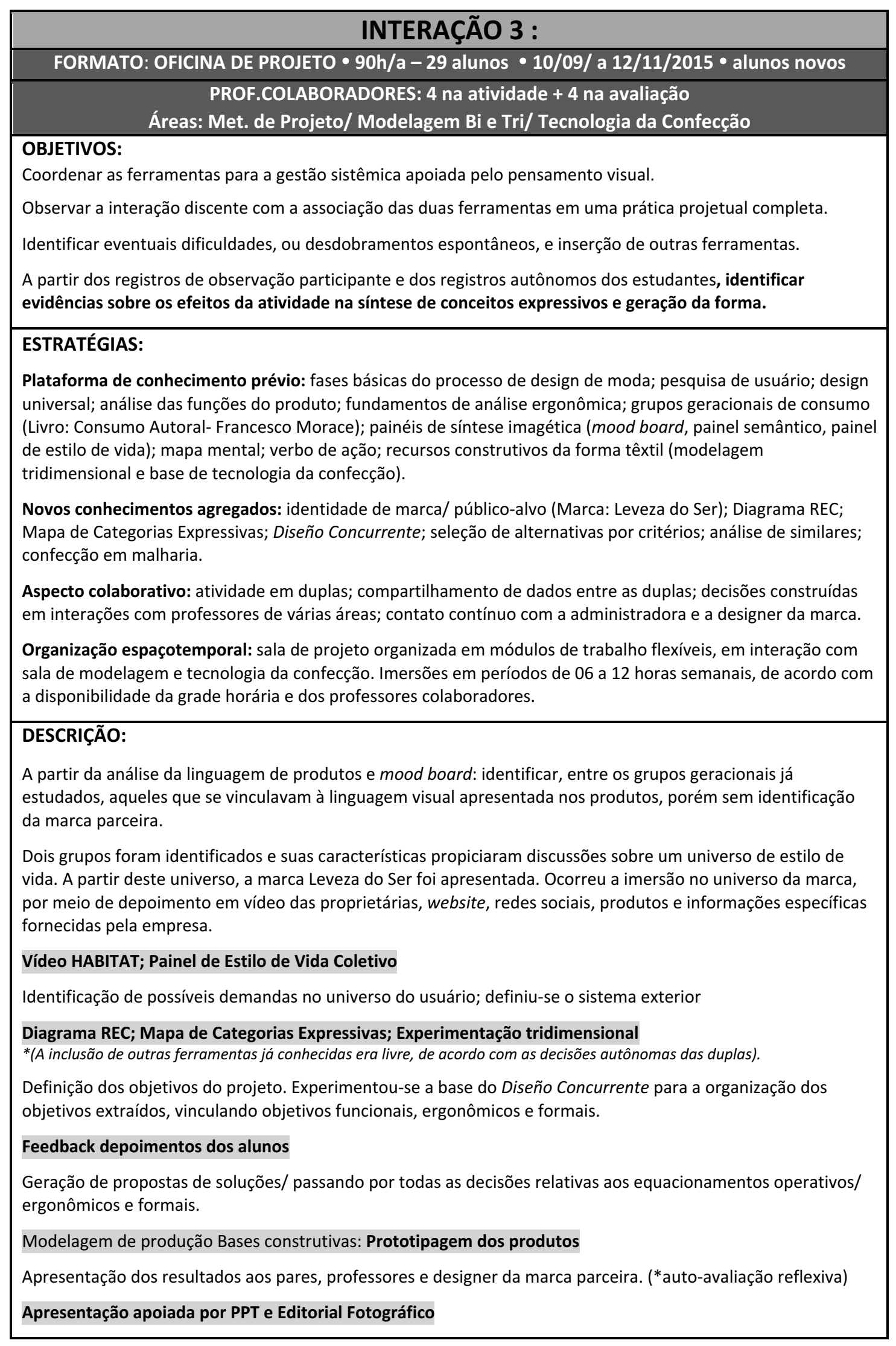

Fonte: elaborado pela autora com base na pesquisa realizada (2015) 
Figura 31 - Alunos em interação com Diagrama REC e Mapa de Categorias Expressivas coordenados
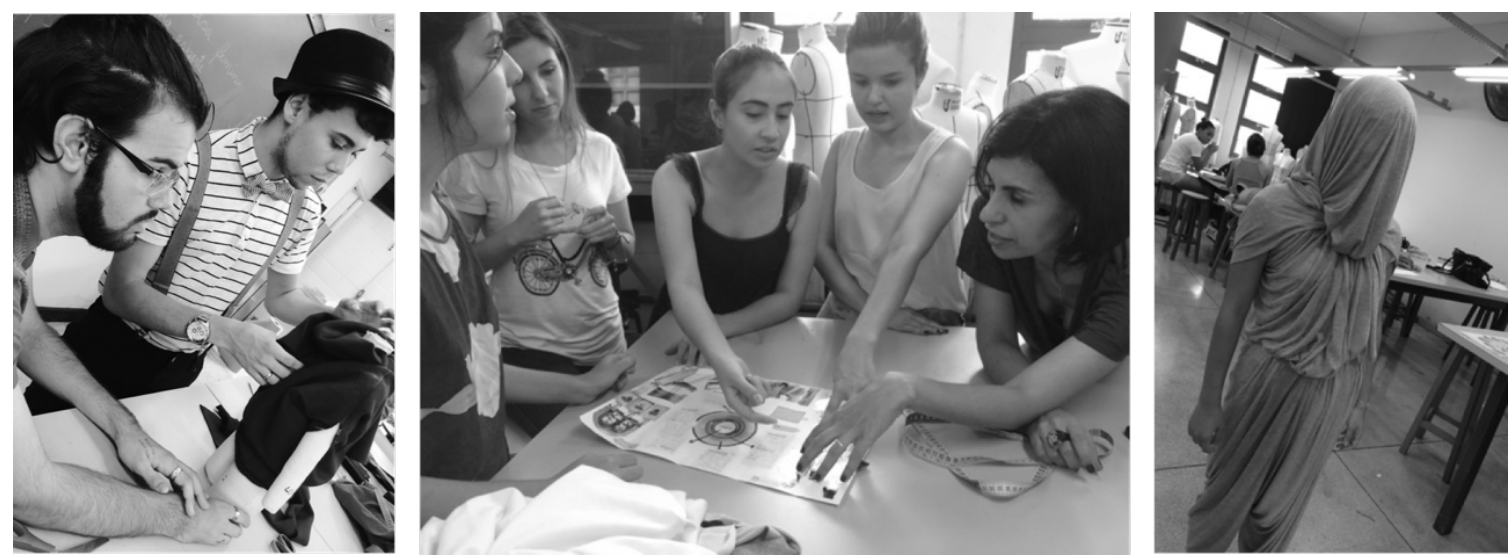

Fonte: acervo da autora (2015)

Figura 32 - Estudo do espaço de design sobre representação do corpo

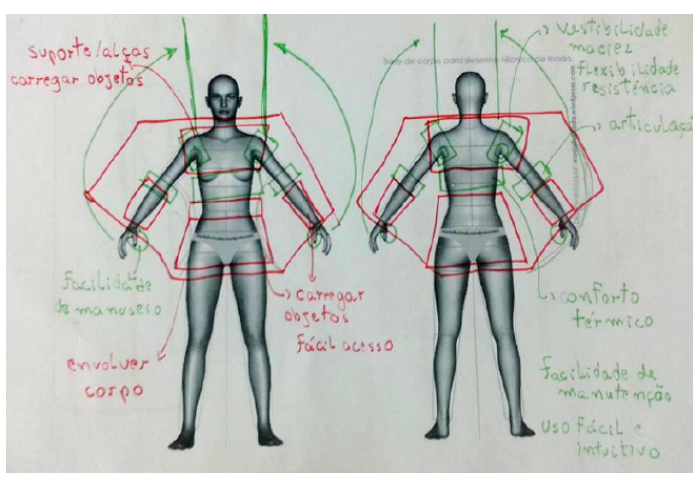

Fonte: acervo da autora (2015)

\section{C) DESDOBRAMENTOS}

- Elaboração das estruturas gráficas definitivas.

- Derivação de ferramentas complementares - diagrama de objetivos em fluxo, para auxílio da organização e registro dos objetivos e tabela de avaliação de alternativas, para seleção de propostas (APÊNDICE A).

- Confirmação da permeabilidade para inserção de outras ferramentas já conhecidas pelos alunos.

- Elaboração de ficha de avaliação de resultados, para verificação dos professores, gerada a partir da ficha de avaliação de alternativas utilizada pelos estudantes.

As ferramentas complementares foram elaboradas e introduzidas no decorrer da atividade. O resumo deste processo se apresenta na Figura 33, que ilustra as conexões das estratégias metodológicas usadas no transcurso da terceira interação. $\mathrm{Na}$ 
imagem é perceptível o movimento cíclico de realimentações entre as ferramentas, evidenciando as interações simultâneas entre as informações existentes e os novos dados assimilados pelo sistema.

Destaca-se que o diagrama de objetivos em fluxo auxilia a organização dos objetivos na ficha de objetivos, elaborada com base nos subsistemas do diseño concurrente. São ferramentas complementares, que se acoplam às duas principais, para facilitar a visualização da convergência em um foco projetual.

Figura 33 - Conexões das estratégias metodológicas na Interação 3

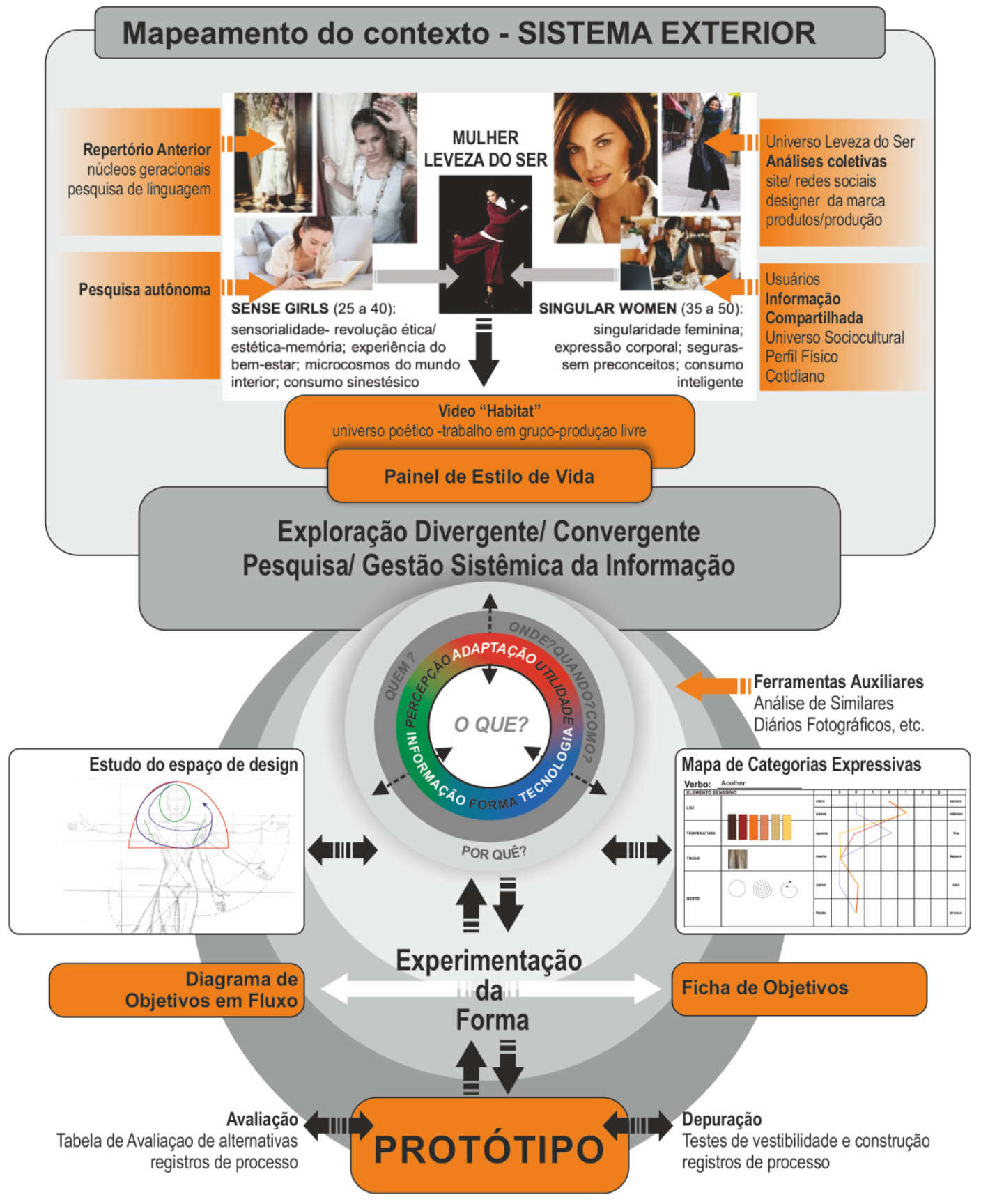

Fonte: elaborado pela autora com base na pesquisa realizada (2016) 
Na Figura 33, é possível visualizar a estrutura sobre a qual foi organizada a Interação 3. A plataforma de conhecimentos prévios serviu como âncora para definir o perfil do público-alvo da empresa parceira - Leveza do Ser -, bem como o universo poético que envolvia o conceito da marca, o qual propiciou a criação de vídeos denominados "Habitat".

A partir da apresentação dos vídeos, os estudantes analisaram e elaboraram um painel de estilo de vida, que foi construído coletivamente. As análises foram alimentadas pelas informações provenientes das pesquisas autônomas de cada dupla e compartilhadas em sala. O compartilhamento de informações e análises estimulou as discussões de cada dupla, provocando a exploração divergente do contexto estudado. Tal conduta facilitou a inserção de informações no Diagrama REC, a definição do sistema exterior e a delimitação projetual de cada equipe.

A gestão da informação, amparada pelo Diagrama REC, foi orientada e assessorada no trajeto projetual, mas as decisões sobre as informações inseridas e a forma gráfica de registrá-las foi decidida livremente por cada equipe. Igualmente, os ciclos de retroalimentação, as alterações de percurso e o momento de inserir as ferramentas complementares, também foi decidido pelas duplas, conforme indicavam as discussões particulares ou em conjunto com os professores.

O Mapa de Categorias Expressivas foi utilizado por todas as equipes, assim como a ficha de objetivos - ou o Diagrama de Objetivos em Fluxo, contudo o momento de empregá-los também respeitou o ritmo de cada equipe. Do mesmo modo, todos usaram as representações sobre o corpo e as experimentações tridimensionais sobre o manequim. Isto auxiliou o estudo do espaço de design, facilitando a integração dos objetivos ergonômicos, funcionais e formais na sintaxe da forma.

A atividade foi finalizada com a confecção de protótipos, registro fotográfico (editorial) do produto em uso, apresentação verbal - pares, professores e designer da marca - e feedback do processo. 


\section{CAPÍTULO 7}

Sobre Resultadose Conexó

Sobre Resultados e Conexões Futuras 


\section{RESULTADOS E CONCLUSÕES}

Este capítulo apresenta os resultados projetuais, a síntese das observações em campo e a avaliação das ocorrências relacionadas à utilização do instrumental proposto.

A trajetória avaliativa do estudo relaciona os registros de observação participante, a autoavaliação dos estudantes e a avaliação dos pares (professores colaboradores do Curso de Design de Moda da UEL), agregando uma avaliação quantitativa dos resultados e outra qualitativa de processos, efetivada por focus group. Para validação efetiva do instrumental, os dados foram triangulados, em busca da identificação de concordâncias, ou divergências, entre as observações da presente pesquisadora, a percepção dos alunos e a visão especializada dos professores colaboradores.

\subsection{RESULTADOS PROJETUAIS}

Mesmo que esta pesquisa tenha o enfoque direcionado ao processo e não ao produto, não torna menos relevante expor as soluções projetuais obtidas com as intervenções em sala de aula. Pressupondo que um bom resultado depende, em grande parte, da qualidade da gestão do processo, o tópico mostra alguns exemplos do trajeto projetual dos estudantes, incorporando o Mapa de Categorias Expressivas e o Diagrama REC.

O propósito dos exemplos é proporcionar uma percepção geral do uso das ferramentas e não a leitura detalhada de cada informação registrada no Diagrama REC, uma vez que os objetivos, também inclusos na imagem, oferecem uma síntese do raciocínio que a ferramenta gerou. Assim, pretende-se que, ao visualizar os objetivos em conjunto com as sínteses expressivas, se observem as relações que guiaram a sintaxe da forma no produto final.

Os exemplos escolhidos foram os trabalhos eleitos pela marca parceira como resultados passíveis de entrar em linha de produção. Os dois primeiros já foram produzidos e o terceiro entrará na próxima coleção. Vale enfatizar que a escolha da empresa se deu pelos seguintes critérios: qualidade do pensamento projetual; facilidade 
produtiva, de acordo com as possibilidades disponíveis da empresa, que terceiriza toda a produção; interação estética com a coleção vigente da marca.

\section{EXEMPLO 1}

Figura 34 - Exemplo 1: documentação de projeto- Mapa de Categorias Expressivas e Diagrama REC

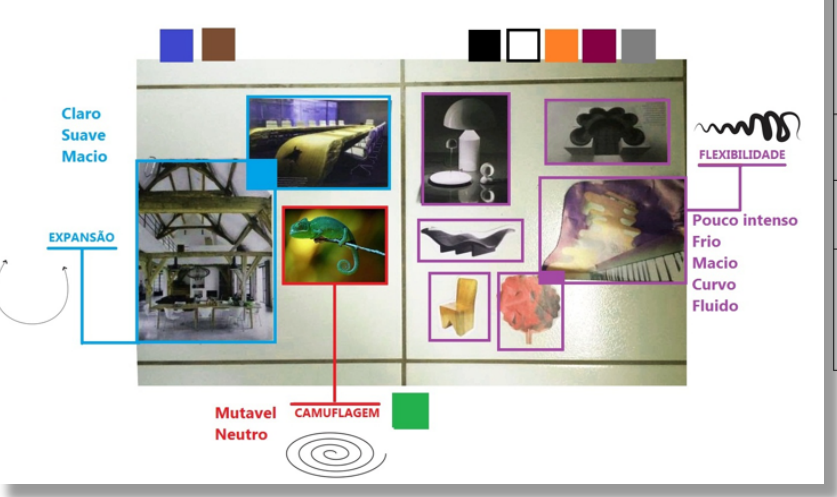

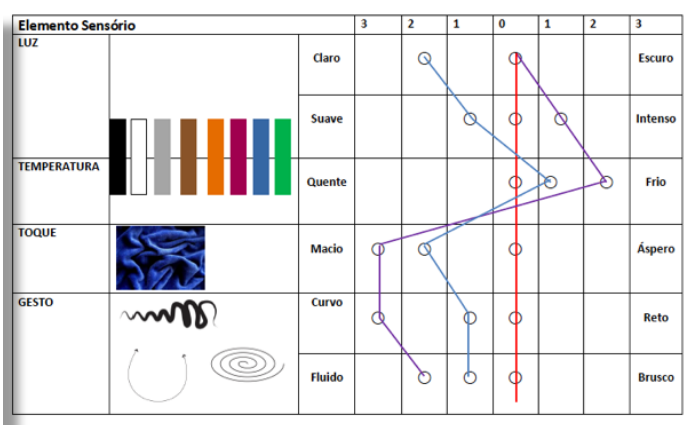

MAPA DE CATEGORIAS EXPRESSIVAS

verbo de ação: adaptar

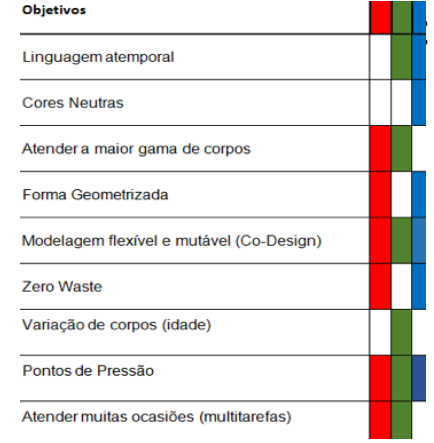

DIAGRAMA REC

definição dos objetivos identificados pelo código cromático dos subsistemas fundamentais

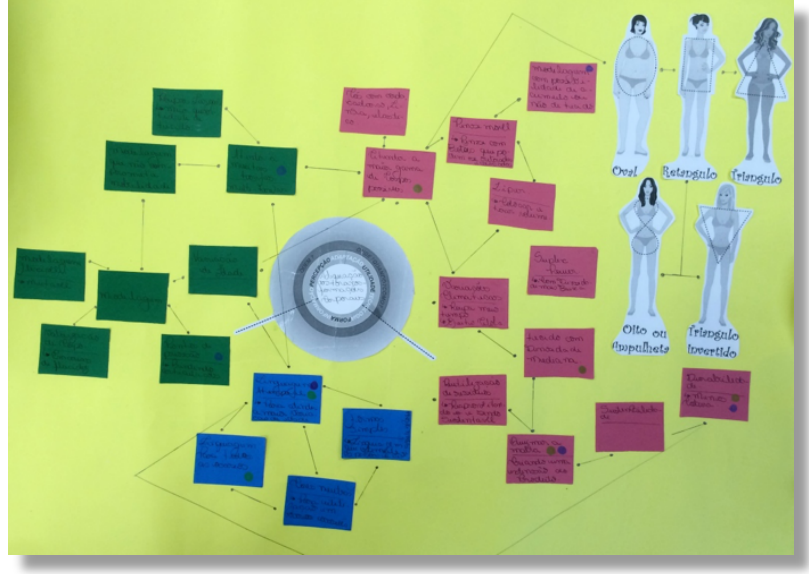

Fonte: acervo da autora (2015) - Autores do projeto: Jônatas Delmonaco e Pedro Henrique Pereira

Figura 35 - Exemplo 1: estudos de sintaxe da forma em interação corporal
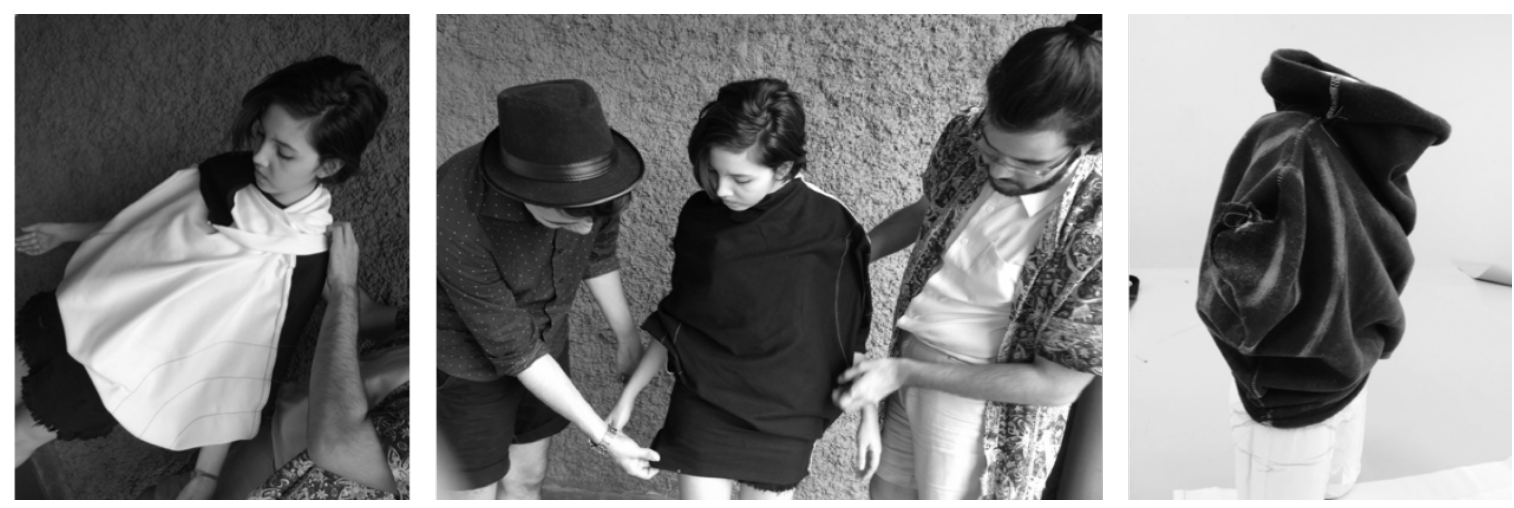

Fonte: acervo da autora (2015) - Autores do Projeto: Jônatas Delmonaco e Pedro Henrique Pereira 
Figura 36 - Exemplo 1: protótipo do Acommodare e produto final produzido pela marca parceira
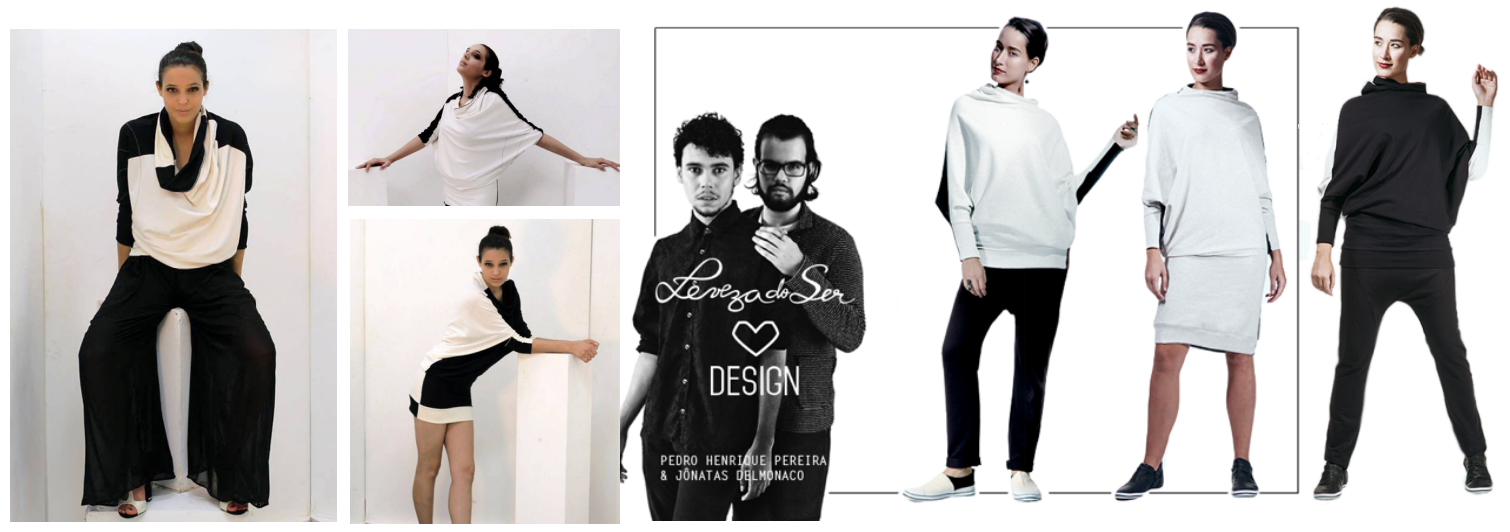

Fontes: acervo dos autores do projeto e acervo da marca Leveza de Ser (2016)

De forma geral, as propostas finais evidenciaram ótimos resultados e o trajeto contou com observações surpreendentes no uso das ferramentas. Assim, a seleção dos trabalhos premiados, como opções de exemplos ilustrativos, foi determinada por demonstrar caminhos projetuais que se estenderam até a produção seriada.

\section{EXEMPLO 2}

Figura 37-Exemplo 2: documentação de projeto - Mapa de Categorias Expressivas e Diagrama REC
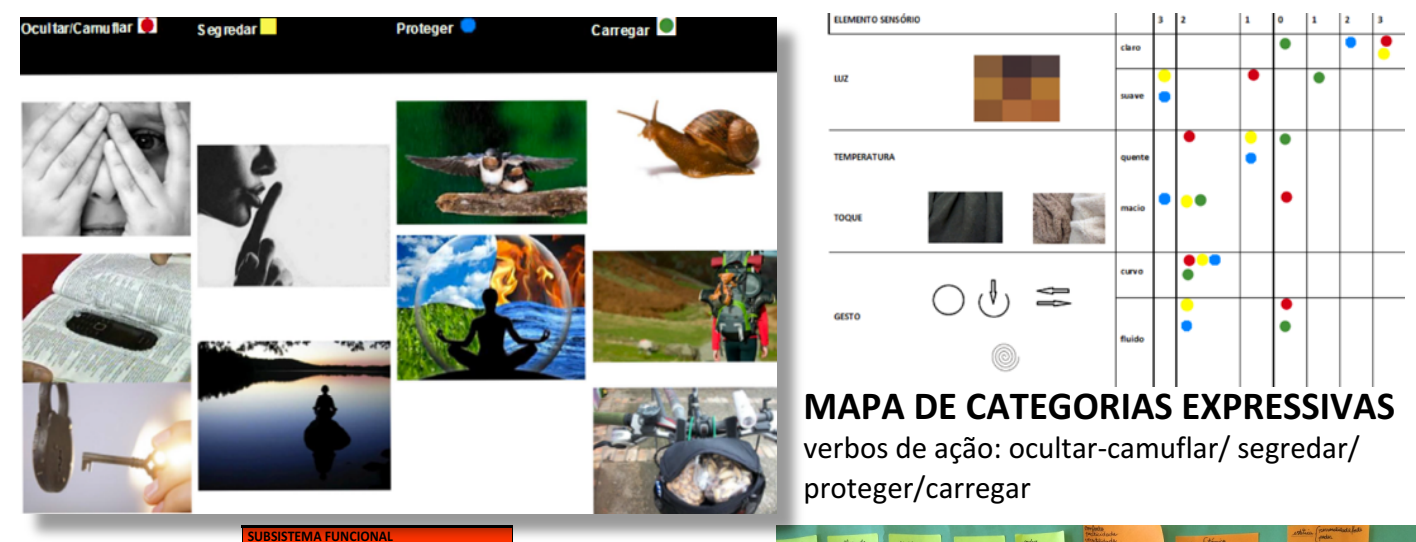

\section{MAPA DE CATEGORIAS EXPRESSIVAS}

verbos de ação: ocultar-camuflar/ segredar/ proteger/carregar
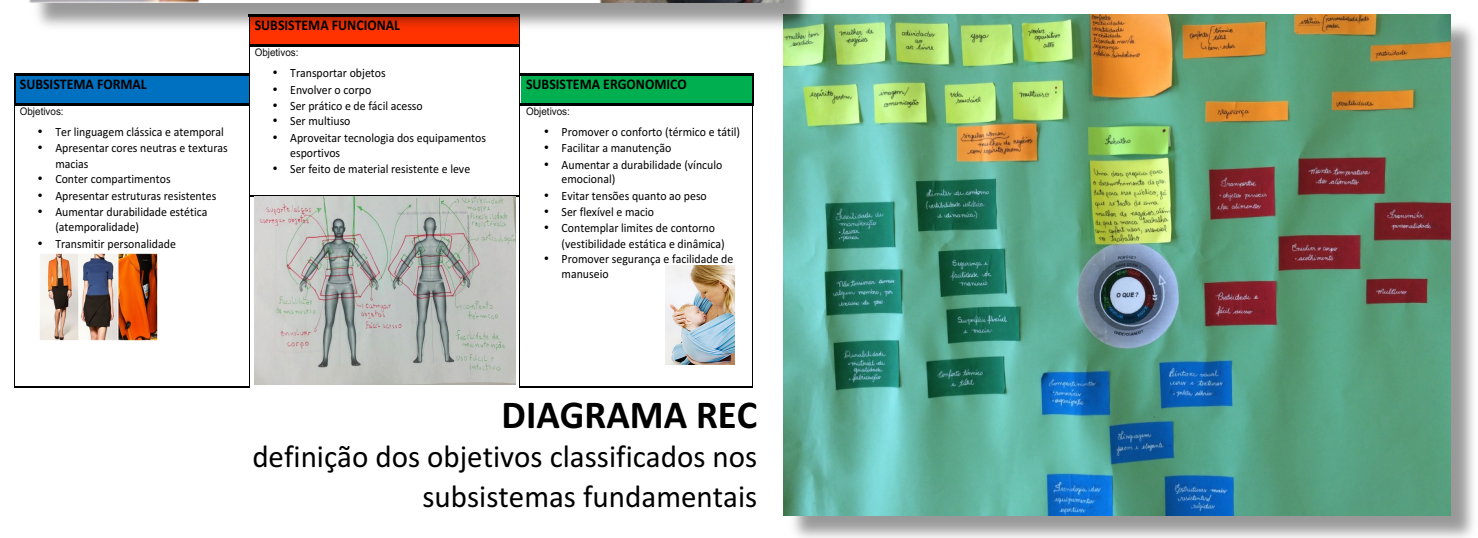

Fonte: acervo da autora (2015) - Autoras do projeto: Amanda Pilla e Isabella Beraldo 
Figura 38 - Exemplo 2: estudos do "espaço de design" sobre o corpo e comportamento de materiais
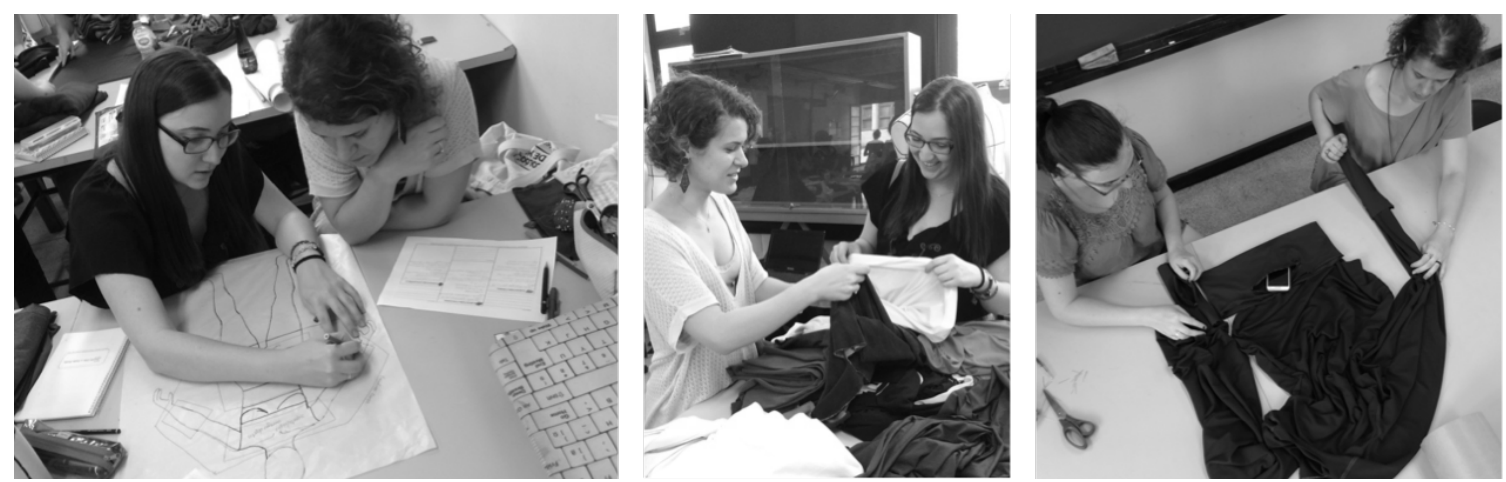

Fonte: acervo da autora (2015) - Autoras do projeto: Amada Pilla e Isabella Beraldo

Figura 39 - Exemplo 2: produto final produzido pela marca parceira e protótipo da Blusa Transportadora
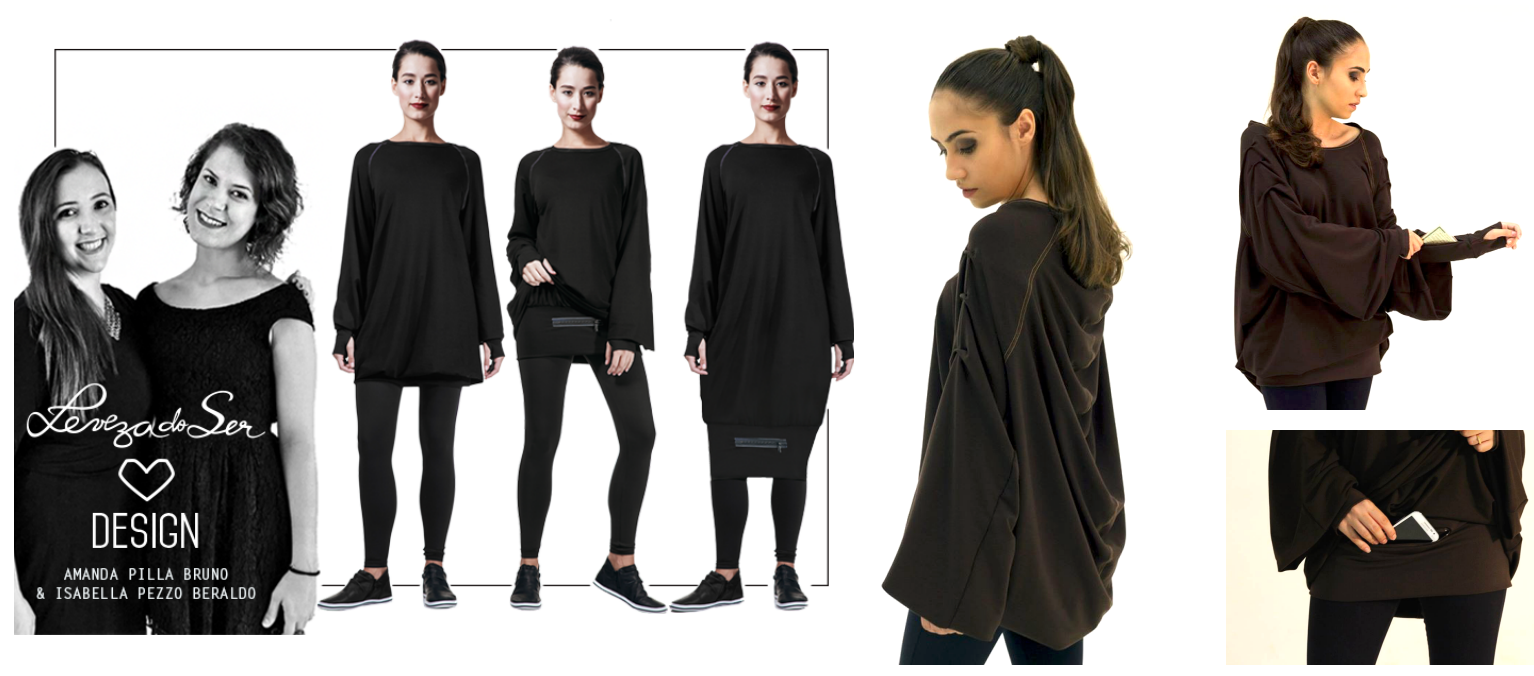

Fontes: acervo das autoras do projeto e acervo da marca Leveza do Ser (2016)

\section{EXEMPLO 3}

Figura 40 - Exemplo 3: registros do processo de evolução da sintaxe da forma
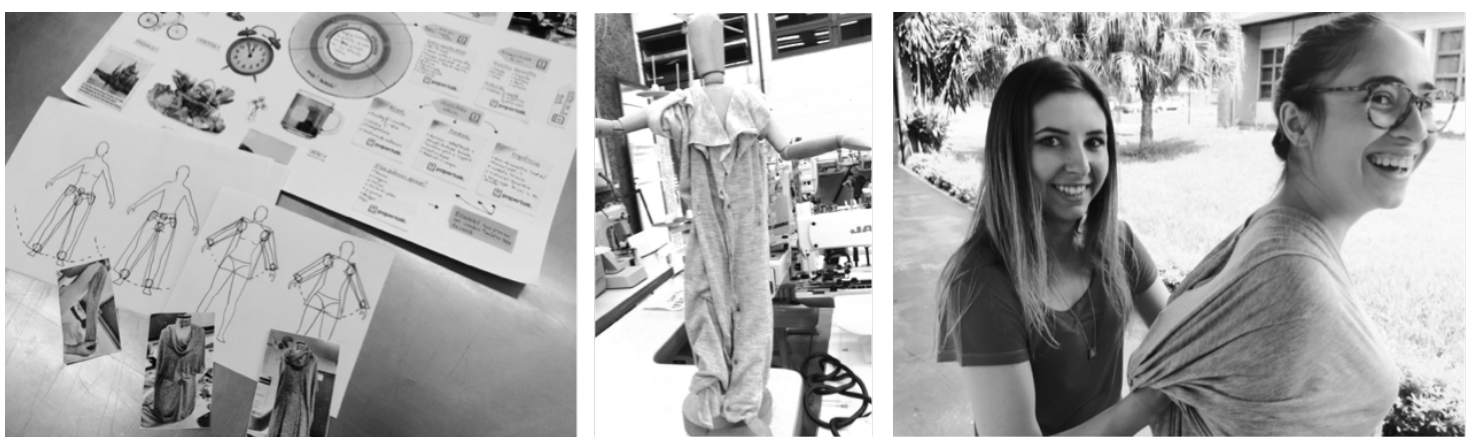

Fonte: acervo da autora (2015) - Autoras do projeto: Izabel Aguilar e Milena Garcia Pinto 
Figura 41 - Exemplo 3: documentação de projeto - Mapa de Categorias Expressivas e Diagrama REC

\begin{tabular}{|c|c|c|c|c|c|c|c|c|}
\hline & 3 & 2 & 1 & 0 & 1 & 2 & 3 & \\
\hline claro & & & 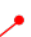 & & , & & & escuro \\
\hline suave & & & & . & & & & intenso \\
\hline quente & 8 & & & & & & & frio \\
\hline macio & & & & & & & & áspero \\
\hline curvo & & & & & & & & reto \\
\hline fluido & 16 & & & & & & & brusco \\
\hline
\end{tabular}

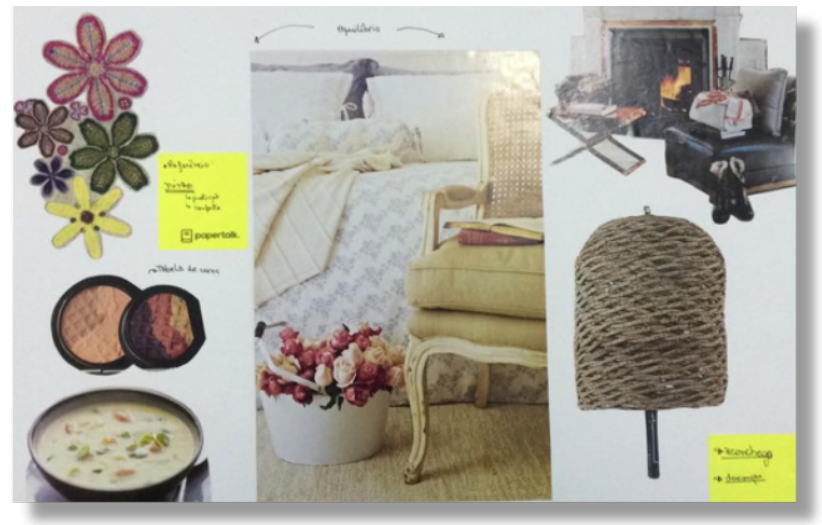

MAPA DE CATEGORIAS EXPRESSIVAS

verbos de ação: descansar/ aconchegar $~$ NINHO VESTíVEL

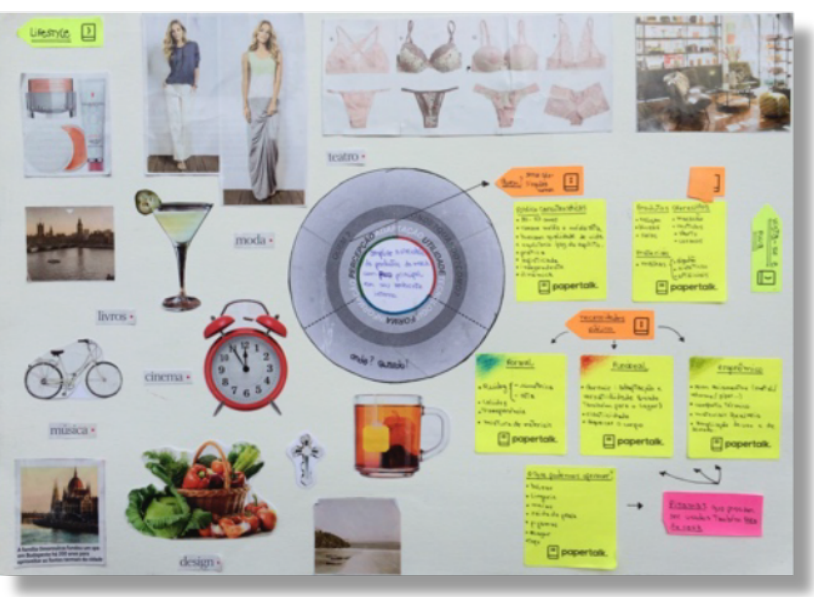

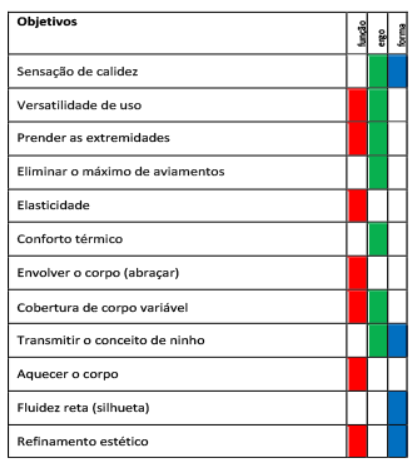

DIAGRAMA REC

definição dos objetivos identificados pelo código cromático dos subsistemas fundamentais

Fonte: acervo da autora (2015) - Autoras do projeto: Izabel Aguilar e Milena Garcia Pinto
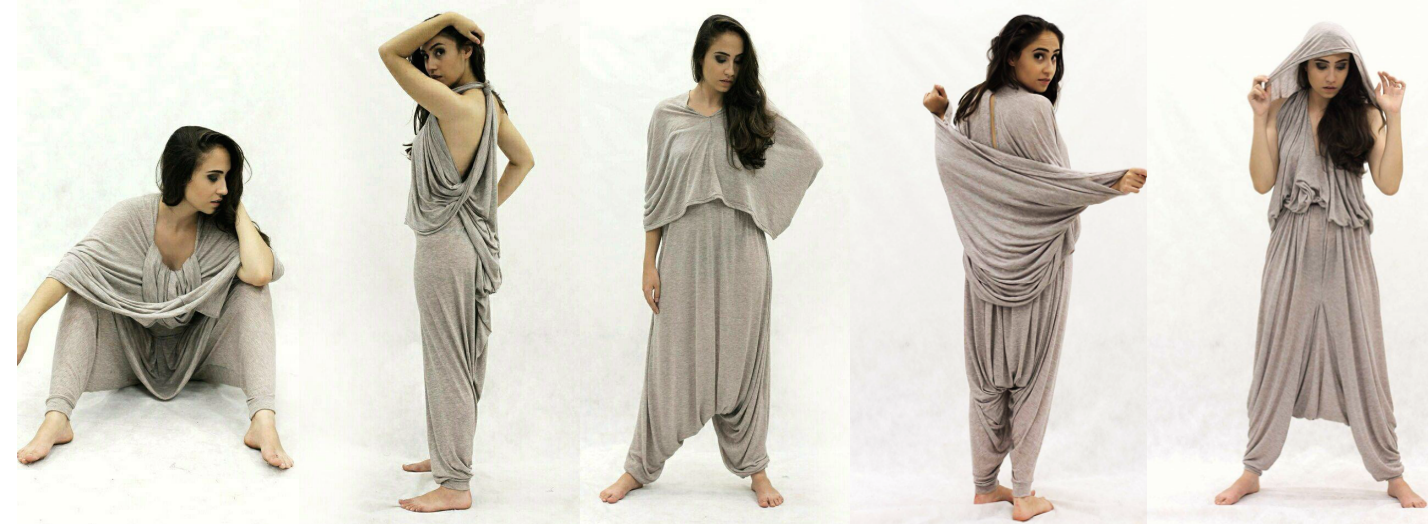

Fonte: acervo das autoras do projeto (2015) 
Os protótipos foram inteiramente confeccionados pelos estudantes. O processo contou com diversas experimentações de modelagem e detalhes construtivos, pois o intuito consistia em ampliar o conhecimento de modelagem/construção, incentivar a investigação prática como fonte de depuração dos objetivos de projeto e estimular a sintaxe da forma integrada à estrutura corporal. Por isso, ainda que houvesse algumas imperfeições produtivas, devido à inexperiência com o tipo de material usado pela empresa (malha), os resultados priorizavam o estudo formal e não a qualidade de acabamento.

Em relação ao processo de sintaxe visual, todos os grupos mostraram coerência com os códigos expressivos delimitados e mantiveram os objetivos operacionais e ergonômicos conectados aos estudos estéticos da forma. Mesmo os grupos que tiveram empecilhos na confecção, interferindo no resultado formal pretendido, mostraram maturidade nas análises de autocrítica, quando resgataram os objetivos durante as apresentações do projeto. De qualquer forma, com base na experiência docente neste mesmo ambiente acadêmico, seguramente o nível de coerência e complexidade das propostas projetuais foi bastante elevado para a segunda série.

Visando à confirmação dos aportes do instrumental proposto nestes efeitos observados, realizou-se uma busca por evidências positivas relevantes na sua utilização. Nesta direção, são apresentados a seguir os dados resultantes desta busca.

\subsection{OBSERVAÇÃO PARTICIPANTE}

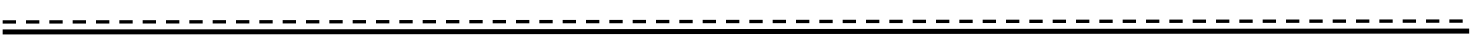

Convém lembrar que a investigação-ação possui essência autoavaliativa, ou seja, as ações introduzidas são, constantemente, avaliadas no transcurso da intervenção. As constatações deste monitoramento orientam novas ações ou, se necessário, redefinições de conduta. Isto beneficia o próprio processo investigativo, visto que a fase precedente indica rumos para a fase posterior, bem como as fases finais aprimoram os resultados encontrados nas fases iniciais.

Desta perspectiva, o registro das observações teve o propósito de auxiliar eventuais redirecionamentos das interações e reunir dados para conduzir a avaliação posterior da eficácia do instrumental proposto. 
Seguindo as recomendações de Moreira e Caleffe (2008), utilizou-se um protocolo de observação participante (APÊNDICE B) para registrar as observações a cada encontro com os estudantes. O modelo de documento contou com dois campos separados: para anotações relativas à descrição das atividades; para notas reflexivas, que continham percepções de processos ou inferências resumidas.

As anotações de campo foram compostas por notas condensadas, tomadas imediatamente ao final de cada sessão de trabalho com os estudantes, sendo ampliadas em momento posterior, com ajuda das gravações em vídeo e fotografias. Ao final do projeto, a síntese das observações em campo foi complementada pela apreciação dos cadernos de projeto, usados pelos grupos para registrar os percursos durante a atividade.

A partir dos direcionadores de atuação em campo, que enfatizavam ações para facilitar a delimitação projetual e a síntese de diretrizes sintático-semânticas, dirigiu-se o foco das observações aos comportamentos relacionados a estes aspectos. Por isso, foram priorizadas as evidências de uma condução sistêmica da gestão das informações e de alterações nos procedimentos de direcionamento expressivo e geração da forma, como apresentado no Quadro 17.

Quadro 17 - Síntese das observações em campo

\begin{tabular}{|c|c|c|}
\hline Foco de observação & Conceito Guia & Evidências observadas \\
\hline \multirow{4}{*}{ GESTÃO SISTÊMICA: } & $\begin{array}{l}\text { INTERDEPENDÊNCIA } \\
\text { INTERAÇÃOO }\end{array}$ & $\begin{array}{l}\text { Graficamente: interações simultâneas das informações } \\
\text { (verbais e imagéticas); discussões em grupo: vinculam } \\
\text { aspectos multidimensionais (forma, função e ergonomia) - } \\
\text { visão panorâmica; usam as conexões do DREC e do MCE } \\
\text { para discutir e decidir; integração espontânea: busca de } \\
\text { interação com outros professores por decisão própria. }\end{array}$ \\
\hline & $\begin{array}{l}\text { PERMEABILIDADE E } \\
\text { FLEXIBILIDADE }\end{array}$ & $\begin{array}{l}\text { Realimentação frequente da pesquisa, do DREC e do MCE; } \\
\text { registros gráficos livres; inserções autônomas de } \\
\text { estratégias projetuais complementares; DREC reutilizado } \\
\text { em sucessivas reorganizações gráficas; reajustes na } \\
\text { delimitação projetual, acoplando novos conhecimentos. }\end{array}$ \\
\hline & $\begin{array}{l}\text { DIVERGÊNCIA } \\
\text { CONVERGÊNCIA }\end{array}$ & $\begin{array}{l}\text { Ramificação das informações ampliadas pelas discussões } \\
\text { em grupo, apoiadas pela visualização panorâmica; algumas } \\
\text { dificuldades na primeira tentativa de preencher a tabela } \\
\text { de objetivos, com a base do diseño concurrente; objetivos } \\
\text { mais focados à medida que se visualizavam as primeiras } \\
\text { experimentações; percepção de lacunas de informação ao } \\
\text { visualizar as conexões no DREC. }\end{array}$ \\
\hline & $\begin{array}{l}\text { PENSAMENTO } \\
\text { CÍCLICO } \\
\text { (análise/síntese/ } \\
\text { avaliação) }\end{array}$ & $\begin{array}{l}\text { Retorno à delimitação como base para analisar a geração } \\
\text { de ideias e apresentar os resultados; verificações } \\
\text { constantes da conexão dos objetivos nos subsistemas e } \\
\text { destes com as propostas geradas. }\end{array}$ \\
\hline
\end{tabular}




\begin{tabular}{|c|c|c|}
\hline \multirow{4}{*}{$\begin{array}{l}\text { DIRECIONAMENTO } \\
\text { EXPRESSIVO: }\end{array}$} & $\begin{array}{l}\text { CÓDIGOS } \\
\text { SINTAXE/SEMÂNTICA }\end{array}$ & $\begin{array}{l}\text { MCE como ferramenta de comunicação intergrupal e com } \\
\text { os professores para tomada de decisões acerca de códigos } \\
\text { simbólicos na forma; dimensão sintática conectada aos } \\
\text { códigos semânticos extraídos do contexto. }\end{array}$ \\
\hline & \multirow{2}{*}{$\begin{array}{l}\text { DELIMITADORES } \\
\text { REFERÊNCIAS } \\
\text { CONCEITO GERADOR }\end{array}$} & $\begin{array}{l}\text { Princípios sintáticos extraídos das referências estendidos da } \\
\text { aplicação na superfície estética até a estrutura } \\
\text { construtiva; retroalimentação da delimitação gerou } \\
\text { depuração da forma. }\end{array}$ \\
\hline & & $\begin{array}{l}\text { Argumentos que vinculavam aspectos comunicativos e de } \\
\text { adaptação corporal na sintaxe da forma; verbo de ação } \\
\text { (MCE) aparentemente auxiliou a definição do conceito do } \\
\text { artefato. }\end{array}$ \\
\hline & $\begin{array}{l}\text { SÍNTESE } \\
\text { REPRESENTAÇÃO }\end{array}$ & $\begin{array}{l}\text { Agilidade na expressão imagética e extração de princípios } \\
\text { sintáticos do MCE. }\end{array}$ \\
\hline \multirow{4}{*}{ GERAÇÃO DA FORMA: } & $\begin{array}{l}\text { EXPLORAÇÃO } \\
\text { DIVERGENTE }\end{array}$ & $\begin{array}{l}\text { Exploração diversificada de interações formais } \\
\text { experimentada por todos os grupos; pesquisa prática } \\
\text { (construção e composição de materiais) inserida como } \\
\text { informação para delimitação; elementos sensórios (luz, } \\
\text { temperatura, toque e gesto) do MCE, como ponte cognitiva } \\
\text { entre síntese imagética e princípios de sintaxe, } \\
\text { aparentemente impulsionaram a geração da forma. }\end{array}$ \\
\hline & \multirow[b]{2}{*}{$\begin{array}{l}\text { SINTAXE } \\
\text { VISUAL/FORMAL }\end{array}$} & $\begin{array}{l}\text { Delimitação projetual (integrada ao MCE) mostrou diretrizes } \\
\text { precisas para a composição do suporte visual. }\end{array}$ \\
\hline & & $\begin{array}{l}\text { Experimentação tridimensional inserida naturalmente no } \\
\text { processo de delimitação por cada grupo; discussões } \\
\text { vinculando efeito estético e conforto, na geração da forma } \\
\text { - raciocínio de sintaxe integrador. }\end{array}$ \\
\hline & $\begin{array}{l}\text { INTERFACE } \\
\text { CORPO/CONTEXTO }\end{array}$ & $\begin{array}{l}\text { Inserção da representação do corpo nas ferramentas bem } \\
\text { recebida pelos alunos -visualização de conexões entre } \\
\text { objetivos. }\end{array}$ \\
\hline
\end{tabular}

Fonte: elaborado pela autora com base na pesquisa realizada (2015)

Com o apoio das bases teóricas, as observações foram organizadas sob conceitos guias. A síntese gerada proporcionou a identificação de recorrências, em que se detectam efeitos relevantes nas habilidades de formular, representar e movimentar-se (LAWSON, 2011). Estas habilidades se vinculam estreitamente às ações projetuais de delimitar e gerar, nas quais foi possível averiguar pontos críticos na etapa de diagnóstico. Logo, pode-se interpretar que a intervenção em campo apresentou um saldo de transformações positivas no ambiente pedagógico.

Cabe destacar alguns pontos observados em relação aos comportamentos relativos à aprendizagem: demonstração de compromisso e manifestações de entusiasmo com o próprio trabalho; transferência de conhecimentos prévios para aplicações em novas situações; evolução crescente da autonomia para tomada de decisões e para a busca de informações.

Em relação à dinâmica em sala de aula, quando o espaço físico foi organizado em células de interação, com distintas classes de informações (amostras de materiais; 
informação de moda e universo conceitual da marca parceira; amostras de representações corporais; espaço de interações com professores de distintas áreas), observou-se grande disposição de trabalho e alta produtividade nas discussões.

Se for considerado que este formato favorece a variedade de ritmos individuais e a possibilidade de retroalimentação imediata da investigação projetual, pressupõe-se que este sistema de espaços interativos facilitou a assimilação de novos conhecimentos à estrutura cognitiva existente. Anastasiou e Alves (2012c) corroboram que, quando a ênfase é criar um espaço de construção e reconstrução do conhecimento, pode-se lançar mão de inúmeros recursos para proporcionar experiências diversificadas, em um movimento de reconstrução individual e coletiva.

Com os ciclos da investigação-ação, os registros de observação ajudaram a planejar ações específicas para sanar as fragilidades identificadas no percurso. Nesta direção, as dificuldades observadas em alguns grupos, em relação ao uso da ficha de objetivos, foram supridas com uma alternativa de organização gráfica denominada Diagrama de Objetivos em Fluxo. Igualmente, a inserção da representação corpórea facilitou o estudo do "espaço de design".

Para garantir a autonomia das ferramentas como efetivas facilitadoras do processo projetual, decidiu-se acrescentar uma aplicação sem a presença desta pesquisadora. A aplicação sobressalente ocorreu com o mesmo grupo, no projeto integrador (PI), que ocorreu imediatamente após o projeto Leveza do Ser.

A título de comprovação dos efeitos positivos observados, ou da indicação de fragilidades e melhorias, bem como de objetividade das inferências qualitativas desta pesquisa, foi imprescindível agregar as percepções dos sujeitos participantes (estudantes e professores colaboradores). Para isso, os estudantes efetuaram uma autoavaliação do processo projetual e os pares docentes participaram de uma avaliação quantitativa de resultados e de outra qualitativa, analisando os efeitos da atividade realizada na formação projetual.

\subsection{AUTOAVALIAÇÃO DOS ESTUDANTES}

Tendo em vista a essência colaborativa da investigação-ação e a motivação crucial desta pesquisadora, que centrava esforços em auxiliar os estudantes e facilitar o processo 
educativo, tornou-se imprescindível ouvir os alunos. Suas opiniões eram essenciais tanto para identificar possíveis alterações no rumo da pesquisa quanto para detectar se as ações provocaram algum efeito nos processos individuais.

Os depoimentos foram coletados durante a terceira interação, após o uso do Diagrama REC e do Mapa de Categorias Expressivas de modo coordenado, para delimitação dos objetivos. As opiniões foram expressas para todo o grupo, em depoimentos livres, gravados em vídeo. Não havia um limite para o número de vezes que um estudante poderia se manifestar e o encadeamento de ideias entre os participantes era bem-vindo.

Como o intuito era observar os efeitos da utilização do instrumental metodológico, a única orientação foi para que falassem abertamente sobre o que experimentaram, podendo abordar facilidades ou dificuldades sentidas no decorrer do processo até aquele ponto.

A análise dos dados foi realizada pela técnica de análise de conteúdo, empregando novamente os procedimentos de pré-análise, descrição analítica e interpretação inferencial. Considerando os pontos críticos apontados no diagnóstico e as sínteses conceituais estratégicas, foi possível classificar os dados em facilidades ou dificuldades acerca: do entendimento de utilização das ferramentas; da gestão sistêmica de informações e delimitação de objetivos; da síntese e aplicação de diretrizes expressivas para a sintaxe da forma. Sobre estes pontos foram esquadrinhadas as apreciações dos estudantes e, em seguida, foram sintetizadas em temas descritores. Os resultados foram separados por contribuições de cada ferramenta, estratégias consideradas relevantes e dificuldades vivenciadas.

\subsubsection{DIAGRAMA REC}

Os estudantes que se manifestaram sobre esta ferramenta, em sua totalidade, emitiram opiniões que corroboraram o papel facilitador na delimitação projetual ou na organização do pensamento. Nesta direção, as facilidades comentadas foram reunidas em tópicos, nos quais se manteve uma proximidade com a linguagem natural dos participantes: a) facilitou a organização do pensamento; b) auxiliou a gestão do 
processo do início ao fim (manteve o foco); c) ajudou na percepção da evolução do próprio pensamento projetual (no projeto e na disciplina); d) facilitou a identificação das necessidades do público e a "visualização" dos objetivos coerentes; e) proporcionou a visão em conjunto e ajudou a conectar os objetivos (de utilidade, ergonomia e linguagem) / proporcionou a visão de como cada parte se relaciona com o todo (análise e síntese); g) é flexível - o movimento das informações no diagrama permitiu a evolução das ideias e é aplicável em outros projetos.

\begin{abstract}
Acho que o principal foi conseguir relacionar o todo em uma coisa única, porque eu tinha muita dificuldade nisso, de pensar cada parte de forma particular e conseguir relacionar. Ana Aiub (2015)

Eu gostei bastante do projeto e eu achei legal a parte que os objetivos tinham que te acompanhar do início até o final, porque muitas vezes a gente se perde no processo e acaba desligando das coisas certas que você tem que cumprir. Juliana Nakatani (2015)

Eu acho que o pessoal destravou mais dessa vez, nessa parte de pensar, de pensamento do começo. [...] então eu acho que foi bom para entender o processo de cada um. Lisandra Francine (2015)
\end{abstract}

Achei muito legal essa parte dos subsistemas, você enxergar os objetivos e a diferença de cada objetivo, em que ramo eles estão, que ramo eles abordam. Carolise Vilela (2015)

[...] acho que ajudou bastante porque você visualiza bem melhor as delimitações do projeto, para você ter a possibilidade de mudar as coisas de lugar, não definir tudo ali num primeiro momento, eu acho que isso ajudou bastante. Isadora Coelho (2015)

Eu acho que a gente conseguiu trabalhar muito o ergonômico, a parte visual, acho que misturou tudo, juntou tudo. Foi uma evolução dos últimos projetos que a gente fez. Nicole Almeida (2015)

Nossa experiência com a ferramenta foi ótima, sendo prática e prazerosa de usar, traz resultados fidedignos de modo muito rápido, isso é ótimo, já que o designer de moda tem que estar em constante desenvolvimento. Jônatas Delmonaco (2015)

Para reforçar as percepções sobre o emprego do Diagrama REC, esta etapa foi complementada com as declarações do grupo de segunda série que completou a segunda interação em 2014, quando sucedeu a primeira aplicação do Diagrama REC. Os depoimentos foram tomados um ano depois da atividade (no ano letivo de 2015). O propósito deste distanciamento cronológico foi averiguar que contribuições foram assimiladas e retidas como pontos relevantes no uso desta ferramenta. 
Os depoimentos sobre o Diagrama REC neste grupo enfatizaram alguns pontos em comum com o grupo anterior: a) facilitou a organização do pensamento; b) auxiliou a gestão do processo do início ao fim (manteve o foco); c) proporcionou a visão em conjunto e ajudou a conectar as variáveis (utilidade, ergonomia e linguagem)/ proporcionou a visão de como cada parte se relaciona com o todo (análise e síntese).

No entanto, algumas colocações evidenciaram reflexões mais maduras, empreendendo análises sobre o pensamento projetual. Evidentemente, a maior vivência de práticas projetuais e a aquisição de conteúdos teóricos mais complexos, na terceira série, poderiam ter contribuído muito na transferência de conceitos para estas análises.

Estas declarações são muito importantes para o escopo desta pesquisa, pois se referem à percepção dos efeitos facilitadores da gestão projetual. Elas podem ser resumidas em três efeitos descritos: a) auxiliou a ampliar os pontos de vista sobre o problema (visão sistêmica), depois a afunilar e manter o foco; b) pesquisa e geração caminharam juntas; c) o desenho do corpo agregado à ferramenta ajudou a delimitar melhor as necessidades e a perceber a "forma" do produto.

Ao mesmo tempo em que você está pesquisando, você está gerando. Realmente, enquanto você está pesquisando para preencher aquela tabela (de objetivos), para saber o que vai usar, o produto já está sendo criado ali, naquele momento. Você percebe de repente que você já tem o produto. [...] Tudo que ele (produto) precisa, já está ali descrito e vai sendo gerado. Pesquisa e geração andam juntas. Alessandra de Paula (2015)

Aquele bonequinho (representação do corpo), ele permite olhar primeiro para o corpo e pensar onde tem os problemas, onde eu posso solucionar algo, "o que" posso fazer aqui... E depois eu penso em "como" fazer isso. [...] faz a gente chegar em um produto mais coerente, a gente chega em um produto mais seguro, que realmente responda os problemas que a gente pretende solucionar. Yara Silveira (2015)

A gente consegue ver sistemicamente para depois afunilar. Luana Bortoletto (2015)

No terceiro ano a gente estudou bastante sobre visão sistêmica, que em teoria é um conceito muito legal, é algo muito válido que a gente realmente tem que aplicar como designer. Só que na prática isso é muito difícil, você ter uma visão que abrange um sistema todo mas conseguir manter o foco. $\mathrm{E}$ a ferramenta faz isso, ela permite que a gente tenha uma visão do sistema todo, mas que a gente também consiga manter o foco. Yara Silvestre (2015) 


\subsubsection{MAPA DE CATEGORIAS EXPRESSIVAS}

Os estudantes que se manifestaram a respeito do MCE centraram suas opiniões na função facilitadora da ferramenta. Os depoimentos ressaltaram que o MCE ajudou a sanar a dificuldade de extrair elementos expressivos e realmente transformá-los em princípios sintáticos de forma. Sobre isso, foram enfatizadas as seguintes contribuições. a) ajudou a gerar várias possibilidades (ideias de solução); b) serviu como guia para decidir (com maior velocidade); c) comparando com o painel semântico tradicional, foi mais eficiente para auxiliar na extração de elementos sintáticos; d) facilitou a expressão daquilo que se quer transmitir no produto; e) ajudou a "passar" os elementos da imagem para a configuração do produto (geração tridimensional da forma).

\footnotetext{
Eu gostei bastante de várias ferramentas que a gente viu aqui. Visualizar bem quais eram as necessidades mesmo, porque tudo que a gente identificou, incluiu no produto. [...] Como todo mundo falou, acho que realmente o diferencial semântico ${ }^{55}$ é bem mais prático do que o painel semântico, ficou bem mais fácil de visualizar as cores, as formas e tudo que a peça deveria ter. Amanda Pilla (2015)

O quadro semântico ajudou muito na parte da linguagem. Eu sempre tive muita dificuldade em transmitir exatamente o que a gente queria. Tinha todo o conceito na nossa cabeça e na hora de passar aquilo para a roupa travava, não dava certo. Então, o quadro nos ajudou a perceber todos os elementos que a gente tinha que colocar na roupa para transmitir aquilo, principalmente delimitar o verbo. O verbo é o conceito que a gente criou para nossa roupa, aquilo foi muito nítido como melhorou. Espero que apareça no resultado também. Amanda Spinassi (2015)
}

\subsubsection{SOBRE AS ESTRATÉGIAS USADAS NA ATIVIDADE}

Vários depoimentos ressaltaram vivências específicas que foram consideradas importantes para a evolução projetual ou que amenizaram dificuldades anteriores.

A este respeito foi possível observar destaques nos temas subsequentes: a) foi mais fácil usar ferramentas pensadas para a área de moda; b) agregar a experimentação tridimensional da forma e das tecnologias (material e técnicas de confecção) ajudou a

55 O Mapa de Categorias Expressivas, que no momento dos depoimentos ainda não tinha denominação específica, foi citado por uma aluna como "diferencial semântico" e pela outra como "quadro semântico". 
ampliar as possibilidades (sair da ideia predefinida); c) o acompanhamento dos professores manteve o ritmo do trabalho e o interesse; d) a parceria com a marca inseriu limitações que ampliaram a visão de necessidades a serem atendidas; e) gerar a forma no corpo auxiliou na percepção da interação dos volumes do corpo com o volume têxtil e a viabilidade concomitantemente; f) a experimentação com o material despertou ideias sobre a forma e ajudou a geração de alternativas.

E agora, tendo todos esses tipos de malha e vendo que têm tantas opções dentro da palavra malha, facilita um pouco, amplia nosso campo de visão em relação ao material, porque a gente sempre tem uma ideia predefinida. E a gente viu que é muito mais amplo, tem muito mais possibilidades dentro desse material, que é um só. Isabella Beraldo (2015)

Eu achei ótima! Foi a ferramenta que mais me adaptei e que vi mais eficácia, por ser destinada para o produto de moda facilita muito. As outras ferramentas me confundiam pois eram muito amplas, não me direcionava no que eu precisava. Izabel Aguilar (2015)

Particularmente foi a ferramenta que até então mais me adaptei e tive facilidade de utilizar de forma mais intuitiva, sem tanta dependência de um professor para explicar toda hora a maneira mais adequada de usar. Acredito que por ser mais visual tenha facilitado esse trabalho, mas principalmente, por ser uma metodologia específica para área de design de moda, diferentemente daquelas que vínhamos usando que em sua maioria necessitavam de uma adaptação pra ser utilizada nos nossos projetos de sala de aula. Milena Garcia (2015)

[...] trabalhar com a moulage era uma coisa que eu nunca tinha trabalhado, foi uma coisa bem interessante de gerar alternativa, porque eu tenho muita dificuldade com desenho, então eu vendo no manequim foi bem mais fácil. Acho que para as meninas que estavam comigo também, [...] a dificuldade de imaginar como a modelagem acontece. Porque a gente teve dificuldade na modelagem com desenho, mas na modelagem tridimensional a gente começou a sanar isso, a perceber automaticamente que algo não dava certo porque a gente vê a construção da peça direto no corpo. Às vezes imaginando a gente não consegue, ou só desenhando, a gente deixa passar alguma coisa. Lisandra Francine (2015)

\subsubsection{SOBRE DIFICULDADES VIVENCIADAS}

As dificuldades comentadas (e observadas) foram poucas e se referiam, principalmente, ao fator novidade. Houve dúvidas iniciais sobre como utilizar a nova forma de organizar as informações, ou inseguranças provocadas pela autonomia de decisões, já que o registro das informações nas ferramentas oferecia grande liberdade. Entretanto, alguns 
pontos merecem ênfase, pois são valiosos no primeiro contato das ferramentas com um grupo de alunos.

O primeiro ponto não se refere a uma dificuldade de utilização das ferramentas propostas, mas a um preconceito que, aparentemente, leva a uma resistência inicial: ver qualquer método como uma trajetória rígida de passos a seguir, aprisionadora. Observou-se que essa prevenção, que pressupõe passos rígidos a trilhar, paradoxalmente, pode levar o aluno a se sentir um pouco confundido, quando se dá conta dos movimentos de avanços e retrocessos compreendidos nos ciclos do pensamento projetual.

Outra questão importante, expressa por um estudante, foi a dificuldade de documentar o processo. Apesar de ser uma rotina nas atividades projetuais do curso, alguns parecem não ter assimilado o hábito de registros com muito detalhamento. Porém, devido aos ciclos de realimentação do Diagrama REC e do uso das ferramentas para comunicação intergrupal, este aluno constatou que registrar as sínteses era relevante para a evolução das suas ideias. Isso reforçou a indicativa de inserir os registros desde o início do processo.

De qualquer forma, os discentes que citaram dificuldades no uso das ferramentas utilizaram expressões como "no início eu senti", "no começo foi", "mas depois percebi que", sugerindo que consideravam aquelas questões sanadas, ou amenizadas, no momento da coleta do depoimento.

[...] me deixou um pouco confusa no começo, mas depois com os objetivos, na geração de alternativas, deu para perceber como foi importante tudo aquilo para definir o objetivo certinho. Simone Tavares (2015)

No começo, eu estava meio confuso, meio com raiva e depois foi melhorando, foi fluindo [...] eu gostei bastante. Apesar de ser uma metodologia nova, acabou sendo um pouco mais fácil, ainda que a gente tenha batido um pouco a cabeça e ficou meio preso numa ideia. E agora não. Agora está fluindo melhor. Ontem a gente teve acho que um salto muito grande [...] e agora a gente está numa fase bem avançada. Everton Silvestre (2015)

A maior dificuldade que tivemos foi na hora de avaliarmos os resultados colocando em tabelas específicas. Porém com um pouco de paciência e orientação conseguimos utilizar satisfatoriamente. Jônatas Delmonaco (2015)

Em um exame geral, as falas dos participantes evidenciaram conteúdos de autocrítica e demonstrações da assimilação de suas próprias condutas projetuais, 
indicando um possível amadurecimento no que concerne à autonomia e a "reflexão sobre a ação", segundo recomendações dadas por Lawson (2011), Schön (2000) e Franzato (2012).

Resgatando as dificuldades apontadas no diagnóstico, observa-se que os depoimentos apontaram várias contribuições para amenizá-las, conforme mostram as inferências no Quadro 18.

Quadro 18 - Correlações entre dificuldades diagnosticadas e contribuições citadas pelos estudantes

\begin{tabular}{|c|c|}
\hline DIFICULDADE & CONTRIBUIÇÕES RELACIONADAS \\
\hline $\begin{array}{l}\text { Desvencilhar-se de uma ideia } \\
\text { preconcebida }\end{array}$ & $\begin{array}{l}\text { - Ajudou a gerar várias possibilidades (ideias de solução). } \\
\text { - Agregar a experimentação tridimensional da forma e das } \\
\text { tecnologias (material e técnicas de confecção) ajudou a ampliar } \\
\text { as possibilidades (sair da ideia predefinida). }\end{array}$ \\
\hline $\begin{array}{l}\text { Transpor as informações } \mathrm{p} / \mathrm{a} \\
\text { síntese de objetivos }\end{array}$ & $\begin{array}{l}\text { - Facilitou a identificação das necessidades do público e a } \\
\text { "visualização" os objetivos coerentes. } \\
\text { - Proporcionou a visão do conjunto e ajudou a conectar os } \\
\text { objetivos (utilidade, ergonomia e linguagem). } \\
\text { - Facilitou a organização do pensamento. } \\
\text { - Pesquisa e geração caminharam juntas. }\end{array}$ \\
\hline $\begin{array}{l}\text { Integrar os objetivos na } \\
\text { materialização do projeto }\end{array}$ & $\begin{array}{l}\text { - Auxiliou a gestão do processo do início ao fim (manteve o foco). } \\
\text { - Facilitou a expressão daquilo que se quer transmitir no produto; } \\
\text { proporcionou a visão de como cada parte se relaciona com o todo } \\
\text { (análise e síntese). } \\
\text { - Proporcionou a visão em conjunto e ajudou a conectar os } \\
\text { objetivos (utilidade, ergonomia e linguagem). } \\
\text { - O desenho do corpo agregado à ferramenta ajudou a delimitar } \\
\text { melhor as necessidades e a perceber a "forma" do produto. } \\
\text { - Pesquisa e geração caminharam juntas. }\end{array}$ \\
\hline $\begin{array}{l}\text { Transpor as sínteses } \\
\text { imagéticas para a configuração } \\
\text { tridimensional dos produtos }\end{array}$ & $\begin{array}{l}\text { - Ajudou a "passar" os elementos da imagem para a configuração } \\
\text { do produto. *(com maior velocidade) }\end{array}$ \\
\hline $\begin{array}{l}\text { Selecionar e organizar as } \\
\text { informações pesquisadas }\end{array}$ & $\begin{array}{l}\text { - Facilitou a identificação das necessidades do público e a } \\
\text { "visualização" dos objetivos coerentes. } \\
\text { - Facilitou a organização do pensamento. } \\
\text { - Auxiliou a ampliar os pontos de vista sobre o problema (visão } \\
\text { sistêmica), depois a afunilar e manter o foco. }\end{array}$ \\
\hline Selecionar a melhor ideia & $\begin{array}{l}\text { - Serviu como guia para decidir. } \\
\text { - Pesquisa e geração caminharam juntas. }\end{array}$ \\
\hline Seguir metodologia & $\begin{array}{l}\text { - Ajudou na percepção da evolução do próprio raciocínio projetual } \\
\text { (no projeto e na disciplina). } \\
\text { - Facilitou a organização do pensamento. } \\
\text { - Auxiliou a gestão do processo do início ao fim (manteve o foco). }\end{array}$ \\
\hline Seguir cronograma & poimentos que abordassem este tema. \\
\hline
\end{tabular}




\subsection{AVALIAÇÃO DOS PARES}

Para validação das ferramentas foi fundamental a participação dos professores colaboradores, os quais agregaram pontos de vista distintos, de suas áreas específicas, e ajudaram a manter a objetividade das observações desta pesquisadora. Salienta-se, também, que os pares colaboradores acumulavam anos de experiência com os Projetos Integradores, contribuindo igualmente com percepções precedentes sobre o ambiente estudado.

Portanto, os colaboradores retinham conhecimento prático e teórico apropriados para serem classificados como especialistas, em suas áreas de atuação, no ambiente pedagógico estudado. Por isso, suas contribuições foram aportadas à pesquisa com duas finalidades: a) avaliar a coerência dos resultados gerados na interação com as ferramentas; b) observar efeitos inovadores no decorrer da prática projetual em classe.

\subsubsection{AVALIAÇÃO QUANTITATIVA DOS RESULTADOS}

A avaliação dos resultados da terceira interação (Projeto Leveza do Ser) teve o propósito de verificar o alcance dos objetivos, demonstrando se o processo de cada grupo chegou ao final mantendo o foco e agregando os preceitos da delimitação projetual na sintaxe da forma.

Convém esclarecer que este procedimento não atribuía uma quantificação ao rendimento do aluno na disciplina de Metodologia do Projeto. A avaliação serviu apenas como mecanismo quantitativo para a pesquisa e foi aceita com naturalidade pelos alunos, que já estão habituados a defender todos os seus projetos para um grupo de professores.

No último dia da terceira interação em campo, cada grupo apresentou o seu projeto e os docentes o pontuaram. Para a pontuação foi empregada uma tabela padrão, que consistia em uma adaptação do modelo de ficha de avaliação e seleção de alternativas. Em semelhança à tabela usada pelos estudantes, o documento continha os objetivos delimitados pelo grupo e uma indicação cromática, vinculando os objetivos aos subsistemas funcional, ergonômico e formal. 
Figura 43 - Exemplo de Ficha de Avaliação

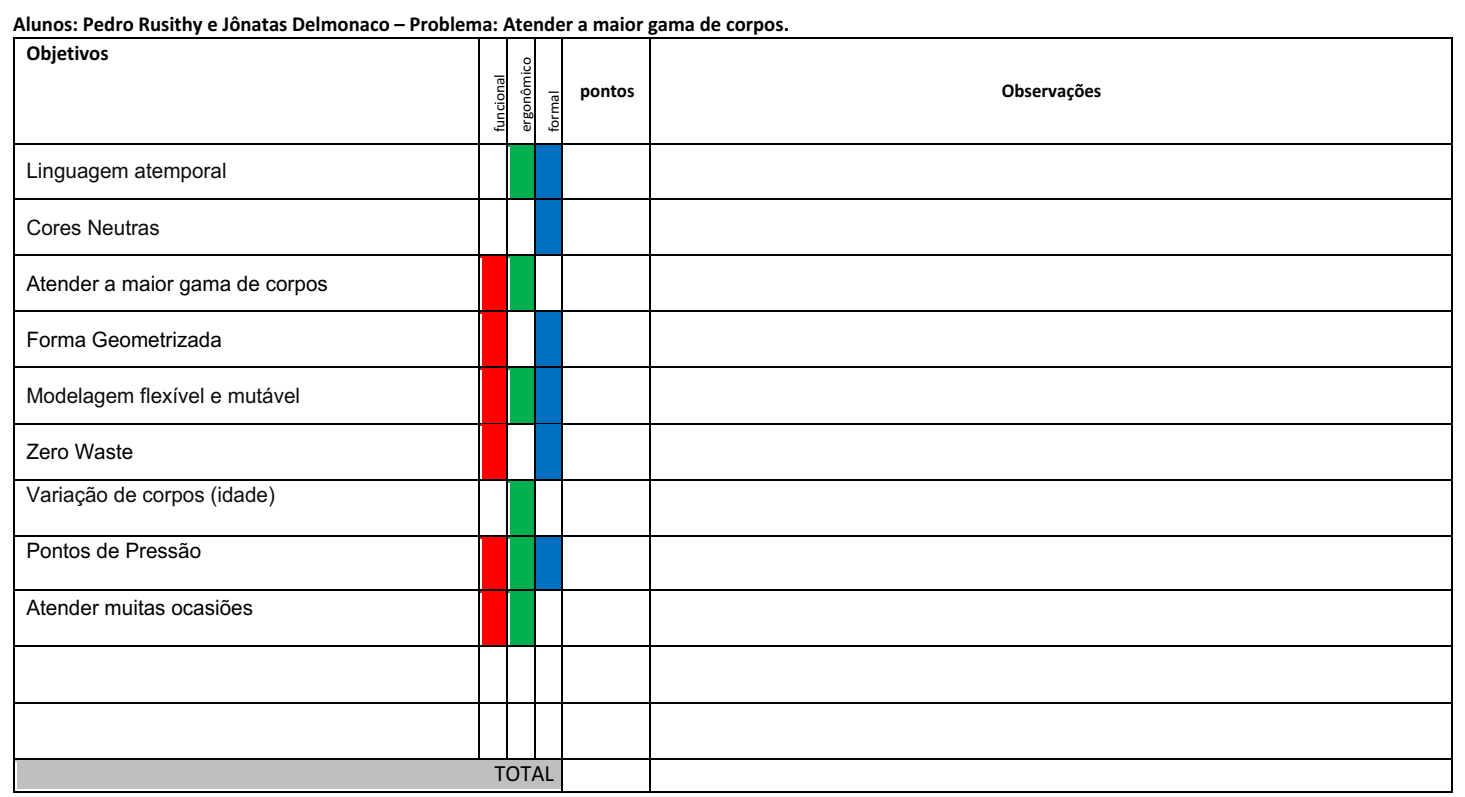

Cada professor recebeu uma cópia da ficha de cada dupla, na qual deveria valorar o grau de alcance dos objetivos, conforme ilustrado na Figura 43. Após a avaliação dos objetivos isoladamente, o docente atribuía um conceito geral para o alcance de objetivos em sua área específica.

Os pares foram orientados a não avaliar itens nos quais não se sentissem seguros. Essa situação poderia ocorrer por motivos como: não estar vinculado à sua área; não conseguir perceber nitidamente; não haver comentários claros na defesa verbal dos alunos, deixando dúvidas.

As fichas foram examinadas de forma qualitativa e quantitativa, visando a uma percepção mais confiável do grau de atendimento dos objetivos por cada grupo. Neste rumo, cada ficha recebeu os seguintes procedimentos: a) contagem do total de pontos positivos; b) cálculo do percentual de valores positivos, aferido em proporção ao número de objetivos avaliados pelo professor; c) análise dos conteúdos das eventuais observações anotadas pelo professor na ficha. 
Foram reunidas as pontuações de todos os avaliadores para um mesmo grupo e foi calculada a média ponderada entre os valores, revelando o percentual geral de alcance de objetivos por grupo (Figura 44).

A finalidade da quantificação não era averiguar uma estatística precisa de cada grupo, mas observar qualquer evidência de percentuais significativos ao compará-los na totalidade dos grupos.

Figura 44 - Índice geral de alcance dos objetivos por grupo

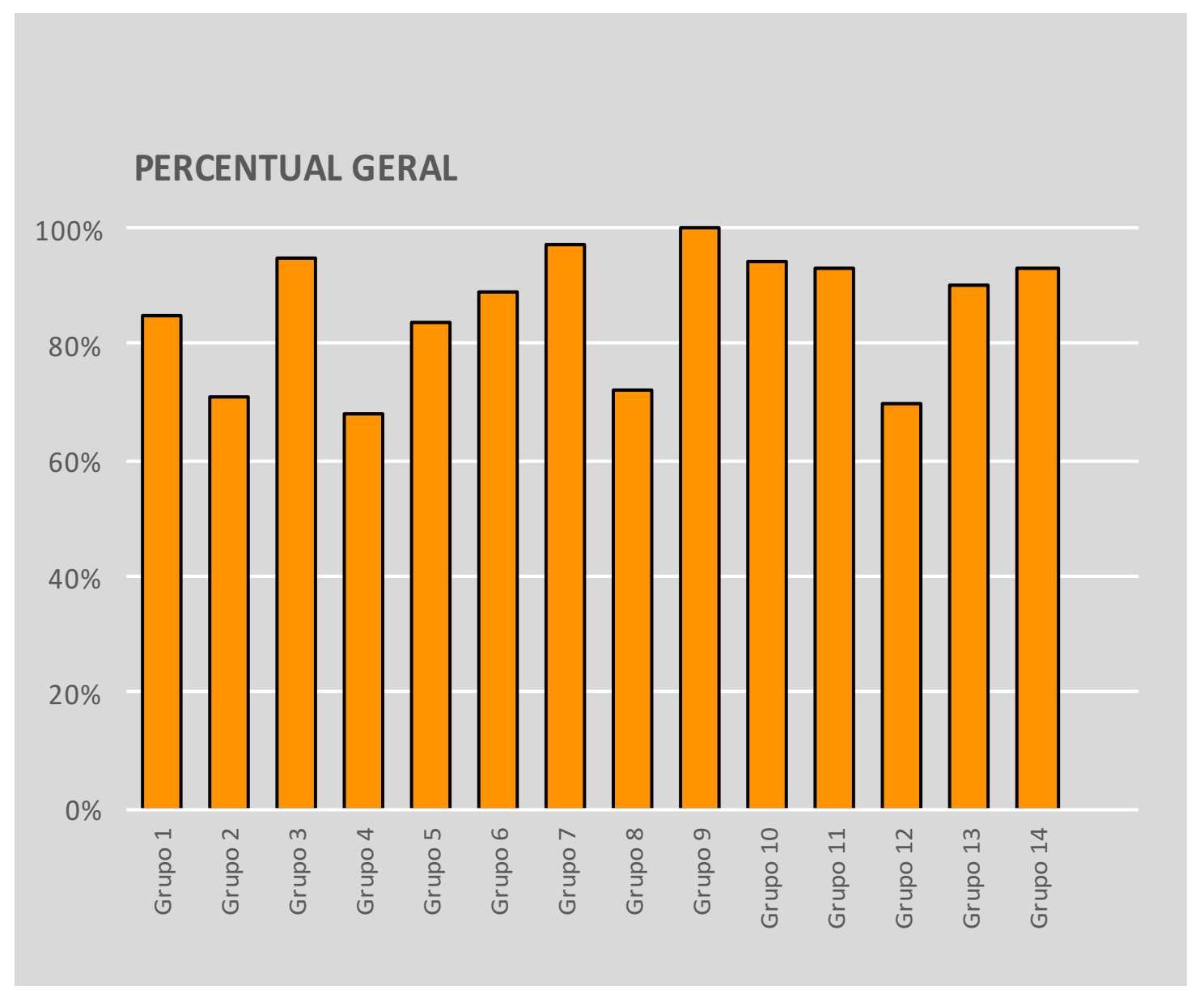

Fonte: elaborado pela autora com base na pesquisa realizada (2016)

Outro ponto analisado e quantificado foi o percentual gerado por cada especialista para cada grupo. A análise resultou em um gráfico de alcance de objetivos por área, apresentado na Figura 45. 
Figura 45 - Índice de alcance dos objetivos por cada professor avaliador

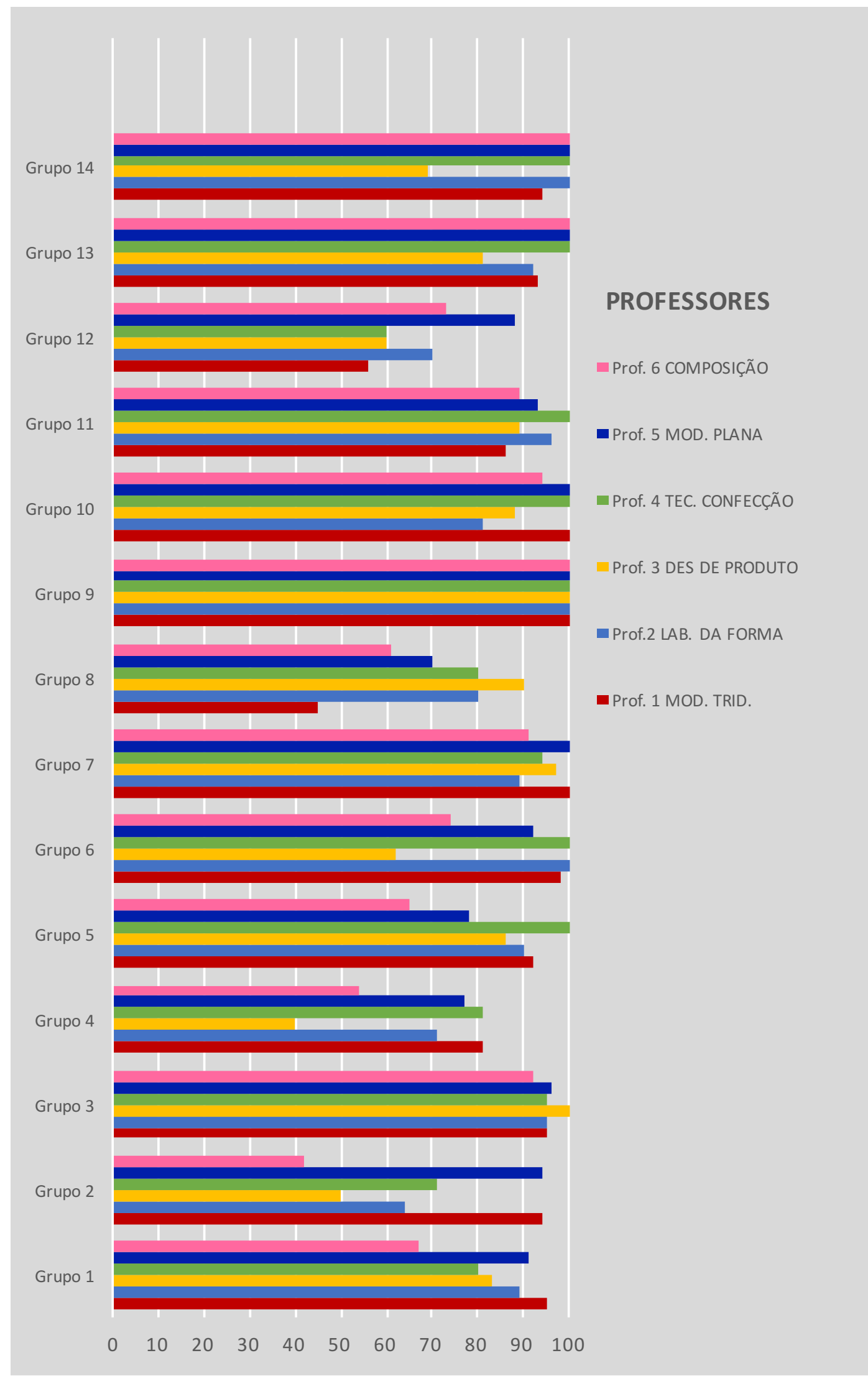

Fonte: elaborado pela autora com base na pesquisa realizada (2016) 
Todavia, a análise qualitativa dos comentários demonstrou que alguns professores podem ter empregado a valoração AP (atendeu parcialmente) influenciados pela qualidade da confecção do protótipo, avaliando-o como produto final ou, ainda, pode ter ocorrido uma dificuldade para avaliar, separadamente, sua especialidade, sem sofrer influências da qualidade de acabamento do protótipo, mesmo sendo advertido de que os próprios alunos o realizaram e era a primeira vez que experimentavam a confecção em malha.

Ainda assim, a quantificação dos dados demostrou um bom índice de avaliação por área e dez grupos atingiram mais de $80 \%$ na avaliação geral. Ao analisar os comentários da professora de laboratório da forma, que acompanhou todo o projeto, para os quatro grupos que ficaram abaixo deste índice, foram detectadas observações relevantes: dois receberam uma boa avaliação qualitativa sobre a proposta formal apresentada e os outros dois, embora tenham perdido características da forma planejada, na finalização do produto, receberam boas considerações sobre o processo de desenvolvimento da forma. Logo, constatou-se que os grupos mantiveram os objetivos integrados no decorrer da trajetória projetual, agregando os preceitos da delimitação inicial na sintaxe da forma.

Para captar a percepção geral dos pares sobre a experiência em campo e obter contribuições sobre questões relativas às condutas no processo projetual dos estudantes, realizou-se um focus group com o mesmo conjunto de professores. Em relação a esta abordagem qualitativa, o texto subsequente expõe os detalhes.

\subsubsection{AVALIAÇÃO QUALITATIVA DE PROCESSO}

A mesma equipe de professores se reuniu três meses depois da avaliação quantitativa dos resultados. O propósito do intervalo foi dar tempo para a segunda aplicação das ferramentas, a qual ocorreu sem a presença da presente pesquisadora e foi inserida no projeto integrador da segunda série, com o mesmo grupo de alunos. Deste modo, foi possível verificar a autonomia do instrumental e os docentes tiveram a oportunidade de observar novamente a utilização para aprofundar suas percepções. 
Martins e Theóphilo (2009) reforçam que a técnica de focus group é bastante produtiva para comparação com as anotações registradas em uma observação participante. No caso desta pesquisa, considerou-se bastante adequada, uma vez que as informações recolhidas procediam de especialistas na área de moda, que poderiam contribuir com visões específicas e correlacioná-las ao conhecimento compartilhado do ambiente estudado.

A sessão de focus group teve duração de duas horas e a moderação foi efetuada pela presente pesquisadora. Os direcionadores da moderação fundamentaram-se nos objetivos da pesquisa e foram especificados a partir dos princípios que guiaram a atuação em campo, a lembrar: gestão da informação que integre melhor as variáveis (delimitação sistêmica); maior aproveitamento das ferramentas de síntese imagética (facilitar a identificação dos elementos sintáticos e semânticos); experimentação tridimensional agregada à sintaxe da configuração; ferramentas que permitam a fluidez do pensamento divergente e, também, estimulem as conexões para a convergência das informações em objetivos.

Sobre estes indicadores, os tópicos, definidos para impulsionar os depoimentos, e auxiliar a organização posterior dos dados, concentraram-se em quatro tipos de percepções:

A) Sobre facilidades ou dificuldades na operacionalização das ferramentas.

B) Acerca da gestão de informação e delimitação projetual.

C) Sobre a síntese e aplicação de diretrizes expressivas (sintáticas/semânticas) na geração da forma.

D) A respeito dos comportamentos de aprendizagem ou gestão do pensamento projetual no decorrer da atividade ou na apresentação dos resultados.

Aplicando uma conduta de codificação, como a empregada no focus group anterior, com o grupo de alunos, analisou-se a transcrição dos depoimentos e foram sintetizados os resultados expostos no Quadro 19. 
Quadro 19 - Síntese dos resultados do focus group com os pares

\begin{tabular}{|c|c|c|}
\hline Diretriz de Moderação & Desdobramentos & Pontos Destacados \\
\hline $\begin{array}{l}\text { Facilidades ou } \\
\text { dificuldades na } \\
\text { operacionalização das } \\
\text { ferramentas: }\end{array}$ & $\begin{array}{l}\text { Interação fácil, inclusive de } \\
\text { modo autônomo. } \\
\text { Interação forma e corpo: a } \\
\text { representação do corpo na } \\
\text { ferramenta potencializou as } \\
\text { conexões entre os } \\
\text { subsistemas e o } \\
\text { entendimento dos } \\
\text { delimitadores da forma. } \\
\text { Aprendizado em grupo: as } \\
\text { discussões em grupo } \\
\text { facilitaram o entendimento } \\
\text { das ferramentas no primeiro } \\
\text { uso. } \\
\text { Comunicação e gestão do } \\
\text { trabalho em equipe: DREC e } \\
\text { MCE potencializaram } \\
\text { discussões e os mantiveram } \\
\text { conectados; auxiliam a } \\
\text { distribuição de tarefas ou } \\
\text { organização do tempo. }\end{array}$ & $\begin{array}{l}\text { Apesar do reconhecimento da } \\
\text { facilidade de interação com os alunos, } \\
\text { os professores sugeriram que houvesse } \\
\text { um guia de aplicação das ferramentas } \\
\text { para professores. } \\
\text { A supressão espontânea de } \\
\text { experimentação tridimensional } \\
\text { intermediária para alunos com bom } \\
\text { repertório de modelagem plana (na } \\
\text { segunda aplicação) foi vista como } \\
\text { evidência de eficácia na conexão entre } \\
\text { objetivos e construção do produto. } \\
\text { Porém, concluiu-se que a } \\
\text { experimentação formal deve ser } \\
\text { estimulada como meio de exploração } \\
\text { divergente na geração de ideias. } \\
\text { A transposição do gesto para a } \\
\text { representação do corpo foi muito } \\
\text { importante para impulsionar a geração } \\
\text { tridimensional. } \\
\text { As ferramentas auxiliam a comunicação } \\
\text { grupal e os alunos parecem se organizar } \\
\text { melhor para distribuir tarefas e manter } \\
\text { o foco integrado, mesmo trabalhando } \\
\text { em separado }\end{array}$ \\
\hline $\begin{array}{l}\text { Gestão de informação e } \\
\text { delimitação projetual: }\end{array}$ & $\begin{array}{l}\text { Convergência: coerência e } \\
\text { foco; maior qualidade de } \\
\text { síntese. } \\
\text { Divergência: exploração } \\
\text { mais ampla e diversificada das } \\
\text { análises do problema. } \\
\text { Gestão sistêmica da } \\
\text { informação: visualização das } \\
\text { conexões entre as } \\
\text { informações e identificação } \\
\text { de lacunas na investigação. }\end{array}$ & $\begin{array}{l}\text { Qualidade de síntese e coerência: } \\
\text { conexões mais maduras e análises mais } \\
\text { complexas, maturidade inédita em } \\
\text { comparação às experiências anteriores. } \\
\text { O DREC ajudou a vincular as } \\
\text { informações e a enxergar as lacunas na } \\
\text { pesquisa e delimitação. } \\
\text { A gestão da informação ajudou a } \\
\text { perceber lacunas de conhecimento, } \\
\text { guiando a busca por informações para } \\
\text { supri-las. }\end{array}$ \\
\hline $\begin{array}{l}\text { Síntese e aplicação de } \\
\text { diretrizes expressivas na } \\
\text { geração da forma: }\end{array}$ & $\begin{array}{l}\text { Otimização da síntese } \\
\text { imagética: mais facilidade e } \\
\text { agilidade para interpretação } \\
\text { de referências e extração de } \\
\text { elementos de forma. } \\
\text { Sintaxe visual ampliada: } \\
\text { desdobramento de linguagem } \\
\text { em coleção; diversificação de } \\
\text { propostas formais. } \\
\text { Coerência entre a síntese da } \\
\text { forma e o pensamento } \\
\text { expressivo / linguagem. }\end{array}$ & $\begin{array}{l}\text { A vinculação entre os elementos do } \\
\text { MCE, a experimentação em moulage e } \\
\text { transposição à modelagem plana } \\
\text { ocorreu de modo mais natural. } \\
\text { Com o MCE notou-se que os alunos, } \\
\text { além da linguagem, vinculavam as } \\
\text { sínteses visuais e sensórias com } \\
\text { aspectos ergonômicos e operacionais. } \\
\text { Na segunda aplicação percebe-se que o } \\
\text { MCE ajudou no pensamento de coleção } \\
\text { (desdobramento de linguagem). }\end{array}$ \\
\hline
\end{tabular}




\begin{tabular}{|c|c|c|}
\hline & $\begin{array}{l}\text { Experimentação: } \\
\text { modelagem como meio para } \\
\text { estudar e entender os } \\
\text { objetivos do produto. } \\
\text { Conectou a percepção entre } \\
\text { síntese imagética, forma } \\
\text { tridimensional e modelagem } \\
\text { plana. }\end{array}$ & $\begin{array}{l}\text { A modelagem se tornou informação de } \\
\text { delimitação projetual e a moulage } \\
\text { ferramenta de investigação criativa, } \\
\text { facilitando a geração e o entendimento } \\
\text { de construção da forma. } \\
\text { Os elementos sensórios do MCE, } \\
\text { principalmente o gesto, facilitam a } \\
\text { transposição da delimitação conceitual } \\
\text { para a forma tridimensional. }\end{array}$ \\
\hline $\begin{array}{l}\text { Comportamentos de } \\
\text { aprendizagem ou gestão } \\
\text { projetual: }\end{array}$ & $\begin{array}{l}\text { Motivação: tranquilidade no } \\
\text { transcurso da atividade; } \\
\text { afetividade e satisfação com } \\
\text { os resultados. } \\
\text { Interdisciplinaridade: } \\
\text { busca autônoma pela } \\
\text { integração entre professores } \\
\text { e conhecimentos. } \\
\text { Autonomia: liberdade e } \\
\text { segurança para a tomada de } \\
\text { decisões. } \\
\text { Propriedade: autoavaliação } \\
\text { da trajetória projetual e } \\
\text { apropriação das estratégias } \\
\text { para organizá-la. } \\
\text { Prática reflexiva: autocrítica } \\
\text { e autorregulação - percepção } \\
\text { do próprio processo projetual. } \\
\text { Transferência de repertório } \\
\text { de um projeto para outro. }\end{array}$ & $\begin{array}{l}\text { "Fazer" mais consciente e autônomo: } \\
\text { procuram os professores para discutir } \\
\text { questões já formuladas. } \\
\text { Os alunos decidem quando e como } \\
\text { realimentar as informações e buscar } \\
\text { ajuda. } \\
\text { O ambiente físico mais dinâmico, } \\
\text { propicia flexibilidade aos distintos } \\
\text { ritmos de condução entre os grupos. } \\
\text { O processo de construção do produto } \\
\text { ficou mais leve e natural. Modelagem } \\
\text { veio para um momento anterior no } \\
\text { processo projetual, entrou na pesquisa } \\
\text { como informação para delimitação. } \\
\text { Na exposição dos resultados, percebe- } \\
\text { se visão de conjunto, resgatando os } \\
\text { objetivos para justificar as decisões } \\
\text { tomadas. } \\
\text { Era evidente o entusiasmo e orgulho } \\
\text { do próprio projeto. } \\
\text { A parceria com a marca valorizou o } \\
\text { trabalho acadêmico, tornou real o } \\
\text { projeto. }\end{array}$ \\
\hline
\end{tabular}

Fonte: elaborado pela autora com base na pesquisa realizada (2015)

Os depoimentos dos professores forneceram percepções fundamentais para a triangulação com os dados da observação participante e da autoavaliação dos estudantes, propiciando uma legitimação das contribuições para a educação projetual no ambiente investigado. Para uma aproximação do leitor com as opiniões partilhadas entre os docentes, são transcritos alguns trechos das observações.

Como importante contribuição observada, foi unânime a opinião sobre a evolução da maturidade e da autonomia dos alunos participantes, tanto pelos professores que acompanharam todo o processo, quanto pelos que extraíram suas percepções da exposição verbal dos resultados. 
O grau de complexidade e profundidade alcançados no desenvolvimento dos projetos foi muito maior do que os outros projetos que já presenciei nas minhas experiências passadas com o segundo ano. [...] e os alunos conseguirem usar sozinhos (as ferramentas na segunda aplicação) é uma validação importante dessas ferramentas.

Lucimar Emídio

Área: modelagem plana e computadorizada

O processo de autorregulação foi muito melhor. Os processos metacognitivos, eu observei que deu um salto muito grande em qualidade, os vi entendendo o próprio processo de desenvolvimento projetual.

Maria Antônia Romão

Área: composição visual

Eles (alunos) mostravam propriedade ao expor o projeto, então se percebia que era algo que eles realmente tinham construído, não simplesmente "seguindo uma receita", mas compreendendo o que deveria ser feito e, assim, criando a sua "própria receita" para aquela situação projetual. Havia sempre algo de inédito na forma como o aluno colocava o desenvolvimento do projeto.

Valdirene Nunes

Áreas: modelagem plana e tridimensional

Sobre a geração e materialização da forma, os professores que acompanharam o processo ressaltaram a evolução do pensamento de construção e a naturalidade com que ocorreu a experimentação tridimensional. Igualmente, acerca da manipulação de linguagem visual, houve unanimidade sobre o amadurecimento do raciocínio expressivo.

Os alunos que já gostam de experimentar têm mais facilidade. Para as pessoas que não gostam, ou têm alguma insegurança, no momento em que existe uma ferramenta específica, se torna uma coisa palpável, porque realmente acontece. A ferramenta funcionou para ajudar essas pessoas a experimentar a forma. [...] o uso do corpo na ferramenta ajudou muito, ainda mais com aquelas setas indicando os contornos de movimento, eu acho que foi muito importante para eles (alunos) conseguirem fazer aquilo se transformar em produto com maior facilidade.

Patrícia de Mello Souza

Áreas: modelagem tridimensional (técnica e experimentação criativa)

[...] fazer a transposição do gesto para o contorno (representação gráfica sobre corpo na ferramenta), ali é onde a modelagem se resolve de forma mais tranquila, de uma forma automática. [...] na segunda aplicação, alguns grupos foram naturalmente para essa experimentação tridimensional antes da construção do produto, mas alguns grupos não precisaram do tridimensional (experimentação intermediária). Para os que já possuíam um raciocínio de modelagem desenvolvido, já tiveram a visualização do produto, do funcionamento no papel. E passar do papel para a modelagem plana e produto, sem a experimentação também aconteceu de forma natural.

Thassiana Miotto

Áreas: metodologia do projeto e modelagem 
Quando comecei a falar de tecido, e do gesto relacionado ao tecido, vi que eles (alunos) realmente estavam compreendendo o que eu estava dizendo.

\section{Patrícia de Mello Souza}

Áreas: modelagem tridimensional (técnica e experimentação criativa)

Com essa ferramenta (Mapa de Categorias Expressivas), a manutenção de linguagem foi além da simples repetição dos elementos na superfície. Eles conseguem a unidade visual de modos mais complexos. A qualidade de síntese é evidente, a facilidade e agilidade para interpretar a forma a partir das referências. [...] eu percebi também que conectou até mesmo ao que é aplicado na ergonomia, ou até operacionalidade. Agora eles observam com mais facilidade que não é apenas linguagem estética envolvida na forma.

\section{Maria Antônia Romão}

Área: composição visual

Antes eles (alunos) me pediam diagrama (de modelagem) para tudo, agora noto que já estão começando a criar suas próprias modelagens. Eles evoluíram na compreensão tanto da modelagem, quanto na construção do produto. [...] agora eles chegam ao assessoramento com o pensamento pronto, buscam assessoramento para confirmar aquilo que pensaram como solução.

Marlene Carlos

Áreas: modelagem plana e tecnologia da confecção.

Os docentes destacaram a conexão de objetivos e dinamismo dos raciocínios projetuais entre os estudantes, atribuindo a estes fatores uma participação mais ativa dos discentes na integração das disciplinas.

O mais importante de tudo foi a unificação do discurso, porque integra realmente todo mundo. Todos tiveram que trabalhar juntos, os professores na mesma sala de aula em integrações simultâneas. De novo (segunda experiência com as ferramentas), eles (alunos) foram buscar espontaneamente cada professor no momento que foi necessário. Pensando como quem conduz disciplina de projeto, o mais importante foi essa conexão entre as disciplinas, que realmente aconteceu. E aconteceu duas vezes de uma forma que foi natural [...]. Eles precisaram desse assessoramento coletivo, não só da disciplina de um "para isso", ou da disciplina de outro "para aquilo". [...] tudo estava tão conectado que a toda hora havia retornos e avanços, a retroalimentação aconteceu de verdade. Eles voltavam "onde começou" para entender se "o que termino" era eficiente ou não.

Thassiana Miotto

Áreas: metodologia do projeto e modelagem.

Um ponto bastante mencionado na discussão foi o envolvimento afetivo, a motivação percebida no decorrer das atividades, tanto no projeto Leveza do Ser, quanto no projeto integrador subsequente.

[...]porque se, ao utilizá-la (a ferramenta), eles se sentiram motivados, se sentiram seguros, então isso gera o ambiente propício. Essa questão da sala de aula (organização espacial dinâmica), enfim, esse conjunto de ações 
diferentes que aconteceram nesta atividade, e que estão acontecendo agora de novo no PI, contribuíram para que o estado emocional dos alunos fosse propício para a aprendizagem. E isso gera motivação, isso gera aprendizagem significativa. [...] Eu os vejo muito felizes com os resultados, isso ficou muito evidente com os resultados do projeto da Leveza (marca parceira). [...] estão satisfeitos com o próprio trabalho.

Paula Hatadani

Áreas: representação gráfica e desenvolvimento de produto. Coordenadora do curso na época da pesquisa.

Em relação às ferramentas complementares, que foram agregadas no decorrer do processo, os participantes assinalaram a eficácia da ficha de avaliação utilizada na apresentação do projeto Leveza do Ser. Segundo os depoimentos, o documento facilitou a atribuição de valor com mais segurança.

Com este modelo de ficha de avaliação, o objetivo delimitado pelo aluno se torna quantificador do trabalho. [...] também facilitou o feedback.

Thassiana Miotto

Áreas: metodologia do projeto e modelagem.

Acerca das fragilidades que poderiam comprometer a utilização das ferramentas, enfatiza-se que, apesar do reconhecimento da facilidade de interação com os alunos, os professores sugeriram que houvesse um guia de aplicação das ferramentas para docentes, possibilitando a aplicação em outros ambientes acadêmicos.

A supressão espontânea de experimentação tridimensional intermediária, entre alunos com bom repertório de modelagem plana, foi vista como evidência de eficácia na conexão entre objetivos e construção do produto. Porém, concluiu-se que a experimentação formal deve ser incentivada como meio de facilitar a fluidez do pensamento divergente.

Por último, na interação com outro grupo de alunos, quando não houve nenhuma participação desta pesquisadora, as professoras responsáveis experimentaram o primeiro contato com o instrumental de forma individual e coletiva. As observações das docentes mostraram que as discussões em grupo facilitaram o desencadeamento de questionamentos e ampliaram a compreensão de como aproveitar as ferramentas. Deste modo, foi sugerido que o aprendizado de utilização da ferramenta seja realizado em grupo (duplas ou trios), como meio de agilizar o aprendizado da operacionalidade do instrumental. 


\subsection{TRIANGULAÇÃO DOS DADOS E VALIDAÇÃO DO INSTRUMENTAL PROPOSTO}

A triangulação de dados se refere à comparação entre dados recolhidos de fontes distintas (FLICK, 2004; MARTINS; THEÓPHILO, 2009). O recurso se presta à validação de resultados, amplia o espaço de análises e a profundidade das interpretações nas pesquisas qualitativas. Sob este ponto de vista, a triangulação foi valiosa como estratégia nesta pesquisa, tendo em vista o traçado metodológico interdisciplinar e os raciocínios inferenciais implicados na investigação-ação.

Para tanto, procedeu-se uma análise comparativa dos efeitos atribuídos à intervenção em campo. Por meio da triangulação dos dados extraídos das sínteses do diagnóstico, da autoavaliação dos estudantes e da avaliação qualitativa dos pares, foram identificadas decorrências fundamentais para a validação do instrumental proposto. Assim, este tópico emprega inferências da triangulação para amparar a discussão geral dos resultados alcançados, integrando-os nesta análise final. Contudo, a comparação pode ser vista detalhadamente no apêndice $C$.

O conjunto de dados foi organizado e classificado, de acordo com os temas estudados e objetivos desta pesquisa. A classificação se deu pela identificação de padrões entre os efeitos elencados pelos estudantes e professores, unindo-os segundo o seu potencial transformador para atenuar as dificuldades detectadas no diagnóstico.

Para auxiliar a interpretação dos dados, os padrões encontrados foram identificados por temas descritores, sintetizados a partir da correlação do conjunto de dados com os principais conceitos teóricos. Ao final, foram extraídas as transformações atribuídas à vivência experimentada em campo.

A comparação entre os efeitos apontados pelos discentes e docentes evidenciou conceitos subjacentes, que revelaram uma plataforma de elementos propícios à redução das dificuldades diagnosticadas. A triangulação indicou efeitos especialmente relevantes, vinculados aos seguintes pontos:

- fluidez do pensamento divergente/irradiante;

- focalização do pensamento convergente;

- gestão sistêmica da informação;

- experimentação integrada à pesquisa; 
- pontes cognitivas eficazes para a síntese de conceitos formais;

- conduta metaprojetual;

- reflexão "na" e "sobre" a ação;

- comunicação interpessoal;

- conexão afetiva com a aprendizagem;

- autonomia e consciência dos ciclos de análise-síntese-avaliação na condução do projeto.

Os elementos constatados são fundamentais para o escopo desta pesquisa. Os resultados apontaram não apenas um auxílio no desenvolvimento das habilidades de formular, representar e movimentar-se para gerar propostas formais, mas também mostraram que tais habilidades foram conduzidas sob uma postura investigativa e reflexiva, amparando a capacidade de avaliar as possibilidades geradas.

O cruzamento das análises avaliativas demostrou relevante aceitação do Mapa de Categorias Expressivas e do Diagrama REC entre os estudantes e docentes no ambiente acadêmico estudado. No entanto, destacam-se também as contribuições que os participantes forneceram a respeito dos efeitos que requerem cuidados ou podem auxiliar o melhor uso do instrumental proposto: a) efetuar o primeiro uso das ferramentas em grupo; b) elaborar um tutorial destinado a professores, para estender o uso a outros ambientes acadêmicos; c) fomentar o hábito de registro dos processos individuais; d) elucidar os preconceitos relativos às metodologias como algo aprisionador.

Pelo exposto, pode-se concluir que a eficácia do instrumental, como estratégia de "ensinagem", foi comprovada pelos sujeitos envolvidos no estudo. Igualmente, os efeitos observados e os apontados pelos participantes são evidências palpáveis dos preceitos levantados nas bases teóricas, legitimando as ferramentas como facilitadoras da delimitação projetual, da síntese de princípios sintáticos e da experimentação formal.

Deste modo, apresenta-se a versão gráfica final do instrumental (Figura 46), incluindo as ferramentas complementares surgidas em campo. É importante ressalvar que a recomendação de uso do instrumental, indicado pelas setas, foi inserida com base nas condutas observadas em campo, no entanto destaca-se que, embora o Diagrama REC seja o primeiro recurso para impulsionar o processo, a inserção dos outros recursos 
dependerá dos processos individuais. Igualmente, as retroalimentações e a inclusão de novas informações são constantes e, muitas vezes, simultâneas, já que, pela natureza sistêmica, o processo mantém a permeabilidade para acoplar ferramentas e evoluir os conhecimentos construídos.

Figura 46 - Formato definitivo das ferramentas propostas em interação

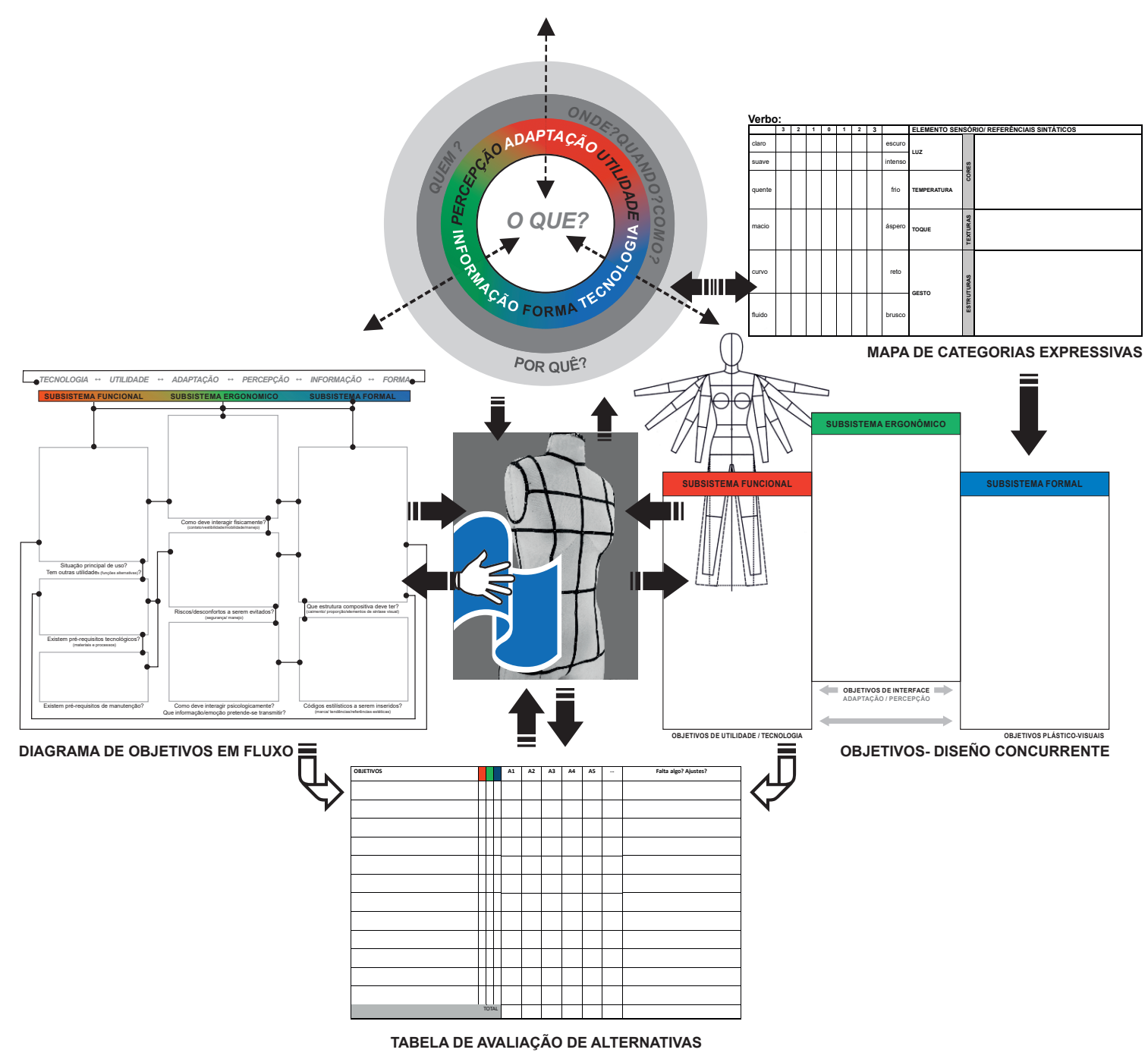

Fonte: elaborado pela autora com base na pesquisa realizada (2016)

Convém esclarecer, acerca das ferramentas complementares, que a organização dos objetivos nos subsistemas do Diseño Concurrente foi realçada, pelos estudantes, como uma importante ajuda na percepção dos equacionamentos que se integram na forma. Do mesmo modo, as observações dos professores colaboradores indicaram que esta plataforma, apoiada pelas palavras-chave do Diagrama REC, colaborou para 
vincular questões operacionais, tecnológicas e ergonômicas na delimitação de parâmetros para a sintaxe da forma. Por isso, as ferramentas complementares mantiveram este vínculo tríplice e o código de cores, sustentando o enfoque conjunto e facilitando a comunicação entre os participantes de um projeto (alunos e professores).

Alguns alunos mostraram dificuldades na primeira tentativa de organizar os objetivos, haja vista que a dimensão funcional do vestuário de moda é, intrinsecamente, ligada à interação corporal e ao conteúdo comunicativo. Por este motivo, foi proposto o Diagrama de Objetivos em Fluxo, correlacionando um fluxo de questionamentos que facilitou a síntese de objetivos. Os questionamentos do diagrama surgiram a partir das indagações mais frequentes dos estudantes, detectadas nos assessoramentos individuais em campo. O diagrama mantém uma unidade gráfica com o círculo interno do Diagrama REC, como se este estivesse aberto, para facilitar a vinculação das informações.

Esta ferramenta foi utilizada pelos alunos e prontamente aceita. Sobre seu emprego como documento de síntese de objetivos, constatou-se que alguns grupos usaram o diagrama em fluxo como substituto da primeira ficha de objetivos (adaptada do modelo original de diseño concurrente), outros o usaram como intermediário para chegar à ficha de objetivos e, por último, notou-se que alguns não o utilizaram e preferiram ir diretamente à referida ficha. Portanto, optou-se em manter as duas estratégias no instrumental, uma vez que a decisão de utilizar uma ou outra poderia se relacionar ao estilo cognitivo dos estudantes para registrar o pensamento, serial ou holístico, como explicado por Cross (2000) nas bases teóricas.

Independentemente do tipo de documento utilizado para registrar os objetivos, estes podem ser transferidos para a Tabela de Avaliação de Objetivos e aplicados como critérios para a análise quantitativa e qualitativa das alternativas de solução.

Finalmente, a ênfase central no desenho do corpo e, principalmente, na experimentação tridimensional, marca a relevância destes elementos como veículos para a pesquisa projetual e para a evolução da sintaxe da forma, como foi atestado pelos participantes do estudo. 


\subsection{CONSIDERAÇÕES FINAIS}

Uma parte considerável dos estudos atuais em design o difunde como uma atividade de natureza sistêmica, em que se detecta claramente o objetivo de mediar relações. Consequentemente, a formação de designers solicita posturas didáticas que sejam guiadas pelo mesmo mote, favorecendo o raciocínio flexível, multifacetado e integrador. Esse posicionamento, compatível com o contexto complexo da contemporaneidade, foi o elemento norteador na construção dos alicerces desta investigação.

Sobre a plataforma da abordagem sistêmica e da aprendizagem significativa, a pesquisa empreendeu esforços em proporcionar estratégias facilitadoras para a prática projetual no âmbito educacional do design de moda. Neste domínio, delimitou-se a trajetória investigativa rumo às estratégias para a sintaxe da composição formal/visual no projeto de vestuário de moda.

Para estudar ferramentas que facilitassem a sintaxe da forma do vestuário de moda, foi essencial reconhecer este artefato como um enunciado não verbal que se integra às mensagens do meio em que se insere, promovendo um processo de identificação e transferência de significados. A experiência humana com a vestimenta desencadeia um processo de experiências tangíveis e intangíveis, enfatizando a veste como interface entre o indivíduo e o entorno, em que a forma sentida é, também, forma percebida e comunicante, como explicado por Castilho (2004), Oliveira $(2007 ; 2011)$, Mello (2011) e Barnard (2003).

Assim, o vestuário de moda participa de relações de adaptação física, expressão individual e representação social, evidenciando a relevância da investigação acerca das conexões entre forma e conteúdo expressivo no projeto deste tipo de produto. Consequentemente, a formação de designers de moda requer que se desenvolva a capacidade para sintetizar e transpor conceitos expressivos para a configuração dos artefatos projetados.

Com o intuito de proporcionar meios para auxiliar o desenvolvimento destas habilidades na educação projetual dos estudantes de Design de Moda na Universidade Estadual de Londrina (UEL), a presente pesquisa centrou-se no estudo da articulação das 
dimensões sintática e semântica na configuração do vestuário de moda, visando a facilitar a geração de possibilidades formais nas práticas projetuais em classe.

Para alcançar esta meta, o alicerce teórico foi construído na transversalidade entre as áreas de design, comunicação visual e pedagogia. Esses campos forneceram as indicativas de abordagem para cumprir o primeiro objetivo específico, que consistia em investigar as estratégias metodológicas para o ensino/aprendizagem de projeto em Design de Moda. Nesta direção, a revisão de literatura indicou a abordagem sistêmica, a aprendizagem significativa e o pensamento visual como arcabouços fundamentais.

Ao agregar estas bases teóricas às constatações do projeto Incubadora de Novas Ideias (projeto de pesquisa na UEL), foram identificadas ferramentas de síntese visual que poderiam auxiliar a decodificação/codificação de referenciais expressivos na composição estético-formal do vestuário de moda, cumprindo assim o segundo objetivo específico deste estudo.

O terceiro objetivo específico previa a proposição de um instrumental metodológico. A proposta deveria facilitar a síntese de códigos expressivos e impulsionar a geração da sintaxe da forma nas práticas projetuais de estudantes de Design de Moda. A este propósito se atrelou a aplicação e avaliação dos efeitos do referido instrumental no percurso projetual dos alunos de Design de Moda da UEL, constituindo o quarto objetivo específico a ser cumprido para completar este estudo.

Embora a proposição inicial das ferramentas tenha derivado da integração das aferições conceituais e da exploração diagnóstica, o terceiro e quarto objetivos foram alcançados de modo interativo, sob uma trajetória de investigação-ação. No transcurso das três interações realizadas, os raciocínios cíclicos da investigação-ação promoveram o ajuste das sínteses iniciais. Deste modo, a proposta conceitual do instrumental norteou a entrada em campo que, por sua vez, contribuiu com desdobramentos espontâneos em sala de aula, respaldando análises e avaliações que agregaram novas especificações para a proposição final.

Finalmente, o instrumental foi avaliado pelos discentes e professores colaboradores que participaram das aplicações em campo. Entre os efeitos apontados pelos sujeitos participantes se destacam: as ferramentas propostas permitiram a interação entre visão panorâmica e capacidade de síntese (divergência e convergência); houve melhor conexão das informações; o Mapa de Categorias Expressivas facilitou e 
agilizou as sínteses expressivas; a experimentação formal serviu como fonte natural de investigação entre problema e solução. Esses resultados apontam características importantes relativas à gestão sistêmica das variáveis projetuais e às habilidades de formular, representar e movimentar-se (LAWSON, 2011).

De outra parte, as evidências observadas, em classe, também apontaram um enriquecimento na capacidade de compreender os equacionamentos simultâneos que constituem a forma do vestuário de moda. Isto é uma evolução importante para a integração dos objetivos projetuais na materialização da configuração, visto que, segundo Lessa (2009), a distribuição e a integração dos componentes formais/visuais são influenciadas pelo partido comunicacional escolhido, mas também por fatores objetivos de operacionalidade, de tecnologia, etc. Niemeyer (2003) atesta, do mesmo modo, a importância desta percepção integrada, advertindo que as qualidades expressivas e representacionais de um produto sugerem, através das suas dimensões sintática e material, as qualidades objetivas e subjetivas de uso.

Pelo exposto, pode-se inferir claramente um progresso na capacidade de delimitar e gerar a organização sintática do vestuário de moda, confirmando a hipótese de que a gestão sistêmica da informação, assistida pelo pensamento visual, facilita a síntese de conceitos expressivos e a percepção das estruturas compositivas para a experimentação da sintaxe da forma.

Em relação ao processo pedagógico vivenciado, as percepções extraídas dos procedimentos avaliativos mostraram que os constructos demarcados para a atuação em campo foram experimentados tanto em nível projetual como em nível didático. Assim, a reconfiguração do sistema projetual, de acordo com a inserção de novas informações e estratégias, promoveu a permeabilidade plástica do projeto. De igual modo, a consciência de um pensamento que integra e a de um aprendizado conectado com a experiência vivida foram indicativos de que os participantes provaram a investigação reflexiva e a reflexão integrativa.

Por este ângulo, acredita-se que a abordagem sistêmica, direcionada pela aprendizagem significativa, permitiu que os alunos experimentassem maior autonomia e reflexão ao gerir o próprio conhecimento, auxiliando a definição do conceito gerador e dos elementos compositivos para a sintaxe da forma projetada. Sob a ótica da aprendizagem significativa, ao estimular a postura proativa e investigativa, pode ser 
criada, entre os sujeitos envolvidos nas práticas educacionais de projeto, uma relação de alteridade.

Ainda sobre os posicionamentos didático-pedagógicos, convém lembrar que a organização do espaço físico, em células de interação com distintas classes de informações, favoreceu a disposição para o trabalho e a colaboração em sala de aula. Isso ratifica a afirmação de que "uma sala de aula interdisciplinar difere da comum desde a organização do espaço arquitetônico até a organização do tempo" (FAZENDA, 2008b, p. 86).

Com base nas constatações anteriores, aferidas a partir de um cauteloso exame dos resultados produzidos pela triangulação dos dados avaliativos e das evidências observadas em campo, conclui-se que o instrumental proposto comprovou sua consistência conceitual e eficácia prática. Não obstante, é importante demarcar algumas limitações, visto que a natureza qualitativa do estudo e a estratégia de investigaçãoação proporcionam um grande aprofundamento específico, mas implicam cuidados com generalizações.

Nesta direção, enfatiza-se que a íntima familiaridade com o universo estudado permitiu uma visão panorâmica do percurso formativo do curso em questão e uma apreciação prévia do raciocínio projetual em formação contínua. Este conhecimento, construído durante os anos de docência nas áreas de metodologia projetual e composição visual, assim como na coordenação do Trabalho de Conclusão de Curso (TCC), propiciaram que as condutas adotadas fossem embasadas em observações que não se resumiram a uma única experiência em campo, tampouco ficaram restritas ao escopo da disciplina de Metodologia do Projeto.

Por consequência, adverte-se que a organização pedagógica do curso em questão seguramente foi um fator de influência para a evolução das novas abordagens. O formato do seu projeto pedagógico proporciona a flexibilidade de planejamento, a integração das unidades curriculares e dos professores em atividades conjuntas, aspectos que favoreceram a amplitude de associações de conceitos e o enriquecimento das percepções sobre o uso das ferramentas. Portanto, a utilização das estratégias aqui propostas em outros ambientes acadêmicos poderá ser facilitada - ou prejudicada pelas condições definidas no Projeto Pedagógico do Curso. Certamente a abordagem sistêmica do conhecimento projetual será menos árdua se o projeto pedagógico for 
concebido com uma intenção integradora, como é o caso do curso de Design de Moda da UEL.

Acredita-se que o potencial do Diagrama REC reside em sua utilização como facilitador da gestão de informações e da organização do raciocínio de modo flexível, permitindo a integração de estratégias metodológicas de acordo com cada projeto. Logo, ainda que o diagrama tenha seu uso coordenado com o Mapa de Categorias Expressivas, ambos podem ser utilizados de modo independente, mantendo a autonomia para agregar outras ferramentas, conforme o foco das ações investigativas do projeto. Esta flexibilidade facilita a aplicação do instrumental em outros ambientes acadêmicos, considerando que a decisão sobre as estratégias que deverão orientar um projeto de design depende, intrinsecamente, dos fatores peculiares ao contexto que o compreende. Os recursos e informações disponíveis, o grau de inovação exigido e o estilo cognitivo dos profissionais envolvidos são decisivos no direcionamento metodológico tomado.

Apesar das devidas ressalvas acerca de generalizações, as ações da presente pesquisa já evidenciaram alguns desdobramentos. O Diagrama REC e o Mapa de Categorias Expressivas continuam em uso no curso da UEL, agora com novos grupos de alunos, independentes da condução da presente pesquisadora.

Outro desdobramento se refere ao Mapa de Categorias Expressivas (MCE). Por meio das referências aos elementos sensórios, a ferramenta criou pontes cognitivas entre a síntese imagética e a sintaxe da forma, as quais foram além da informação estética. Por esse motivo, o MCE e os estudos gráficos do "espaço de design" foram adotados pelos alunos como documentos de síntese, para discussão entre os membros do grupo de trabalho e as interlocuções com os professores na depuração e consolidação do projeto. Assim, a antiga ficha-síntese foi substituída naturalmente pelos estudantes.

Em face à pronta assimilação e aos efeitos positivos creditados ao instrumental proposto, o Diagrama REC encontra-se, atualmente, em adaptação para propostas mais lúdicas de utilização. Conferindo-Ihe maior caráter interativo para a conexão com outras ferramentas complementares, o propósito é elaborar um material didático que integre outras ferramentas, elaboradas pela presente pesquisadora a partir da prática docente e das contribuições do projeto Incubadora de Novas Ideias. 
Em suma, sob o rumo da aprendizagem significativa, da gestão sistêmica do projeto e do pensamento visual, acredita-se ter avançado na busca por melhores práticas educacionais para o desenvolvimento do raciocínio projetual entre estudantes de Design de Moda, contribuindo para a ampliação do conhecimento a respeito das metodologias de projeto neste campo. Por outro lado, abre-se uma gama de futuras linhas de investigações a serem exploradas, tanto na aplicação do instrumental proposto com estudantes de outras áreas do Design, como no aprofundamento de estudos pedagógicos que amparem a utilização em outros ambientes acadêmicos de design de moda. 


\section{REFERÊNCIAS}

ALENCAR, Eunice M.L. Soriano de Alencar; FLEITH, Denise de Souza. Contribuições teóricas recentes ao estudo da criatividade. Psicologia, Teoria e Pesquisa [online]. v. 19, n.1, pp.1-8, 2003. Disponível em: <http://dx.doi.org/10.1590/S010237722003000100002>. Acesso em: 23 maio 2014.

ANDRÉ, Marli Elisa Dalmazo Afonso. Etnografia da Prática Escolar. Campinas SP: Papirus, 2005.

ANASTASIOU, Léa das Graças Camargos. Ensinar, aprender, apreender e processos de ensinagem. In: ANASTASIOU, Léa das Graças Camargos; ALVES, Leonir Pessate. (Orgs.) Processos de ensinagem na universidade: pressupostos para estratégias de trabalho e aula. Joinville SC: UNIVILLE, 2012a. p.17-44.

ANASTASIOU, Lea das Graças; ALVES, Leonir A. Estratégias de ensinagem. In: ANASTASIOU, Léa das Graças Camargos; ALVES, Leonir Pessate. (Orgs.) Processos de ensinagem na universidade: pressupostos para estratégias de trabalho e aula. Joinville SC: UNIVILLE, 2012c. p.75-107

- Grade e matriz curricular: conversas em torno de um desafio presente no ensino superior. In: FREITAS, Ana Lúcia Souza de et al. (Orgs.). Capacitação docente: um movimento que se faz compromisso. Porto Alegre: EDIPUCRS, 2010, p.181 - 200.

. Da visão de ciência à organização curricular. In: ANASTASIOU, Léa das Graças Camargos; ALVES, Leonir Pessate. (Orgs.) Processos de ensinagem na universidade: pressupostos para estratégias de trabalho e aula. Joinville SC: UNIVILLE, 2012b. p.4772.

ARNHEIM, Rudolf. Arte e percepção visual. São Paulo: Pioneira, 1980.

AUSUBEL, David P. Aquisição e retenção do conhecimento: uma perspectiva cognitiva. Lisboa: Plátano, 2003.

BARBISAN, Leci. O conceito de enunciação em Benveniste e Ducrot. Letras, n. 33, p. 23-35, 2006.

BARNARD, Malcom. Moda e comunicação. Rio de Janeiro, Rocco, 2003.

BAUMAN, Zygmunt. Modernidade Líquida. Rio de Janeiro: Zahar, 2001.

BARTHES, Roland. Sistema da moda. São Paulo: WMF Martins Fontes, 2009.

BATISTA, Marcia S. Diálogos (ex) intra muros: a teoria das cinco peles e uma trilogia interdisciplinar. In: BELLUZO, G., SILVA, J. (org.). DAMT: design, arte, moda e tecnologia. São Paulo: Rosari, 2011. v.1, n.7, p.219-255. 
BAXTER, Mike. Projeto de Produto: guia prático para desenvolvimento de novos produtos. São Paulo: Edgard Blücher, 1998.

BOMFIM, Gustavo. Amarante. Morfologia dos Objetos de Uso: uma contribuição para o desenvolvimento de uma teoria do design. In COUTO, R.M.; FARBIARZ, J.; NOVAES, L. (Orgs.) Gustavo Amarante Bomfim: uma coletânea. Rio de Janeiro: Rio Books, 2014 a. p. 23-32.

. Fundamentos de uma Teoria Transdisciplinar do Design: morfologia dos objetos de uso e sistemas de comunicação. In COUTO, R.M.; FARBIARZ, J.; NOVAES, L. (Orgs.) Gustavo Amarante Bomfim: uma coletânea. Rio de Janeiro: Rio Books, 2014 b. p. 35-50.

. Algumas Considerações sobre Teoria e Pedagogia do Design. In COUTO, R.M.; FARBIARZ, J.; NOVAES, L. (Orgs.) Gustavo Amarante Bomfim: uma coletânea. Rio de Janeiro: Rio Books, 2014 c. p. 57-72.

BONSIEPE, Gui. Design como prática de Projeto. São Paulo: Blucher, 2012.

BORDENAVE, Juan E. D. O que é comunicação. São Paulo: Brasiliense, 1996.

BÜRDEK, Bernhard. História, teoria e prática do design de produtos. Tradução de Freddy Van Camp. São Paulo: Edgard Blücher, 2006.

BUZAN, Tony; BUZAN, Buzan. The mind map book: how to use radiant thinking to maximize your brain's untapped potential. New York: Penguin Putnam, 1996.

CALDAS, Dario. Observatório de sinais: teoria e prática da pesquisa de tendências. Rio de Janeiro: SENAC Rio, 2004.

CAPRA, Fritjof. O ponto de mutação. 26. ed. São Paulo: Cultrix, 1986.

. A teia da vida: uma nova compreensão científica dos sistemas vivos. São

Paulo: Cultrix, 1996.

CARDOSO, Rafael. Design para um mundo complexo. São Paulo: Cosac Naify, 2012.

CASTILHO, Kathia. Moda e linguagem. São Paulo: Anhembi Morumbi, 2004.

COELHO, Luiz Antonio L.(org.). Conceitos-chave em design. Rio de Janeiro: PUC-Rio. Novas Ideias, 2008.

. Por uma Metodologia de Ideias. In: COELHO, Luiz Antonio L. (Org.). Design

Método. Rio de Janeiro: Ed. PUC Rio. Teresópolis: Novas Ideias, 2006. v. 1, Cap. 2, p.39 -53 .

. Adjetivando o método. In: II Seminário de Metodologia em Design: Ensino, Pesquisa e Projeto, 2. Recife. Anais... Recife: UFPE, 2008a. 
. Percebendo o Método. In: COUTO, Rita Maria; OLIVEIRA, Alfredo Jefferson (Orgs.). Formas do design: por uma metodologia interdisciplinar. Rio de Janeiro: $2 A B$, v. 1, c. 2, p. 28 - 51, 1999.

CONTANI, Miguel Luiz. A diferença de uma foto. Revista Signum. Londrina, PR, v.1, n.1, p. 15-3, 1998. Disponível em:

<http://www.uel.br/revistas/uel/index.php/signum/article/view/4479>. Acesso em: 20 out. de 2013.

CONTI, Giovanni M. Moda e Cultura de projeto industrial: hibridação entre saberes complexos. In: PIRES, Dorotéia (Org.) Design de moda: olhares diversos. Barueri, SP: Estação das Letras e Cores, 2008. v. 1, Parte II, p. 219-230.

CRANE, Diana. A moda e seu papel social: classe, gênero e identidade das roupas. São Paulo: SENAC, 2006.

CROSS, Nigel. Engineering design methods: strategies for product design. 3. ed. Chichester: Jonh Wily \& Sons, 2000.

DE CARLI, Ana Mery Sehbe. Moda no terceiro milênio: novas realidades, novos valores. In: De Carli, A. S.; MANFREDINI, Mercedes L. Moda em sintonia. Caxias do Sul, RS: Educs, 2010. p. 38-51.

DONDIS, Donis A. Sintaxe da linguagem visual. São Paulo: Martins Fontes, 1997.

EPPLER, Martin J.; BURKHARD, Remo A. Visual representations in knowledge management: framework and cases. Journal of knowledge management, v. 11, n. 4, p. 112-122, 2007.

EPPLER, Martin. What Is an effective knowledge visualization? Insights from a review of seminal concepts. In: MARCHESE, Francis T.; BANISSI, Ebad. Knowledge visualization currents. New York: Springer, 2013, p 3-12.

EPPLER, Martin; BURKHARD, Remo. Knowledge visualization: Towards a new discipline and its fields of applications. ICAWorking Paper, v. 2, 2004.

ERNER, Guillaume. Sociología de las tendencias. Barcelona: Gustavo Gilli, 2010.

FAGGIANI, Katia. O poder do design: da ostentação à emoção. Brasília: Thessaurus, 2006.

FAZENDA, Ivani Catarina Arantes. Integração e interdisciplinaridade no ensino brasileiro: efetividade ou ideologia. 6. ed. São Paulo: Loyola, 2002. . (org). Didática e interdisciplinaridade. 13. ed. Campinas: Papirus, 2008a. 2008b. Interdisciplinaridade: história, teoria e pesquisa. 15. ed. Campinas: Papirus, 
FIORINI, Veronica. Tendencias de consumo, innovación e identidad en la moda. Transformaciones en la enseñanza del diseño latino-americano. Cuadernos del centro de estudios de diseño y comunicación. Buenos Aires, n. 53, ano XVI, p. 79-89. Jul., 2015.

. Design de moda: abordagens conceituais e metodológicas. In: PIRES, D. (Org.) Design de moda: olhares diversos. Barueri, SP: Estação das Letras e Cores, 2008. v. 1, Parte III, p. 95-114.

FLICK, Uwe. Uma Introdução à pesquisa qualitativa. 2. ed. Porto Alegre, RS: Bookman, 2004.

FLUSSER, Vilém. O mundo codificado: por uma filosofia do design e da comunicação. São Paulo: Cosac Naify, 2007.

FRANZATO, Carlo; CELASCHI, Flaviano. Processo de metaprojeto para o desenvolvimento estratégico e a inovação das organizações. In: X P\&D Design Congresso Brasileiro de Pesquisa e Desenvolvimento em Design. Anais. São Luís: EDUFMA, 2012. p. 1-14.

GIDDENS, Anthony. As consequências da modernidade. São Paulo: UNESP, 1991.

GOMES FILHO, João. Gestalt do objeto: sistema de leitura visual da forma. São Paulo: Escrituras, 2003.

. Design do objeto: bases conceituais. São Paulo. Escrituras, 2006.

HALL, Stuart. A identidade cultural na pós-modernidade. Rio de Janeiro: DP\&A, 1999.

HERNANDIS, Bernabé. Desarrollo de uma metodologia sistêmica para el diseño de produtos industriales. Tesis Doctoral, Universidad Politécnica de Valencia. Valencia, 2003.

HERNANDIS, Bernabé. Diseño concurrente. In: MARTINS, R. F.; LINDEN, J. C. S (organizadores). Pelos caminhos do design: metodologia de projeto. Londrina: EDUEL, 2012. p. 327-396.

IIDA, Itiro. Ergonomia, projeto e produção. 2. ed. São Paulo: Edgard Blücher, 2005.

JONES, John C. Design methods. New York: John Wiley \& Sons, 1992.

JONES, Sue J. Fashion design. Londres: Laurence King Publishing e Central Saint Martins College of Art \& Design, 2005.

JORDAN, Patrick W. Designing pleasurable products: An introduction to the new human factors. London: CRC press, 2002.

KASPER, Humberto. O processo de pensamento sistêmico: um estudo das principais abordagens a partir de um quadro de referência proposto. Dissertação (Mestrado em 
Engenharia de Produção). Universidade Federal do Rio Grande do Sul, Programa de Pós-Graduação em Engenharia de Produção, Porto Alegre, 2000.

KNELLER, George F. Arte e Ciência da Criatividade. São Paulo: Ibrasa, 1976.

KRIPPENDORFF, Klaus. On the essential contexts of artifacts or on the proposition that "design in making sens (of things)". Design Issue. Cambridge, v. 5, n. 2, p. 9-38, Spring, 1989. Disponível em: <http://www.jstor.org/stable/1511512>. Acesso em: 30 out. 2013.

. Design centrado no usuário: uma necessidade cultural. Estudos em Design, Rio de Janeiro, v. 8, n. 3, set 2000, p. 87-98.

KRIPPENDORFF, Klaus; BUTTER, Reinhart. Semantics: Meanings and contexts of artifacts. In SCHIFFERSTEIN, Hendrik N. J.; HEKKERT, Paul (Ed.). Product experience. Elsevier, 2011. p. 1-25.

LAVILLE, Christian; DIONNE, Jean. A construção do saber: manual de metodologia da pesquisa em ciências humanas. Belo Horizonte: UFMG, 1999.

LAWSON, Bryan. Como arquitetos e designers pensam. São Paulo: Oficina de Textos, 2011.

LEBORG, Christian. Visual grammar. New York: Princeton Architectural Press, 2006.

LEIS, Hector Ricardo. Sobre o conceito de interdisciplinaridade. Cadernos de pesquisa interdisciplinar em ciências humanas. Florianópolis, no 73, Agosto 2005. Disponível em: $<$ http://www.periodicos.ufsc.br/index.php/cadernosdepesquisa/article/view/2176/44 55>. Acesso em: 01 jul. 2014.

LESSA, Washington Dias. Objetivos, desenvolvimento e síntese do projeto de design: a consciência do método. In WESTIN, Denise; COELHO, Luiz Antonio (orgs.). Estudo e prática de metodologia em design nos cursos de pós-graduação. Rio de Janeiro: Novas Ideias, 2011. p.18-54.

. Linguagem da forma/linguagem visual no âmbito do ensino de design: balizamentos teóricos; tópicos de pesquisa. Arcos Design, Rio de Janeiro, ESDI-UERJ, $\mathrm{n}$. 5, ano 4, n. 2, p. 69-91, dez. 2009.

LIMONAD, Ester. Reflexões sobre o espaço, o urbano e a urbanização. Geographia, Niterói, v. 1, n. 1, p. 71-91, 1999. Disponível em:

<http://www.uff.br/geographia/ojs/index.php/geographia/ issue/view/2>. Acesso em: 25 jul. 2014.

LIPOVETSKY, Gilles. 0 império do efêmero: a moda e seu destino nas sociedades modernas. São Paulo: Companhia das Letras, 1989.

LÖBACH, Bernd. Design industrial: bases para a configuração dos produtos industriais. São Paulo: Edgard Blücher, 2001. 
LUPTON, Ellen. Intuição, ação, criação. São Paulo: G. Gili, 2013.

LUPTON, Ellen; PHILIPS, Jennifer Cole. Novos fundamentos do design. São Paulo: Cosac Naify, 2008.

MACHADO. Irene. Um redirecionamento, o ponto de vista semiótico. 2003. Disponível em: <https://www.academia.edu/4216947/O_ponto_de_vista_semi\%C3\%B3tico>. Acesso em: 29 out. 2013.

MANZINI, Ezio. Cuando todos diseñan: uma introdución al diseño para la inovación social. Madrid: Experimenta, 2015.

MARTINS, Gilberto; THEÓPHILO Carlos. Metodologia da investigação científica para ciências sociais e aplicadas. São Paulo: Atlas, 2009.

MARTINS, Suzana. Ergonomia e moda: repensando a segunda pele. In: PIRES, D. (Org.) Design de Moda. Barueri, SP: Estação das Letras e Cores Editora, 2008. v. 1, Parte III, p. 319-336.

MBONU, Ezinma. Diseño de moda: creatividad y investigación. Barcelona: Promopress, 2014.

MELLO, Márcia Maria Couto. Modas, arquiteturas e cidades: interfaces, conexões e interferências. Tese (Doutorado em Arquitetura e Urbanismo) - Universidade Federal da Bahia. Salvador, 2011.

MILTON, Alex; RODGERS, Paul. Métodos de investigación para el diseño de produto. Barcelona: Blume, 2013.

MIOTTO, Thassiana de Almeida. O ensino da metodologia projetual no desenvolvimento de produtos de moda: um estudo de caso na universidade estadual de londrina. 2014. 110 f. Dissertação (Mestrado em Design), Faculdade de Arquitetura Artes e Comunicação, Universidade Estadual Paulista Julio de Mesquisa Filho, Bauru, 2014.

MONT'ALVÃO, Claudia R. Hedonomia, Ergonomia Afetiva: afinal, do que falamos? In: MONT'ALVÃO, Claudia; DAMAZIO, Vera (Ed.). Design ergonomia emoção. Mauad, 2008, pp. 18-29.

MONTEMEZZO, Maria Celeste de Fátima Sanches; SANTOS, João Eduardo Guarnetti dos. O papel do vestuário na interação homem - ambiente. IN: P\&D DESIGN, 5, Brasília. Anais. Rio de Janeiro: AEND-BR, 2002.

MONTEMEZZO, Maria Celeste de Fátima Sanches. Diretrizes Metodológicas para o projeto de produtos de moda no âmbito acadêmico. 110f. Dissertação (Mestrado Desenho Industrial). UNESP, Bauru, 2003.

MORAES, Dijon de. Metaprojeto: o design do design. São Paulo: Blucher, 2010. 
MORAES, Dijon De. Moda, design e complexidade. In: Dorotéia Pires (Org.) Design de Moda: olhares diversos. Barueri, SP: Estação das Letras e Cores Editora, 2008. v. 1, Parte II, p. 155-161.

MORIN, Edgar. A cabeça bem-feita: repensar a reforma, reformar o pensamento. Rio de Janeiro: Bertrand Brasil, 2003.

Os sete saberes necessários à educação do futuro. São Paulo: Cortez; Brasília, DF: UNESCO, 2001.

MOREIRA, Herivelto; CALEFFE, Luiz G. Metodologia da pesquisa: para o professor pesquisador. Rio de Janiro: Lamparina, 2008.

MOREIRA, Marco Antônio. Teorias de aprendizagem. São Paulo: EPU, 1999.

. Aprendizagem significativa crítica. In: MOREIRA, Marco Antonio et al. (Orgs.). Teoria da Aprendizagem Significativa - Contributos do III Encontro Internacional sobre Aprendizagem Significativa, Peniche, 2000, pp. 47-65.

Aprendizaje significativo: un concepto subyacente. In: Encuentro Internacional sobre el aprendizaje significativo, 1997, Burgos, España. Actas del Encuentro Internacional sobre el Aprendizaje Significativo. Burgos: Universidad de Burgos, 1997. p. 17-45.

Aprendizagem Significativa, Organizadores Prévios, Mapas Conceituais, Diagramas V e Unidades de Ensino Potencialmente Significativas. Porto Alegre, 2013. Material de apoio de curso. Pontifícia Universidade Católica do Paraná, 2013.

MOTTA, L.C. (2010). "Estruturas Semióticas do Conhecimento e Neurociência no Design Instrucional” In: NOJIMA, Vera Lucia; ALMEIDA JR., Licinio de (Org.). Design, comunicação e semiótica: estudo e pesquisa das relações transversais. Rio de Janeiro: 2AB Editora, v. 1, p. 60-76, 2010.

MOZOTA, B. Gestão do Design. São Paulo: Bookman, 2010.

MUNARI, Bruno. Design e comunicação visual. São Paulo: Martins, 2006.

NIEMEYER, Lucy. Elementos de semiótica aplicados ao design. Rio de Janeiro: 2AB, 2003.

NORMAN, Donald A. Design emocional: porque adoramos (ou detestamos) os objetos do dia-a-dia. Rio de Janeiro: Rocco, 2008.

NOVAK, Joseph D. Meaningful Learning: the essential fator for conceptual change in Limited or Inappropriate Propositional Hierarchies (LIPHs) leading to empowerment of learners. In MOREIRA, M.C. et al. (Orgs.). Teoria da aprendizagem significativa Contributos do III Encontro Internacional sobre aprendizagem significativa, Peniche, 2000, pp. 23-46.

OLIVEIRA, Sandra Ramalho. Imagem também se lê. São Paulo: Edições Rosari, 2005. 
. Moda também é texto. São Paulo: Rosari, 2007.

. Questões da moda, questões das "linguagens" visuais: Intertextualidades

possíveis. ModaPalavra e-Periódico, v. 4, n. 07, p.3-11. 2016.

ONO, Maristela. Design e cultura: sintonia essencial. Curitiba: Edição da Autora, 2006.

ONTORIA, Antonio; GOMEZ, Juan Pedro R.; LUQUE, A. Aprender com mapas mentales. Madrid: Narcea Ediciones, 2008.

OSGOOD, Charles. E.; SUCl, George. J.; TANNENBAUM, Percy. H. The measurement of meaning. Urbana: University of Illinois. 1957.

OSTROWER, Fayga. Criatividade e processos de criação. Petrópolis: Vozes, 1999.

PÁDUA, Gelson Luiz Daldegan. A epistemologia genética de Jean Piaget. Revista

FACEVV. 1을 Semestre, n. 2, p. 22-35, 2009.

PAZMINO, Ana Veronica Paz y Mino; COUTO, Rita Maria de Souza. Modelo de ensino de métodos de design de produtos. 2010. Rio de Janeiro, 2010. Tese (Doutorado em Design) -Pontifícia Universidade Católica do Rio de Janeiro, Departamento de Artes e Design.

PELIZZARI, Adriana et al. Teoria da aprendizagem significativa segundo Ausubel.

Revista PEC, Curitiba, v. 2, n. 1, p.37-42, jun. 2002.

PIGNATARI, Décio. 0 que é comunicação poética. Cotia: Ateliê, 2005, 66 p.

PIRES, Dorotéia Baduy. O desenvolvimento de produtos de moda: uma atividade multidisciplinar. IN: P\&D DESIGN, 6, 2004. São Paulo. Anais... São Paulo: AEND-BR, 2004.

PROCTOR, Tony. Creative problem solving for managers: developing skills for decision making and innovation. 2. Ed. New York: Routledge, 2005.

POZO, Juan Ignácio. Teorias cognitivas da aprendizagem. Porto Alegre: Artes Médicas, 1998.

PRESS, Mike; COOPER, Rachel. El diseño como experiencia. Barcelona: Gustavo Gili, 2009.

RECH, Sandra Regina. Moda: por um fio de qualidade. Florianópolis: Udesc, 2002.

REDIG, Joaquim. Design é Metodologia: procedimentos próprios do dia-a-dia do designer. In: COELHO, Luiz Antonio L. (Org.). Design método. Rio de Janeiro: Ed. PUC Rio; Teresópolis: Novas Ideias, 2006. v. 1, Cap. 12, p.169-177.

RENFREW, Elinor; RENFREW, Colin. Desenvolvendo uma coleção. Porto Alegre: Bookman, 2011. 176p. (Coleção Fundamentos de Design de Moda, v. 4). 
ROAM, Dan. Tu mundo en una servilleta. Barcelona: Planeta, 2010.

SALTZMAN, Andrea. O design vivo. In: PIRES, D. (Org.) Design de moda: olhares diversos. Barueri, SP: Estação das Letras e Cores Editora, 2008. v. 1, Parte III, p. 305318.

SALTZMAN, Andrea. Cuerpo. Vestido. Paisaje. IN: Cuadernos del Centro de Estudios de Diseño y Comunicación - El paisaje como referente de diseño y Paisaje Urbe. Buenos Aires, Año X, v. 30, p. 63-75. Nov. 2009.

SANCHES, Maria Celeste de Fátima. Design de Moda: sistematizar é fundamental. In: 3으 Colóquio de Moda,3, 2007. Belo Horizonte. Anais... Belo Horizonte: Faculdade Cimo, 2007.

SANCHES, Maria Celeste de Fátima. Projeto Integrador: uma reflexão para a evolução da sistematização de projeto no ensino de design de moda. Projética. Londrina, v.1, n.1, 101-114, dez. 2010.

SANCHES, Maria Celeste de Fátima et al. Bases para o ensino/aprendizagem de projeto no design de moda: conectando diretrizes didáticas e estratégias metodológicas.

ModaPalavra e-Periódico, Florianópolis, v. 9, n. 17, p. 119-144, 2016.

SANCHES, Maria Celeste de Fátima; HATADANI, Paula da Silva. A Prática interdisciplinar como diretriz do projeto pedagógico do curso de Design de Moda da Universidade Estadual de Londrina. Projetica, v. 5, n. 1, p. 209-224, 2014.

SANCHES, Maria Celeste de Fátima; MARTINS, Sérgio Regis Moreira. Projetando mensagens visuais: a contribuição das ferramentas de síntese imagética no design de moda. Estudos em Design, v. 23, n. 1, p. 108-117, 2015.

SANCHES, Maria Celeste de Fátima; ORTUÑO, Bernabé Hernandis; MARTINS, Sérgio R. Moreira. Fashion Design: The Project of the Intangible. Procedia Manufacturing, v. 3, p. 2311-2317, 2015.

SANCHES, Maria Celeste de Fátima. Uma análise da delimitação projetual no design de moda. In: VI CIPED Congresso Internacional de Pesquisa em Design, 2011, Lisboa, Portugal. Anais... VI Ciped, Congresso Internacional de Pesquisa em Design, Lisboa: CIAUD, 2011.

Projetando Moda: diretrizes para a concepção de produtos - In: Dorotéia Pires (Org.) Design de moda: olhares diversos. Barueri, SP: Estação das Letras e Cores Editora, 2008. v.1, Cap. 9, p. 289-301

Projetando o intangível: as ferramentas da linguagem visual no design de moda. In: MARTINS, R. F. F; LINDEN, J. C. S (orgs.). Pelos caminhos do design: metodologia de projeto. Londrina: EDUEL, 2012. p. 395-416.

SEIVEWRIGHT, Simon. Diseño e investigación. Barcelona: Gustavo Gili, 2013. 
Industrial). Universidade Estadual Paulista. Faculdade de Arquitetura, Artes e Comunicação, Bauru, 2006.

SANTAELLA, Lúcia. O que é semiótica. São Paulo: Brasiliense, 1990.

SCHÖN, Donald A. Educando o profissional reflexivo: um novo design para o ensino e a aprendizagem. Porto Alegre: Artmed, 2000.

SIMÓN, Gabriel. Diseño, artefacto y cultura material. Artigo do Foroalfa. [on-line]. México (DF), julho, 2013. Disponível em: <http://foroalfa.org/articulos/disenoartefacto-y-cultura-material>. Acesso em: 01 ago. 2014.

SORGER, Richard; UDALE, Jenny. Fundamentos de design de moda. Porto Alegre: Bookman, 2009.

SOUZA, Patrícia M.; MENEZES, Marizilda. Estratégias construtivas para a configuração do produto de moda. Projética. Londrina, v.2, n.1, p. 82-94, jun., 2011. Disponível em: <http://www.uel.br/revistas/uel/index.php/projetica/index>. Acesso em: 01 abr. 2014

SOUZA, Patrícia e Mello. A moulage, a inovação formal e a nova arquitetura do corpo. In: PIRES, D. (Org.) Design de moda: olhares diversos. Barueri, SP: Estação das Letras e Cores, 2008. v. 1, Parte III, p. 337-345.

. A modelagem tridimensional como implemento do processo de desenvolvimento do produto de moda. Dissertação (Mestrado em Desenho

SVENDSEN, Lars. Moda: uma filosofia. Rio de Janeiro: Zahar, 2010.

VALENTE, Silza Maria Pazello. Parâmetros curriculares e avaliação nas perspectivas do estado e da escola. 2002. Tese (Doutorado em Educação) - Universidade Estadual Paulista, Marília, 2014.

VAN DER LINDEN, Júlio Carlos de Souza; LACERDA, André. P. Metodologia projetual em tempos de complexidade. In: MARTINS, R. F. e VAN DER LINDEN, J. C. (Orgs). Pelos caminhos do design: metodologia de projeto. Londrina: EDUEL, 2012. p. 83-149.

VASCONCELLOS, Maria José Esteves. Pensamento sistêmico: o novo paradigma da ciência. Campinas-SP: Papirus, 2009.

VASCONCELOS, Clara; PRAIA, João Félix; ALMEIDA, Leandro S. Teorias de aprendizagem e o ensino/aprendizagem das ciências: da instrução à aprendizagem. Psicologia Escolar e Educacional, v. 7, n. 1, p. 11-19, 2003.

VASSÃO, Caio Adorno. Metadesign: ferramentas, estratégias e ética para a complexidade. São Paulo: Blucher, 2010.

TREPTOW, Doris. Inventando moda: planejamento de coleção. São Paulo: Edição da Autora, 2013. 
TSCHIMMEL, Katja. O Pensamento Criativo em Design: reflexões acerca da formação do designer. In: Congresso Internacional Use(r) Design. [CD-Rom] Lisboa: CPD. Disponível em:

<http://www.crearmundos.net/primeros/artigo\%20katja\%20o_pensamento_criativo_ em_design.htm>. Acesso em 30 out. 2012.

WONG, Wucius. Princípios de forma e desenho. São Paulo: Martins Fontes, 1998.

THIOLLENT, Michel. Metodologia da pesquisa-ação. São Paulo: Cortez, 1996.

TRIPP, David. Pesquisa-ação: uma introdução metodológica. Educação e pesquisa, v. 31, n. 3, p. 443-466, 2005.

ZEICHNER, Kenneth M.; DINIZ-PEREIRA, Júlio Emílio. Pesquisa dos educadores e formação docente voltada para a transformação social. Cadernos de pesquisa, v. $35, \mathrm{n}$. 125, p. 63-80, 2005.

Fontes das imagens internet:

LEVEZA DO SER. Liquidação Inverno 2016. Disponível em:

<https://www.facebook.com/vistaseeflua/?fref=ts>. Acesso em: 15 mai. 2016.

WEDDING DRESSES STYLE. Atelier Versace Colorful Bridal Gowns. Disponível em: <http://www.weddingdressesstyle.com/atelier-versace-colorful-bridal-gowns/>. Acesso em: 01 mar. 2012.

Fontes dos dados estatísticos sobre cursos superiores de Design de Moda:

Brasil. Ministério da Educação (MEC). Instituições de Educação Superior e Cursos Cadastrados. Disponível em: <http://emec.mec.gov.br/emec/nova\#simples>. Acesso em: 01 dez. 2015. 


\section{APÊNDICE A}

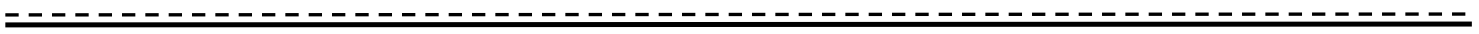

TABELA DE AVALIAÇÃO DE ALTERNATIVAS

\begin{tabular}{|l|l|l|l|l|l|l|l|l|l|}
\hline Objetivo & & A1 & A2 & A3 & A4 & A5 & $\cdots$ & Falta algo? Ajustes? \\
\hline & & & & & & & & \\
\hline & & & & & & & & \\
\hline & & & & & & & & \\
\hline & & & & & & & & \\
\hline & & & & & & & & \\
\hline & & & & & & & & \\
\hline & & & & & & & & \\
\hline & & & & & & & & \\
\hline & & & & & & & & \\
\hline & & & & & & & & \\
\hline & & & & & & & & \\
\hline & & & & & & & & \\
\hline
\end{tabular}

*VALORES: ++ (atende completamente); + (atende parcialmente); 0 (não é perceptível); - (não atende)

\section{DIAGRAMA DE OBJETIVOS EM FLUXO}

TECNOLOGIA $\leftrightarrow$ UTILIDADE $\leftrightarrow$ ADAPTAÇÃO $\leftrightarrow$ PERCEPÇÃO $\leftrightarrow$ INFORMAÇÃO

SUBSISTEMA FUNCIONAL SUBSISTEMA ERGONÔMICO SUBSISTEMA FORMAL

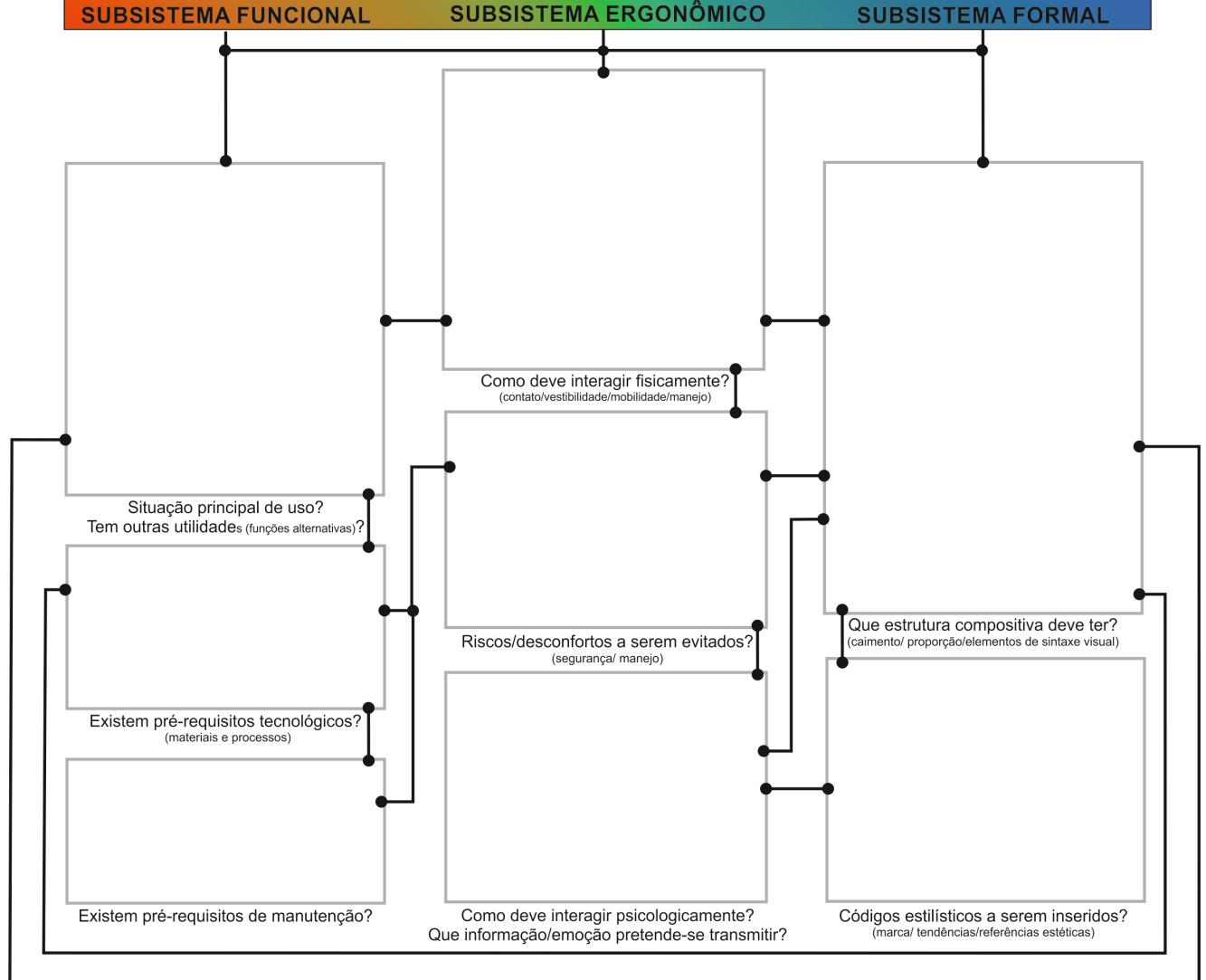




\section{APÊNDICE B}

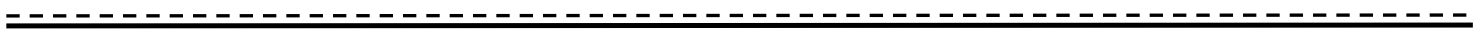

Protocolo de observação participante. INTERAÇÃO 3 - Pesquisadora: Mạ Celeste Sanches

Dia da observação: $/ 2015$ Local da Observação: UEL (segunda série)

Duração da Observação: horas

Objetivo: Características do grupo: 29 alunos do

垈
Bacharelado em Design de Moda (UEL) Disciplina de Metodologia do Projeto-

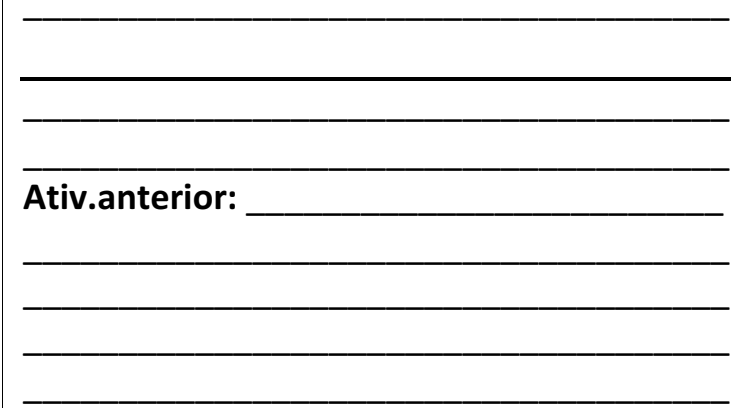
Conh. Prévio/ âncoras:

Anotações descritivas

Formato da atividade:

Conteúdos:

Procedimentos e Ferramentas: 


\section{APÊNDICE C}

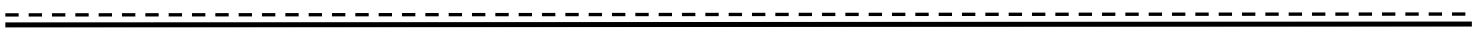

\begin{tabular}{|c|c|c|}
\hline DIFICULDADE & AUTOAVALIAÇÃO DOS ESTUDANTES & AVALIAÇÃO DOS PARES \\
\hline TRANSFORMADOR & & \\
\hline $\begin{array}{l}\text { Desvencilhar-se de } \\
\text { uma ideia } \\
\text { preconcebida } \\
\text { Estimulação do } \\
\text { pensamento } \\
\text { divergente/ } \\
\text { irradiante }\end{array}$ & $\begin{array}{l}\text { - Ajudou a gerar várias } \\
\text { possibilidades (ideias de } \\
\text { solução). } \\
\text { - Agregar a experimentação } \\
\text { tridimensional da forma e das } \\
\text { tecnologias (material e técnicas } \\
\text { de confecção) ajudou a ampliar } \\
\text { as possibilidades (sair da ideia } \\
\text { predefinida). }\end{array}$ & $\begin{array}{l}\text { - Divergência: exploração mais ampla } \\
\text { e diversificada das análises do } \\
\text { problema. } \\
\text { - Sintaxe visual ampliada: } \\
\text { desdobramento de linguagem em } \\
\text { coleção; diversificação de propostas } \\
\text { formais. }\end{array}$ \\
\hline $\begin{array}{l}\frac{\text { Transpor as }}{\text { informações p/ a }} \\
\frac{\text { síntese de objetivos }}{\text { Visão panorâmica }} \\
\text { integrada à síntese: } \\
\text { convergência } \\
\text { Gestão sistêmica da } \\
\text { informação } \\
\text { Reflexão na ação: } \\
\text { autonomia }\end{array}$ & $\begin{array}{l}\text { - Facilitou a identificação das } \\
\text { necessidades do público e a } \\
\text { "visualização" dos objetivos } \\
\text { coerentes. } \\
\text { - Proporcionou a visão do } \\
\text { conjunto e ajudou a conectar os } \\
\text { objetivos (utilidade, ergonomia } \\
\text { e linguagem). } \\
\text { - Facilitou a organização do } \\
\text { pensamento. }\end{array}$ & $\begin{array}{l}\text { - Convergência: coerência e foco; } \\
\text { maior qualidade de síntese. } \\
\text { - Autonomia: liberdade para a tomada } \\
\text { de decisões. } \\
\text { - Gestão sistêmica da informação: } \\
\text { visualização das conexões entre as } \\
\text { informações e identificação de } \\
\text { lacunas na investigação. }\end{array}$ \\
\hline $\begin{array}{l}\text { Integrar os objetivos } \\
\text { na materialização do } \\
\text { projeto } \\
\text { Gestão sistêmica da } \\
\text { informação } \\
\text { Experimentação } \\
\text { integrada à } \\
\text { delimitação } \\
\text { Interação: } \\
\text { problema-solução } \\
\text { Consciência dos } \\
\text { ciclos de análise, } \\
\text { síntese e avaliação } \\
\text { Reflexão na ação: } \\
\text { manutenção de foco }\end{array}$ & $\begin{array}{l}\text { - Auxiliou a gestão do processo } \\
\text { do inicio ao fim (manteve o } \\
\text { foco). } \\
\text { - Facilitou a expressão daquilo } \\
\text { que se quer transmitir no } \\
\text { produto; proporcionou a visão } \\
\text { de como cada parte se relaciona } \\
\text { com o todo (análise e síntese). } \\
\text { - Proporcionou a visão em } \\
\text { conjunto e ajudou a conectar os } \\
\text { objetivos (utilidade, ergonomia } \\
\text { e linguagem). } \\
\text { - O desenho do corpo agregado à } \\
\text { ferramenta ajudou a delimitar } \\
\text { melhor as necessidades e a } \\
\text { perceber a "forma" do produto. } \\
\text { - Pesquisa e geração caminharam } \\
\text { juntas. }\end{array}$ & $\begin{array}{l}\text { - Interação forma e corpo: a } \\
\text { representação do corpo na } \\
\text { ferramenta potencializou as } \\
\text { conexões entre os subsistemas e o } \\
\text { entendimento dos delimitadores da } \\
\text { forma; } \\
\text { - Experimentação: modelagem como } \\
\text { meio para estudar e entender os } \\
\text { objetivos do produto. Conectou a } \\
\text { percepção entre síntese imagética, } \\
\text { forma tridimensional e modelagem } \\
\text { plana. } \\
\text { Com o MCE notou-se que os alunos, } \\
\text { além da linguagem, vinculavam as } \\
\text { sínteses visuais e sensórias com } \\
\text { aspectos ergonômicos e } \\
\text { operacionais. }\end{array}$ \\
\hline $\begin{array}{l}\frac{\text { Transpor sínteses }}{\text { imagéticas } \mathrm{p} /} \\
\frac{\text { configuração }}{\text { tridimensional dos }} \\
\text { produtos } \\
\text { Pontes cognitivas } \\
\text { para a síntese de } \\
\text { conceitos formais: }\end{array}$ & $\begin{array}{l}\text { - Ajudou a "passar" os elementos } \\
\text { da imagem para a configuração } \\
\text { do produto. *(com maior } \\
\text { velocidade) }\end{array}$ & $\begin{array}{l}\text { - Otimização da síntese imagética: } \\
\text { mais facilidade e agilidade para } \\
\text { interpretação de referências e } \\
\text { extração de elementos de forma. } \\
\text { - Coerência entre a síntese da forma } \\
\text { e o pensamento expressivo / } \\
\text { linguagem. }\end{array}$ \\
\hline
\end{tabular}




\begin{tabular}{|c|c|c|}
\hline $\begin{array}{l}\text { elementos sensórios } \\
\text { e experimentação } \\
\text { Interação: } \\
\text { problema-solução } \\
\text { Experimentação } \\
\text { integrada à } \\
\text { investigação }\end{array}$ & & $\begin{array}{l}\text { - Os elementos sensórios do MCE, } \\
\text { principalmente o gesto, facilitam a } \\
\text { transposição da delimitação } \\
\text { conceitual para a forma } \\
\text { tridimensional. } \\
\text { - Experimentação: modelagem como } \\
\text { meio para estudar e entender os } \\
\text { objetivos do produto. Conectou a } \\
\text { percepção entre síntese imagética, } \\
\text { forma trid. e modelagem plana. }\end{array}$ \\
\hline $\begin{array}{l}\frac{\text { Selecionar e }}{\text { organizar as }} \\
\frac{\text { informações }}{\text { pesquisadas }} \\
\text { Gestão sistêmica da } \\
\text { informação } \\
\text { Autonomia }\end{array}$ & $\begin{array}{l}\text { - Facilitou a identificação das } \\
\text { necessidades do público e a } \\
\text { "visualização" dos objetivos } \\
\text { coerentes. } \\
\text { - Auxiliou a ampliar os pontos de } \\
\text { vista sobre o problema (visão } \\
\text { sistêmica) e depois a afunilar, } \\
\text { manter o foco. }\end{array}$ & $\begin{array}{l}\text { - Gestão sistêmica da informação: } \\
\text { visualização das conexões entre as } \\
\text { informações e identificação de } \\
\text { lacunas na investigação. } \\
\text { - Os alunos decidem quando e como } \\
\text { realimentar as informações e buscar } \\
\text { ajuda dos professores. }\end{array}$ \\
\hline $\begin{array}{l}\text { Selecionar a melhor } \\
\text { ideia } \\
\text { Reflexão na ação: } \\
\text { decisão } \\
\text { Reflexão sobre a } \\
\text { ação: propriedade } \\
\text { Consciência dos } \\
\text { ciclos de análise, } \\
\text { síntese e avaliação }\end{array}$ & - Serviu como guia para decidir. & $\begin{array}{l}\text { - Propriedade: autoavaliação da } \\
\text { trajetória projetual e apropriação } \\
\text { das estratégias para organizá-la. } \\
\text { - "Fazer" mais consciente e } \\
\text { autônomo: procuram os professores } \\
\text { para discutir questões já formuladas. } \\
\text { - Autonomia: liberdade e segurança } \\
\text { para a tomada de decisões. }\end{array}$ \\
\hline $\begin{array}{l}\text { Seguir metodologia } \\
\text { Metaprojeto } \\
\text { Reflexão sobre a } \\
\text { ação: propriedade } \\
\text { Gestão sistêmica do } \\
\text { processo } \\
\text { Conexão afetiva } \\
\text { Consciência dos } \\
\text { ciclos de análise, } \\
\text { síntese e avaliação }\end{array}$ & $\begin{array}{l}\text { - Ajudou na percepção da } \\
\text { evolução do próprio raciocínio } \\
\text { projetual (no projeto e na } \\
\text { disciplina). } \\
\text { - Facilitou a organização do } \\
\text { pensamento. } \\
\text { - Auxiliou a gestão do processo do } \\
\text { inicio ao fim (manteve o foco). }\end{array}$ & $\begin{array}{l}\text { - Prática reflexiva: autocrítica e } \\
\text { autorregulação - percepção do } \\
\text { próprio processo projetual. } \\
\text { - Propriedade: autoavaliação da } \\
\text { trajetória projetual e apropriação } \\
\text { das estratégias para organizá-la. } \\
\text { - Interação fácil (com as ferramentas } \\
\text { propostas), inclusive de modo } \\
\text { autônomo. } \\
\text { - Motivação: tranquilidade no } \\
\text { transcurso da atividade; afetividade } \\
\text { e satisfação com os resultados. }\end{array}$ \\
\hline $\begin{array}{l}\text { Seguir cronograma } \\
\text { Integração de } \\
\text { conhecimento e } \\
\text { ações- comunicação } \\
\text { Autonomia }\end{array}$ & $\begin{array}{l}\text { *Não houve depoimentos que } \\
\text { abordassem este tema. }\end{array}$ & $\begin{array}{l}\text { - Os alunos decidem quando e como } \\
\text { realimentar as informações e buscar } \\
\text { ajuda dos professores. } \\
\text { - Comunicação e gestão do trabalho } \\
\text { em equipe: DREC e MCE } \\
\text { potencializaram as discussões, os } \\
\text { mantendo conectados na } \\
\text { delimitação: auxilia distribuição de } \\
\text { tarefas/organização do tempo. }\end{array}$ \\
\hline
\end{tabular}

